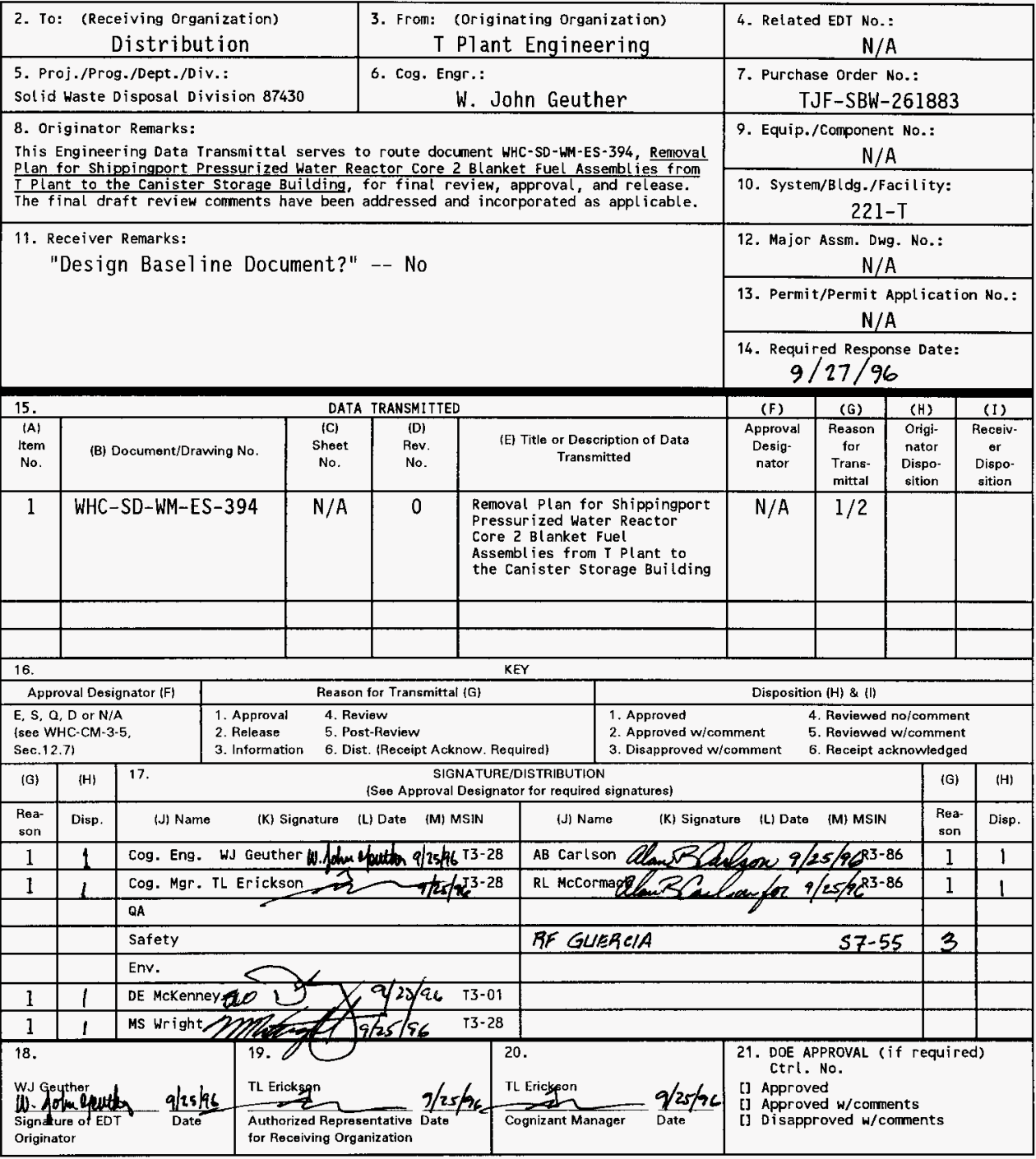




\begin{tabular}{|c|c|}
\hline BLOCK & TITLE \\
\hline$(1)^{*}$ & EDT \\
\hline (2) & To: (Receiving Organization) \\
\hline (3) & From: (Originating Organization) \\
\hline (4) & Related EDT No. \\
\hline (5) & Proj./Prog./Dept./Div. \\
\hline$(6)^{+}$ & Cognizant Engineer \\
\hline (7) & Purchase Order No. \\
\hline$(8)^{*}$ & Originator Remarks \\
\hline (9) & Equipment/Component No. \\
\hline (10) & System/BIdg./Facility \\
\hline (11) & Receiver Remarks \\
\hline$(12)$ & Major Assm. Dwg. No. \\
\hline$|13|$ & Permit/Permit Application No. \\
\hline$|14|$ & Required Response Date \\
\hline
\end{tabular}

(15)* Data Transmitted
(A)* Item Number
(B)* Document/Drawing No.
(C) * Sheet No.
(D)* Rev. No.
(E) Title or Description of Data Transmitted
$|F|^{*}$ Approval Designator
(G) Reason for Transmittal
(H) Originator Disposition
(I) Receiver Disposition

(16) Key

(17) Signature/Distribution
(G) Reason
(H) Disposition
(J) Name
(K]* Signature
(L) Date
(M) * MSIN

(18) Signature of EDT Originator

(19) Authorized Representative for Receiving Orgonization

(20) * Cognizant Manager

(21)* DOE Approval
- Pre-sssigned EDT number.

- Enter the individual's name, title of the organization, or entity (e.g.. Distribution) that the EDT is being transmitted to.

- Enter the title of the organization originating and transmitting the EDT.

- Enter EDT numbers which relate to the dats being transmitted.

- Enter the Project/Program/Department/Division title or Project/Program acronym or Project Number, Work Order Number or Organization Code.

- Enter the name of the individual identified as being responsible for coordinating disposition af the EDT.

- Enter related Purchase Order (P. O.) Number, if available.

- Enter special or additional comments concerning transmittal, or "Key" retrieval words may be entered.

- Enter equipment/component number of affected item, if appropriate.

- Enter applicable system, building or facility number, if appropriate.

- Enter special or additional comments concerning transmittal.

- Enter applicable drawing number of major assembly, if appropriate.

- Enter applicable permit or permit application number, if appropriate. - Enter the date a response is required from individuals identified in Block 17
(Signature/Distribution).

- Enter sequential number, beginning with 1 , of the information listed on EDT.

- Enter the unique identification number assigned to the document or drawing being transmitted.

- Enter the sheet number of the information being transmitted. If no sheet number, leave blank.

- Enter the revision number of the information boing transmitted. If no revision number, leave blank.

- Enter the title of the document or drawing or a brief description of the subject if no title is identifited.

- Enter the appropriate Approval Designator (Block 15). Also, indicate the appropriate approvsis for each item listed, i. 8, SO, ESQ, etc.

- Enter the appropriate code to identify the purpose of the data transmittal (see Block 16).

- Enter the appropriate disposition code (see Block 16 ).

- Enter the appropriate disposition code \{see Block 16 \}

- Number codes used in completion of Blocks $15(\mathrm{G}),(\mathrm{H})$, and (I), and $17(\mathrm{G}),(\mathrm{H})$ (Signature/Distribution).

- Enter the code of the reason for transmittal (Block 16)

- Enter the code for the disposition (Block 16).

- Enter the signature of the individual completing the Disposition $17(\mathrm{H})$ and the Transmittal.

- Obtain appropriate signature(s).

- Enter date signature is obtained.

- Enter MSIN. Note: If Distribution Sheet is used, show entire distribution fincluding that indicated on Page 1 of the EDT) on the Distribution Sheet.

- Enter the signature and date of the individual originating the EDT fentered prior to transmittal to Receiving Organization). If the EDT originator is the cognizant ongineer, sign both Blocks 17 and 18 .

- Enter the signature and date of the individual identified by the Receiving Organization as authorized to approve disposition of the EDT and acceptance of the data transmitted. as applicable.

- Enter the signature and date of the cognizant manager. IThis signature is authorization for release.1

- Enter DOE approval (it required) by signature or control number that tracks the approval to a signature, and indicate DOE action. 


\title{
Removal Plan for Shippingport Pressurized Water Reactor Core 2 Blanket Fuel Assemblies from T Plant to the Canister Storage Building
}

\author{
Prepared by: \\ Los Alamos Technical Associates, Inc. \\ (BNFL, Inc.) \\ Richland, WA \\ Prepared for: \\ Westinghouse Hanford Company, Richland, WA 99352 \\ U.S. Department of Energy Contract DE-AC06-87RL10930
}

\begin{tabular}{|c|c|}
\hline EDT: $\quad 615201$ & 2000 \\
\hline $\begin{array}{ll}\text { Org Code: } & 87430 \\
\text { B\&R Code: } & \text { EW3130020 }\end{array}$ & $\begin{array}{l}\text { Charge Code: } \\
\text { Total Pages: }\end{array}$ \\
\hline
\end{tabular}

Key Words: spent fuel, pressurized water reactor, transportation, dry storage, multiple canister overpack, Canister Storage Building, T Plant, canyon, vacuum drying

Abstract:

This document presents the current strategy and path forward for removal of the Shippingport Pressurized Water Reactor Core 2 blanket fuel assemblies from their existing storage configuration (wet storage within the $\mathrm{T} P($ ant canyon) and transport to the Canister Storage Building (designed and managed by the Spent Nuclear Fuels Division). The removal plan identifies all processes, equipment, facility interfaces, and documentation (safety, permitting, procedures, etc.) required to facilitate the PWR Core 2 assembly removal [from T Plant], transport [to the Canister storage Building], and storage at the Canister Storage Building. The plan also provides schedules, associated milestones, and cost estimates for all handling activities.

TRADEMARK DISCLAIMER. Reference herein to any specific comercial product, process, or service by trade name, trademark, manufacturer, or otherwise, does not necessarily constitute or imply its endorsement, recommendation, or favoring by the United States Government or any agency thereof or its contractors or subcontractors.

Printed in the United States of America. To obtain copies of this document, contact: WHC/BCS Document Control Services, P.O. Box 1970, Mailstop H6-08, Richland WA 99352, Phone (509) 372-2420; Fax (509) 376-4989.
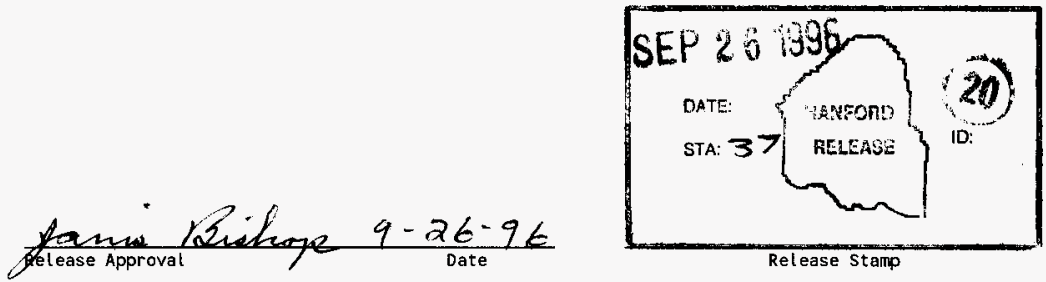

Release Stamp 
THIS PAGE INTENTIONALLY LEFT BLANK 
WHC-SD-WM-ES-394, Rev. 0

\section{REMOVAL PLAN FOR SHIPPINGPORT}

\section{PRESSURIZED WATER REACTOR CORE 2 BLANKET \\ FUEL ASSEMBLIES FROM T PLANT TO THE \\ CANISTER STORAGE BUILDING}

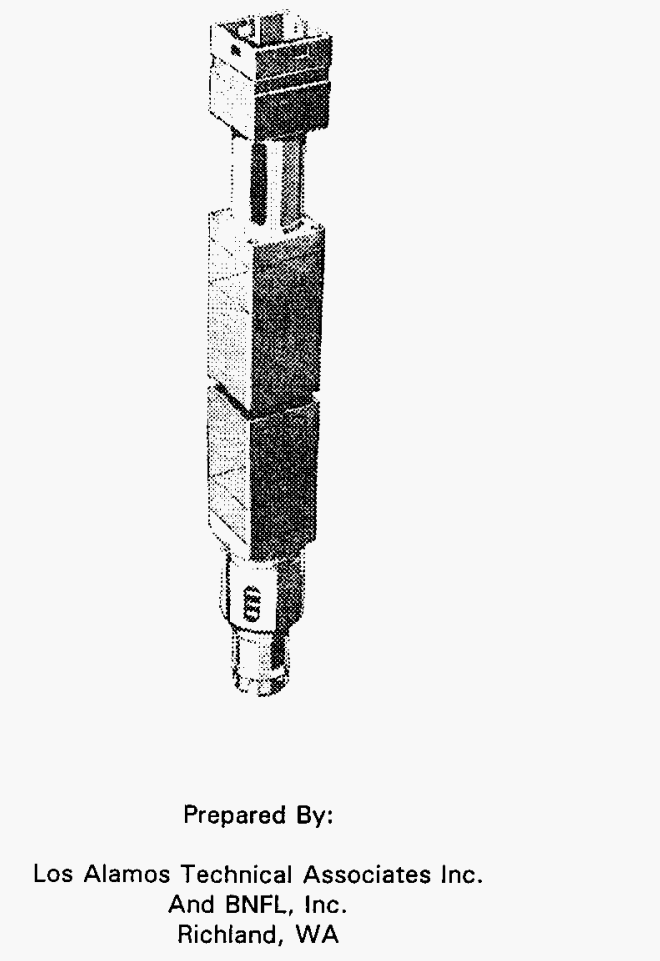

For:

WESTINGHOUSE HANFORD COMPANY

Richland, WA

September 1996 
WHC-SD-WM-ES-394, Rev. 0

This page intentionally left blank. 


\section{CONTENTS}

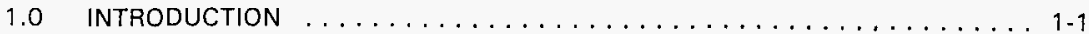

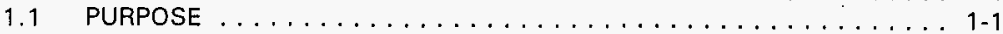

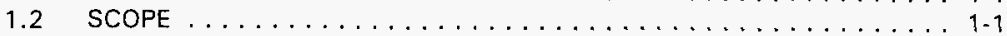

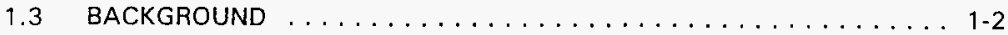

1.3.1 Requirement For Work Plan ... . . . . . . . . . . 1-2

1.3.2 Fuef Assembly History . . . . . . . . . . . . . 1-3

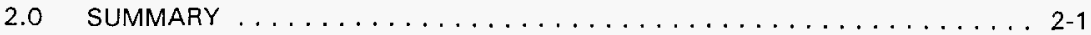

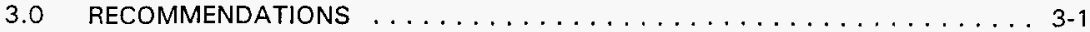

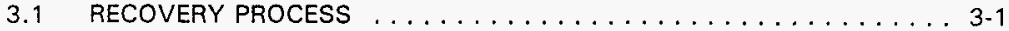

3.2 FUEL ASSEMBLY CONDITION, CRUD BUILD-UP, BOW, AND

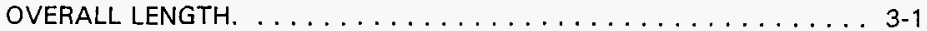

3.3 FUEL ASSEMBLY RADIOACTIVE DOSE ANALYSIS . . . . . . . . . $3-1$

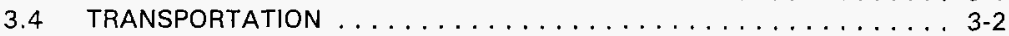

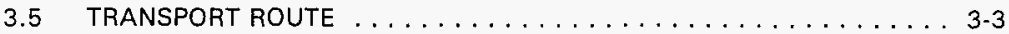

3.6 SAFETY BASIS DOCUMENTATION $\ldots \ldots \ldots \ldots \ldots \ldots \ldots \ldots \ldots$

3.6.1 T Plant Interim Safety Basis . . . . . . . . . . . . . . 3-3

3.6.2 Transportation and Packaging ................ $3-4$

3.6.3 Canister Storage Building . . . . . . . . . . . . . 3-4

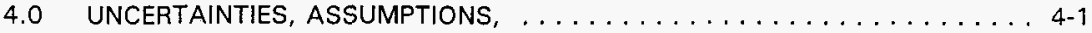

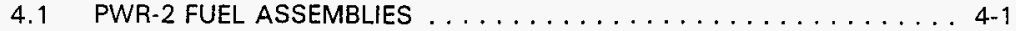

4.1 .1 Overall Structural Integrity . . . . . . . . . . . . . . 4-1

4.1 .2 Fuel Cladding ...................... 4 4-2

4.1 .3 Fuel Bow . . . . . . . . . . . . . . . . . . . . . 4 . 2

4.1 .4 Criticality ....................... 4 4-2

4.1 .5 Crud Deposits . . . . . . . . . . . . . . . . 4-3

4.1 .6 Radiation Dose Rates ..................... . 4.4

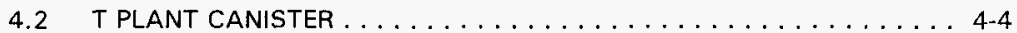

4.2.1 Canister Internal Dimensions ................ . . 4-4

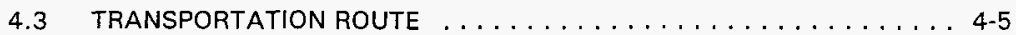

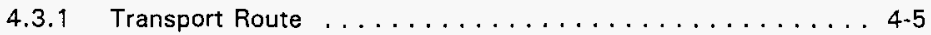

4.3.2 T Plant Access Road/Ramp ... . . . . . . . . . . 4 4-5

4.4 CANISTER STORAGE BUILDING $\ldots \ldots \ldots \ldots \ldots \ldots \ldots \ldots \ldots \ldots$

4.4.1 Acceptance Criteria . . . . . . . . . . . . . . . . . . . 4-6

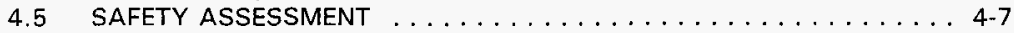

4.5 .1 Safety Basis . . . . . . . . . . . . . . . . . . 4-7

4.5 .2 Hazard Category . . . . . . . . . . . . . . . . 4-7

4.5.3 Transportation and Packaging ............... 4-8

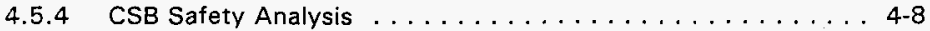

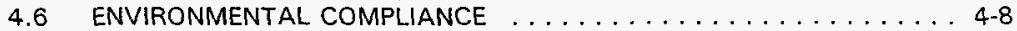

4.6.1 National Environmental Policy Act Review . . . . . . . . . . . . . 4-9

4.6.2 Permitting . . . . . . . . . . . . . . . . . . 4-9 
CONTENTS (Continued)

5.0 FUNCTIONAL ANALYSIS OF PWR-2 FUEL TRANSFER $\ldots \ldots \ldots \ldots \ldots \ldots$

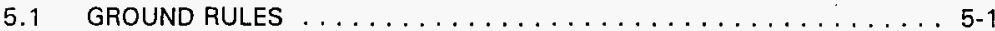

5.2 FUNCTIONAL REVIEW AREAS $\ldots \ldots \ldots \ldots \ldots \ldots \ldots \ldots \ldots$

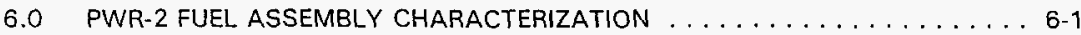

6.1 PWR CORE 2 BLANKET FUEL ASSEMBLIES $\ldots \ldots \ldots \ldots \ldots \ldots \ldots \ldots$

6.2 PWR-2 FUEL ASSEMBLY CONSTRUCTION $\ldots \ldots \ldots \ldots \ldots \ldots \ldots \ldots$

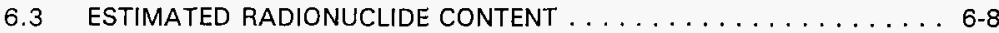

6.4 RADIATION LEVELS AND ESTIMATED HEAT OF DECAY . . . . . . . $6-9$

6.4 .1 WHC Dose Calculations . . . . . . . . . . . . . 6-9

6.4 .2 LATA Dose Calculations ................. . 6.10

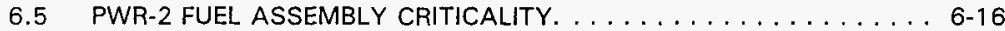

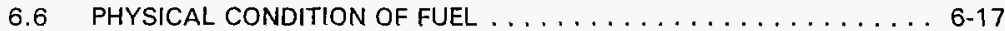

6.6.1 Condition of Fuel Cladding ................ 6-17

6.6 .2 Fuel Assembly Bow .................... 6-17

6.6.3 Confirmation of Dimensions ................. 6-18

6.6.4 Confirmation of Materials of Construction and Condition ... 6-18

6.6 .5 Plan Assumptions . . . . . . . . . . . . . . . 6-19

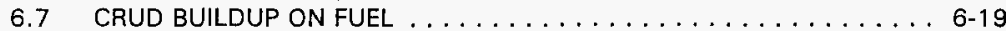

6.7.1 PWR-2 Fuel Assembly Interior Crud Characteristics. . . . . . . 6-20

6.7.2 Reactor Coolant Crud Characteristics . . . . . . . . . . . 6-20

6.7.3 Fuel Assembly Exterior Crud Deposits . . . . . . . . . . . . 6-22

6.7 .4 Crud Consequences ................... 6-22

6.8 CHARACTERIZATION DATA PACKAGE . . . . . . . . . $6-22$

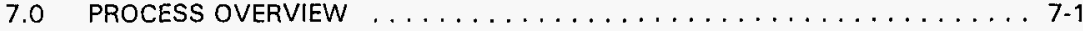

7.1 PWR-2 FUEL TRANSFER OPERATIONS $\ldots \ldots \ldots \ldots \ldots \ldots \ldots \ldots$

7.1.1 Documentation to Commence Operations ......... 7-1

7.1 .2 Training and Training Aids ............... 7-3

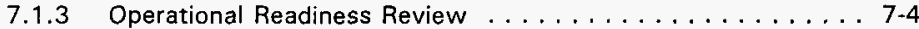

7.1 .4 Place Cask/Canister in T Plant . . . . . . . . . . . 7-4

7.1 .5 Prepare Cask/Canister . . . . . . . . . . . . . . . . 7-4

7.1.6 Remove Fuel From Storage Pool . . . . . . . . . . . . 7-5

7.1 .7 Insert Fuel into T Plant Canister . . . . . . . . . . 7-6

7.1 .8 Canister Shield Plug Insertion . . . . . . . . . . ... 7-9

7.1.9 Sealing The Canister Shield Plug . . . . . . . . . . . 7-9

7.1 .10 Vacuum Dry Canister . . . . . . . . . . . . . . 7-10

7.1.11 Fill T Plant Canister With Inert Gas . . . . . . . . . . . . . 7-10

7.1 .12 Clean Area ...................... 7-10

7.1 .13 Seal Cask ....................... 7-10

7.1.14 Confirm Cask is Suitable for Transportation . . . . . . . . 7-11

7.2 ALTERNATIVE RETRIEVAL OPTIONS .............. $7-11$

7.2.1 Option 1 - Elevate Cask and T Plant Canister . . . . . . . . . 7-11

7.2.2 Option 2 - Transfer T Plant Canister to Storage Pool . . . . . 7.12 


\section{CONTENTS (Continued)}

7.3 TRANSPORTATION TO CSB ................ 7-15

7.3.1 Transport Documentation . . . . . . . . . . . . 7-17

7.3.2 Proposed Transport Equipment . . . . . . . . . . . . 7-17

7.3.3 Transport Route . . . . . . . . . . . . . . . . 7-17

7.4 CANISTER STORAGE BUILDING - RECEIPT OF PWR-2 FUEL

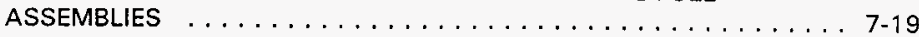

7.4.1 Canister Storage Building - Criteria for Acceptance . . . . . . . 7.19

7.4.2 CSB Documentation and Procedures . . . . . . . . . . . 7-21

7.4.3 Unloading and Storage of T Plant Canister in Canister Storage Building .......................... 7-22

7.4.4 Confirm Cask Cleanliness ................. 7-22

7.4.5 Insert New T Plant Canister Into Cask at Canister Storage Building.

8.0 EQUIPMENT AND FACILITIES $\ldots \ldots \ldots \ldots \ldots \ldots \ldots \ldots \ldots$

8.1 T PLANT EQUIPMENT AND LAYOUT $\ldots \ldots \ldots \ldots \ldots \ldots \ldots \ldots \ldots$

8.1 .1 Layout of T Plant . . . . . . . . . . . . . . . 8-1

8.1.2 PWR-2 Storage Pool and Equipment . . . . . . . . . . 8-4

8.1 .3 T Plant Cranage $\ldots \ldots \ldots \ldots \ldots \ldots \ldots \ldots \ldots . \ldots \ldots$. . . . . . . . . . . . . . . .

8.1 .4 Grapplers . . . . . . . . . . . . . . . . . . 8-8

8.2 T PLANT CANISTER . . . . . . . . . . . . . . . . $8-10$

8.2.1 K Basin Multiple Canister Overpack . . . . . . . . . . . 8 8-11

8.2.2 TPlant Canister ..................... 8-14

8.2.3 T Plant Canister/K Basin Multi-Canister Overpack Design

Variations ......................... 8-17

8.3 VACUUM DRYING EQUIPMENT $\ldots \ldots \ldots \ldots \ldots \ldots \ldots \ldots \ldots \ldots$

8.3.1 System Interfaces . . . . . . . . . . . . . . . 8 8 .19

8.3.2 Functional Requirements ................ 8-19

8.3.3 Physical Characteristics .................. 8-21

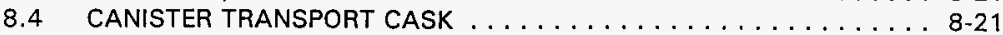

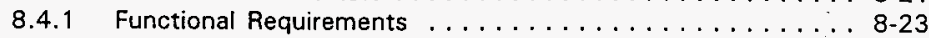

8.4 .2 Physical Characteristics ................... 8.23

8.4.3 Containment ...................... 8-23

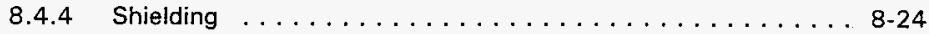

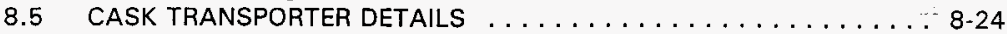

8.5.1 Transporter System . . . . . . . . . . . . . . . . 8-24

8.5.2 Transporter Interfaces . . . . . . . . . . . . . . 8-24

8.5.3 Functional Requirements ................. 8-27

8.6 CANISTER STORAGE BUILDING $\ldots \ldots \ldots \ldots \ldots \ldots \ldots \ldots \ldots \ldots$

8.7 DESIGN PACKAGE REQUIREMENTS $\ldots \ldots \ldots \ldots \ldots \ldots \ldots \ldots \ldots$

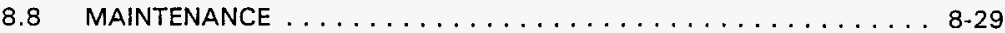

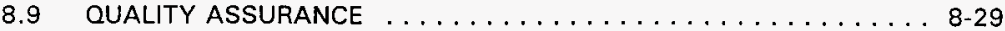

8.9.1 General Requirements . . . . . . . . . . . . . . . 8.29

8.9.2 Responsibility for Quality Assurance . . . . . . . . . . . . 8-29

8.9.3 Quality Assurance Requirements . . . . . . . . . . . . 8-29 
CONTENTS (Continued)

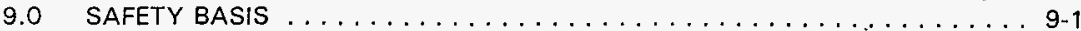

8.1 CURRENT STATUS OF SAFETY BASIS DOCUMENTATION $\ldots \ldots . . .9-1$

9.1.1 T Plant SABD Status. . . . . . . . . . . . . . . . 9-3

9.1.2 Canister Storage Building/K Basin Safety Authorization Basis

Documentation Status. . . . . . . . . . . . . . 9-3

9.2 UNREVIEWED SAFETY QUESTIONS DETERMINATION $\ldots \ldots \ldots \ldots \ldots .9-3$

9.2.1 T Plant Unreviewed Safety Question Determination ... . . . . 9-4

9.2.2 Canister Storage Building and Transportation/Packaging

Unreviewed Safety Question Determination . . . . . . . . . . 9-4

9.3 SAFETY ANALYSIS . . . . . . . . . . . . . . . . . $9-5$

9.3.1 T Plant Safety Analyses. . . . . . . . . . . . . . . . . . 9-5

9.3.2 Transportation and Packaging Safety Analysis . . . . . . . . 9-10

9.3.3 Canister Storage Building Safety Analysis. . . . . . . . . . . . . 9-14

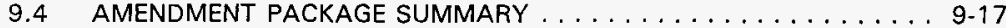

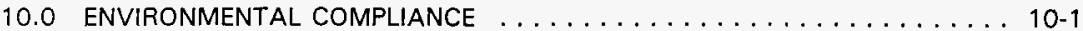

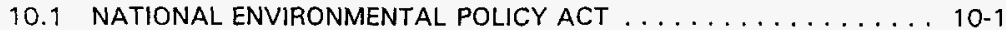

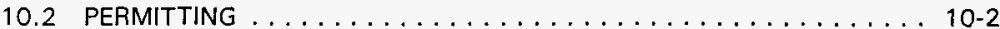

10.2.1 Resource Conservation Recovery Act/Dangerous Waste

Permitting Requirements . . . . . . . . . . . . 10-2

10.2.2 Air Permitting . . . . . . . . . . . . . . . . 10 10 2

10.2.3 Cultural Resources Review ............. 10-2

11.0 SAFEGUARDS AND ACCOUNTABILITY $\ldots \ldots \ldots \ldots \ldots \ldots \ldots \ldots \ldots$

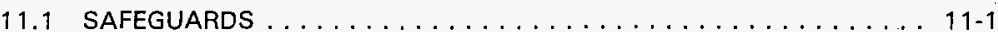

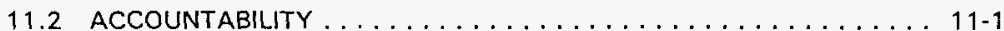

12.0 REMOVAL OF T Plant POOL WATER AND ION EXCHANGE COLUMN $\ldots \ldots$ 12-1

12.1 REMOVAL AND DISPOSAL OF STORAGE POOL WATER . . . . . . . 12-1

12.1.1 Storage Pool Draining Preparation ... . . . . . . . . 12-1

12.1.2 Storage Pool Water Transfer . . . . . . . . . . . . . 12-2

12.1.3 Tanker Truck Clearance . . . . . . . . . . . . . . . 12-2

12.2 REMOVAL AND DISPOSAL OF PWR-2 ION EXCHANGE COLUMN ... 12-2

12.2.1 PWR-2 Ion Exchange Column Description ........... 12-3

12.2.2 Ion Exchange Column Preparation . . . . . . . . . . . 12-3

12.2.3 Ion Exchange Column Transfer . . . . . . . . . . . . . 12-4

13.0 TRANSFER SCHEDULE $\ldots \ldots \ldots \ldots \ldots \ldots \ldots \ldots \ldots \ldots \ldots \ldots \ldots$

14.0 RETRIEVAL AND TRANSFER COST $\ldots \ldots \ldots \ldots \ldots \ldots \ldots \ldots \ldots \ldots$

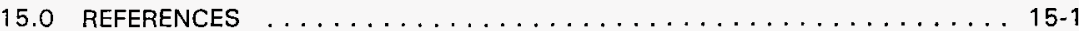




\section{LIST OF FIGURES}

5-1. PWR-2 Fuel Assembly Transfer Functional Review Areas $\ldots \ldots \ldots . \ldots$. . . . .

6-1. PWR-2 Fuel Assembly $\ldots \ldots \ldots \ldots \ldots \ldots \ldots \ldots \ldots \ldots \ldots \ldots \ldots$

6-2. PWR-2 Fuel Assembly Top Extension Bracket . . . . . . . . . . . 6-3

6-3. PWR-2 Fuel Assembly Fuel Cluster $\ldots \ldots \ldots \ldots \ldots \ldots \ldots \ldots$

6-4. PWR-2 Blanket Assembly Bottom Extension Bracket . . . . . . . . . . . 6-5

6-5. Single Unshielded PWR-2 Fue! Assembly Dose Rate Locations. . . . . . . . . 6-11

6-6. T Plant Canister and Four PWR-2 Fuel Assemblies Dose Rate Locations. . . . 6-12

6-7. Cask/Canister and Four PWR-2 Fuel Assemblies Dose Rate Locations. . . . . 6-13

7-1. T Plant PWR-2 Fuel Assembly Removal Process Flow Diagram . . . . . . . . 7-2

7-2. Elevation of PWR-2 Fuel Assembly Transfer . . . . . . . . . . . . . 7-7

7-3. Plan View of PWR-2 Fuel Assembly Transfer . . . . . . . . . . . . . . 7-8

7-4. Alternative Retrieval Option One (Elevation View) $\ldots \ldots \ldots \ldots \ldots$

7-5. Alternative Retrieval Option One (Plan View) $\ldots \ldots \ldots \ldots \ldots \ldots$. $\ldots \ldots$

7-6. Alternative Retrieval Option Two (Elevation View) $\ldots \ldots \ldots \ldots \ldots$ 7-16

7-7. Transfer Route for PWR-2 Fuel Assemblies from T Plant to CSB . . . . . . . 7-18

8-1. T Plant Complex Overview ..................... 8-2

8-2. T Plant Canyon Cross Section . . . . . . . . . . . . . . . 8-3

8-3. Typical PWR-2 Storage Rack ... . . . . . . . . . . . . 8-6

8-4. K Basin Welded Shielding Plug MCO Design . . . . . . . . . . . . . 8-12

8-5. K Basin Bolted Shielding Plug MCO Design . . . . . . . . . . . 8-13

8-6. Welded and Bolted Canister Design Differences . . . . . . . . . . 8-15

8-7. PWR-2 Assembly and Spacer Basket Arrangement Within a T Plant Canister. 8-18

8-9. Canister Transport Cask ... . . . . . . . . . . . . . . . 8-22

8-10. T Plant Tunnel Access Road . . . . . . . . . . . . . . . . . 8-25 


\section{LIST OF FIGURES (Continued)}

8-11. T Plant Tunnel Access Ramp Required Upgrades . . . . . . . . . . . 8-26

9-1. Existing and Proposed Safety Documentation . . . . . . . . . . . . 9-2

11-1. PWR-2 Fuel Assembly Identification Number Location. . . . . . . . . . 11-2

13-1. T Plant Fuel Assemblies Remova! Schedule (Following K Basin SNF Retrieval) 13-2

13-2. T Plant Fuel Assemblies Removal Schedule (Concurrent with K Basin SNF

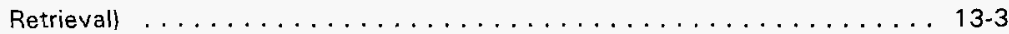




\section{LIST OF TABLES}

4-1. Assumed CSB/PWR-2 Fuel Assembly General Acceptance Criteria . . . . . . 4-6

5-1. PWR-2 Fuel Assembly Transfer Functional Performance Requirements . . . . 5-3

6-1. PWR-2 Fuel Assembly Construction Details . . . . . . . . . . . . 6-1

6-2. PWR-2 Fuel Assembly Radionuclide Activity and Decay Heat . . . . . . . 6. 6-7

6-3. PWR Stainless Steel Extensions Radionuclide Activity and Decay Heat . . . . 6-8

6-4. PWR-2 Fuel Assembly Actinides Mass . . . . . . . . . . . . . . 6-8

6-5. WHC PWR-2 Dose Rates ..................... 6 .9

6-6. LATA PWR-2 Dose Rates . . . . . . . . . . . . . . . 6-14

6-7. LATA PWR-2 Heat Decay . . . . . . . . . . . . . . . . . . 6-14

6-8. PWR-2 Fuel Assembly Criticality . . . . . . . . . . . . . $6-16$

6-9. LWBR Maximum Fuel Assembly Bow . . . . . . . . . . . . . . 6-17

6-10. PWR-2 Fuel Assembly Crud Compositions . . . . . . . . . . . . . 6-20

6-11. PWR-2 Coolant Crud Concentrations and Activity . . . . . . . . 6-21

7-1. Assumed CSB/PWR-2 Fuel Assembly Detailed Acceptance Criteria . . . . . 7-20

7-2. CSB External Contamination Limits . . . . . . . . . . . . . 7-21

8-1. T Plant Storage Pool Water Quality Limits . . . . . . . . . . . . 8-4

8-2. T Plant Storage Pool Water Characteristics As Sampled on . . . . . . . . 8-5

8-3. K Basin MCO Design Details . . . . . . . . . . . . . . . . 8-11

8-4. Design Forces for Cask Transporter Tiedown Attachments . . . . . . . . 8-28

9-1. T Plant ISB Addendum Evaluation Sheet, PWR-2 Operation . . . . . . . . . 9-6

9-2. Hazard Category Thresholds . . . . . . . . . . . . . . . . . 9-9

9-3. SARP Addendum Evaluation Sheet, PWR-2 Operation . . . . . . . . . . 9-12

9-4. CSB SAR Addendum Evaluation Sheet, PWR-2 Operation .......... 9-15 


\section{LIST OF TABLES (Continued)}

9-6. Estimated Cost and Time for PWR-2 Fuel Assembly Transfer Safety Basis Amendment Packages. . . . . . . . . . . . . . . . . . 9-17

12-1. PWR-2 Ion Exchange Column Information $\ldots \ldots \ldots \ldots \ldots \ldots$

14-1. Cost of PWR-2 Removal (Following K Basin SNF Retrieval) . . . . . . . . . 14-1

14-2. Fuel Assemblies Removal from T Plant - Cost Estimate . . . . . . . . . . . 14-2 


\section{LIST OF TERMS}

\begin{tabular}{|c|c|}
\hline ALARA & As Low As Reasonably Achievable \\
\hline ANSI & American National Standards Institute \\
\hline CCTV & Closed-Circuit Television \\
\hline CSB & Canister Storage Building \\
\hline CSER & Criticality Safety Evaluation Report \\
\hline$D \& D$ & Decommissioning and Decontamination \\
\hline DBA & Design Basis Accident \\
\hline Ecology & Washington State Department of Ecology \\
\hline DOE & U.S. Department of Energy \\
\hline DSC & Dry Shielded Canister \\
\hline EA & Environmental Assessment \\
\hline EBR & Experimental Breeder Reactor \\
\hline ECN & Engineering Change Notice \\
\hline ETF & Effluent Treatment Facility \\
\hline EIS & Environmental Impact Statement \\
\hline FEDAL & Failed fuel Element Detection And Location \\
\hline FFTF & Fast Flux Test Facility \\
\hline FONSI & Finding Of No Significant Impact \\
\hline HEPA & High Efficiency Particulate Air \\
\hline $\mathrm{HP}$ & Health Physics \\
\hline HSM & Horizontal Storage Module \\
\hline IAEA & International Atomic Energy Agency \\
\hline IOSR & Interim Operational Safety Requirements \\
\hline ISA & Interim Storage Area \\
\hline ISB & Interim Safety Basis \\
\hline ISC & Interim Storage Cask \\
\hline LAMPRE & Los Alamos Molten Plutonium Reactor Experiment \\
\hline LATA & Los Alamos Technical Associates \\
\hline LWBR & Light Water Breeder Reactor \\
\hline MCO & Multiple Canister Overpack \\
\hline MOU & Memorandum of Understanding \\
\hline MSB & Multiassembly Sealed Basket \\
\hline MWD & Megawatts day \\
\hline MTU & Metric Tons Uranium \\
\hline PNNL & Pacific Northwest National Laboratory \\
\hline NEPA & National Environmental Policy Act \\
\hline NOC & Notice of Construction \\
\hline NRC & Nuclear Regulatory Commission \\
\hline ORR & Operational Readiness Review \\
\hline PFP & Plutonium Finishing Plant \\
\hline PWR & Pressurized Water Reactor \\
\hline PWR-2 & Pressurized Water Reactor Core 2 \\
\hline$Q A$ & Quality Assurance \\
\hline QARD & Quality Assurance Requirements and Description \\
\hline RCRA & Resource Conservation and Recovery Act \\
\hline ROD & Record of Decision \\
\hline SAR & Safety Analysis Report \\
\hline
\end{tabular}




\section{LIST OF TERMS (continued)}

$\begin{array}{ll}\text { SARP } & \text { Safety Analysis Report for Packaging } \\ \text { SABD } & \text { Safety Authorization Basis Documentation } \\ \text { SCALE } & \text { Standardized Computer Analyses for Licensing Evaluation } \\ \text { SFD } & \text { Spent Nuclear Fuels Project Division } \\ \text { SNF } & \text { Spent Nuclear Fuel } \\ \text { SNFP } & \text { Spent Nuclear Fuel Project } \\ \text { SS } & \text { Stainless Steel } \\ \text { SWDD } & \text { Solid Waste Disposal Division } \\ \text { TID } & \text { Tamper Indicating Device } \\ \text { TSAR } & \text { Transportation Safety Analysis Requirements } \\ \text { TSR } & \text { Technical Safety Requirements } \\ \text { USO } & \text { Unreviewed Safety Question } \\ \text { USOE } & \text { Unreviewed Safety Question Evaluation } \\ \text { USOD } & \text { Unreviewed Safety Question Determination } \\ \text { VA } & \text { Vulnerability Assessment } \\ \text { VCC } & \text { Ventilated Concrete Cask } \\ \text { VSC } & \text { Ventilated Storage Cask } \\ \text { WHC } & \text { Westinghouse Hanford Company } \\ \text { WPD } & \text { Waste Programs Division } \\ \text { WSDH } & \text { Washington State Department of Health } \\ & \end{array}$

\section{LIST OF UNITS}

$\begin{array}{ll}\mathrm{m} & \text { meters } \\ \mathrm{ft} & \text { feet } \\ \mathrm{cm} & \text { centimeters } \\ \text { in } & \text { inches } \\ \mathrm{L} & \text { liters } \\ \mathrm{gal} & \text { gallons } \\ \mathrm{g} / \mathrm{cc} & \text { grams per cubic centimeters } \\ \mathrm{gpm} & \text { gallons per minute } \\ \mathrm{scc} / \mathrm{sec} & \text { standard cubic centimeters per second } \\ \mathrm{R} / \mathrm{hr} & \text { Roentgen per hour }\end{array}$




\subsection{INTRODUCTION}

\subsection{PURPOSE}

This document is a work plan for the removal of the Shippingport Pressurized Water Reactor Core 2 (PWR-2) blanket fuel assemblies from their current storage location in $T$ Plant for transportation of the assemblies to a designated storage area within the Canister Storage Building (CSB). The fuel assemblies are currently stored in underwater storage racks within a converted cell in the 221-T canyon.

\subsection{SCOPE}

The work plan identifies all processes, equipment, facilities, and documentation (safety, approvals, characterization, etc.) required to facilitate PWR-2 fuel assembly removal from T Plant and transportation to, and storage in, the CSB. The work plan also provides a schedule and cost estimate for all removal activities. Specifically, this plan includes:

- Identification of all facilities and equipment required to 1) transfer the PWR-2 fuel assemblies from underwater storage racks in T Plant and 2) contain, shield, and transport the fuel assemblies to CSB storage. The plan assumes that casks and transporters used for K Basin Spent Nuclear Fuel (SNF) retrieval will also be used to transport the PWR-2 fuel assemblies from T Plant to the CSB.

- Identification of changes to the existing T Plant and CSB safety basis, environmental, and permitting documentation to allow fuel transfer.

- Identification of operational requirements including processes, operational documentation (procedures, work plans, etc.), training, operational readiness reviews (ORRs), and start-up requirements, to recover the fuel and move it from T Plant for storage at the CSB.

- Identification of preliminary acceptance criteria (based on developing $K$ Basins SNF acceptance criteria) for the CSB and the identification and specification of the requisite conditioning, containment, and handling requirements for the 72 PWR-2 fuel assemblies to satisfy CSB acceptance.

As an option to removing and storing the PWR-2 fuel as specified above, the following were also considered and included as Appendices A, B, and C.

- (Appendix A - Continued Storage of the PWR-2 Fuel Assemblies in the $T$ Plant Pool) Determination of the consequences of continued storage of the PWR-2 fuel assemblies within the T Plant storage pool. This includes an evaluation of potential fuel assembly and storage facility deterioration over the next 40 years. 
- (Appendix B - Alternative Cask Storage Evaluation) Identification of alternative storage areas for the PWR-2 fuel assemblies within the Hanford Site and the evaluation of storage of the fuel assemblies within aboveground storage casks.

- (Appendix C - Safety Basis for Interim Cask Storage) Evaluation of the safety basis requirements for aboveground cask storage identified in Appendix B.

This work plan has been approved by both Solid Waste Disposal Division (SWDD), the present custodian of the fuel, and Spent Nuclear Fuel Projects (SNFPs), the proposed future custodian of the fuel and manager of the CSB.

\subsection{BACKGROUND}

\subsubsection{Requirement For Work Plan}

A DOE Memorandum of Understanding (MOU) between the Spent Nuclear Fuels Project Division (SFD) Office of the Assistant Manager for Waste Management and the Waste Programs Division (WPD) Office of the Assistant Manager For Waste Management was issued on June 17, 1996. The MOU defined the roles and responsibilities of the two groups for the Management of Spent Nuclear Fuel Currently Located at T Plant and the 200 Area Low-Level Burial Grounds. The MOU was issued to the president of Westinghouse Hanford Company (WHC) as correspondence number 96-SFD-166, and dated July 31,1996. The MOU states that the PWR-2 fuel currently stored in T Plant will be first placed into canisters and then moved to safe, compliant storage at the CSB.

The roles and responsibilities of the two groups regarding T Plant PWR-2 fuel were defined as follows:

Waste Programs Division:

- Maintain ownership of the PWR-2 fuel assemblies until acceptance by SFD at transfer from T Plant.

- Compile data records necessary for final disposition of the PWR-2 fuel in accordance with the Office of Civilian Radioactive Waste Management Quality Assurance requirements and Description, ref RW-0333P.

- During ownership by WPD obtain SFD concurrence prior to any action that could impact transfer of the PWR-2 to the CSB, or final disposition of the PWR-2 fuel.

- Perform activities within T Plant to load PWR-2 into canisters provided by SFD, dry the PWR-2 fuel, ensure closure of the canisters, and load canisters into casks. Provide input to SFD and interface requirements for T Plant canisters. 
- Establish and approve all T Plant internal procedures, documents, air permitting, and other environmental, safety, health, and Quality Assurance (QA) documentation required at T Plant.

- Establish and approve the safety authorization basis for all PWR-2 removal activities at T Plant.

Spent Nuclear Fuels Project Division

- Maintain cognizance of PWR-2 handling, packaging, cask loading, and transportation activities performed by WPD at T Plant.

- Approve, accept, and maintain PWR-2 data records.

- Provide canisters and casks for transport and interim storage of the PWR-2 fuel. Provide systems required for drying and closure of the canisters after loading. Provide technical requirements and engineering information to WPD necessary for WPD to develop internal procedures for canister loading, fuel drying, ensuring closure of the canisters, and cask loading.

- Establish and approve all procedures and documents required for transporting, receiving, and storing T Plant PWR-2 fuel at the CSB. Included is the safety analysis report for packaging for the PWR-2 fuel.

- Establish and approve the safety authorization basis for all SNF activities at the CSB.

- Establish and complete readiness review and accept stewardship of the PWR-2 fuel at shipment from T Plant, transfer loaded cask from T Plant to the CSB, and implement interim storage.

To facilitate these actions and responsibilities, WHC SWDD (for DOE WPD) has in canjunction with WHC SNFP (for DOE SFD), produced this work plan for removal of the PWR-2 fuel from T Plant and transfer of the Fuel to the CSB for storage.

\subsubsection{Fuel Assembly History}

The 72 PWR-2 fuel assemblies presently stored in T Plant were originally used in Core 2 of an experimental pressurized water reactor at the Shippingport Atomic Power Station at Shippingport, Pennsylvania. This reactor was operated by the U.S. Energy Research and Development Administration (now the U.S. Department of Energy [DOE]).

The principal objective of Core 2 research was the development of a seed and blanket core with a high performance in terms of both power density and lifetime. A high power density, high total energy core required the development of a fuel element of high loading that could withstand long irradiation exposure at high heat fluxes. Zircaloy-4 was chosen for the skeleton of the compartmented fuel plates and for the assembly cladding because of its low neutron and hydrogen absorption rates. The Core 2 reactor contained 97 assemblies, including the 72 standard blanket assemblies (natural uranium above 
96 percent theoretical bulk density), 20 seed assemblies, 4 special blanket assemblies, and 1 multipurpose extended life blanket assembly, which contained irradiated fuel from the first core.

The reactor operated from April 1965 through March 1969 with one set of seed assemblies and from July 1969 through February 1974 with a second set of seed assemblies. The 72 standard blanket assemblies, 4 special blanket assemblies, and 1 multipurpose assembly remained within the core during this entire operating period. The fuel assemblies average exposure during the PWR-2 irradiation was 16,200 megawatt day per metric tons uranium (MWD/MTU). The 72 standard blanket assemblies were shipped to the Hanford Site during 1978 and 1979 and have since been stored underwater in the 221-T Canyon. 


\subsection{SUMMARY}

This document is an initial work plan for the transfer of the 72 Shippingport PWR-2 blanket fuel assemblies from their current location in a T Plant storage pool to the CSB. The primary purpose of this plan is to:

- Provide information on the fuel assemblies.

- Identify existing and provide new functional requirements for interfacing equipment required to complete the transfer.

- Summarize the required safety and environmental documentation.

- Provide time and cost schedules for fuel removal activities.

- Identify potential obstacles that require resolution before transfer operations can commence.

The PWR-2 fuel assemblies were irradiated in an experimental nuclear reactor in Shippingport, Pennsylvania from 1965 to 1974 . The blanket fuel assemblies could not on their own sustain a criticality, but when located within the reactor with highly enriched 190 percent uranium-235) seed fuel assemblies, a criticality was maintained (Miller 1978). The blanket assemblies were transferred to T Plant canyon in 1978 and 1979 for reprocessing to recover produced plutonium. This never occurred and the fuel assemblies have remained within the water storage pool to the present time.

Prior to the anticipated time frame for PWR-2 fuel assembly removal from T Plant and transfer to the CSB, SNF stored in the K Basin (100-K Area) storage pools is already expected to be retrieved and transferred to the CSB. The CSB is currently under construction in Hanford's 200-East Area. The CSB complex is designed to receive and provide interim storage for SNF until a national SNF repository is completed and can provide a permanent disposal option. The CSB is designed to provide dry storage for SNF within underground storage tubes for up to 40 years and will satisfy the security requirements for Safeguards Category II SNF.

The PWR-2 blanket fuel assemblies are approximately $3.6 \mathrm{~m} 112 \mathrm{ft}$ ) long and $19 \mathrm{~cm}$ (7.5 in.) square and are divided into three primary sections: a middle fuel cluster and stainless steel top and bottom extension brackets. The fuel assembly dimensions häve been confirmed by actual physical measurement of a spare, unirradiated PWR-2 blanket fuel assembly and by comparison with construction drawings obtained from Westinghouse Bettis, the original PWR-2 fuel assembly designer. The fuel cluster is constructed of zircaloy-4 and was originally loaded with natural uranium in the form of uranium dioxide. After nine years of irradiation, the fuel assemblies contain fission and decay products, and quantities of actinides, such as plutonium, americium, and curium. The dose rate from a single fuel assembly is calculated to range from $3200 \mathrm{R} / \mathrm{hr}$ at the assembly surface to a maximum of $200 \mathrm{R} / \mathrm{hr}$ at one meter. These rates appear consistent with past WHC dose calculations. However, the calculations are an approximation and do not specifically account for the dose attributed to activation products (such as cobalt-60) in the stainless 
steel extension brackets. A detailed analysis of the dose rates from the extension brackets and the shielding effects of the canister, cask and shield plug are required using a more sophisticated modeling technique such as Monte Carlo.

Structural assessment of the PWR-2 fuel assemblies included a review of potential corrosion, fuel assembly bowing, potential failure of the fuel cladding, and the buildup of "crud" on the interior and exterior of the fuel assemblies. The assessment concluded that none of these items will affect the transfer of the fuel assemblies from the storage pool to the CSB. However, all of the information used for this assessment came from indirect sources; no physical examination or destructive testing of the actual PWR-2 fuel assemblies has been performed. It is recommended that four of the fuel assemblies are examined to confirm the pian assumptions before transfer operations commence. This examination is particularly relevant for the measurement of fuel assembly bow and crud buildup on the exterior of the fuel assemblies.

In order to simplify the process and minimize the cost of the PWR-2 fuel assembly transfer, the same transfer equipment used for K Basin SNF should be used for the PWR-2 fuel assemblies. This equipment includes the shielding/transport cask and cask transporter. The design of the T Plant Canister, except for minor internal changes, is identical to the multiple canister overpack (MCO) to be used for K Basin SNF retrieval. The minor internal changes consist of removal of the draw tube and bottom spacer and the addition of a vertical storage basket. Four PWR-2 assemblies will fit within each canister with sufficient clearance for an adequate operational margin. To facilitate the transfer of the fuel assemblies from the storage pool to the canister, it is recommended that a new transfer hoist be suspended from the existing canyon bridge crane. This will improve reliability (the bridge crane is nearly 50 years old) and will add a backup hoist during SNF movements. In addition, primary and secondary fuel assembly grapplers will need to be designed and built to transfer the fuel assemblies. A SNF vacuum drying/inerting skid will be placed in T Plant to dry and inert the fuel assemblies prior to shipment.

To load the PWR-2 fuel assemblies into canisters, it was concluded that the simplest method was to reverse the procedure used in 1978 and 1979 to transfer the fuel assemblies into the storage pool. This will include moving the container/cask/transporter within the $T$ Plant railroad tunnel and parking the transporter under the canyon/tunnel access cell. The access cell is adjacent to the PWR-2 storage pool cell. Using the canyon bridge crane, new transfer hoist, and new fuel assembly grapplers, the fuel assemblies can be individually raised out of the storage pool, allowed to drain, transferred over the partition between the two cells, and lowered into a canister. The T Plant Canister shield plug is placed on the canister, the canister is then sealed and the contained fuel assemblies dried using standard SNF vacuum drying equipment. The canister cavity is backfilled and inerted with an inert gas such as helium. The canister is then leak-tested to assure adequate sealing of the canister. Finally, the cask lid is fitted and the cask/transporter is driven out of the access tunnel to the CSB. All of these steps can occur manually except for the remote transfer of the fuel assemblies to the canister and the fitting of the canister shield plug. If safety assessment indicates that a reduction in the potential fall height of a fuel assembly is necessary, an alternative canister loading process, such as elevating the canister/cask within the access tunnel or submerging the T Plant canister within the storage pool for loading, can be used. 
The access ramp to the T Plant tunnel and the unimproved road that connects the ramp to the $T$ Plant access gate will need to be improved to support the size and weight of the canister/cask/transporter combination. The transport unit likely will be driven to the CSB using Route 3, the main east-west road between the 200 East and West Areas. A detailed assessment of this route in regards to underlying and overhung utilities needs to be completed. Upon arrival at the CSB, the T Plant Canister will be off-loaded and transferred to a storage tube in the same manner as a K Basin MCO. The T Plant Canisters will need to meet CSB acceptance criteria yet to be developed. The PWR-2 fuel assembly radionuclide inventory, thermal generation, and radiation dose rates in most cases are similar or less hazardous when compared to the K Basin SNF. Two exceptions are the presence of activation products (primarily cobalt-60) within the stainless steel extension brackets and of measurable quantities of curium-244 within the fuel cluster. Neither isotope are present to any great degree within $\mathrm{K}$ Basin fuel. The cobalt-60 is a concern because of the high energy gamma radiation it emits. Curium-244 is of limited concern but can undergo spontaneous fission (half life of $1.4 \times 10^{7}$ years) with the resulting emission of neutrons.

The current safety authorization basis documentation (safety basis) for T Plant, SNF transport, and the CSB are not adequate for the transfer of the PWR-2 fuel assemblies. Hence, an Unreviewed Safety Questions (USO) process will need to be initiated to upgrade the safety basis to allow for the transfer of the PWR-2 fuel assemblies. T Plant's Interim Safety Basis (ISB) document will need to be amended to allow for the transfer of the fuel assemblies from the storage pool to the railroad access tunnel. Currently, the ISB only covers the underwater storage of the assemblies within the storage pool. Due to the similarity of the PWR-2 and K Basin transportation phases, it is recommended that the MCO Safety Analysis Report for Packaging (SARP), currently in production, is modified to include the transfer of the PWR-2 fuel assemblies. Similarly, because of the perceived similar handling activities at the CSB for both the PWR-2 fuel assemblies and the $K$ Basin SNF, it is recommended that the CSB Safety Analysis Report (SAR), also in production, be modified to include PWR-2 fuel assemblies. These modifications to both the SARP and SAR will not be made until after both have been completed and approved for K Basin SNF retrieval and transfer to the CSB.

The PWR-2 fuel assemblies are addressed in the programmatic environmental impact statement (EIS) (DOE 1995c) for SNF at DOE sites. An Environmental Assessment (EA) is being prepared to address the management of "other" SNF, including Shippingport PWR-2 fuel assembly transfer. The Notice of Construction (NOC) for the CSB will need to be revised prior to storage of the PWR-2 fuel assemblies to address the increased radionuclide inventory present at the CSB due to the PWR-2 fuel assemblies. The fuel assemblies are not defined as waste and therefore, are not subject to Resource Conservation and Recovery Act (RCRA) regulations.

The T Plant canyon building will need to be evaluated for declared safeguards requirements when the PWR-2 fuel assemblies become non-self protecting in the future (approximately 2004). At this time the radiation dose from the PWR-2 fuel assemblies will have decreased below "self-protecting" levels according to DOE regulations for radioactive material. Material that is not classified as self-protecting (DOE 1994), is required to be stored in a more secured manner than self-protecting material. Currently, T Plant does not meet the increased safeguard requirements for other than Category IV-E material, however, the CSB is designed to store Category II quantities of K Basin's SNF. The CSB should be 
adequate for the PWR-2 fuel inventory. The safeguards department has stated that if the fuel assemblies are moved before they cease to be self-protecting, they will not require any armed guards or extraordinary security measures during transfer from T Plant to the CSB. To satisfy accountability requirements, the identification number of each PWR-2 fuel assembly will be noted during removal operations and will be recorded as contained in the respective serial numbered $T$ Plant Canister.

Following removal of the PWR-2 fuel assemblies from the T Plant storage pool, the pool will be decommissioned. This will include removal of the $190,000 \mathrm{~L}(50,000 \mathrm{gal})$ of pool water and the ion exchange column used for water purification. Since the pool water is only slightly contaminated with radionuclides and contains no hazardous materials, it will be transported to the Effluent Treatment Facility for treatment and eventual disposal. Similarly, the PWR-2 ion exchange column is considered low-level solid waste and will be disposed of in the Hanford low-level solid waste burial grounds.

The schedule (see Section 13) assumes that transfer of PWR-2 fuel from T Plant to the CSB cannot commence until after $K$ Basin transfers are complete. This schedule shows completion of PWR-2 transfers by March, 2001. The T Plant related cost of PWR-2 fuel assembly recovery, detailed in Section 14, is estimated to be $\$ 2,638,033$ in FY-1996 dollars. This does not include the cost of activities directed by SNFP supporting PWR-2 fuel removal.

Two alternative options to removing and storing the PWR-2 fuel in the CSB have been considered and are attached as Appendices $A$ and $B$. Both options assume that interim storage for approximately 40 years is required prior to final disposal in a deep geologic repository.

The first option (Appendix A) considered continued storage of the PWR-2 fuel in the existing T Plant pool. A durability assessment was conducted to determine the viability of continued storage of the PWR-2 fuel assemblies underwater in the T Plant storage pool and building. The assessment, based on a number of referenced studies, concluded that the fuel assemblies would not deteriorate significantly during the next 40 years if left in the $T$ Plant pool. This assessment is contingent on the $T$ Plant storage pool water quality remaining in its present condition. Of greater concern when considering an additional 40 years storage in the $T$ Plant pool was the potential for deterioration of the $T$ Plant canyon building, storage pool, and canyon services. Maintenance on the 50 year old canyon building to sustain an additional 40 years of operational life will likely require major expenditure on the canyon bridge crane, ventilation equipment, power supplies, communication equipment, etc. In addition, maintaining the 20 year old PWR-2 storage pool as a leak tight structure is likely to incur significant maintenance costs. The PWR-2 fuel assemblies will cease to be self protecting sometime after the year 2004 , and subsequent Hanford Site safeguard requirements would also require upgrades to T Plant's security arrangements. It is fikely that alternative storage in the CSB or cask storage, would be a more economical storage option.

The second option (Appendix B) considered the storage of PWR-2 fuel in commercial storage casks placed on concrete pads. The assessment also included an evaluation of suitable storage locations within the Hanford Site. A safety basis assessment of the storage of PWR-2 fuel assemblies in casks is attached as appendix C. 
Two aboveground cask storage systems were selected as typical systems and were evaluated in detail. These were Sierra Nuclear's Ventilated Storage Cask (VSC) and Vectra's Nuhoms' system. Both were determined to be suitable for the storage of PWR-2 fuel assemblies. A similar fuel assembly retrieval process to that outlined for $T$ Plant shipments to the CSB, can be used for transferring the fuel assemblies from the T Plant storage pool to either of the storage cask systems.

Sierra Nuclear's VSC system uses a concrete cylindrical storage cask design with an internal, removable, steel storage basket, which can hold up to 24 PWR-2 fuel assemblies in a vertical position. For use with PWR-2 fuel assemblies, the VSC storage cask would also be used as the transport cask from T Plant to the storage pad. The VSC storage cask, (weight 100 tons), would be transported via railroad car into and out of the T Plant tunnel. However, for final shipment to the storage area, the cask would need to be transloaded from the rail car to road transporter. The total cost of retrieval, transfer, and storage of the PWR-2 fuel assemblies using the VSC storage system is estimated to be $\$ 5.1$ million.

Vectra's Nuhoms system uses a portable semi-shielded steel SNF container that is transported to a fixed reinforced concrete storage module via a transport cask. The fixed storage module provides shielding during interim storage, while the transport cask provides shielding during transferal from the initial storage location to the Nuhoms" site. The Nuhoms" SNF container is equipped with an internal basket, which can also hold up to 24 PWR-2 fuel assemblies. The transport cask is moved using a custom built road and/or rail transporter. The transport cask is placed vertically for SNF loading and horizontally for transport and loading into the storage module. A Hydraulic ram is used to transfer the SNF container between the transport cask and storage module. The total cost of retrieval, transfer, and storage of the PWR-2 fuel assemblies using the Nuhoms ${ }^{\circ}$ storage system is estimated to be $\$ 5.4$ million.

An evaluation of alternative storage locations within the Hanford Site for the PWR-2 fuel assemblies (other than within the CSB) concluded that storage within the existing Plutonium Finishing Plant (PFP) protected area was likely to be the most economic alternative. This is because existing PFP security arrangements will satisfy the security requirements for the storage of non self protecting category II SNF. Storage within the proposed 200 Area Interim Storage Area was evaluated, but due to the limited security arrangements proposed for this site, and the expected safeguard requirements for the PWR-2 fuel assemblies after the year 2004 , the site was not considered an economic alternative.

For cask storage T Plant's ISB document will require an amendment to accommodate the transfer of fuel assemblies from the storage pool to the cask. It is assumed that the transport cask will have an approved Topical Safety Analysis Report (TSAR) and NRC Certificate of Compliance. A SARP would be required similar to that being prepared for the $K$ Basin MCO cask. If the PWR-2 fuel assemblies are transferred to the 200 Area Interim Storage Area (ISA), the CSB SAR would also need to be amended. If the fuel assemblies are to be stored at the PFP an update to the current PFP SAR will be required. 
This page intentionally left blank. 


\subsection{RECOMMENDATIONS}

\subsection{RECOVERY PROCESS}

The recommended recovery process to load the PWR-2 fuel assemblies into T Plant Canisters is the reverse of the procedure used in 1978 and 1979 to transfer the fuel assemblies into the storage pool (see Section 7.1). The process includes the dry transfer of fuel assemblies from the pool into a T Plant Canister contained within a transport cask in the $T$ Plant railroad tunnel; inserting the canister shield plug and vacuum drying the fuel assemblies; filling the canister with inert gas; sealing the T Plant Canister and cask; and transferring the fuel assemblies to the CSB for interim storage. This process is the simplest and most cost effective engineering option evaluated.

\subsection{FUEL ASSEMBLY CONDITION, CRUD BUILD-UP, BOW, AND OVERALL LENGTH.}

Confirmation of the condition and overall length of the PWR-2 fuel assemblies is important to the retrieval process. Consequently, it is recommended that prior to movement a minimum of four fuel assemblies are subjected to the following:

- Underwater video inspection of the fuel assemblies while using a scraper to disturb any crud on the assembly surface. This will indicate an approximate thickness, distribution, and quantity of any crud buildup. A sample of the crud would be collected and analyzed for content.

- Confirm the overall length of the fuel assembly within the T Plant pool using closed-circuit television (CCTV), a tape measure, and guide rod.

- Insertion of the fuel assemblies into a sizing gauge to determine if the fuel assembly bow is acceptable (i.e., less than $1.9 \mathrm{~cm}[0.75 \mathrm{in}$.$] ).$

- Underwater video inspection of the fuel assemblies to determine if there is any visible fuel assembly damage.

\subsection{FUEL ASSEMBLY RADIOACTIVE DOSE ANALYSIS}

Preliminary WHC calculations using different assumption for the distribution of cobalt -60 in the PWR-2 assemblies indicate that the dose rate calculations reported in Section 6.4.1 and 6.4.2 of this plan may be low (see Section 6.4.2.5). Also the source term reported in Section 6.0 of this plan is for an average fuel assembly and not the high burn fuel assemblies. The following is therefore recommended:

- Recalculate (by background review and new calculation) the source term used (see Table 6-2) for dose calculations and confirm this is a bounding source term. Initiate new detailed dose rate calculations using Monte Carlo or other similar computer code. These calculations are to use the most recent $K$ Basin $M C O$ and transport cask designs and would analyze the radiation dose rate from: 
- one bare assembly

- four assemblies in a T Plant Canister with fitted shield plug

- the canister/cask combination with and without the cask lid

These calculations are to identify the dose rate from the fuel cluster and fuel assembly extensions separately. The dose rate through the shield plug with four PWR-2 fuel assemblies loaded into the T Plant canister should also be measured.

- Undertake, using a newly calibrated instrument, actual dose rate measurements of the PWR-2 fuel assemblies within the T Plant storage pool. Detailed dose measurements would be collected both around the fuel assembly top extensions and fuel clusters. Both surface measurements and measurements at a distance would be collected. The shielding effects of the pool water will be calculated and subtracted so as to indicate equivalent dose measurements at distance in air. These measurements will confirm, or otherwise, the calculated radioactive dose rate values and source term.

- If the new dose calculations and storage pool dose measurements indicate that the radioactive dose rates reported in Section 6.4.1 and 6.4.2 are significantly low, a reevaluation of the recovery process, discussed in Section 7.0 , will be required.

It is considered likely that any increase in the calculated canister/cask dose rates will require the placement of temporary shielding around the canister/cask to protect workers during manual operations at the top of the cask.

\section{$3.4 \quad$ TRANSPORTATION}

For completeness it is noted here that the cask and transporter developed for $K$ Basins SNF will be used to transfer the PWR-2 assemblies to the CSB. The use of this equipment was specified as a plan requirement.

Both Facilities and Site Services (ICF Kaiser) and Safeguards recommended moving the PWR-2 fuel assemblies during the Spring/Summer/Autumn timeframe to:

- Reduce road damage induced by overweight vehicles traveling on icy and wet roads.

- Eliminate potential accidents caused by icy road conditions.

The current SNFP program (repeated in the schedule for this plan, Section 13) shows transfers from T Plant to the CSB starting on October 2, 2000 and continuing through the winter. This is not in agreement with Facilities and Site Services and Safeguards department recommendations above. It is therefore recommended that SNFP review the start date for PWR-2 fuel movements to the CSB. 
The WHC Security department recommended transporting the PWR-2 fuel assemblies during the normal working day (Monday to Friday between 8:00 am and 3:00 pm).

\subsection{TRANSPORT ROUTE}

A detailed review of the transport route between T Plant and the CSB should be undertaken to identify:

- Required upgrades to the T Plant rail tunnel access road and confirmation that the associated costs are within the budget estimate provided in this plan.

- Required upgrades to the northwest access road adjacent to $T$ Plant, which is presently unpaved. The upgrade costs should be confirmed to ensure that the budget estimate for the upgrades in this plan are reasonable.

- Utility modifications or temporary measures required both over the road (powerlines, telephone cables) and under the road (water lines, culverts etc.). Modification costs will need to be developed to confirm the budget estimate included within this plan.

\subsection{SAFETY BASIS DOCUMENTATION}

\subsubsection{T Plant Interim Safety Basis}

A hazards assessment should be performed as early as reasonably possible to identify the potential events that could release radioactive materials and identify whether a facility hazard Category 3 is justified. If arguments result in the facility being classified as hazard Category 2, source term reduction through the use of facility features and/or operating procedures must be taken into account. Quantitative accident analysis will need to show that the dose to onsite and offsite personnel will be acceptable. Because of the transient nature of the PWR-2 retrieval and transfer operation, it is recommended that the safety basis amendment package remain separate, as an amendment, from the ISB and that no significant revision be made to the ISB. When the PWR-2 operation has been completed and required cleanup activities have been performed, the amendment can be removed from the authorization basis documentation. Changes can then be made to the ISB that will consist only of removing text concerning the PWR-2 fuel assemblies and updating any text concerning modifications to the facility. 


\subsubsection{Transportation and Packaging}

A modification of the MCO cask SARP will be required for transfer of the PWR-2 SNF. Because of the common aspects between the PWR-2 and the K Basin transportation phase, it is recommended that the safety analysis for the PWR-2 transport be prepared as an addendum to the MCO cask SARP. The SNFP will be responsible for the preparation of these SARP modifications.

\subsubsection{Canister Storage Building}

A modification of the CSB SAR will be required for receipt and storage of the PWR-2 SNF. Because of the common aspects between the PWR-2 and $K$ Basin activities in the CSB, it is recommended that the safety analysis for the PWR-2 operation in the CSB be prepared as an addendum to the original CSB (K Basin) SAR. The SNFP will be responsible for the preparation of these CSB SAR modifications.

\subsection{ENVIRONMENTAL COMPLIANCE}

Although these are not recommendations but statements of fact, it is noted here that:

- $\quad$ SNFP is pursuing an EA regarding Storage of the Hanford Spent Nuclear Fuel; Non K Basins which will include PWR-2 SNF handling activities at T Plant, transfer to the CSB, and storage at the CSB.

- The Washington State Department of Health (WSDH) will need to be notified of all potential air emissions to be released during the retrieval and conditioning of the PWR-2 fuel, such as radiological contamination and weiding fumes. 


\subsection{UNCERTAINTIES, ASSUMPTIONS, RISKS , AND PLANS OF ACTION}

This section identifies the current plan uncertainties, the assumptions regarding each uncertainty, the risks to the plan if the assumptions are incorrect, and plans of action to mitigate the risks.

\subsection{PWR-2 FUEL ASSEMBLIES}

The following subsections provide uncertainties, assumptions, plans of action, and risks associated with retrieval and transfer of the PWR-2 fuel assemblies from the T Plant storage pool.

\subsubsection{Overall Structural Integrity}

Uncertainty. Are the 30-year old PWR-2 fuel assemblies capable of being picked up by the top extension bracket lift points without failure?

Assumption. The fuel assembly sections and connecting bolts are assumed to be in good structural condition as the PWR-2 fuel assemblies were safely transferred into T Plant in $1978 / 79$ using the top extension bracket lifting points. No significant corrosion is believed to have occurred within the storage pool during the interim period. This assumption is based on a metallurgical review of PWR-2 fuel assembly construction, process history within the Shippingport reactor, and conditions within the T Plant storage pool. (See Section 6.6.4 and Appendix A).

Risk. If a fuel assembly structurally fails during transfer from the storage pool to the T Plant Canister, the assembly could fall and, upon impact, release radionuclides into the $T$ Plant canyon. The canyon is designed as a containment building with radiation shielding and as the canyon is not manned during transfers the major risks are associated with subsequent recovery operations to retrieve a failed assembly.

Plan of Action. The risk of a falling assembly has been reduced by the use of two independent grapplers when transferring the fuel assemblies, as described in Sections 7:1.6 and 8.1.4. The primary grappler uses the standard top extension lifting points and a secondary grappler (provided in case of failure of the primary grappler) hooks under a bulge on the top extension bracket.

Uncertainty could be reduced further by sending a fuel assembly, in a suitable cask, to the expended SNF examination laboratory in Idaho Falls. Destructive analysis would confirm structural condition of the fuel assembly, especially the top extension bracket and the connection bolts. This plan of action is not recommended since the risk of structural failure is thought to be remote. 


\subsubsection{Fuel Cladding}

Uncertainty. No physical examination has been performed on the PWR-2 blanket fuel assembly cladding to determine if it has failed, allowing SNF to have direct contact with the storage pool water.

Assumption. The PWR-2 fuel assembly cladding has not been breached. This assumption is based on Bettis documents that state, 1) cladding failure was not detected in the reactor and 2 ) increase in fission product concentrations within the reactor coolant water were not detected. Further, cesium-137 concentrations within the T Plant storage pool have remained consistently low (less than $1 \times 10^{-6} \mu \mathrm{Ci} / \mathrm{ml}$ ).

Risk. If any of the PWR-2 fuel assembly cladding has failed, storage pool water will have penetrated the cladding, causing fission products to leach into the storage pool and potentially causing the uranium dioxide fuel to react with the water causing further cladding failure. If cladding failure is determined, additional examination of the fuel will be necessary to determine what is required to prepare the fuel for safe interim storage.

Plan of Action. Continue pool water quality monitoring.

\subsubsection{Fuel Bow}

Uncertainty. Based on Bettis documents, it is likely that the PWR-2 fuel assemblies have bowed to some extent due to uneven heating within the Shippingport reactor. However, no information has been found to indicate the extent of PWR-2 fuel assembly bowing.

Assumption. The PWR-2 fuel assemblies are not bowed more than $1.9 \mathrm{~cm}(0.75 \mathrm{in}$.$) . This$ assumption is based on Bettis documents that indicate a maximum bow of only $0.20 \mathrm{~cm}$ (0.12 in.) for the Shippingport Light Water Breeder Reactor (LWBR) blanket fuel assemblies (Core 3).

Risk. If any of the PWR-2 fuel assemblies have bowed greater than the assumed canister/fuel assembly clearance $[1.9 \mathrm{~cm}(0.75 \mathrm{in})$.$] , they could become jammed when$ being inserted into the $T$ Plant Canister during transfer operations. In addition, excessively bowed fuel assemblies would require a modified $T$ Plant Canister that would transfer only three assemblies instead of the planned four to increase assembly clearance. In turn, this would increase the number of storage tubes required in the CSB.

Plan of Action. Measure the bow of a representative set of assemblies as stated in Section 3.2

\subsubsection{Criticality}

Uncertainty. Because a criticality assessment has not been performed for the transfer of the PWR-2 fuel assemblies from the storage pool to the T Plant canister, it is uncertain whether a valid criticality concern exists. This uncertainty assumes that a catastrophic failure of a fuel assembly during transfer from the storage pool to the T Plant Canister in the railroad tunnel can occur. 
Assumption. The PWR-2 blanket fuel assemblies cannot assume a critical condition. Therefore, there are no criticality configuration requirements for transfer and storage of four PWR-2 fuel assemblies within the T Plant Canister. This assumption is based on the $k_{\infty}$ for the most reactive fuel assemblies being only 0.91 , that any catastrophic accident would most likely occur in air (reducing the effective $k$ value), and that the scenario in which the fuel becomes separated from the cladding is not considered credible. A criticality assessment was performed to transfer the fuel assemblies into the storage pool from a transportation cask in 1978. This assessment concluded that no criticality concerns were present as long as the fuel was not separated from its cladding and no additional fissile material was added storage pool.

Risk. If the potential for a criticality accident can be shown to exist, then the basket configuration within the T Plant Canister will need to be modified to separate the fuel assemblies and a different, more complicated, transfer system would need to be developed to reduce the possibility of a catastrophic failure.

Plan of Action. Perform a criticality evaluation to determine if any arrangement and/or circumstance could result in a criticality situation. The evaluation would have to cover fuel handling, fuel transfers in the canister/cask, and fuel movements and storage within the CSB.

\subsubsection{Crud Deposits}

Uncertainty. Several documents refer to oxide deposits and crud layers on the interior fuel plates observed on disassembled fuel assemblies. It is suspected that crud deposits also exist on the exterior of the fuel assemblies. During fuel transfer and draining activities, these crud deposits could become airborne and/or contaminate the exterior of the canister/cask.

Assumption. Crud deposits on the PWR-2 fuel assemblies will not be a problem during transfer operations. This assumption is based on the fact that the fuel assemblies were safely transferred into the T Plant storage pool in 1978/79 and that no further crud deposits would have formed during the interim period. In addition, the fuel will be transferred wet, limiting airborne emissions, and the exterior of the canister/cask would be covered with protective coverings to limit fallen contamination spread.

Risk. Spread of contamination will occur within the canyon if crud deposits become airborne. If the canister/cask became contaminated, CSB acceptance requirements would require decontamination prior to acceptance. However, since T Plant's current mission is as a beta-gamma decontamination facility, decontamination of the canister/cask should not be a problem.

Plan of Action. Sample and analyze sludge deposits on the external surface of the fuel assemblies as stated in Section 6.7.4. Determine crud characteristics and estimate quantity of sludge present on the assemblies. 


\subsubsection{Radiation Dose Rates}

Uncertainty. Recent WHC preliminary dose calculations (not yet confirmed or checked) for the PWR-2 fuel assemblies have indicate dose rates higher than the assessments used as a basis for this plan (Section 6.4). These new calculations have assumed that the cobalt-60 isotope is concentrated in the top and bottom extension brackets and not spread throughout the assembly as previously assumed.

Assumption. The scheduled delivery date of this removal plan does not allow for the completion and incorporation of the new dose rate calculations into the plan. Therefore, the plan has been issued based on the existing dose rate calculations found in Section 6.4.

Risk. If these new assumptions and calculations, when completed and checked, indicate that radiation dose rates are likely to be higher than previously anticipated, a reevaluation of the removal process, discussed in Section 7.0, will be required. It is considered likely that any increase in canister/cask dose rates will require the placement of temporary shielding around the canister/cask to protect workers during manual operations around the top of the cask (e.g., vacuum drying and lid sealing operations). If the dose rates are determined to be considerably higher than previously calculated, then manual processing may not be possible and remote facilities may be needed.

Plan of Action. Confirm by background checks and new calculations the source term assumed for the reported dose calculations and initiate new detailed dose rate calculations using the Monte Carlo computer code. These calculations are to identify the dose rate from the fuel cluster and fuel assembly extensions separately. Measure the actual dose rates of the PWR-2 fuel assemblies within the T Plant storage pool. These measurements will confirm, or otherwise, the calculated radioactive dose rate values and source term.

\subsection{T PLANT CANISTER}

The following subsections provide uncertainties, assumptions, plans of action, and risks associated with the T Plant canister.

\subsubsection{Canister Internal Dimensions}

Uncertainty. Since the final design for the K Basin MCO has not been determined, the potential exists that the PWR-2 fuel assemblies would not fit within the K Basin MCO. Currently, both the horizontal and vertical MCO internal dimensions allow sufficient clearance for insertion of four PWR-2 fuel assembiles.

Assumption. The internal dimensions of the $\mathrm{K}$ Basin MCO final design will accommodate four PWR-2 fuel assemblies. This assumption is based on conversations with K Basin MCO design coordinators, which indicate the internal dimensions of the final MCO design are not anticipated to change from the existing preliminary designs. 
Risk. If the $\mathrm{K}$ Basin MCO inner dimensions are reduced to a point that less then four PWR-2 fuel assemblies can be inserted, placement of all 72 PWR-2 fuel assemblies within the CSB could be in jeopardy. If the internal vertical clearance is reduced so that the PWR-2 fuel assemblies no longer fit, a unique T Plant Canister would need to be procured/developed.

Plan of Action. Verify the finalized MCO design dimensions against PWR-2 assembly dimensions when available. Final MCO design dimensions are programmed to be completed, third quarter of fiscal year 1997.

\subsection{TRANSPORTATION ROUTE}

The following subsections provide uncertainties, assumptions, plans of action, and risks associated with the transportation route used to transport the PWR-2 fuel assemblies from T Plant to the CSB.

\subsubsection{Transport Route}

Uncertainty. It has not been officially determined if the identified route can accommodate the loaded PWR-2 cask/transporter without major modifications. The scope of this plan does not provide a detailed evaluation of the transport route, which would include a review of road loadings and utility interfaces.

Assumption. The current route from T Plant to the CSB complex is acceptable and overweight and oversize permits will be obtained for PWR-2 transfers. It is also assumed that the plan budget allowance for the (road) utility modifications is sufficient. Brief route discussions with ICF Kaiser (Hanford facilities and site services) did not identify any major problems.

Risk. If the identified route cannot accommodate the PWR-2 cask/transporter, an alternate route would need to be determined or the initial route upgraded at a cost in excess of the plan budget cost estimate.

Plan of Action. Perform a detailed route evaluation to determine if any impediments or limitations exist which need to be corrected prior to the transfer of the cask.

\subsubsection{T Plant Access Road/Ramp}

Uncertainty. It is not known if the T Plant tunnel road access ramp is adequate to accommodate the cask/transporter. Also, the access road connecting the ramp to the $T$ Plant parking lot is currently unmarked and unimproved. It is unclear whether the PWR-2 SNF would be allowed to be transported over this area.

Assumption. The unimproved access road and the road access ramp to the T Plant rail tunnel can be modified to accommodate the loaded cask/transporter without cost impacts in excess of the budget estimate in this plan. 
Risk. Extensive upgrades may be required to the access road and/or ramp to the T Plant railroad tunnel in excess of the plan budget allowance.

Plan of Action. Perform an evaluation of the T Plant tunnel road access ramp to determine required upgrades and cost.

\subsection{CANISTER STORAGE BUILDING}

The following subsections provide uncertainties, assumptions, plans of action, and risks associated with the CSB.

\subsubsection{Acceptance Criteria}

Uncertainty. The CSB acceptance criteria required for PWR-2 fuel assemblies have not yet been determined. The following table (Table 4-1) lists the general attributes of PWR-2 fuel assemblies, conditioning, and containment that have been assumed acceptable to the CSB in this plan.

Table 4-1. Assumed CSB/PWR-2 Fuel Assembly General Acceptance Criteria.

\begin{tabular}{|l|l|}
\hline Activity & $34,000 \mathrm{Ci} / \mathrm{PWR}-2$ Fuel Assembly \\
\hline Fuel Conditioning & $\begin{array}{l}\text { Water removal via cold vacuum drying and } \\
\text { subsequent inerting of the canister }\end{array}$ \\
\hline $\begin{array}{l}\text { Dose Rates (4 PWR-2 Fuel Assemblies in a } \\
\text { T Plant Canister) }\end{array}$ & $900 \mathrm{rem} / \mathrm{hr}$ (Surface) \\
\hline Decay Heat & 400 watts/hr/T Plant Canister \\
\hline $\begin{array}{l}\text { Filled T Plant Canister Weight (canister plus } \\
\text { 4 PWR-2 Fuel Assemblies) }\end{array}$ & $3,600 \mathrm{~kg} \mathrm{(8,000} \mathrm{\textrm {lb } . )}$ \\
\hline Primary Containment Confirmation & $\begin{array}{l}\text { The T Plant Canister will be filled with an } \\
\text { inert gas and will be pressure tested to } \\
\text { confirm primary containment capability. } \\
\text { The type of inerting gas and the test } \\
\text { pressure to be acceptable to CSB. }\end{array}$ \\
\hline
\end{tabular}

Assumption. Four PWR-2 fuel assemblies in a T Plant Canister with the attributes listed in Table 4-1 will be acceptable to the CSB.

Risk. If the PWR-2 fuel assemblies can not meet the CSB acceptance criteria (even with additional conditioning\}, an aiternate storage location would need to be determined. Any alternate location would need to be a secured area since the PWR-2 fuel assemblies will cease being considered self-protecting within the next 10 years.

Plan of Action. Incorporate criteria into fuel removal plan activities as they become more definitive. 


\subsection{SAFETY ASSESSMENT}

The following subsections provide uncertainties, assumptions, plans of action, and risks associated with the required safety assessments for the retrieval of PWR-2 fuel assemblies.

\subsubsection{Safety Basis}

Uncertainty. It is not certain that a safety basis can be developed for the direct transfer of PWR-2 fuel assemblies from the T Plant storage pool into a T Plant Canister within the railroad tunnel access cell. This process is the reverse of that used to transfer the fuel assemblies to the storage pool from the Bettis M-160 cask in 1978 and 1979.

Assumption. A safety basis will be approved for the direct transfer of PWR-2 fuel assemblies. The bases for this assumption is that an acceptable safety basis was developed for the 1978 and 1979 transfer process into the storage pool.

Risk. If a safety basis cannot be made for the direct transfer of PWR-2 fuel assemblies, another fuel assembly transfer alternative would need to be developed. This could involve either transferring the T Plant Canister directly into the storage pool for loading or simply elevating the canister/cask within the railroad tunnel to limit the potential fall height. These two options are discussed in Section 7.2.

Plan of Action. Provide contingency planning until such time that it can be determined whether a safety basis can be developed for the preferred method of fuel transfer.

\subsubsection{Hazard Category}

Uncertainty. It is unclear whether the proposed PWR-2 fuel assembly transfer plan within T Plant will require the facility hazard category to be increased from a hazard Category 3 to a hazard Category 2.

Assumption. Arguments will be developed that will show T Plant can remain a hazard Category 3 facility during PWR-2 fuel assembly transfer operations.

Risk. If it is concluded that T Plant would need to be reclassified to a hazard Category 2 under the current PWR-2 transfer plan, source term reduction through the use of facility features and/or operating procedures must be taken into account. This will require the features used to be classified "safety significant" and shown to meet specified design and operating criteria. Quantitative accident analysis will need to show that dose to onsite personnel will be acceptable. The development of Interim Operational Safety Requirements (IOSRs) may be required.

Plan of Action. As early as possible determine the hazard category of the activity. Provide contingency planning until such a time that the hazard category of the activity can be determined for the preferred method of fuel transfer. 


\subsubsection{Transportation and Packaging}

Uncertainty. It is uncertain whether the T Plant Canister loading operations are more or less hazardous in terms of radioactive inventory, when compared to K Basin MCO loading. This is because of the presence of cobalt- 60 in the stainless steel extension brackets and of significant quantities of curium-244 in the fuel cluster. Neither isotope is present in large quantities within $\mathrm{K}$ Basin SNF.

Assumption. T Plant Canister loading operations will be similar to the maximum $K$ Basin MCO loading hazards (assumed to be a full load of Mark IV fuel assemblies) and will fall within the established safety envelopes. It is assumed that the presence of cobalt- 60 and curium-244 within the PWR-2 fuel assemblies will not effect the transportation and packaging activities.

Risk. If the T Plant Canister loading operations are more hazardous, analysis will be required to determine the additional safety measures required for canister loading operations and to determine the level of the CSB acceptance criteria compliance.

Plan of Action. Identify if additional measures and/or analysis will be required to safely load the PWR-2 assemblies. This includes an impact analysis of the cobalt-60 and curium-244 within the fuel assemblies. The system will also be analyzed to determine the potential hazards involved and, if necessary, design solutions to mitigate the hazards found.

\subsubsection{CSB Safety Analysis}

Uncertainty. It is uncertain whether the procedure for retrieval and transfer of the T Plant Canister from the transfer cask to a storage tube within the CSB for temporary storage is the same as for K Basin MCO retrieval and transfer for interim storage.

Assumption. The retrieval and transfer procedure for T Plant Canister temporary storage is assumed to be the same as for K Basin MCO interim storage.

Risk. If the procedure is not essentially the same, a unique hazards assessment will be required. Additional analysis of unique accidents might also be required.

Plan of Action. Identify if additional measures will be required to safely unload and store the T Plant Canisters. Analyze the system to determine the hazards involved and, if necessary, design solutions to mitigate the hazards.

\subsection{ENVIRONMENTAL COMPLIANCE}

The following subsections provide uncertainties, assumptions, plans of action, and risks associated with the environmental compliance requirements for retrieval and transfer of the PWR-2 fuel assemblies. 


\subsubsection{National Environmental Policy Act Review}

Uncertainty. Since the PWR-2 fuel assemblies have not been examined to verify their physical condition, uncertainty exists as to whether some of the fuel cladding has failed.

Assumption. This plan assumes that the EA will result in a finding of no significant impact and an EIS will not be required. This is likely since there is currently no indication of cladding failure and because of the impressive track record of zircaloy cladding in general.

Risk. If the PWR-2 fuel assemblies (especially the fuel cladding) are found to be deteriorated, the EA may find that there is a potential for significant impact and an EIS may be required. Preparation of an EIS would involve a significant increase in cost.

Plan of Action. Preparation of an EA is underway, no further action is required until the findings of the EA are presented.

\subsubsection{Permitting}

Uncertainty. It is uncertain what radioactive or hazardous air emissions will occur during PWR-2 fuel assembly retrieval and conditioning. Potential radioactive sources include crud on the fuel assembly exterior and release of radionuclides during cold vacuum drying. Hazardous and/or radioactive materials could also be released during shield plug welding activities if the welded shield plug canister design is used. However, the fuel assembly cladding is assumed to be in good condition and even if failure has occurred, no air emissions from the nuclear fuel itself would be anticipated during normal operations.

Assumption. It is possible that crud deposits on the surface of the fuel could create airborne radioactive contamination and hazardous materials could be released during any welding activities. If any welding is to be performed or if it is discovered that a potential exists for a hazardous material to become airborne, the Washington State Department of Ecology (Ecology) will be informed and approval to proceed granted. However, the overall assumptions are that the costs for modifying the CSB NOC and Air Permit are minimal and upgrades to the T Plant stack are unnecessary. The WSDH will also be informed of potential air emissions during PWR-2 fuel assembly retrieval and conditioning activities. Since any releases would be contained within the T Plant canyon or caught by the canyon ventilation filter system, approval to proceed with the operation is expected.

Risk. If the planned precautions (primarily canyon containment) for potential air emissions are found to be inadequate, additional costs may be incurred in negotiations with regulators, preparation of air permit documentation, and/or for upgrading the monitoring equipment at T Plant.

Plan of Action. Meet with WSDH for a determination of whether an NOC would be required or this activity could be covered at a routine monthly meeting held with WSDH. If the welded canister shield plug design is used, determine if any hazardous materials could potentially be generated. If hazardous materials are potentially generated, Ecology will need to be informed and a determination made as to whether current precautions are adequate. 
This page intentionally left blank. 


\subsection{FUNCTIONAL ANALYSIS OF PWR-2 FUEL TRANSFER}

The following functional analysis was performed on the task of transferring the PWR-2 fuel assemblies from T Plant to the CSB.

\subsection{GROUND RULES}

The following ground rules were imposed on preparation of this plan. These ground rules help define the limits of the functions presented.

- The PWR-2 fuel assemblies will be transferred to the CSB and stored in the same storage tubes as the $\mathrm{K}$ Basin fuel.

- There will be nine available storage tubes at the CSB reserved for PWR-2 fuel assemblies. (Two canisters per tube.)

- The same transport cask and transporter used for $\mathrm{K}$ Basin fuel retrieval will be used for PWR-2 fuel assemblies.

- The T Plant Canister will be of similar design to the K Basin MCO to ensure that the T Plant Canister will be completely compatible with the transport equipment and the CSB.

- PWR-2 fuel transfer from T Plant to the CSB will not compromise the schedule commitments for removal of SNF from $\mathrm{K}$ Basins.

- Post transfer decommissioning and decontamination (D\&D) of the PWR-2 storage pool is limited to disposal of the pool water and ion exchange column.

\subsection{FUNCTIONAL REVIEW AREAS}

Seven major functions were identified and broken down into sub-functions. This report examines each of these functions with their sub-functions and determines each of their respective performance requirements. The seven functions and their performance requirements are summarized in Figure 5-1 and Table 5-1. Cost and scheduling are not included as functions, but are presented in this report as part of the overall analysis of the functions. 

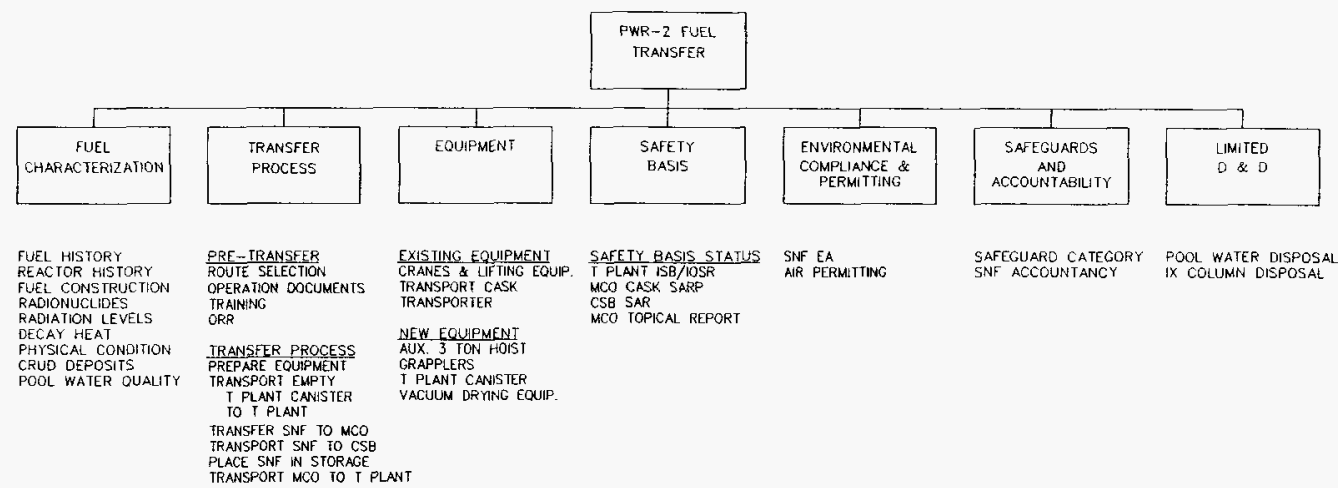

ROUTE SELECTION OPERATION DOCUMENTS TRAINIIC

IRANSFER PROCESS PREPARE EQUAPMENT TRANSPORT EMPTY IO PLANT CANISTEA TO F PAN CAN

TRANSFER SNF TO MCO

PLACE SNF IN STORAGE
TFANSPORT MCO TO T PLAN

EXISIIHC: EOUIPMENI TRANSPORTER

NEW EQUPMENT

GRAPPLERS

T PLANT CANISTER
VACUUM DRYINC EQUIP.

SAFEIY BASIS STATLS T FLANT ISB/IOSR CSE SAR

WCO IOPICAL REPORT

SNF EA
AIR FERMITTINO

SAFEGUARO CATEGORY SNF ACCOUNTANCY

POOL WATER DISPOSAL 
Table 5-1. PWR-2 Fuel Assembly Transfer

Functional Performance Requirements. (2 sheets)

\begin{tabular}{|c|c|}
\hline Finctionar Aros & Prominanoe requirenents \\
\hline Fuel Characterization & $\begin{array}{l}\text { Preliminary Requirements for the Disposition of DOE Spent Nuclear } \\
\text { Fuel in a Deep Geological Repository, Rev.O. }\end{array}$ \\
\hline Transfer Process & $\begin{array}{l}\text { Personnel selection, Qualification, Training, and Staffing } \\
\text { Requirements at DOE Reactor and Non-Reactor Facilities, DOE } \\
\text { Order } 5480.20 \mathrm{~A} \\
\text { Start-up and Restart of Nuclear Facilities, DOE Order } 5480.31 \\
\text { Planning and Conduct of Operational Readiness Reviews, } \\
\text { DOE-STD-3006-93 } \\
\text { Hanford Site Radiological Control Manual, DOE-RI HSRCM-1 } \\
\text { Hazardous Material Packaging and Shipping, WHC-CM-2-14 } \\
\text { Preliminary Requirements for the Disposition of DOE Spent Nuclear } \\
\text { Fuel in a Deep Geological Repository, Rev.O. }\end{array}$ \\
\hline Equi & $\begin{array}{l}\text { OSHA, } 29 \text { Code of Federal Regulations } \\
\text { Overhead Hoists, (underhungl, ANSI/ASME B30.16 } \\
\text { Below-the-Hook Lifting Devices, ANSI/ASME B30.20 } \\
\text { Performance Specification for the T Plant Canister - To be Prepared } \\
\text { by SNFP } \\
\text { Spent Nuclear Fuel Conditioning Criteria for the PWR-2 Fuel } \\
\text { Assemblies - To be prepared by SNFP } \\
\text { Specification for T Plant SNF Cask and Transportation System - To } \\
\text { be prepared by SNFP }\end{array}$ \\
\hline Safety Basis & $\begin{array}{l}\text { Unreviewed Safety Questions, DOE Order } 5480.21 \\
\text { Standard Operating Practices, WHC-CM-1-5 } \\
\text { Solid Waste Disposal Operations Administration, WHC-CM-5-34 } \\
\text { Hazard Category and Accident Analysis Techniques for } \\
\text { Compliance with DOE Order 5480.23, DOE-STD-1027-92 } \\
\text { Packaging and Transportation Safety, DOE Order } 460.1\end{array}$ \\
\hline
\end{tabular}


Table 5-1. PWR-2 Fuel Assembly Transfer

Functional Performance Requirements. (2 sheets)

\begin{tabular}{|c|c|}
\hline Functional Area & 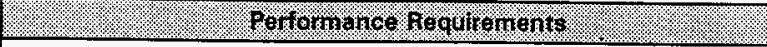 \\
\hline $\begin{array}{l}\text { Environmental } \\
\text { Compliance and } \\
\text { Permitting }\end{array}$ & $\begin{array}{l}\text { National Environmental Policy Act, } 40 \text { CFR } \\
40 \text { CFR } 61, \text { National /Emissions Standards for Hazardous Air } \\
\text { Pollutants } \\
\text { WAC 246-247, Radiation Protection Air Emissions }\end{array}$ \\
\hline $\begin{array}{l}\text { Safeguards and } \\
\text { Accountability }\end{array}$ & $\begin{array}{l}\text { Control and Accountability of Nuclear Materials, DOE 5633.3B } \\
\text { Material Control and Accountability Plan, WHC-IP-1019 } \\
\text { Safeguards Material Control Manual, WHC-CM-4-35 } \\
\text { Safeguards Accountability Manual for Chemical Processing } \\
\text { Division, WHC-CM-4-50 }\end{array}$ \\
\hline Limited D\&D & $\begin{array}{l}\text { Radiation Protection of the Public and Environment, DOE Order } \\
5400.5 \\
\text { Hanford Site Solid Waste Acceptance Criteria, WHC-EP-0063, } \\
\text { Rev. } 4\end{array}$ \\
\hline
\end{tabular}




\subsection{PWR-2 FUEL ASSEMBLY CHARACTERIZATION}

\subsection{PWR CORE 2 BLANKET FUEL ASSEMBLIES}

The Shippingport PWR-2 fuel assemblies are stored in the Cell $2 \mathrm{R}$ storage pool in the 221-T canyon facility at $T$ Plant. Cell $2 R$ is adjacent to the railroad tunnel access to T Plant (Cell 2L). PWR-2 fuel assemblies, in increments of 12 per shipment, were transported from Shippingport to T Plant in a Bettis M-160 Cask by rail under DOE escort in 1978 and 1979. Upon receipt, they were unloaded via remote and manual control and placed into underwater storage racks in Cell $2 \mathrm{R}$. The water acts as shielding for radioactivity and also keeps the fuel assemblies cool. The assemblies are stored in two racks at one end of the storage pool. Half of the storage cell is covered with $1.8 \mathrm{~m}(6 \mathrm{ft})$ thick concrete cover blocks. The cover blocks prevent damage to fuel assemblies potentially caused by falling objects. The remainder of the storage pool surface is open to the canyon.

\subsection{PWR-2 FUEL ASSEMBLY CONSTRUCTION}

Figures 6-1, 6-2, 6-3, and 6-4 show details and dimensions of the PWR-2 blanket fuel assemblies. In addition, the following table (Table 6-1) provides a summary of blanket fuel assembly information.

Table 6-1. PWR-2 Fuel Assembly Construction Details.

\begin{tabular}{|c|c|}
\hline Number of Assemblies & 72 \\
\hline Length & $361 \mathrm{~cm}(142.3 \mathrm{in.})$ \\
\hline Maximum Width & $19 \mathrm{~cm}(7.5 \mathrm{in}$.$) square$ \\
\hline Original Fuel Content & Natural Uranium Oxide $\left(\mathrm{UO}_{2}\right.$ ) (no enrichment) \\
\hline Construction Materials & $\begin{array}{l}\text { Zircaloy-4 (Fuel Cluster and Cladding); Stainless Steel-304 } \\
\text { (Top and Bottom Extension Brackets and Bolts) }\end{array}$ \\
\hline Total Weight & $536 \mathrm{~kg} \quad(1180 \mathrm{lb})$ per assembly \\
\hline Average Fuel Weight & $\begin{array}{l}225.5 \mathrm{~kg}(496.1 \mathrm{lb}) \text { Uranium and } \\
1.67 \mathrm{~kg}(3.67 \mathrm{lb}) \text { Plutonium per assembly }\end{array}$ \\
\hline
\end{tabular}

The PWR-2 fuel assemblies are comprised of three basic sections that are bolted together (an extended fuel cluster with top and bottom extension brackets). The fuel cluster consists of two identical oxide fuel plate sub-assemblies welded together to form a square structure and two zircaloy-4 cluster extensions welded to the ends of the sub-assemblies. 
Figure 6-1. PWR-2 Fuel Assembly.

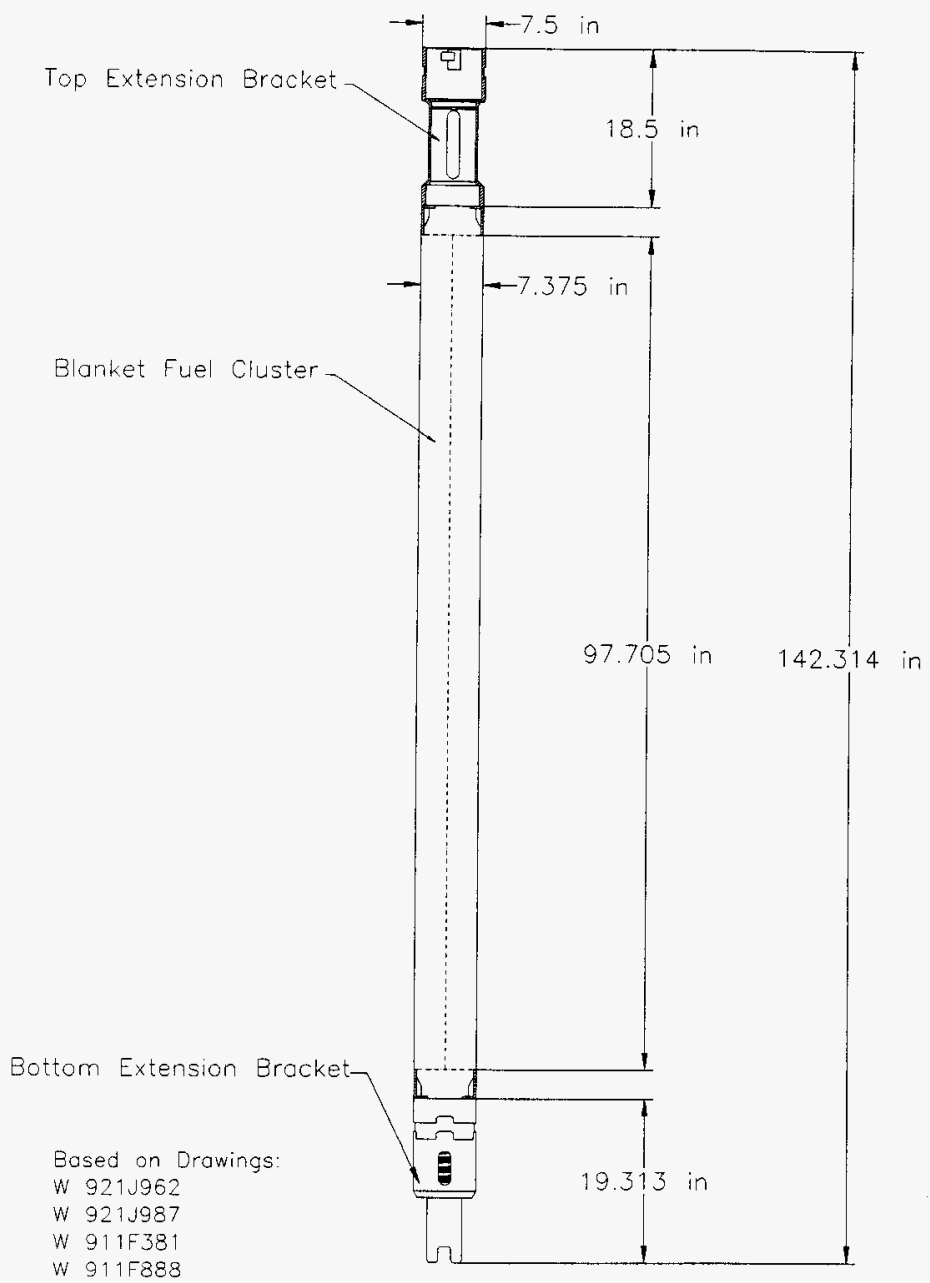


Figure 6-2. PWR-2 Fuel Assembly Top Extension Bracket (inches) (Atherton et al. 1968).
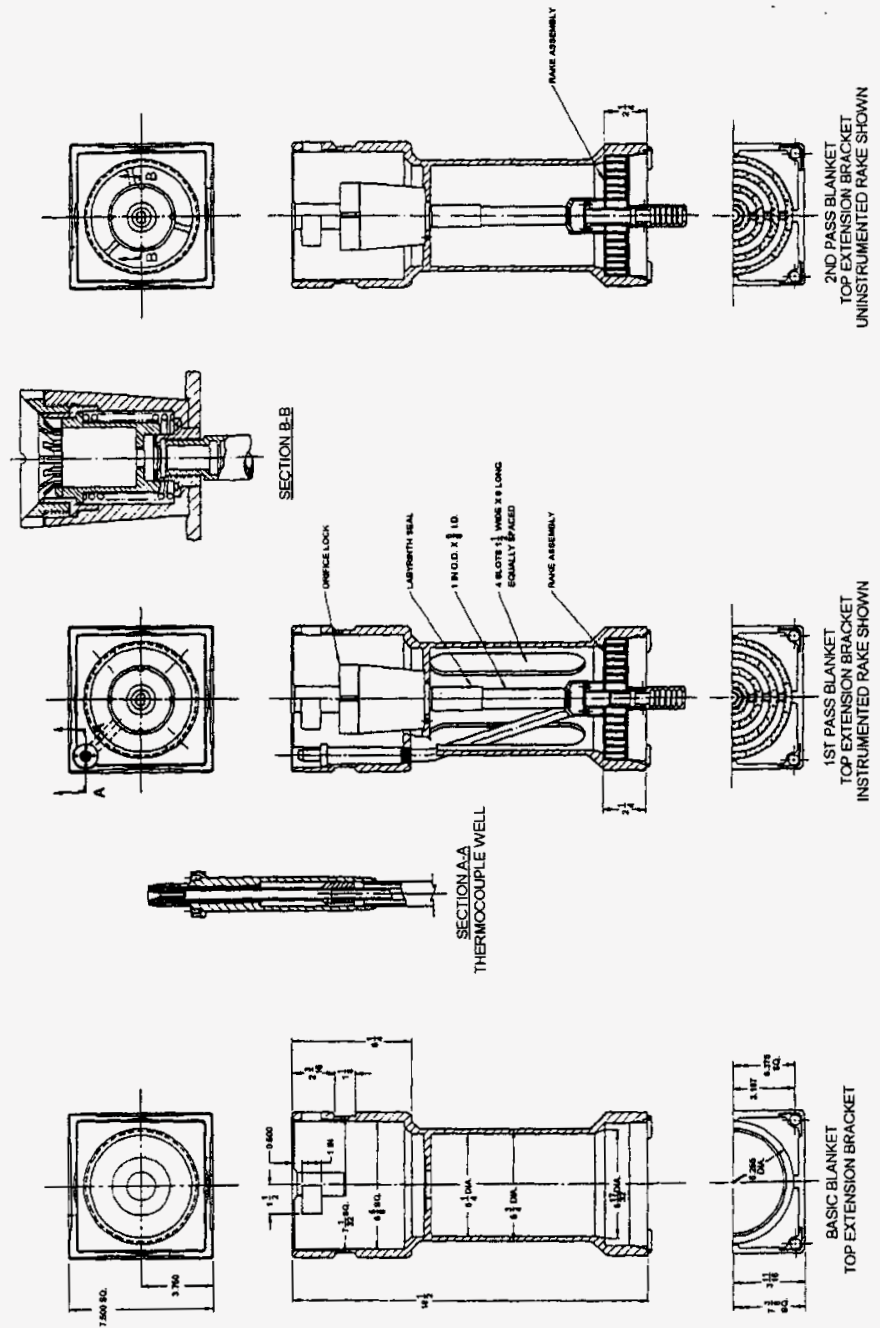
Figure 6-3. PWR-2 Fuel Assembly Fuel Cluster (inches) (Atherton et al. 1968).
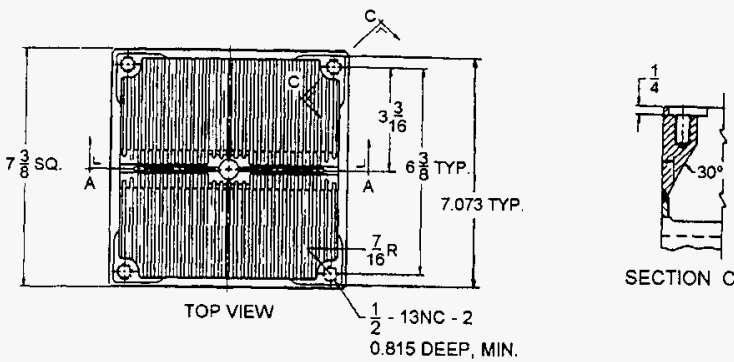

SECTION C - C

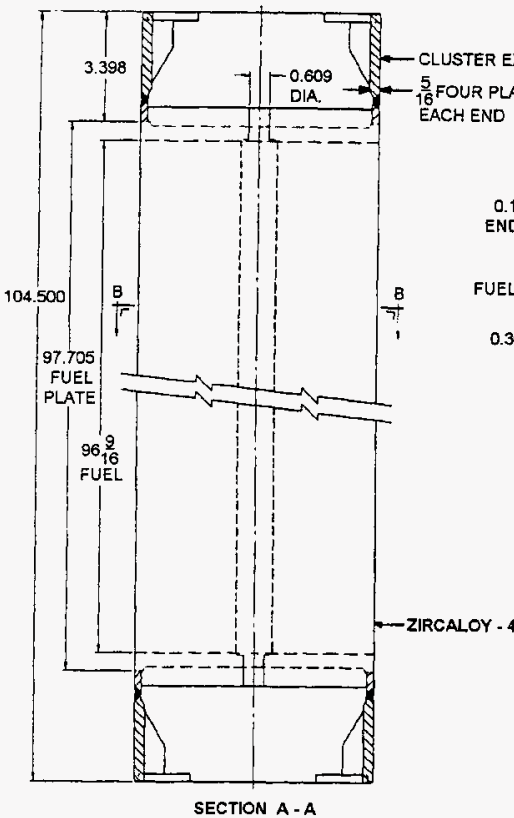

NOTE:

ALL DIMENSIONS ARE IN INCHES UNLESS OTHERWISE NOTED 
Figure 6-4. PWR-2 Blanket Assembly Bottom Extension Bracket (inches) (Atherton et al. 1968).

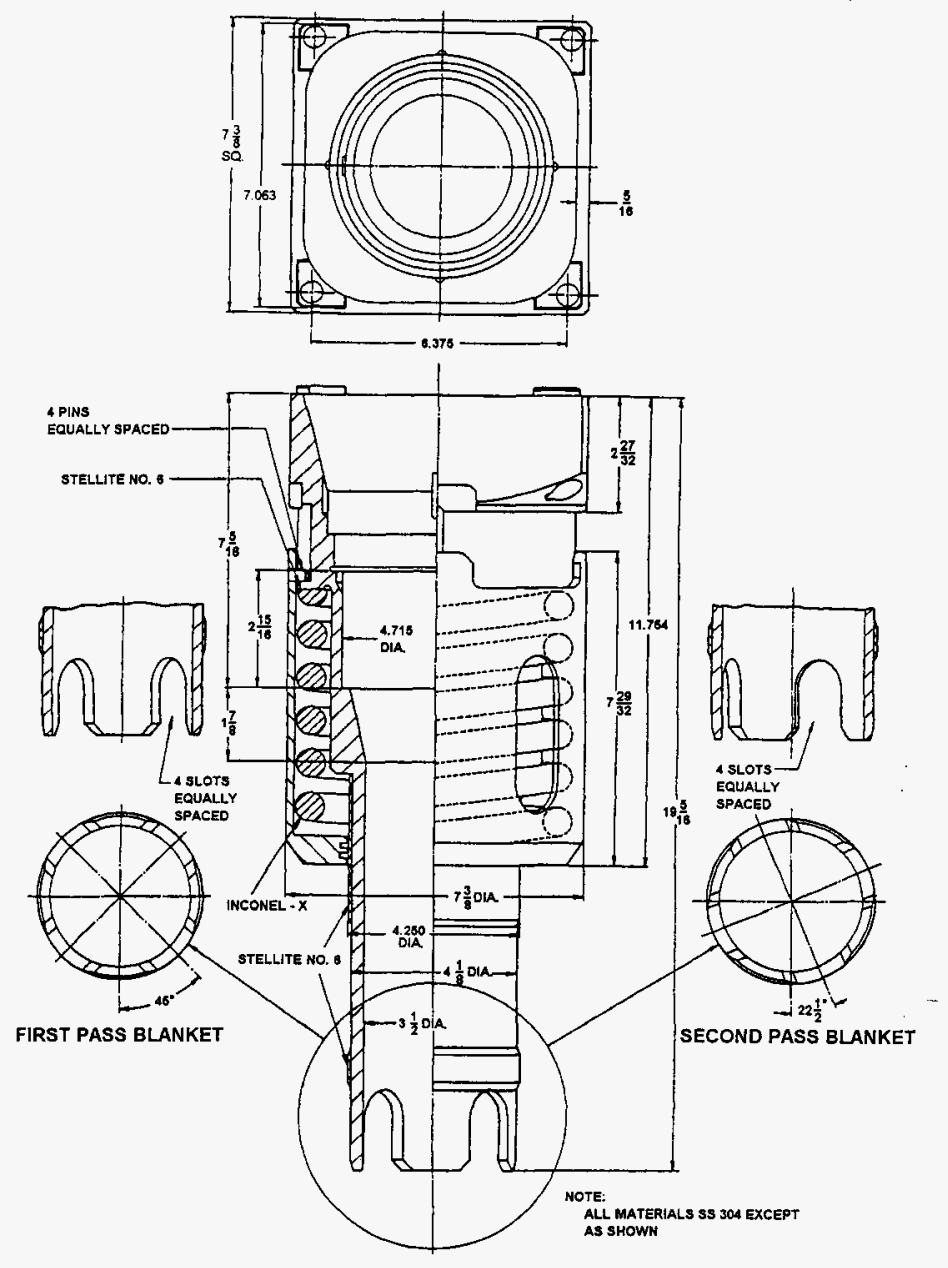


Each subassembly consists of 30 compartmented fuel plates and 2 zircaloy- 4 end plates welded together to form parallel coolant channels. The fuel plate design includes many small fuel wafers surrounded by a zircaloy-4 grid to provide adequate structural strength. The wafers have a pyrolytic carbon coating, which prevents the zirconium from reacting chemically with the uranium oxide. The upper and lower halves of the extended fuel cluster are mirror images.

The minor differences in the top and bottom stainless steel PWR-2 extension brackets are due to the two-pass flow arrangement used to optimize heat transfer in the reactor core. The top extension brackets are identical, except for the location of cooling water outlet passages. The location of these passages are dependent on whether they are second or first pass units (36 of both), as shown in Figure 6-2. In the first pass extensions, cooling water exits out of holes in the sides of the extensions. In the second pass extensions, the cooling water is forced out the top of the extensions. The bottom extension brackets are similar for first and second pass fuel assemblies, except for different key slots to prevent inserting an assembly into the wrong cooling water pass location.

The PWR-2 fuel assemblies are equipped with a variable orifice system (see Bettis drawing 922F432) used to control the cooling water flowrate through the fuel cluster. The variable orifice is located in the bottom extension with an actuating rod extending along the center line of the fuel cluster into the top extension. The actuating rod extends into the secondary locking unit, which is located in the top portion of the top extension. From this location, the coolant flowrate in individual fuel assemblies could be controlled without removing the assemblies from the reactor.

At the bottom of each PWR-2 fuel assembly top extension is a sampling rake for the Failed fuel Element Detection And Location (FEDAL) system. The cylindrical, stainless steel rake body has nine slots for passage of the main coolant flow. Inside the rake body are concentric passages for the sample flow, which enters through small holes drilled into the downstream face of the rake. The temperature of this mixed average coolant sample was measured by passing some of the sample through concentric tubes to the top of the blanket assembly. At this location the sample was directed past a thermocouple well and returned to the sample rack. Twenty of the blanket assemblies were modified (instrumented) to allow for cooling water temperature monitoring.

Eight of the 72 PWR-2 blanket assemblies are considered high burnup blankets with an average burnup of 24,538 MWD/MTU (Kelly 1975). These fuel assemblies were. located in the center of the reactor core. The remaining blanket assemblies had an average burnup of $15,236 \mathrm{MWD} / \mathrm{MTU}$. Therefore, the average burnup for all 72 blanket fuel assemblies is $16,200 \mathrm{MWD} / \mathrm{MTU}$. Table 6-2 gives PWR-2 fuel assembly radionuclide activity and decay heat for an average fuel assembly. 
Table 6-2. PWR-2 Fuel Assembly Radionuclide Activity and Decay Heat. ${ }^{1,2}$

\begin{tabular}{|c|c|c|c|c|}
\hline \multirow{3}{*}{ Nudiase } & \multicolumn{4}{|c|}{ Thro since horcto Eischarge } \\
\hline & 10 Years? & $20 \mathrm{year}^{2}$ & $\begin{array}{l}25 . \text { Years: } \\
19999 \%\end{array}$ & 30 Years \\
\hline & \multicolumn{4}{|c|}{ 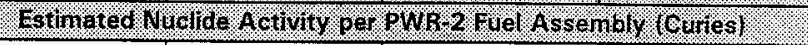 } \\
\hline${ }^{3} \mathrm{H}$ & 38.8 & 22.2 & 16.7 & 12.6 \\
\hline${ }^{55} \mathrm{Fe}$ & 1,510 & 105 & 27.8 & 7.32 \\
\hline${ }^{60} \mathrm{Co}$ & 1,050 & 281 & 146 & 75.5 \\
\hline${ }^{63} \mathrm{Ni}$ & 669 & 621 & 598 & 576 \\
\hline${ }^{85} \mathrm{Kr}^{3}$ & 399 & 209 & 151 & 110 \\
\hline${ }^{90} \mathrm{Sr}^{3}$ & 4,470 & 3,520 & 3,130 & 2,780 \\
\hline${ }^{90} Y^{3}$ & 4,470 & 3,520 & 3,130 & 2,780 \\
\hline${ }^{106} \mathrm{Ru}$ & 71.9 & 0.07 & 0.00 & 0.00 \\
\hline${ }^{106} \mathrm{Rh}$ & 71.9 & 0.07 & 0.00 & 0.00 \\
\hline${ }^{125} \mathrm{Sb}$ & 267 & 21.9 & 6.26 & 1.79 \\
\hline $125 \mathrm{mTe}$ & 65.2 & 5.34 & 1.53 & 0.44 \\
\hline${ }^{134} \mathrm{Cs}$ & 404 & 14.0 & 2.61 & 0.49 \\
\hline${ }^{137} \mathrm{Cs}$ & 8,980 & 7,130 & 6,350 & 5,660 \\
\hline${ }^{137 m} \mathrm{Ba}$ & 8,500 & 6,740 & 6,010 & 5,350 \\
\hline${ }^{144} \mathrm{Ce}$ & 11.0 & 0.00 & 0.00 & 0.00 \\
\hline${ }^{144} \mathrm{Pr}$ & 11.0 & 0.00 & 0.00 & 0.00 \\
\hline${ }^{147} \mathrm{Pm}$ & 1,120 & 80.0 & 21.3 & 5.69 \\
\hline${ }^{151} \mathrm{Sm}$ & 46.5 & 43.0 & 41.4 & 39.8 \\
\hline${ }^{154} \mathrm{Eu}$ & 517 & 231 & 154 & 103 \\
\hline${ }^{155} \mathrm{Eu}$ & 191 & 47.2 & 23.5 & 11.7 \\
\hline${ }^{238} \mathrm{Pu}$ & 274 & 254 & 244 & 234 \\
\hline${ }^{239} \mathrm{Pu}$ & 68.8 & 68.8 & 68.8 & 68.8 \\
\hline${ }^{240} \mathrm{Pu}^{3}$ & 93.2 & 93.3 & 93.3 & 93.3 \\
\hline${ }^{241} \mathrm{Pu}$ & 17,100 & 10,600 & 8,300 & 6,530 \\
\hline${ }^{241} \mathrm{Am}$ & 398 & 607 & 677 & 730 \\
\hline${ }^{244} \mathrm{Cm}$ & 197 & 135 & 111 & 91.8 \\
\hline Totals & $50,994.3$ & $34,348.88$ & $29,304.2$ & $25,262.23$ \\
\hline $\begin{array}{l}\text { Decay Heat } \\
\text { (Watts) }\end{array}$ & 136 & 104 & 95.8 & 89.2 \\
\hline
\end{tabular}

Notes:

1 Includes isotopes contained within extension brackets described in Table 6-3.

2 Bergsman (1994)

${ }^{3}$ Higher Activities for these nuclides are listed in (Hanson and Jackson 1978), but the basis is unavailable. These higher activities should be considered when significant to the application: ${ }^{a s} \mathrm{Kr}$ may be 40 percent higher, ${ }^{90} \mathrm{Sr}$ and ${ }^{90} \mathrm{Y}$ may be 50 percent higher, and ${ }^{240} \mathrm{Pu}$ may be 10 percent higher. 


\subsection{ESTIMATED RADIONUCLIDE CONTENT}

- The concentration of radionuclides present in the PWR-2 fuel assemblies is a function of the original fuel composition, irradiation history, and decay time. Short lived fission products have decayed to insignificant concentrations since the fuel ceased being irradiated in 1974. The radionuclide activity and decay heat of the fuel assemblies were determined by ORIGEN2 analysis based on the bulk composition and known operational history (Bergsman 1994). The activity and decay heat results are shown in Table 6-2 (shown on previous page) at 10,20, 25, and 30 years since irradiation. Specific information for the removable top and bottom stainless steel extensions of the fuel assemblies is shown in Table 6-3. Radionuclides that have decayed to less than 10 curies per assembly are not listed in these tables. The mass of the actinides in the fuel assembly cluster, shown in Table 6-4, has also been estimated by the ORIGEN2 analysis. Actinides with mass of less than 100 grams $(0.22 \mathrm{lb})$ per assembly have not been listed.

Table 6-3. PWR Stainiess Steel Extensions Radionuclide Activity and Decay Heat. ${ }^{\prime}$

\begin{tabular}{|c|c|c|c|c|}
\hline & & Thine Since Re & Dischiarge & \\
\hline Nuefore & 10984 & 20 Keans & $\begin{array}{l}25 \% \text { Yars. } \\
19991\end{array}$ & $80 \%$ Yars? \\
\hline & Esumated & do Activity oer & $\mathrm{h}_{2} \mathrm{Fuel}$ Asse & (CHins) \\
\hline${ }^{55} \mathrm{Fe}$ & 1,490 & 104 & 27.4 & 7.22 \\
\hline${ }^{60} \mathrm{Co}$ & 996 & 267 & 139 & 71.8 \\
\hline${ }^{63} \mathrm{Ni}$ & 669 & 621 & 598 & 576 \\
\hline Totals & 3,155 & 992 & 764.4 & 655.02 \\
\hline $\begin{array}{l}\text { Decay Heat } \\
\text { (watts) }\end{array}$ & 15.7 & 4.37 & 2.38 & 1.34 \\
\hline
\end{tabular}

Table 6-4. PWR-2 Fuel Assembly Actinides Mass.

\begin{tabular}{|c|c|c|c|c|}
\hline \multirow{3}{*}{ riglide } & \multicolumn{4}{|c|}{ The Since fieactor Discharge } \\
\hline & $\begin{array}{l}10 . \text { years } \\
19984 \text { ? }\end{array}$ & $\begin{array}{l}20 / \text { rears? } \\
(49941 \% \text {. }\end{array}$ & $25.79 a 19$. & $\begin{array}{l}30 \text { Yoars } \\
(20041\end{array}$ \\
\hline & \multicolumn{4}{|c|}{ 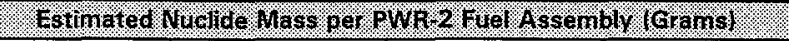 } \\
\hline${ }^{235} \mathrm{U}$ & 484 & 484 & 484 & 484 \\
\hline${ }^{238} \mathrm{U}$ & 219,000 & 219,000 & 219,000 & 219,000 \\
\hline${ }^{239} \mathrm{Pu}$ & 1,110 & 1,110 & 1,110 & 1,110 \\
\hline${ }^{240} \mathrm{Pu}$ & 409 & 409 & 409 & 410 \\
\hline${ }^{241} \mathrm{Pu}^{2}$ & 166 & 103 & 80.6 & 63.3 \\
\hline${ }^{241} \mathrm{Am}^{2}$ & 116 & 177 & 197 & 213 \\
\hline
\end{tabular}

Note:

'Bergsman (1994)

${ }^{2}$ Net loss in mass is due to radionuclide decay to isotopes that are not listed in the table. 
During discharge from the Shippingport reactor, some radioactive corrosion products (crud) adhered to the assemblies. The source was the reactor coolant with the assumed radionuclide activity coming primarily from cobalt-60 and iron-55. These isotopes have half-lives of 5.26 and 2.6 years, respectively. Further examination of "crud" is found in Section 6.7 .

\subsection{RADIATION LEVELS AND ESTIMATED HEAT OF DECAY}

\subsubsection{WHC Dose Calculations}

Table 6-5 shows the potential exposure rates associated with a single unshielded PWR-2 fuel assembly. These calculations were performed by WHC to determine if the assemblies were self protecting for security purposes as the assemblies are deemed self protecting if the exposure rate at $1 \mathrm{~m}(3.3 \mathrm{ft})$ is above $100 \mathrm{R} / \mathrm{hr}$. The calculations were undertaken by WHC using shielding code ISOSHLD-PC, Version 1.6. Radiation levels were calculated at contact and at distances of $1,2,3$, and $4 \mathrm{~m}(3.3,6.6,9.9$, and $13.2 \mathrm{ft}) \mathrm{from}$ the mid-plane of a single assembly.

Table 6-5. WHC PWR-2 Dose Rates.'

\begin{tabular}{|c|c|c|c|}
\hline \multirow{2}{*}{ Distrince } & \multicolumn{2}{|c|}{ 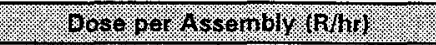 } & \\
\hline & 1978 & 1994 & (1: \\
\hline Contact $(5.08 \mathrm{~cm}[2 \mathrm{in.}])$ & 5,100 & & 3,200 \\
\hline $1 \mathrm{~m}(3.3 \mathrm{ft})$ & 220 & & 140 \\
\hline $2 \mathrm{~m}(6.6 \mathrm{ft})$ & 72 & & 45 \\
\hline $3 \mathrm{~m}(9.9 \mathrm{ft})$ & 35 & & 21 \\
\hline $4 \mathrm{~m}(13.2 \mathrm{ft})$ & 20 & & 12 \\
\hline
\end{tabular}

Note:

'Lourant (1991)

These dose rates are based on the radionuclide inventory determined at four years post-reactor shutdown (Hanson and Jackson 1978) and decayed to the appropriate year. The radionuclides were assumed to be uniformly distributed throughout the source geometry. The source was modelled as a rectangle with a height of $245.27 \mathrm{~cm}$ (96.56 in.), width of $16.99 \mathrm{~cm}(6.69 \mathrm{in}$.$) , and a length of 16.99 \mathrm{~cm}(6.69 \mathrm{in}$.$) . The source$ composition was uranium dioxide with an assumed density of $10.98 \mathrm{~g} / \mathrm{cm}^{3} \quad 1684.8$ $\left(\mathrm{b} / \mathrm{ft}^{3}\right)$. The outer cladding section of the assembly was modelled as a shield. The shield was assumed to be zircaloy- 4 with a thickness of $0.397 \mathrm{~cm}(0.156 \mathrm{in}$.$) and an assumed$ density of $6.66 \mathrm{~g} / \mathrm{cm}^{3}\left(415.4 \mathrm{lb} / \mathrm{ft}^{3}\right)$. The contact exposure was calculated at $5.08 \mathrm{~cm}$ $(2.0 \mathrm{in.})$ from the outer surface of the assembly.

The report Potential Exposure Rates from PWR Core /I Fuel Assemblies (Lourant 1991) stated that at the present rate of decay and with the stated assumptions, it has been determined that the exposure rates will be below $100 \mathrm{R} / \mathrm{hr}$ at $1 \mathrm{~m}(3.3 \mathrm{ft})$ from a 
single assembly following the year 1996. Recent calculations now estimate that the units will cease to be self-protecting in 2004 (McCormack 1996). Following this date the fuel will require additional protective measures to fulfill safeguards requirements.

\subsubsection{LATA Dose Calculations}

The previous information (for dose rate and decay heat) was extracted from the referenced WHC documents. To confirm these calculations, Los Alamos Technical Associates (LATA) conducted a series of calculations to estimate:

- Dose rate from a single unshielded PWR-2 fuel assembly

- Dose rate from four fuel assemblies within the T Plant Canister

- Dose rate from four fuel assemblies within the canister/Cask

- Decay heat versus time for a single fuel assembly

Mid-plane dose rates as a function of distance were calculated for the three dose rate configurations using the Standardized Computer Analyses for Licensing Evaluation (SCALE) software package. The results presented are preliminary and should be used for planning purposes only. Decay heat from a single PWR-2 fuel assembly was also calculated using the radionuclide inventory at various time intervals from reactor shutdown.

The fuel has been irradiated and thus contains both fission products and actinides. In addition, the top and bottom stainless steel extensions contain activation products (primarily iron-55, cobalt-60, and nickel-63) (see Table 6-3). Together, the fuel and the activated extensions form the source term used for calculating the dose rates and decay heat.

6.4.2.1 Radioisotopic Inventory. As stated in Section 6.3, an ORIGEN run was performed in 1991 to calculate the inventory following fuel discharge from the Shippingport reactor in 1974. This inventory was based on the SNF baseline burnup of $16,200 \mathrm{MWD} / \mathrm{MTU}$ (Bergman 1994). The highest burnup, however, was 24,000 MWD/MTU for eight of the PWR-2 fuel assemblies and therefore the inventory did not represent the worst or bounding case. For this analysis, the inventory calculated at 10 years from reactor discharge (equivalent to February 1984) was used as the initial isotopic content (see Table 6-2). The radioisotopic inventory was then calculated at $10.3,11,13,20$, and 22.9 years since reactor discharge (22.9 years is equivalent to January 1997$)$. These inventory intervals were used as the basis for the decay heat calculations whose results are discussed in Section 6.4.2.4.

6.4.2.2 Configurations Description. The geometric configurations used to represent the three fuel groupings (single assembly, 4 assemblies in a T Plant Canister, 4 assemblies in canister/cask) are shown on Figures 6-5, 6-6, and 6-7. The single fuel assembly was represented using a slab geometry and the four fuel assemblies for the T Plant Canister and canister/Cask configurations used a cylindrical geometry. In addition, the shielding effects of the T Plant Canister and the canister/Cask were also represented by a cylindrical geometry. 
Figure 6-5. Single Unshielded PWR-2 Fuel Assembly Dose Rate Locations. (Not to Scale)

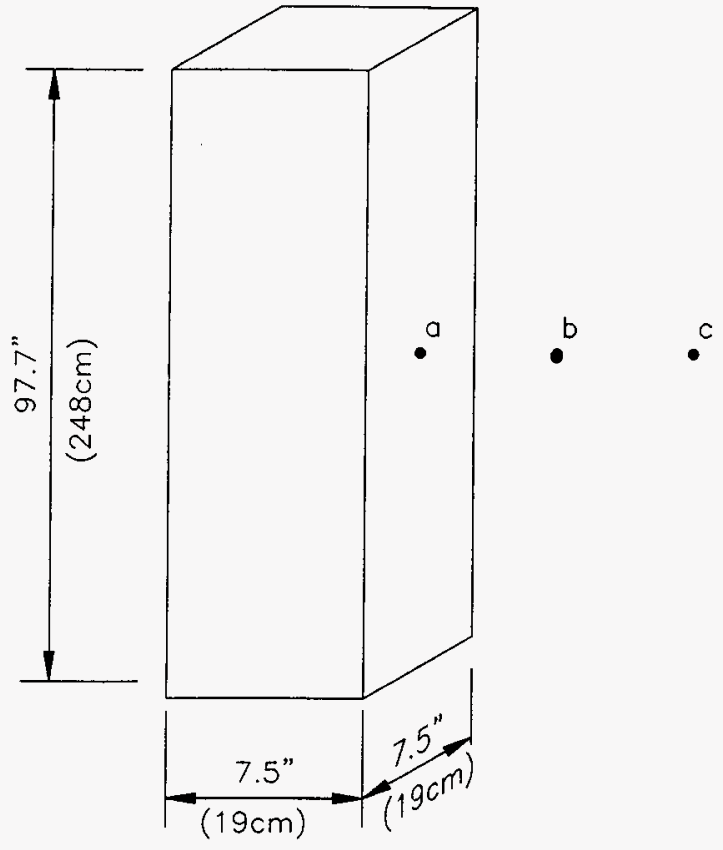

$d$

DOSE RATE LOCATIONS

$a=$ SURFACE
$b=1$ METER FROM SURFACE
$c=2$ METERS FROM SURFACE
$d=4$ METERS FORM SURFACE


Figure 6-6. T Plant Canister and Four PWR-2 Fuel Assemblies Dose Rate Locations. (Not to Scale)

QUTER RAD\| (FROM CENTER AXIS)

$\begin{array}{ll}\text { DIP PIPE } & .95^{\prime \prime}(2.41 \mathrm{~cm}) \\ \text { FUEL } & 7.94 "(20.18 \mathrm{~cm}) \\ \text { SPACERS } & 8.20 "(20.82 \mathrm{~cm}) \\ \text { WALL } & 12.00 "(30.48 \mathrm{~cm})\end{array}$
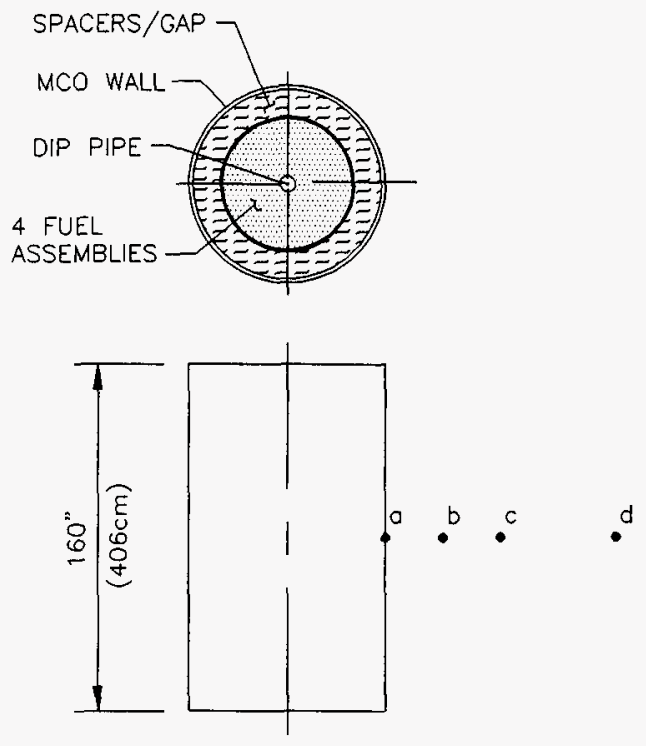

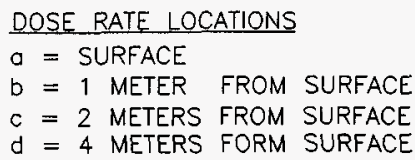


Figure 6-7. Cask/Canister and Four PWR-2 Fuel Assemblies Dose Rate Locations. (Not to Scale)

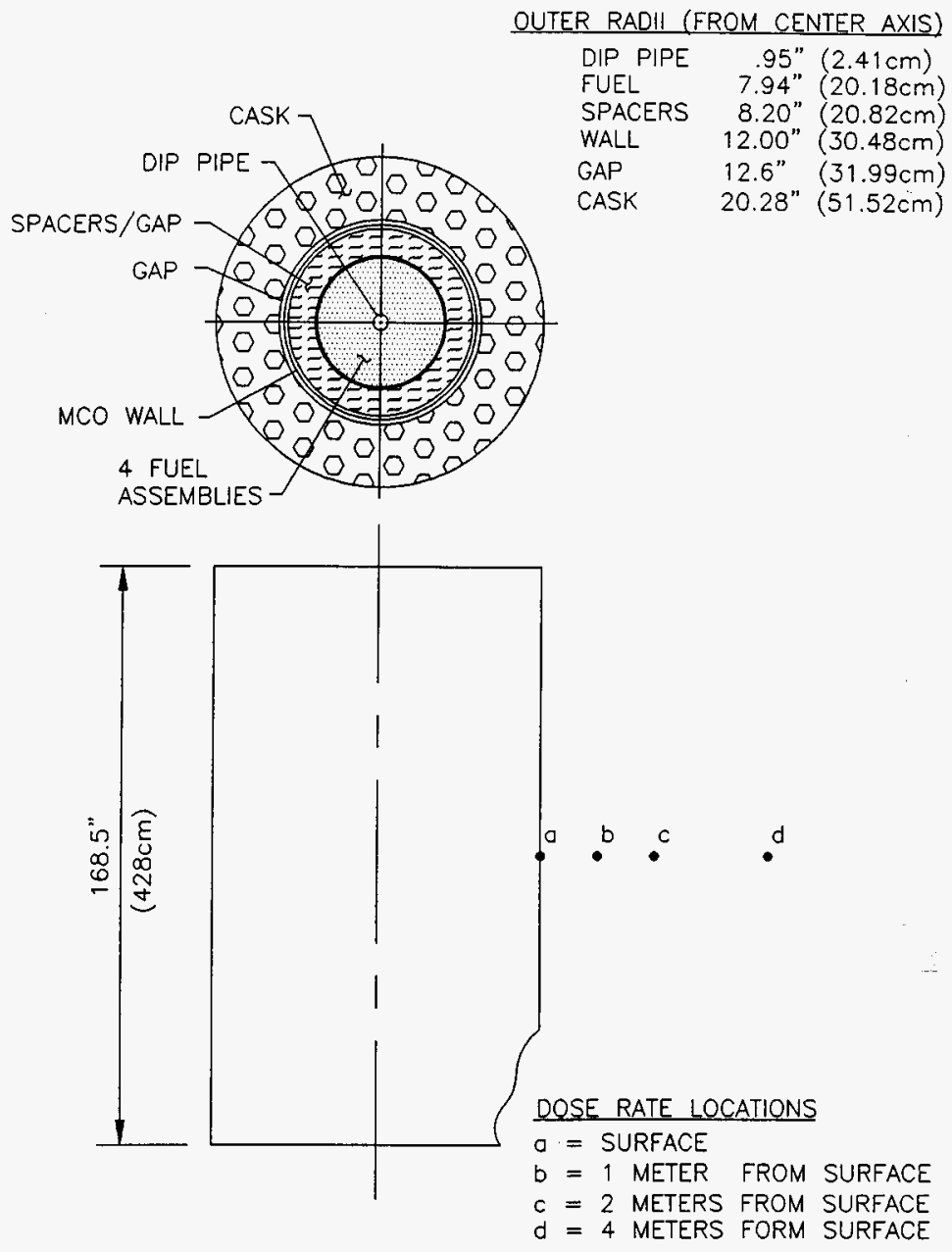


The radionuclide inventory was spread equally along the length of the fuel assembly. Recent calculations by WHC in which the cobalt-60 was located in the fuel assembly extensions indicated higher dose rates for the PWR-2 SNF compared to the $K$ Basin SNF. As stated in Section 6.4.2, these LATA calculations performed are "preliminary". More detailed calculations are required using a refined source term and more accurate geometry representing the final cask and canister design (see recommendation 3.3 ).

6.4.2.3 Dose Rate Results. Dose rates were calculated using the 1997 (average) inventory (22.9 years from reactor discharge) at the surface and three midplane distances from the outer surface of the three configurations. Only the photon (gamma) dose rates are reported. The results of the analyses are listed in Table 6-6. The calculations did not account for the neutron dose due to the curium-244 inventory, which is higher in the PWR-2 fuel assemblies than in the K Basin SNF.

Table 6-6. LATA PWR-2 Dose Rates (rem/hr) (January 1997).

\begin{tabular}{|c|c|c|c|}
\hline Pistance & Stinglev Unstielogd & 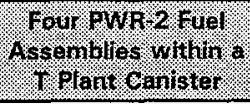 & 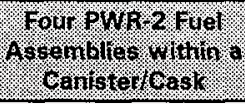 \\
\hline $\begin{array}{l}\text { Surface } \\
(0.16 \mathrm{~cm}[0.063 \mathrm{in.})\end{array}$ & 3,211 & 887 & 0.096 \\
\hline $1 \mathrm{~m}(3.3 \mathrm{ft})$ & 192 & 168 & 0.027 \\
\hline $2 \mathrm{~m}(6.6 \mathrm{ft})$ & 66 & 81 & 0.015 \\
\hline $4 \mathrm{~m}(13.2 \mathrm{ft})$ & 19 & 29 & 0.006 \\
\hline
\end{tabular}

6.4.2.4 Decay Heat Results. The decay heat for a single fuel assembly was calculated for each of the calculated decay intervals as reported in Section 6.4.2.1. The results of the analysis are:

Table 6-7. LATA PWR-2 Heat Decay.

\begin{tabular}{|c|c|}
\hline Hime Since Reactor prscharge / yearsl & 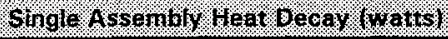 \\
\hline $10(2 / 84)$ & 137 \\
\hline 10.3 & 134 \\
\hline 11 & 131 \\
\hline 13 & 122 \\
\hline 20 & 104 \\
\hline $22.9(1 / 97)$ & 99 \\
\hline
\end{tabular}


6.4.2.5 Conclusions. Given the uncertainty in assumptions and the different software packages, the LATA calculated dose rates and decay heats are consistent with the 1991 WHC estimates presented in Tables 6-2 and 6-5. However as stated in Section 6.4.2, these LATA calculations are only preliminary. More detailed calculations, are required using a refined source term, monte carlo (or similar) code, and a more accurate geometry representing the final cask and canister design (see recommendation 3.3 and the note below).

NOTE - During the incorporation of final comments into this removal plan, the authors were informed that SNFP have produced new preliminary dose calculations for the PWR-2 fuel assemblies. In these new calculations, the cobalt-60 isotope is concentrated in top and bottom extension brackets and not spread throughout the assembly as in earlier assessments. Results from these preliminary calculations indicate dose rates from a filled (four PWR-2 fuel assemblies) canister/casks combination are higher than the earlier WHC and LATA assessments (Section 6.4) identified in this document. If these new assumptions and calculations, when completed and checked, indicate that radiation dose rates are likely to be higher than previously anticipated, a reevaluation of the process discussed in Section 7.0, will be required. It is considered likely that any increase in canister/cask dose rates will require the placement of temporary shielding around the canister/cask to protect workers during manual operations at the top of the cask (e.g., vacuum drying and lid sealing operations).

The scheduled delivery date of this removal plan does not allow for the completion and incorporation of the new dose rate calculations, which can take several months. Therefore, the plan has been issued based on existing dose rate calculations. However to resolve these radiation dose rate uncertainties, further analysis will be required to determine the effects of cobalt- 60 distribution and curium-244 neutron dose contribution and the effects of loading the canister with four fuel assemblies having a 24,000 MWD/MTU burnup. This further analysis would need to include the following.

- Recalculate (by background check and calculation) the radionuclide inventory used in this report (Section 6.3) and initiate new detailed dose rate calculations using Monte Carlo (or similar) code. These calculations are to use the most recent $K$ Basin MCO and transport cask designs and would analyze the radiation dose rate from one bare assembly and from four assemblies in the $T$ Plant Canister and cask. These calculations are to determine the dose from the fuel cluster and fuel assembly extensions separately. Dose rates emanating through the shield plug should also be examined.

- Perform real time dose measurements of a number of PWR-2 fuel assemblies within the T Plant storage pool using a newly calibrated instrument. Detailed dose measurements would be collected both around the fuel assembly top extensions and fuel clusters. Both surface measurements and measurements at a distance would be collected. To the extent possible, shielding effects of the pool water will be compensated for to give accurate dose measurements at distance. These measurements will confirm, or otherwise, the calculated radiation dose rate values. 
- If the new calculations and dose measurements indicate that actual radioactive dose rates are higher than those assumed in Section 6.4 then a reevaluation of the process discussed in Section 7.0, will be required. It is considered likely that any increase in canister/cask dose rates will require the placement of temporary shielding around the canister/cask to protect workers during manual operations around the top of the cask.

\subsection{PWR-2 FUEL ASSEMBLY CRITICALITY. (Miller 1978)}

The criticality information for the PWR-2 fuel assemblies is given in terms of the infinite multiplication factor $\left(k_{\infty}\right)$ for the blanket assemblies fully flooded with water at $25^{\circ} \mathrm{C}\left(77^{\circ} \mathrm{F}\right)$. Table $6-8$ lists $k_{\infty}$ values at the most reactive time during fuel irradiation.

Table 6-8. PWR-2 Fuel Assembly Criticality.'

\begin{tabular}{|c|c|}
\hline 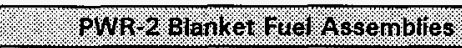 & 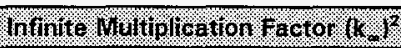 \\
\hline Unirradiated Blanket Assembly ${ }^{3}$ & 0.79 \\
\hline $\begin{array}{l}\text { Aggregate Blanket } \\
\text { Assembly (Average Burnup) }\end{array}$ & 0.89 \\
\hline $\begin{array}{l}\text { Most Reactive (High Burnup) } \\
\text { Blanket Assembly }\end{array}$ & 0.91 \\
\hline
\end{tabular}

Note:

1 Miller (1978)

${ }^{2}$ Even if all the fuel assemblies are assumed to be at the most reactive state, the effective multiplication factor $\left(k_{\text {etit. }}\right)$ of the assemblies will be less than 0.91 due to neutron leakage. The increase in the $\mathrm{k}_{\infty}$ factor is due to the production of plutonium isotopes during irradiation as shown in Table 6-4.

${ }^{3}$ Atherton (1968)

A more reactive criticality state could occur if the fuel was somehow separated from the zircaloy cladding and then arranged in the most favorable configuration. Such a change in state is not considered credible during transfer and T Plant Canister storage operations due to PWR-2 fuel assembly design and the controlled environment. In addition, dry storage of the PWR-2 fuel assemblies will lower the multiplication factor due to the lack of a moderator (water) and the subsequent increase in neutron leakage from the assemblies.

As stated in the referenced letter report (Miller 1978), "Based on engineering judgement, it is not possible to achieve a critical state by any known means other than addition of fissile material." Therefore, for the purposes of this plan it is assumed that no special precautions are required to protect the PWR-2 fuel assemblies from becoming critical and that this will be confirmed by a probablistic ris' safety analysis. 


\subsection{PHYSICAL CONDITION OF FUEL}

\subsubsection{Condition of Fuel Cladding}

A report issued on Shippingport operations during PWR-2 depletion (Atherton and Budd 1983) states, "Throughout core lifetime, the data from the defected element monitoring system indicated that no defects existed in any fuel element, a result confirmed by chemical analysis of primary coolant samples." Data obtained from the T Plant PWR-2 storage pool water sampling program (samples for cesium-137 as a primary indicator to detect fuel assembly breach) continues to support this conclusion (cesium-137 activity concentrations have remained constant at $-1 \times 10^{-6} \mu \mathrm{Ci} / \mathrm{ml}$ ), indicating that the fuel was not damaged during transportation to Hanford or during storage in the T Plant storage pool. It is assumed for the purpose of this plan that the fuel cladding is currently intact and will remain intact during transfers from the storage pool to the T Plant Canister.

\subsubsection{Fuel Assembly Bow}

A potential handling/canister containment problem may occur if PWR-2 fuel assemblies are significantly bowed over their length resulting in insufficient fuel assembly clearance within the T Plant Canister spacer basket. Bow represented here is defined as the permanent longitudinal deformation of a fuel assembly and when quantified is the maximum deformation from a line intersecting the two end points.

A Bettis report was issued in October 1987 entitled, Light Water Breeder Reactor (LWBR) End-Of-life Component Examinations At Shippingoort Atomic Power Station And Module Visual And Dimensional Examinations At Expanded Core Facility (Wargo 1987). The LWBR development program (Shippingport Core 3) used the same reactor vessel as the PWR Core 2 but subsequent to the removal of the PWR-2 fuel assemblies and using a different fuel assembly design. Table 6-9 defines the end-of-life LWBR fuel assembly bowing discovered during fuel element examination at the Bettis Expended Core Facility at Idaho National Engineering Laboratory. As information is not available on the end-of-life bow of PWR-2 fuel, a summary of results from the LWBR report are stated to illustrate potential PWR-2 bow.

Table 6-9. LWBR Maximum Fuel Assembly Bow.'

\begin{tabular}{|l|c|}
\hline $\begin{array}{l}\text { Seed Assembly } \\
(5 \text { examined } \times 318 \mathrm{~cm}[125 \mathrm{in.}] \text { long) }\end{array}$ & $0.15 \mathrm{~cm}(0.06 \mathrm{in})$. \\
\hline $\begin{array}{l}\text { Blanket Assembly } \\
(5 \text { examined } \times 318 \mathrm{~cm}[125 \mathrm{in.}] \text { long) }\end{array}$ & $0.30 \mathrm{~cm}(0.12 \mathrm{in})$. \\
\hline $\begin{array}{l}\text { Reflector Assembly } \\
(3 \text { examined } \times 318 \mathrm{~cm}[125 \mathrm{in.}] \text { long) }\end{array}$ & $0.64 \mathrm{~cm} 10.25 \mathrm{in})$. \\
\hline
\end{tabular}

Note:

1 Wargo (1987) 
A review of the anticipated canister, basket and 4 fuel assemblies configuration has concluded that a bow of up to $1.9 \mathrm{~cm}(0.750 \mathrm{in}$.) for each PWR-2 fuel assembly could be accommodated without difficulty. However, it is considered unikely that the fuel assemblies have bowed to this degree since there is no indication of diffjculty in their removal from the Shippingport reactor or transport flask.

\subsubsection{Confirmation of Dimensions}

The general overall dimensions and construction of a fuel assembly have been confirmed (except for overall length) by the physical measurement and examination of a disassembled, unirradiated PWR-2 fuel assembly previously stored at T Plant. Since the fuel assembly had been disassembled (top and bottom extension brackets removed and the fuel cluster extensions cut off), the exact overall length was not confirmed. However, various measurements of the top and bottom extension brackets and the width of the fuel cluster were taken and did confirm drawing dimensions. The unirradiated fuel assembly was shipped to Argonne National Laboratory for further study in April 1996.

As stated, it was not possible to confirm the overall length of the assembly, however it is assumed for this plan that the overall length of the PWR-2 assemblies is $3.615 \mathrm{~m}$ (142.314 ins) as shown on drawing number 921J962. This dimension is also indicated to be the overall PWR-2 fuel assembly length in the Bettis report PWR Core 2 Reactor Design Description Report (Atherton et al. 1968).

Prior to detail design and during the in-pool examination of the fuel assemblies (see recommendation 3.2 ) it is recommended that the overall length of a fuel assembly be confirmed in the T Plant pool using CCTV, a tape measure, and guide rod.

\subsubsection{Confirmation of Materials of Construction and Condition}

Westinghouse Bettis Atomic Laboratory Drawings 921J962, 921J987, 911F888, and 911 F381 are construction drawings of an overall PWR-2 fuel assembly, blanket fuel cluster, top extension bracket, and bottom extension bracket, respectively. These drawings provide assembly configuration, materials of construction, and dimensional information. Physical measurements of the unirradiated fuel assembly conform to the information presented on these drawings. Drawing $921 \mathrm{~J} 962$ also provides a drawing list for different components of the PWR-2 blanket fuel assemblies including the extension bracket bolts (Drawing 911B241). Drawing $911 \mathrm{~B} 241$ confirms the dimensions of these bolts and their construction from 304 stainless steel. A complete set of these PWR-2 blanket fuel assembly drawings are included in Appendix $D$.

Information on dimensions, materials of construction, storage pool water conditions and reactor heat loading/timescale were used for a metallurgical review of the PWR-2 fuel assemblies and bolts. The review concluded (memorandum from BNFL plc. dated 4/12/96, $4 / 19 / 96,7 / 5 / 96)$ that the present storage pool conditions do not provide a corrosive environment for either zircaloy- 4 or stainless steel. Zircaloy and stainless steel are compatible and any galvanic corrosion effect is unlikely. The purity and the low temperature of the storage pool water suggest that local corrosion effects such as chloride induced pitting corrosion are also unlikely to occur. In addition, the use of an iso-butyl 
alcohol/colloidal graphite bolt lubricant and the chrome plating of the assembly bolts will not promote stress corrosion cracking given the known reactor radiation fields and operating temperature.

See Appendix A for further details and discussion on construction, heat treatment, corrosion mechanisms, corrosion rates, and condition of the fuel assemblies.

\subsubsection{Plan Assumptions}

In view of the information presented above, the following plan assumptions have been made:

- The fuel assemblies are in good condition and can be handled using the top extension bracket without fear of failure (see this section and Appendix A).

- The fuel assemblies will not be bowed greater than $1.9 \mathrm{~cm}(0.75 \mathrm{in.})$ over their entire length thus aliowing placement of four assemblies in a canister.

- The fuel cladding has not been breached.

Confirmation of the condition of the PWR-2 fuel assemblies is important to the transfer process. Consequently, four fuel assemblies should be subjected to a video inspection for indications of failure and for determination of possible bowing using a gauge system. This would give some assurance that the condition of the fuel is as anticipated. Length measurements and crud examinations would also be performed during these inspections. This work would be conducted underwater in the T Plant storage pool.

In addition to the information presented in this section, Appendix A provides a detailed durability assessment of the fuel assemblies to determine if long term storage within the T Plant canyon is feasible and/or detrimental. The assessment reviews zircaloy cladding deterioration, stainless steel corrosion and sensitization, and the effects of storage pool water quality.

\subsection{CRUD BUILDUP ON FUEL}

Several Bettis reports have been produced reviewing the crud build-up on the PWR-2 fuel including the blanket assemblies. Crud is a corrosion product in the reactor coolant water that deposits onto the fuel during reactor operations. It is also caused by the formation of fuel element material corrosion products. The following information on crud deposits was extracted from two Bettis reports (Atherton and Budd 1983 and Hiliner 1980).

- Four fuel assemblies was calculated to be a representative sample for a confidence level of $95 \%$ assuming that the sampling result variance is equal to the desired confidence interval. 


\subsubsection{PWR-2 Fuel Assembly Interior Crud Characteristics. (Atherton 1983)}

After the replacement of seed 1 with seed 2 in 1969, one subassembly from the depleted seed 1 was selected for detailed examination of fuel element "crud" deposits on internal fuel plates. Two examination methods were utilized to determine crud characteristics. The first was photogrammetry measurements to determine crud thickness and roughness. The second was a de-scaling operation to determine crud elemental concentrations and activity. In addition, the crud concentrations and activity within the coolant water were also reported.

Photogrammetry Measurements. Photogrammetry measurements of crud thickness were made on the two ends of one of the interior fuel plates prior to de-scaling activities. The average crud thickness for the end regions was $0.0115 \mathrm{~cm} 10.00452 \mathrm{in}$.) with an average roughness of $3.411 \mu \mathrm{m}(134.3 \mu \mathrm{in}$.$) . Crud thickness for the mid-region was not present$ since there was no measurable amount of crud deposited in this area.

De-scaling Operations. Before de-scaling (removal of crud) operations began, the subassembly was divided into two units, one containing 14 fuel plates and the other containing 7 plates. Both of these units were individually de-scaled using a four-step sequential chemical de-scaling process. Analysis of the de-scale solutions from the two units are summarized in Table 6-10.

Table 6-10. PWR-2 Fuel Assembly Crud Compositions. ${ }^{1}$

\begin{tabular}{|c|c|c|c|c|c|c|}
\hline \multirow[t]{2}{*}{ Oomponent } & \multicolumn{3}{|c|}{ Surface cangentration } & \multicolumn{3}{|c|}{ Surface eorcentration. } \\
\hline & ( & 60 & 11 & $86-55$ & 00.60 & $4 \% 68$ \\
\hline $\begin{array}{l}\text { Unit } 1 \\
\text { (14 Plates) }\end{array}$ & 2.673 & 0.019 & 0.662 & - & 55.60 & 2.32 \\
\hline $\begin{array}{l}\text { Unit } 2 \\
\text { (7 Plates) }\end{array}$ & 1.197 & 0.006 & 0.428 & -- & 107.0 & 7.08 \\
\hline Weighted Average & 2.3 & 0.02 & 0.60 & - & 69.6 & 3.63 \\
\hline
\end{tabular}

Note:

Atherton (1983)

\subsubsection{Reactor Coolant Crud Characteristics (Atherton 1983)}

Table $6-11$ is a summary, by quarter years, of crud data obtained from weekly sampling of the PWR-2 reactor coolant water. Since the sample collection period was normally one complete week, the determined coolant crud concentrations represent an average for each week and did not reveal short-term peaking. Crud bursts (sudden increases in crud levels within the coolant) did occur following hydraulic shock or changes in system temperature or coolant chemistry. 
Table 6-11. PWR-2 Coolant Crud Concentrations and Activity. ${ }^{1}$ (2 sheets)

\begin{tabular}{|c|c|c|c|c|}
\hline 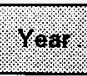 & Minarger & samples. & grudorompration nange & Specific A griwity A werage \\
\hline \multicolumn{5}{|c|}{ Seed $1-($ Core 2$)$} \\
\hline \multirow[t]{4}{*}{1965} & 1 & - & - & - \\
\hline & 2 & 12 & 3.78 to 32.8 & 2.74 \\
\hline & 3 & 13 & 2.28 to 18.1 & 5.25 \\
\hline & 4 & 5 & 1.25 to 16.3 & 8.46 \\
\hline \multirow[t]{4}{*}{1966} & 1 & 12 & 1.35 to 5.78 & 9.10 \\
\hline & 2 & 12 & 0.94 to 9.13 & 11.7 \\
\hline & 3 & 15 & 0.96 to 9.13 & 11.1 \\
\hline & 4 & 7 & 0.42 to 7.09 & 11.4 \\
\hline \multirow[t]{4}{*}{1967} & 1 & 15 & 2.80 to 8.30 & 12.4 \\
\hline & 2 & 13 & 3.17 to 13.6 & 21.5 \\
\hline & 3 & 14 & 1.14 to 14.4 & 28.1 \\
\hline & 4 & 15 & 2.33 to 15.3 & 29.2 \\
\hline \multirow[t]{4}{*}{1968} & 1 & 8 & 1.90 to 12.7 & 28.0 \\
\hline & 2 & 11 & 1.10 to 7.50 & 30.2 \\
\hline & 3 & 12 & 1.90 to 5.6 & 22.2 \\
\hline & 4 & 8 & 7.01026 & 38.9 \\
\hline 1969 & 1 & 9 & 3.0 to 40 & 34.4 \\
\hline \multicolumn{5}{|c|}{ Seed 2 - (Core 2) } \\
\hline \multirow[t]{2}{*}{1969} & 3 & 6 & 0.2 to 22 & 1.79 \\
\hline & 4 & 9 & 1.1 to 4.1 & 3.26 \\
\hline \multirow[t]{4}{*}{1970} & 1 & 11 & 0.66 to 3.00 & 3.30 \\
\hline & 2 & 8 & 2.77 to 4.37 & 3.28 \\
\hline & 3 & - & 2.36 to 7.07 & 1.68 \\
\hline & 4 & - & 1.81 to 10.53 & 2.24 \\
\hline \multirow[t]{4}{*}{1971} & 1 & 5 & 3.30 to 7.31 & 1.42 \\
\hline & 2 & - & 1.38 to 7.48 & 3.77 \\
\hline & 3 & - & 2.52 to 2.85 & 2.85 \\
\hline & 4 & - & 0.37 to 0.53 & 2.59 \\
\hline 1972 & 1 & - & 1.07 to 2.63 & 2.86 \\
\hline
\end{tabular}

Note:

'Atherton (1983) 


\subsubsection{Fuel Assembly Exterior Crud Deposits}

- There are assumed to be similar crud deposits on the exterior of the fuel assemblies as found on the interior fuel plates previously discussed in Section 6.7.1., however, no definitive information on thickness and activity has been found. When the multipurpose extended life blanket assembly was removed from the reactor vessel, it was first subjected to a visual examination. The second visual examination of the fuel plates occurred after the cladding surfaces were wiped clean with a clean cloth. "In general, all surfaces were found to have a uniform coating of crud which could be removed easily upon wiping with the clean cloth" (Hillner 1980).

\subsubsection{Crud Consequences}

It is probable that the PWR-2 fuel assemblies have a crud coating both internally and externally and that the crud, when removed from the storage pool, may fall from the fuel assemblies, causing contamination spread during fuel movements. Crud may also be discharged from the assembly during vacuum drying and may contaminate drying equipment. However, vacuum drying equipment will be equipped with High Efficiency Particulate Air (HEPA) filters on the discharge ports to eliminate contamination discharges to the environment.

During PWR-2 fuel transfer, care must be taken to protect surfaces from falling crud deposits (by laying removable coverings) and to protect the vacuum drying equipment from large fragments of crud (use of the $2 \mathrm{~mm}$ filter in T Plant canister). However, to quantify the amount of crud and its possible consequences, it is recommended that a minimum of four fuel assemblies are subjected to the following:

- Underwater video inspection of the fuel assemblies while using a scraper to disturb any crud on the assembly surface. This will indicate an approximate thickness, distribution, and quantity of any crud buildup. A sample of the crud would be collected and analyzed for content. If this inspection and analysis indicates significant crud problems a further review of crud consequences will be warranted.

For the purposes of this plan it is assumed that crud will not affect transfer since the fuel assemblies were successfully transferred into the storage pool in 1978 without noticeable crud problems.

\subsection{CHARACTERIZATION DATA PACKAGE}

The DOE Office of Spent Fuel Management has issued a memorandum titled interim Guidance for Protection of DOE Owned Spent Nuclear Fuel Data, dated February 5, 1996, which identified a major concern that SNF data needed for disposition may be lost or misplaced if action is not taken. The DOE Richland Operations Office Spent Nuclear Fuels Division has issued a memorandum (Spent Nuclear Fuels Records, E. D. Sellers to Director PNNL and President WHC, March 14,1996) stating that such records must be identified, reviewed and maintained for materials that satisfy the definition of SNF to ensure available information is retained. 
The DOE Office of Civilian Radioactive Waste Management (OCRWM) has issued a document identifying preliminary top level requirements for the potential acceptance of DOE SNF in a deep geologic repository. The document entitled Preliminary Requirements for the Disposition of DOE Spent Nuclear Fuel in a Deep Geologic Repository (DI:

A00000000-00811-1708-00006 Rev 001, identifies likeiy records and information that will be required for DOE SNF repository licensing and disposal.

As a consequence of these requirements, the provider of SNF for disposal will be required to issue a data package characterizing the SNF. The detailed requirements of this characterizing data package are to be fully defined at a later date but will include needed information for repository performance assessment and licensing. 
This page intentionally left blank. 


\subsection{PROCESS OVERVIEW}

This section details the operational processes and documentation. involved in the removal of the PWR-2 fuel assemblies from the T Plant storage pool, its transportation to the CSB, and storage of the fuel in the CSB Bay 1 storage tubes. A flow diagram of this process is shown in Figure 7-1.

\subsection{PWR-2 FUEL TRANSFER OPERATIONS}

\subsubsection{Documentation to Commence Operations}

Prior to the commencement of transfer operations, the following documentation (in addition to safety documentation and environmental permitting discussed in Sections 9.0 and 10.0 , respectively) will be required:

- Training manuals: Training manuals will be required for all aspects of PWR-2 transfer and transportation actions.

- Certification of training for operators: A training course to certify T Plant operators is required prior to commencement of transfer operations.

- Operational procedures: A complete set of operational procedures is required both to train operators and implement operational requirements.

- Permit to Work: A review of the permit to work system is required to confirm acceptability or identify modifications to the existing system.

- Health Physics (HP) procedures: A review of HP procedures is required to confirm acceptability or identify modifications to the existing system, for the movement of PWR-2 fuel.

- Acceptance documents to allow transport/cask/canister into T Plant: Acceptance documents are required to allow the transporter/cask/canister into T Plant. This document will confirm that the units are not contaminated above acceptable contamination levels and that the cask seals are in good condition.

- Canister/cask manifest document: This document will record the inventory of the T Plant Canister and will state the identification numbers of the fuel assemblies if obtainable during transfer. It will also state the contamination and radiation levels on the top of the open cask and the sealed T Plant Canister prior to fitting the cask lid. 


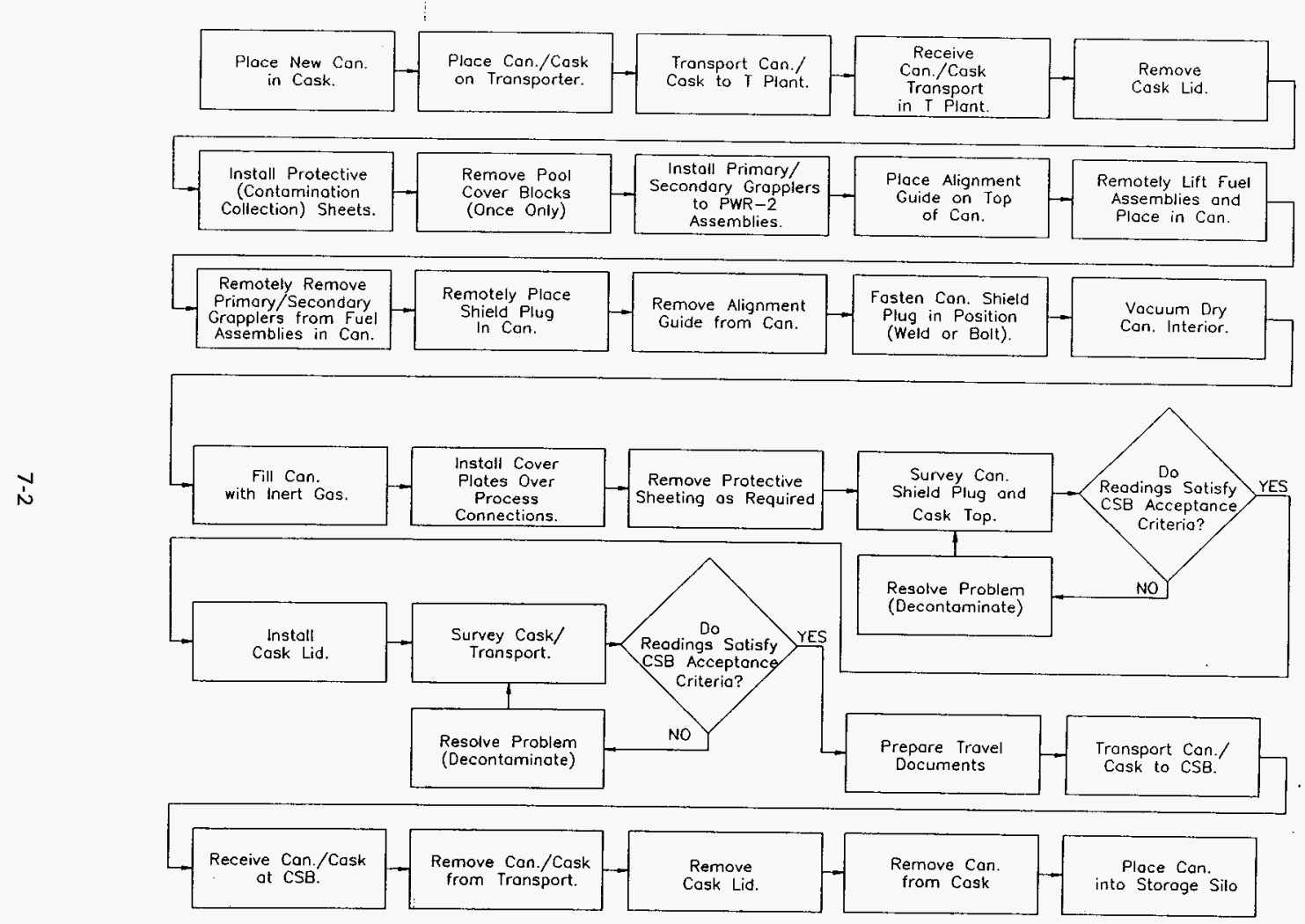


- Release certification to allow transport/cask/canister to leave T Plant: This certificate will record contamination and radiation levels on the outside of the cask and on the transport vehicle and verify that they are acceptable for movement outside the building. It will also verify that the cask lid seal has been proven effective and that the cask is secure on the transporter.

- Accountability records for transfer between Material Balance Areas.

- Completed spent nuclear fuel technical data package (see Section 6.8)

- Signed acceptance certificate allowing the transfer of the canister/cask to the CSB: Prior to movement of a PWR-2 fuel shipment from T Plant, a signed document is required stating that the particular shipment is acceptable to the CSB (radiologically and timescale).

- Maintenance manuals: A complete set of maintenance manuals is required to describe maintenance activities and confirm maintenance requirements.

- Maintenance procedures: A complete set of maintenance procedures is required both to train operators and confirm maintenance requirements.

- Certification of training for maintenance personnel: A training course to certify T Plant maintenance personnel is required prior to commencement of transfer operations.

- Crane and lifting equipment certification: All cranes and lifting equipment are to be tested and certified immediately prior to use for PWR-2 operations.

- Transfer documentation: The necessary documentation for the transfer of the PWR-2 fuel ownership from SWDD to SNFP.

\subsubsection{Training and Training Aids}

Certified training courses with training manuals will be required for all operations personnel prior to commencement of transfer operations. Training programs will be in accordance with Personnel Selection, Qualification, Training, and Staffing Requirements at DOE Reactor and Non-Reactor Facilities (DOE 1993a). Four simulated fuel assemblies, an canister/cask/transport system, and all grapplers and lifting equipment will be required for the training process.

This plan assumes that training will take place both in the classroom and in the $T$ Plant canyon. Canyon training will include trial runs of the actual removal process using the four simulated PWR-2 fuel assemblies. 


\subsubsection{Operational Readiness Review}

An ORR will be conducted on all PWR-2 transfer operations prior to commencement of operations. This review will demonstrate and document that a detailed review of operational readiness has been conducted and that all required documentation, training and equipment are complete and in place and that it is safe to commence transfer operations. The ORR will be conducted as per Start-up and Restart of Nuclear Facilities (DOE 1993e) and Planning and Conduct Of Operational Readiness Reviews (DOE 1993b).

\subsubsection{Place Cask/Canister in T Plant}

The cask/empty T Plant Canister combination is to be pre-positioned on the road transporter at the CSB with the canister basket perpendicular to the transporter to facilitate fuel loading. The canister shield plug will be positioned in its holder on the transporter and the cask lid will be bolted in place. The cask/canister combination will be fully secured on the transporter and any preparation requirements (e.g., pressure testing of the cask lid seals, etc.) completed. T Plant canister/casks will receive the same preparation requirements as $\mathrm{K}$ Basin $\mathrm{MCO} /$ casks, which are not yet defined. The canister shield plug is transported separately in its own container on the transporter. It is suggested that a reserve shield plug be placed in section 20 (far end of the canyon from the storage pool) so that in case the primary shield plug becomes damaged or somehow unusable, the reserve can be manually placed on the bridge crane and transferred to the canister.

Upon arrival at T Plant, the canister/cask/transporter will be backed down the access road to the railroad access tunnel. It will proceed through the rail tunnel roll-up door and will back along the rail access tunnel to the loading position. When the transporter combination is correctly positioned in the tunnel, the wheels will be blocked to prevent further movement. The transporter stabilization jacks will be lowered, positioned, and secured. The tractor unit will then be detached and removed from the rail tunnel. Following detachment of the tractor the transporter trailer is leveled.

\subsubsection{Prepare Cask/Canister}

With the transporter firmly secured and positioned, the cask lid will be removed using the T Plant bridge crane with the new 3 ton auxiliary hoist. (See Section 8.1.3.3 for functional requirements of the auxiliary hoist.) A power wrench will be provided (suspended from one of the existing one ton auxiliary hoists) for both the removal and tightening of the cask lid bolts. The cask lid is to be placed in a T Plant storage cradle during fuel transfer operations. Care will be taken to minimize cask lid and canister shield plug contamination during PWR-2 fuel loading operations. Both items will be covered with protective sheeting during fuel transfer operations. The exterior of the canister/cask/ transporter combination will also be wrapped in protective sheeting to simplify the removal of any radioactive contamination on their surfaces created during fuel assembly transfers.

A containment platform with guide rails will be established between the storage pool and the T Plant Canister. The platform will be covered with protective sheeting to simplify the removal of any radioactive contamination created during fuel assembly transfers from the storage pool to the T Plant Canister. 
Prior to fuel transfer, an alignment guide will be installed on top of the T Plant Canister to protect the top weld preparation of the Canister during fuel loading and to assist the crane operator in positioning and orienting the fuel assemblies and canister shield plug prior to insertion into the T Plant Canister. This guide is to be manually positioned on the canister prior to fuel transfer from the storage pool and removed after insertion of the canister shield piug into the T Plant Canister.

\subsubsection{Remove Fuel From Storage Pool}

Two options are considered for the removal of the fuel assemblies from the pool. Both options allow the manual connection (and manual conformation of connection) of the primary and secondary grapplers to the fuel assemblies under water. The first option is to purchase five primary and five secondary grapplers and manually connect (underwater using extension equipment) the grapplers to five individual fuel assemblies in the T Plant storage pool prior to fuel removal. The fifth fuel assembly, with connected grapples, is a spare in case one of the fuel assemblies cannot be transferred to the T Plant Canister. The primary grapplers locate in the lifting point built into the fuel assembly top extension brackets. The secondary grapples attach to a different lift point and are for backup should the primary grapple fail. The difficulty with this method is that each pair of grapples (primary and secondary) would require an umbilical control cord running back to the crane operator to enable release of the grapplers when the fuel is placed in the canister. This system must also be capable of remote reattachment of the grapplers within the $T$ Plant canister should a fault occur requiring the removal of the fuel from the canister and replacement back in the pool. The management of five umbilical cords may be problematic. An alternative option is to use a single pair of primary and secondary grapples requiring only one umbilical cord and have this permanently attached to the 10 ton $/ 3$ ton crane assembly. The use of a single pair of grapples would necessitate the insertion of the canister shield plug into the T Plant canister after each individual fuel assembly transfer. This would reduce the radiation dose rate and allow the operators to reenter the canyon and manually connect the grapples to the next fuel assembly to be moved. The 45-ton canyon bridge crane would be used to lift and move both the canister shield plug and the cask lid. The final choice of removal method will be determined during the detail design phase.

Operations using five pairs of grapples are outlined below. The use of a single pair of grapples will be similar.

7.1.6.1 Detail of Operations. The primary grappler is inserted into the top extension bracket of the fuel assembly and the four locking pins are manually extended and engaged. The secondary grappler is then manually attached to the top extension bracket and alf locking mechanisms activated. This operation is completed on five fuel assemblies. The design of the grapplers will enable remote connection to the 3 ton auxiliary hoist. The grapplers will have the capability to remotely connect and disconnect from the fuel assemblies in case of emergency. 
All fuel transfer operations from this point forward will be performed remotely by the canyon bridge crane operator from within the bridge crane cab until otherwise indicated. No personnel will be allowed on the canyon deck until the fuel transfer operation has been completed and the shield plug has been inserted into the T Plant Canister.

Following confirmation of the attachment and locking of grapplers onto the fuel assemblies, the 3 ton hoist is remotely connected to each of the grapplers in turn. A fuel assembly is lifted from the storage rack, out of the storage pool water, and to a position over the storage pool but away from other fuel. The fuel assembly is held stationary in this position for a period of time to allow surface water to drain back into the storage pool. When water ceases to fall from the assembly, it is transferred to the T Plant Canister. This operation is completed four times until the canister is filled. The canister shield plug is then positioned on the canister allowing personnel entry back into the canyon.

The highest risk associated with this retrieval process is during the transfer of each fuel assembly across the rail access tunnel to the T Plant Canister. During this period, the fuel assembly is suspended over a $9.1 \mathrm{~m}$ (30 ft) drop onto a concrete floor. If the grappler system and/or fuel assembly structure failed, the fuel assembly would fall to the floor of the rail tunnel and possibly roll under the cask transporter. Failure of the fuel assembly cladding is likely, causing the release of radionuclides into the tunnel and canyon. The use of a secondary grappler as described above is to mitigate the risk of falling fuel assemblies. If due to the risk a safety basis for fuel movements is difficult to establish then an alternative retrieval option, as discussed in Section 7.2, would be considered. However, during discussions, safety specialist were optimistic that an acceptable safety basis for these operation can be produced.

\subsubsection{Insert Fuel Into T Plant Canister}

Following transfer and lowering of the fuel assembly to the top of the T Plant Canister, it will be rotated to match the canister spacer basket. The fuel assembly is then lowered into the canister. Care will be taken to prevent the fuel assembly from becoming "hung-up" on the canister opening or on the top of the basket spacers. Once the fuel assembly has been inserted into the canister, it will be necessary to verify that the assembly is resting on the bottom of the canister. A marker line within the canister will confirm correct seating.

To comply with SNF accountability requirements each T Plant Canister will be uniquely numbered during manufacture. During fuel transfer operations the fuel assemblies will be viewed by CCTV and any identification numbers on the fuel will be recorded as being contained within a referenced canister. This information will be passed to the Safeguards and Material Control. (See Section 11.2 for further details.)

After insertion of each assembly into the T Plant Canister both the primary and secondary grapplers will be remotely released from the fuel assembly and placed in holding cradles. The bridge crane will continue this operation until all four fuel assemblies have been transferred to the canister. The process is illustrated in Figures 7-2 and 7-3. 
Figure 7-2. Elevation of PWR-2 Fuel Assembly Transfer.

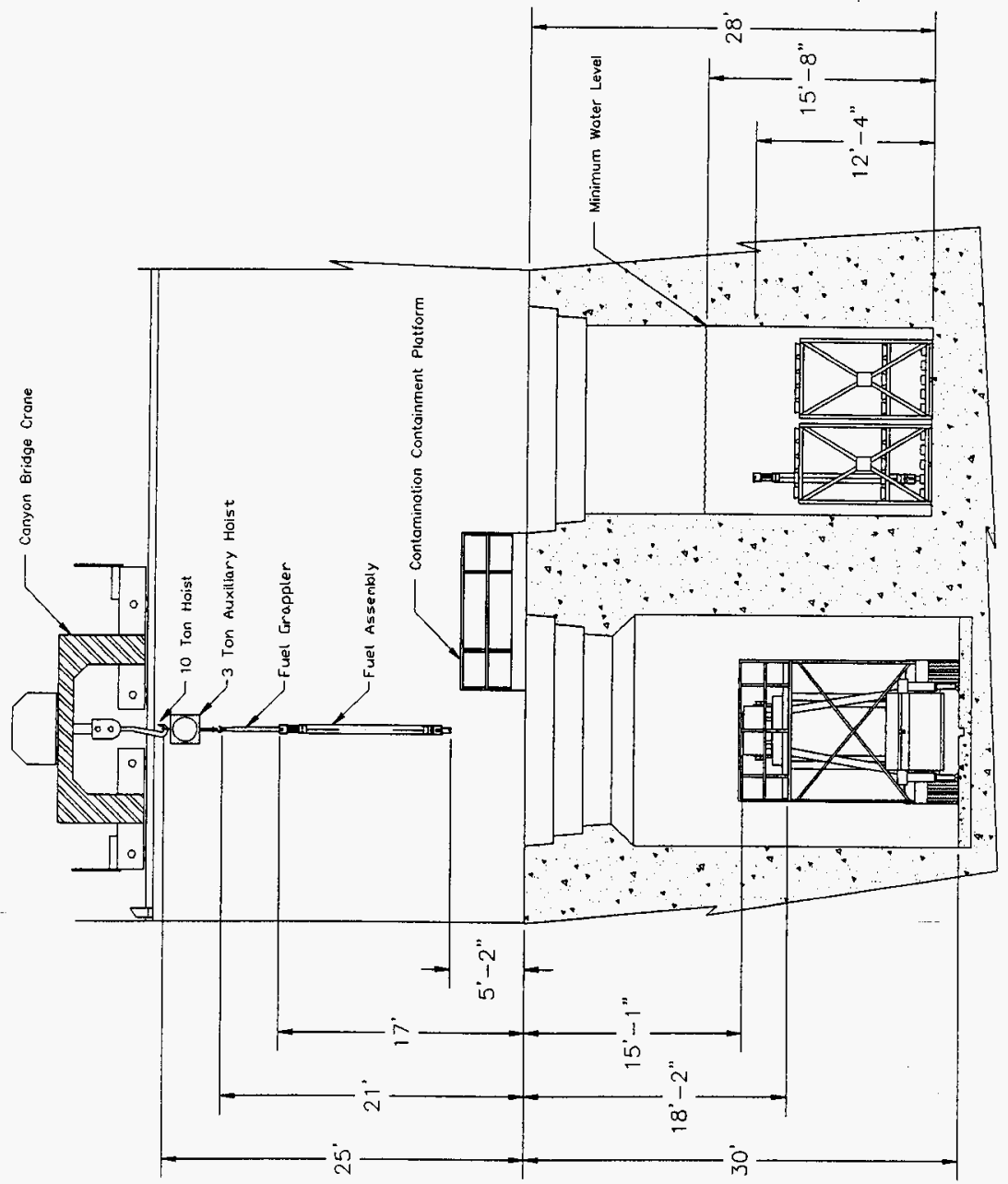


Figure 7-3. Plan View of PWR-2 Fuel Assembly Transfer

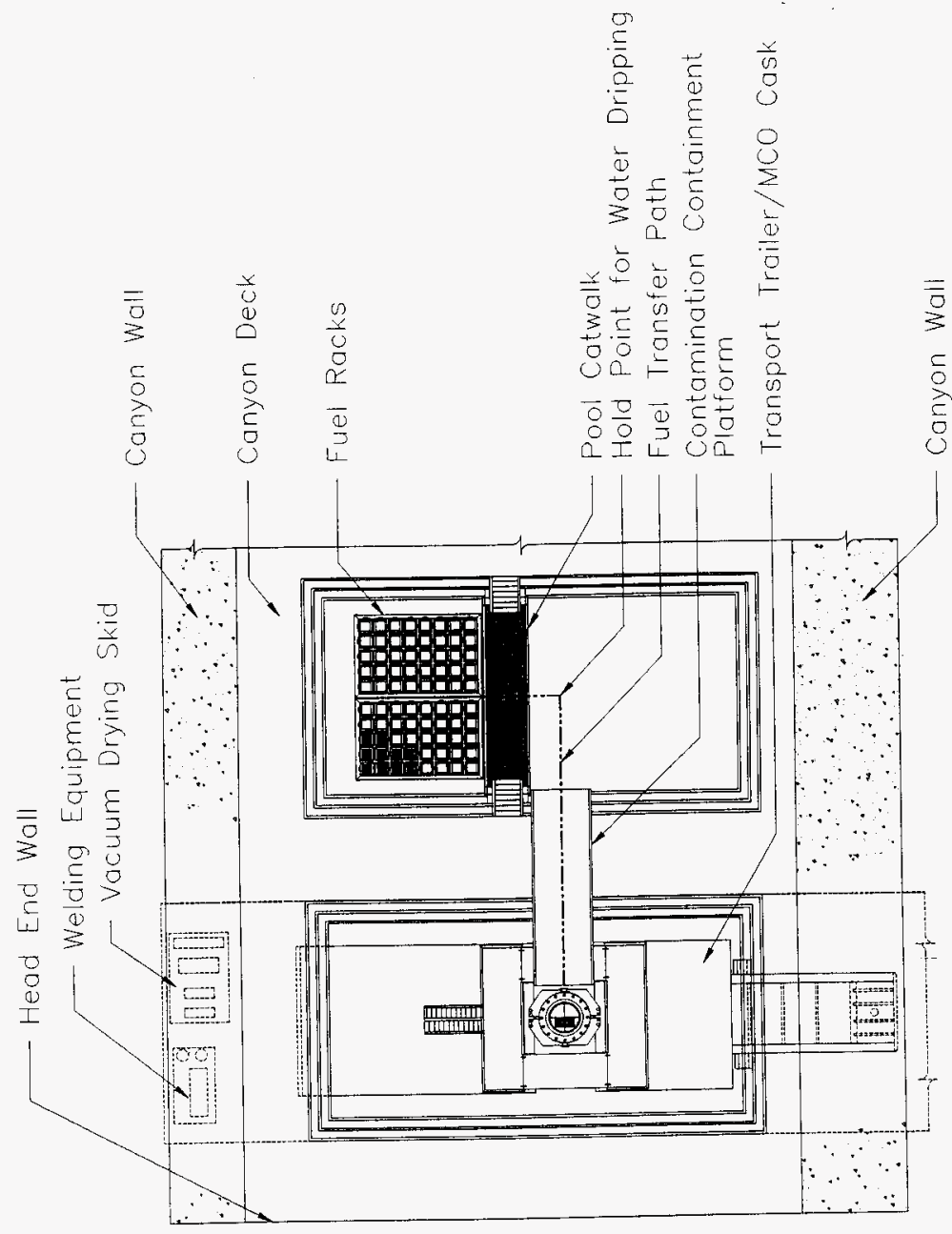




\subsubsection{Canister Shield Plug Insertion}

After transferring the fuel assemblies to the T Plant Canister, the shield plug is inserted into the T Plant Canister using the shield plug grappler and the 3 ton auxiliary hoist. The fuel assembly insertion guide will assist in the placement of the shield plug into the canister both to protect the top weld preparation and to stop the plug jamming at an angle in the canister top. It is assumed that this insertion requirement will be considered during the $\mathrm{K}$ Basin Title I and II design phases and that the same guide design and system of operation considered suitable for $\mathrm{K}$ Basin will be suitable (with minor modifications) for PWR-2 transfer operations.

Upon insertion of the shield plug into the T Plant Canister, operations personnel can reenter the canyon to complete transfer operations. This follows confirmation that the area radiation monitors are registering only normal background radiation levels and health physics technicians have checked the shield plug and cask top to ensure radiation levels are acceptable for manual operations.

\subsubsection{Sealing The Canister Shield Plug}

As described in Section 8.2, there are presently two options being considered by the $\mathrm{K}$ Basin design team for securing the shield plug to the MCO. These are:

- Welding the shield plug to the MCO immediately following SNF insertion.

- Initially bolting the shield plug in-place using a fastener ring. An encapsulating seal cover would be welded over the shield plug at the CSB.

Since the T Plant Canister will be of similar design to that used by K Basins, both options are considered here.

Welded Shield Plug (see Section 8.2.1). In this option an automated orbital welder, suspended from the auxiliary hoist, will be used to weld the shield plug to the canister body. It is assumed that the internals of the canister will be purged with an inert gas during welding to eliminate oxidation of the root weld and surrounding area. This method will require a non-destructive test on the root weld prior to completion of the weld. Confirmation of the quality of the root weld (probably a die penetration test) would require weld cleaning and manual inspection. The top of the cask and the gap between the cask and canister will require protection from the effects of weld splatter during any welding operations. Fire protection blankets and equipment will also be required.

Bolted Shield Plug (see Section 8.2.1). In this option the shield plug is placed within the canister and a screwed bolting ring is manually screwed in-place over the top of the plug. The screwed ring contains eight restraining bolts to pressure seal the shield plug to the canister using a metal pressure ring. The bolts are torqued to the appropriate level and feeler gauges used to ensure that the shield plug is completely seated within the canister body. After transfer of the filled canisters to the CSB the canister cover is welded over the shield plug, sealing the canister for permanent storage. 


\subsubsection{Vacuum Dry Canister}

.To remove any residual water from within the T Plant Canister, the internal volume of the canister will be vacuum dried before leaving the T Plant canyon. This plan assumes that this is accomplished by the use of skid mounted SNF vacuum drying equipment prepositioned within the canyon. (See Section 8.3 for details of vacuum drying equipment.) The canister will be connected to the vacuum drying equipment using quick connect couplings and hoses and will be dried until a vacuum of $4 \mathrm{mb}$ ( 3 torr) can be maintained within the canister for 60 minutes (or as directed by the CSB acceptance criteria). The outlet coupling will have an inline filter to protect the vacuum drying equipment from debris and crud from within the canister.

Approximately $8 \mathrm{~L}(2.1 \mathrm{gal})$ of pool water $(2 \mathrm{~L}$ [0.53 gal] per PWR-2 assembly) are assumed to be trapped within the top extensions of the four PWR-2 fuel assemblies. (This assumes that all four fuel assemblies within the T Plant Canister are of the first pass variety). An additional $4 \mathrm{~L}\{1.1$ gal) of residual water is assumed to be trapped within each fuel assembly and on the fuel assembly exterior, for a total liquid volume of approximately $12 \mathrm{~L}$ (3.2 gal). All evaporated water will be condensed and returned to the storage pool.

\subsubsection{Fill T Plant Canister With Inert Gas}

After vacuum drying operations have been completed, the interior of the T Plant Canister will be filled with an inert gas. This operation will be performed before the canister and cask leaves $\mathrm{T}$ Plant. After $\mathrm{T}$ Plant Canister inerting operations have been completed, the process connection cover plates will be bolted in-place on the shield plug in preparation for cask lid installation.

Following sealing, drying, and filling with inert gas, the T Plant Canister will be leak tested to confirm primary containment capability. The leak test rate land leak detection equipment) will be the same used for a $\mathrm{K}$ Basin $\mathrm{MCO}$ and is presently undecided. A figure of $1 \times 10^{-4}$ to $1 \times 10^{-5} \mathrm{scc} / \mathrm{sec}$ is being considered.

\subsubsection{Clean Area}

Following the completion of $\mathrm{T}$ Plant Canister leak detection tests, all temporary equipment and deck coverings will be checked for contamination in preparation for removal. After screening and decontamination of any hot spots, the temporary covers will be removed, contained, and disposed of as appropriate. The top of the canister and cask will also be decontaminated, if required, prior to the installation of the cask lid.

\subsubsection{Seal Cask}

The cask lid will be lifted from its storage area, placed in position on top of the cask body, and bolted in-place. The cask seal will be leak tested prior to transportation of the T Plant Canister and cask combination from T Plant to the CSB complex. It is assumed for this plan that cask sealing requirements and test equipment will be considered during the 
$K$ Basin Title I and II cask design phases and that the same design and system of operation considered suitable for K Basin casks will be suitable for PWR-2 transfer operations. The cask lid, after final sealing and leak testing, will be fitted with tamper-indicating devices.

\subsubsection{Confirm Cask is Suitable for Transportation}

Following sealing of the cask, the cask and transporter will be surveyed for contamination. Any contamination found will be removed or reduced to allowable limits prior to shipment. See Table 7-2 in Section 7.4.1 for allowable contamination on equipment going into the CSB.

DOE guidelines for the onsite transfer of SNF direct the use of 49 CFR 173.441 as criteria for radiation levels unless it is technically or economically infeasible to do so. The CFR states that the surface radiation levels on the outside of the cask should be checked and confirmed to be at or below $200 \mathrm{mrem} / \mathrm{hr}$. The dose rate $2 \mathrm{~m}(6.6 \mathrm{ft})$ from the edge of the transporter will need to be less than or equal to $10 \mathrm{mrem} / \mathrm{hr}$. The dose rate in any normally occupied space (e.g., drivers cab) of the transfer vehicle will be less than or equal to $2 \mathrm{mrem} / \mathrm{hr}$. The SARP (when written and approved) for the package and transportation of the cask will state allowable radiation levels and if any of the above values can be exceeded. All shipments of PWR-2 fuel assemblies will not exceed the SARP allowable radiation values. If measured radiation dose values exceed the SARP values, all work will stop and the situation evaluated.

\subsection{ALTERNATIVE RETRIEVAL OPTIONS}

The retrieval process described in Section 7.1 is considered to be the simplest engineering option available and is a similar process to that used for the placement of the PWR-2 fuel assemblies into the T Plant storage pool in 1978 and 1979. It is believed that an acceptable safety basis can be developed for this option (see Section 9.0). However, a potential difficulty in developing the safety basis for this preferred option is an accident scenario were a fuel assembly falls a maximum of $9.1 \mathrm{~m}(30 \mathrm{ft})$ onto the rail tunnel concrete floor. This could be caused by the failure of lifting equipment (crane/hoist/ grapple) or failure of a fuel assembly. Should this type of failure prove to be a major impediment in developing a suitable safety basis, the following options are available to minimize the drop height. The two options summarized below are typical of alternative transfer options that could be considered.

\subsubsection{Option 1 - Elevate Cask and T Plant Canister}

Description. In this option the canister/cask are elevated by placing them on a $6.1 \mathrm{~m}$ (20 $\mathrm{ft}$ ) high support platform built at the end of the rail tunnel. The height of the platform will ensure that the top of the T Plant Canister is $0.9 \mathrm{~m}(3 \mathrm{ft})$ above the canyon deck. A second, higher work platform is installed at deck level on all sides of the canister/cask. The functions of the top work platform are as follows. 
- Catch any falling fuel assemblies and prevent the assemblies from falling to the tunnel floor. This will minimize fall damage to the fuel assemblies and should reduce the release fraction used in the accident safety analysis.

- Provide operations personnel access to the top of the T Plant Canister and cask for sealing the shield plug, vacuum drying the fuel, and installing the cask lid.

- Simplify the recovery of fallen fuel elements. This would be difficult for the process described in Section 7.1.7 if a fuel assembly fell under the transporter or between the transporter and tunnel wall.

Process. The transporter/cask/canister would be positioned in the access tunnel and locked in position. A section of the transporter work platform would be removed and the cask anchors released. The 45 ton canyon crane, using a $\mathrm{K}$ Basin cask lifting yoke, would lift the canister/cask onto the support platform. The cask lid would be removed and the contamination catchment sheeting put into place. The fuel assemblies would be loaded into the T Plant Canister as previously described in Section 7.1, the shield plug inserted and sealed, and the fuel assemblies vacuum dried. The cask lid would be reattached and the filled cask lifted from the platform and placed back onto the transporter. The cask would be reanchored to the transporter and the transporter work platforms reinstalled. The canister/cask are then transported to the CSB as described in the previous sections.

Figures $7-4$ and 7-5 illustrate this option.

\subsubsection{Option 2 - Transfer T Plant Canister to Storage Pool}

Description. In option 2, the T Plant Canister (boited shield plug design only) would be placed in the T Plant storage pool prior to being loaded with PWR-2 fuel assemblies. A canister support structure would be constructed and placed in the west end of the storage pool. This structure would ensure that the canister remains in an upright position during loading. A flooded T Plant Canister would be submerged in the storage pool. After the canister is loaded with four fuel assemblies, the shield plug would be manually attached using extension tools. Additional descriptive criteria are as follows.

- Only one set of primary and secondary grapples are required. Grapplers can be manually installed and removed.

- Washing the T Plant Canister with clean water may not remove all contaminated pool water and cask internals may require decontamination after unloading the canister in the CSB. A potential problem may also exist if, following washing, the canister is still contaminated above the CSB acceptance levels. If this alternative option is chosen, additional study of how to decontaminate the canister exterior will be required.

- Only the canister design with a bolted shield plug allows easy use of this option as a fitted shield plug is required to lift and transport the canister. (The canister body has no lifting attachments. All grapple connections are built into the shield plug.) 
Figure 7-4. Alternative Retrieval Option One (Elevation View).

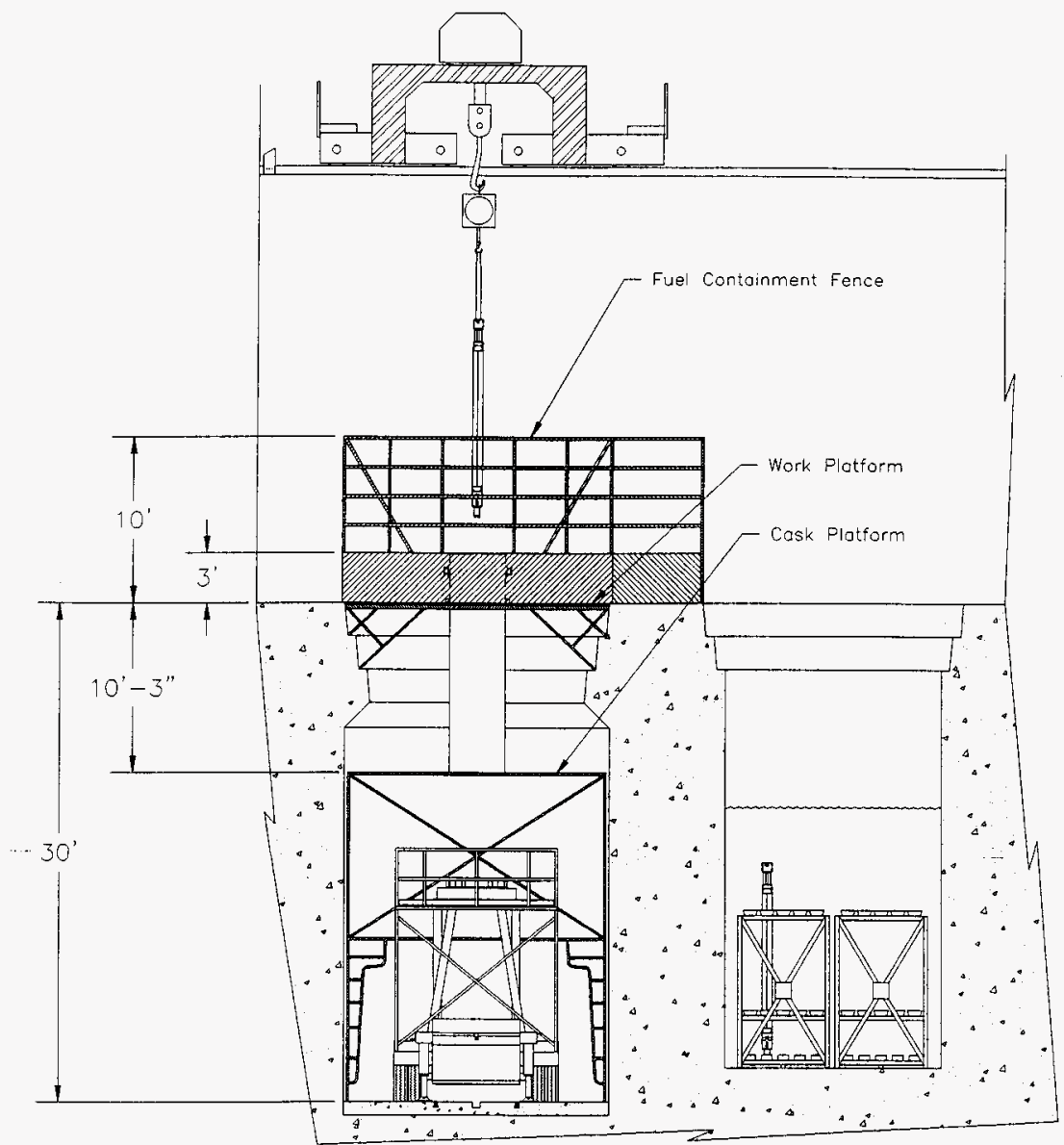


Figure 7-5. Alternative Retrieval Option One (Plan View).

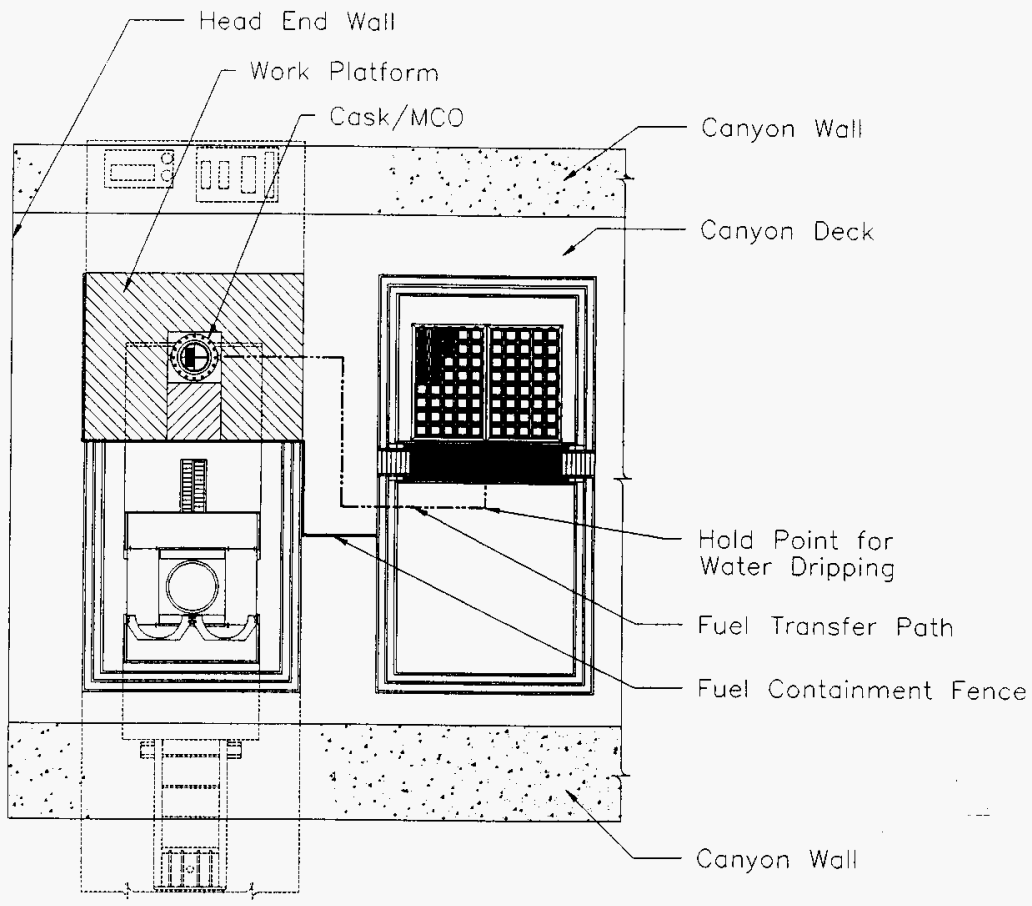


- This option simplifies the containment and recovery of fallen fuel elements. As fuel assemblies are loaded into the T Plant Canister in the storage pool, lifting equipment failure will result in a fuel assembiy falling only into the pool, limiting the potential fall and the resulting contamination release and providing radiation shielding for recovery operations.

- Since the T Plant Canister will be full of water, vacuum drying will be preceded by pumping the gross water from the canister. This will require the canister to have a dip tube fitted similar to the K Basin MCO. This will reduce the horizontal clearance inside the canister for the fuel assemblies from $1.9 \mathrm{~cm}(0.75 \mathrm{in.})$ to approximately $1.3 \mathrm{~cm}(0.50 \mathrm{in}$.$) .$

Process. The transporter/cask/canister is positioned in the access tunnel and locked in position. The cask lid is removed and the T Plant Canister (with a previously fitted, shield plug fastener ring) is filled with clean water. The filled canister is then lifted out of the cask using the canyon crane and canister grappler (attaching to the fastener ring). The canister is transferred to the T Plant storage pool and placed underwater into a canister support frame. The fastener ring would then be manually removed from the canister using long reach toois. Four fuel assemblies are loaded into the canister using the same design of primary and secondary grapplers as used in the original unloading operations in $1978 / 79$. The pool water, $1.2 \mathrm{~m}(4 \mathrm{ft})$, provides the necessary shielding during manual engagement and disengagement of the grapples. All fuel transfer operations are performed remotely with no personnel on the canyon deck.

After loading, the canister shield plug is lifted from its transporter frame (complete with seal) and is placed into the receiving socket in the top of the canister. The fastener ring is screwed back into place and the shield piug retaining bolts installed and tightened. See Figure 8.6 for details of the bolted shield plug canister. These operations will be carried out manually, underwater, using long reach tools.

When sealed the canister is lifted from the pool water and held stationary to allow water to drain from the canister exterior. Using an automated system, the exterior of the T Plant Canister is then pressure sprayed with clean water to remove residual contamination (as best achievable). Following completion of the pressure wash, the canister is placed back into the transport cask. The bulk water within the canister is removed and pumped back to the storage pool and the fuel assemblies vacuum dried. After filling the canister with an inerting gas and final sealing of the canister, the cask lid is reinstalled and the fuel assemblies transported to the CSB. Figure 7-6 illustrates this option.

\subsection{TRANSPORTATION TO CANISTER STORAGE BUILDING}

During discussions with WHC's Safeguards and Accountability (including Security) department and ICF Kaiser's transportation department, the consensus was to move the PWR-2 fuel assembly shipments during the spring/summer/autumn timeframe to limit damage to the roads during winter caused by movement of overweight vehicies and to minimize accidents caused by ice. Security preferred that the fuel assembly movements occur Monday to Friday during normal working hours. The transfer schedule will assume these preferences are followed. 
Figure 7-6. Alternative Retrieval Option Two (Elevation View).

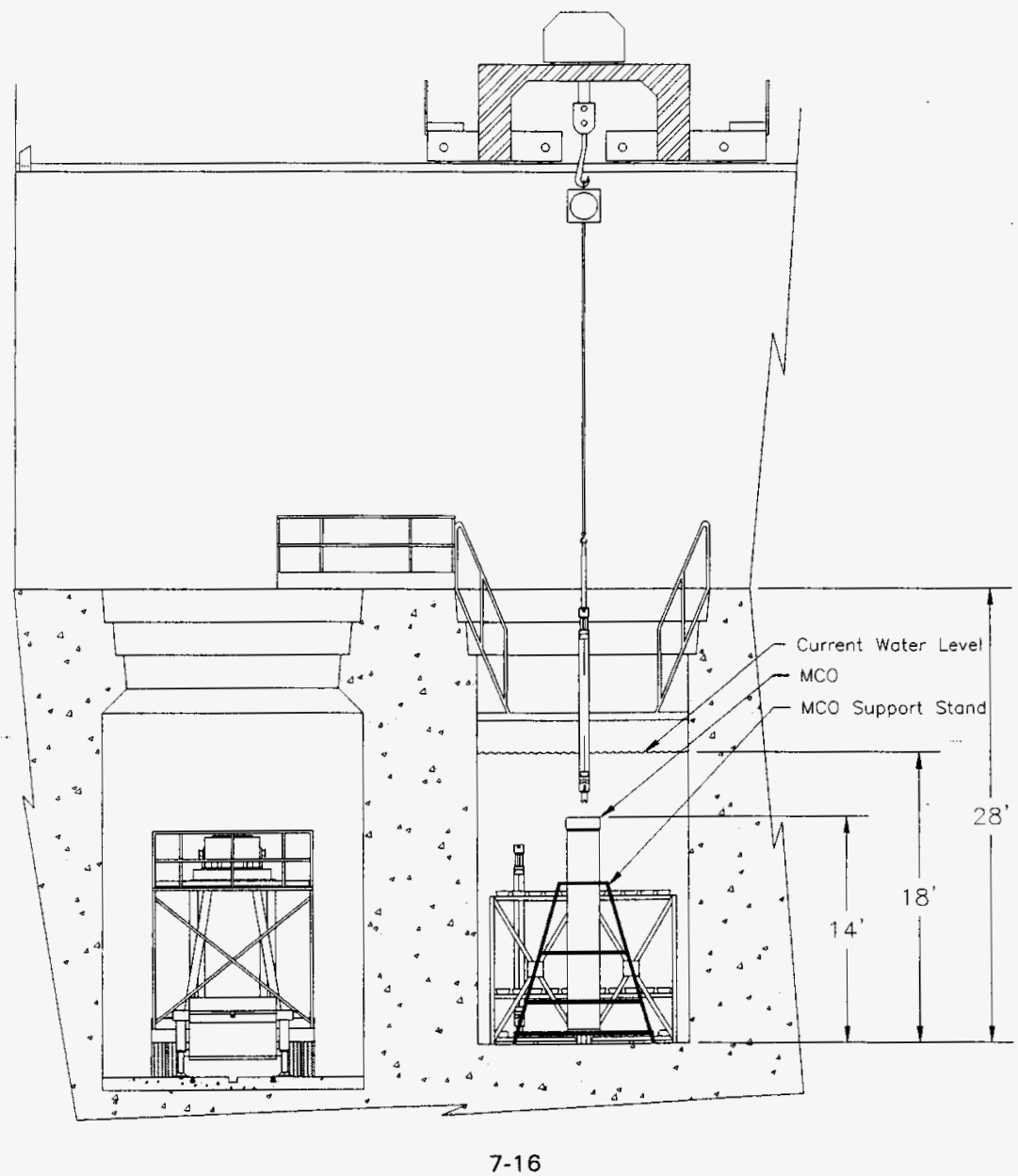




\subsubsection{Transport Documentation}

The following transportation documentation is assumed to be required prior to shipment of the PWR-2 fuel assemblies from T Plant to the CSB.

- Canister/cask manifest document: This document will record the inventory of the T Plant Canister and will state the identification numbers of the PWR-2 fuel assemblies if obtainable during recovery. It will also state the contamination and radiation levels on the top of the open cask, including the sealed $T$ Plant Canister, prior to fitting the cask lid.

- Release certification to allow transport/cask/canister to leave T Plant: This certificate will certify that contamination and radiation levels on the outside of the cask and on the transport vehicle are acceptable for movement outside the building. It will show that the cask lid seal has passed inspection and that the cask is secure on the transporter.

- $\quad$ Signed acceptance certificate allowing canister/cask into CSB: Prior to movement of a PWR-2 fuel assembly shipment from T Plant, a signed acceptance certificate is required from the CSB stating that the particular shipment can be immediately accepted at the CSB.

- An approved SARP: As stated in Section 9.0, an approved SARP is required prior to any SNF shipments.

- An approved transportation procedure: An approved transportation procedure detailing afl transportation processes will be required prior to any PWR-2 shipments.

\subsubsection{Proposed Transport Equipment}

The use of a canister design similar to the MCO designed for K Basin SNF containment will facilitate the use of the same transport cask and trailer design for SNF transport from T Plant to the CSB. The current $\mathrm{K}$ Basin transport proposal includes a transport cask with a work platform mounted on a $12.1 \mathrm{~m}$ (40 ft) double drop trailer. For details of this equipment see Sections 8.4 and 8.5 .

\subsubsection{Transport Route}

The proposed route for transport of the PWR-2 fuel assemblies from T Plant to the CSB will provide for the safe transport of fuel. The definition of a safe transport route is a route that will provide the necessary requirements to ensure that all persons, equipment, and the environment are free from all undue risk of harm due to the size, weight, and radiological characteristics of the transport. This plan assumes the proposed route shown in Figure 7-7 will be used and meets the stated definition. 
Figure 7.7. Transfer Route for PWR-2 Fuel Assemblies from T Plant to CSB.

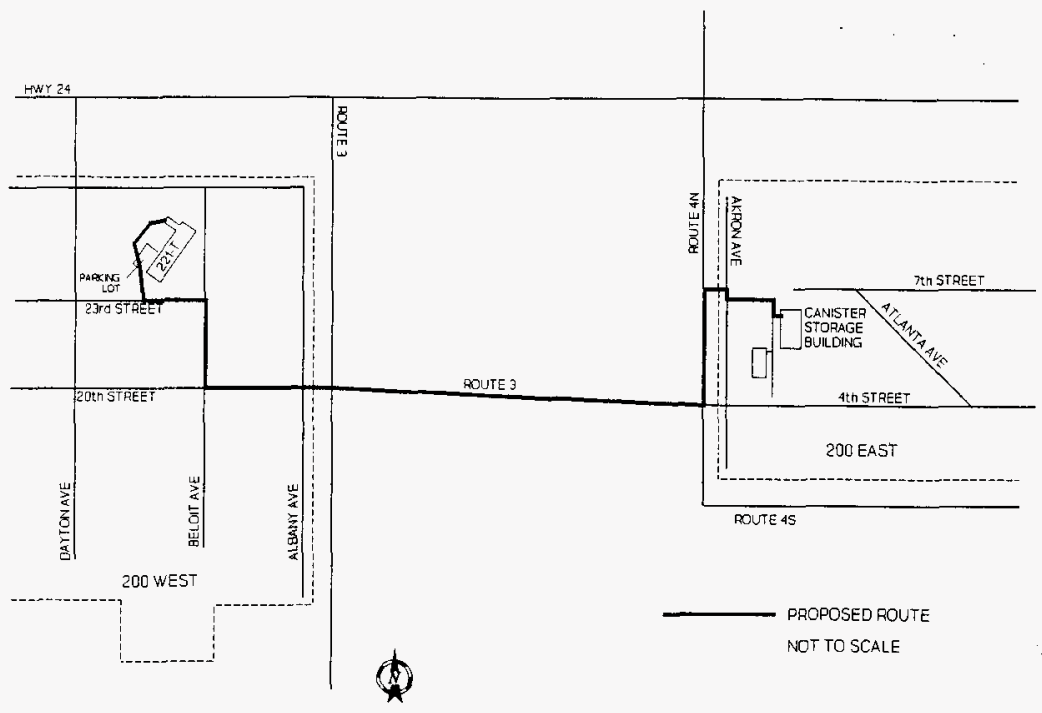

7.3.3.1 Safety Equipment. The transport will be equipped with necessary equipment to warn all persons who might interact with the transport or the transport contents. The transport will also carry signs and markings capable of warning other drivers about the size of the transport (an oversize permit is required for these shipments). The following are a summary of the Hanford Site overweight permitting requirements outlined in the transportation section of the Hanford information section on the Hanford Local Area Network.

Signs. Oversize load signs lat least $2.1 \mathrm{~m} \mathrm{[7} \mathrm{ft]} \mathrm{long} \mathrm{and} 46 \mathrm{~cm}$ [18 in.] high with black lettering at least $25 \mathrm{~cm}$ [10 in.] high in $3.8 \mathrm{~cm}$ [1.5 in.] brush stroke on yellow background) will be mounted on the front of the towing vehicle and on the rear of the load or trailing unit. The signs are to be displayed only when the unit is in transit and must be removed or retracted at all other times.

Flags. All flags will be clean, bright red flags at least $30 \mathrm{~cm}(12$ in.) square. They will be displayed so as to wave freely on all four corners of overwidth vehicles. 
Escort car requirements. The site transportation department will determine if escort cars are necessary for these shipments. This will be determined at the time of application for the oversize/overweight permit. It has been agreed with the security department that a security escort is not required for shipments of PWR-2 fuel assemblies from T Plant to the CSB.

Communication. Both the transporter and all escort vehicles will have two-way radio capabilities, adequate to provide communications between drivers at all times during which the oversize unit is in motion.

7.3.3.2 Physical Characteristics of Route. The proposed route for transport of the PWR-2 fuel assemblies to the CSB is shown in Figure 7-7. The transporter will be loaded in the 221- $T$ access tunnel at $T$ Plant. When the transporter leaves the access tunnel, it will head up the tunnel access ramp and will continue down the northwest access road (unimproved) that parallels the canyon building (see Figures 8-10 and 8-11). This plan assumes that the track will be upgraded (See Section 8.5 ) and paved prior to use as part of the PWR-2 transport road system. The access road connects with the west parking lot at $T$ Plant, which will allow the transporter access to $23^{\text {rd }}$ Street.

Hanford Area Utilities. The plan assumes that all utilities (e.g., steam, water, electrical, sewer, etc.) that pass below or above the proposed route can accommodate the weight and size of a fully loaded cask/transporter. If the transport weight or size is beyond the design limitations of any of these utilities the interfaces will be upgraded.

This plan does not contain a detailed evaluation of the transport route/utility interfaces. However, brief route discussions with the ICF Kaiser Site Services department did not identify any major problems. It is recommended that additional study be performed prior to selection of the final transfer route.

Railroads. The transport of the PWR-2 fuel assemblies will require several railroad crossings. The plan assumes that the loaded transporter can cross all railway crossings without problems. These crossings will be coordinated with Hanford Site railroad operations, including the use of the rail tunnel at T Plant.

Canister Storage Building. The transport of the PWR-2 fuel assemblies must be coordinated with the CSB. Before transport can commence, the CSB must be contacted and verification given that the CSB is ready to receive the shipment (shipping papers, etc.). $T$ Plant will coordinate with the CSB and determine a schedule for deliveries of canisters/casks for T Plant operations.

\subsection{CANISTER STORAGE BUILDING - RECEIPT OF PWR-2 FUEL ASSEMBLIES}

\subsubsection{Canister Storage Building - Criteria for Acceptance}

The CSB does not as yet have a formal Criteria for Acceptance for PWR-2 fuel shipments. Table 7-1 provides the assumptions used for PWR-2 fuel assembly retrieval, pending clarification. Table 7-2 provides known CSB external contamination limits. 
Table 7-1. Assumed CSB/PWR-2 Fuel Assembly Detailed Acceptance Criteria.

\begin{tabular}{|c|c|}
\hline Activity & $\begin{array}{l}34,000 \mathrm{Ci} / \text { Fuel Assembly (See Table 6-2 } \\
\text { for individual isotope activities) }\end{array}$ \\
\hline Fuel Drying and Inerting & $\begin{array}{l}\text { Fuel will be Cold Vacuum Dried until a } \\
\text { vacuum of } 3 \text { torr can be maintained for } 1 \\
\text { hour. Following cold vacuum drying an } \\
\text { inerting gas will be placed in the cylinder }\end{array}$ \\
\hline $\begin{array}{l}\text { Dose Rates (4 PWR-2 Fuel Assemblies in a } \\
T \text { Plant Canister) }\end{array}$ & $900 \mathrm{rem} / \mathrm{hr}$ (Surface) \\
\hline Decay Heat & $\begin{array}{l}400 \text { watts } / \mathrm{hr} / \mathrm{T} \text { Plant Canister }(100 \\
\text { watts } / \mathrm{hr} / \text { Fuel Assembly })\end{array}$ \\
\hline Filled T Plant Canister Weight & $\begin{array}{ll}\text { Four Fuel Assemblies } & 2,150 \mathrm{~kg}(4,720 \mathrm{lb} .) \\
\text { Empty Canister } & 1,250 \mathrm{~kg}(2,750 \mathrm{lb} .) \\
\text { Total } & 3,400 \mathrm{~kg}(7,470 \mathrm{lb} .)\end{array}$ \\
\hline Primary Containment Confirmation & $\begin{array}{l}\text { The T Plant Canister will be filled with an } \\
\text { inert gas and will be pressure tested to } \\
\text { confirm primary containment capability. } \\
\text { The type of inerting gas and the test } \\
\text { pressure to be acceptable to CSB. }\end{array}$ \\
\hline Contamination Levels & Will not exceed those stated in Table 7-2 \\
\hline
\end{tabular}


Table 7-2. CSB External Contamination Limits

\begin{tabular}{|c|c|c|}
\hline (2. & 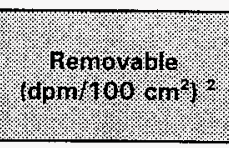 & 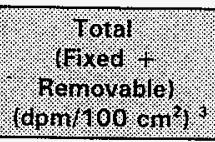 \\
\hline $\begin{array}{l}\text { U-Natural, }{ }^{235} \mathrm{U},{ }^{238} \mathrm{U} \text {, and associated decay } \\
\text { products }\end{array}$ & 220 alpha $^{4}$ & 5,000 alpha \\
\hline $\begin{array}{l}\text { Transuranics, }{ }^{228} \mathrm{Ra},{ }^{228} \mathrm{Ra},{ }^{230} \mathrm{Th},{ }^{228} \mathrm{Th},{ }^{231} \mathrm{~Pa} \text {, } \\
{ }^{227} \mathrm{Ac},{ }^{125},{ }^{229}\end{array}$ & 20 & 500 \\
\hline Th-nat, ${ }^{232} \mathrm{Th},{ }^{90} \mathrm{Sr},{ }^{223} \mathrm{Ra},{ }^{224} \mathrm{Ra},{ }^{232} \mathrm{U},{ }^{126} \mathrm{I},{ }^{131} \mathrm{I},{ }^{133} \mathrm{I}$ & 200 & 1,000 \\
\hline $\begin{array}{l}\text { Beta-gamma emitters (nuclides with decay } \\
\text { modes other that alpha emission or spontaneous } \\
\text { fission) except }{ }^{90} \mathrm{Sr} \text { and others noted above. } \\
\text { Includes mixed fission products containing }{ }^{90} \mathrm{Sr} \text {. }\end{array}$ & $\begin{array}{c}1,000 \\
\text { beta/gamma }\end{array}$ & $\begin{array}{c}5,000 \\
\text { beta/gamma }\end{array}$ \\
\hline
\end{tabular}

Notes:

1 The values in this table apply to radioactive contamination deposited on, but not incorporated into, the interior of the contaminated item. Where contamination by both alpha- and beta/gamma-emitting nuclides exists, the limits established for the alpha- and beta/gamma-emitting nuclides apply independently.

${ }^{2}$ The amount of removable radioactive material per $100 \mathrm{~cm}^{2}$ of surface area should be determined by swiping the area with dry filter or soft absorbent paper, while applying moderate pressure, and then assessing the amount of radioactive material on the swipe with an appropriate instrument of known efficiency. For objects with a surface area less than $100 \mathrm{~cm}^{2}$, the entire surface should be swiped, and the activity per unit area should be based on the actual surface area. Except for transuranic elements, ${ }^{228} \mathrm{Ra}$, ${ }^{227} \mathrm{Ac},{ }^{228} \mathrm{Th},{ }^{230} \mathrm{Th},{ }^{231} \mathrm{~Pa}$, and alpha emitters, it is not necessary to use swiping techniques to measure removable contamination levels if direct scan surveys indicate that the total residual contamination levels are below the values for removable contamination.

${ }^{3}$ The levels may be averaged over $1 \mathrm{~m}^{2}$ provided the maximum activity in any area of $100 \mathrm{~cm}^{2}$ is less than three times the values in the table.

${ }^{4}$ More restrictive level required by 49 CFR 173.443 . All other limits are in accordance with the Hanford Site Radiological Control Manual.

\subsubsection{Canister Storage Building Documentation and Procedures}

The following documentation is assumed to be required prior to acceptance by the CSB of PWR-2 fuel assembly shipments from T Plant.

- Canister/cask manifest document: This document will record the inventory of the T Plant Canister and will state the identification numbers of the PWR-2 fuel assemblies if obtainable during transfer. It will state the contamination and radiation levels on the top of the open cask and the sealed T Plant Canister prior to fitting the cask lid.

- Release certification to allow transport/cask/canister (loaded) to leave T Plant: This certification will record that contamination and radiation levels on the outside of the cask and on the transport vehicle were acceptable for 
movement outside the building and that the units are suitable for entry into the CSB. It will state that the cask lid seal has been proven effective and that the cask is secure on the transporter.

- $\quad$ Signed acceptance certificate allowing canister/cask into CSB: Prior to movement of a PWR-2 fuel assembly shipment from T Plant a signed document is required from the CSB stating that the particular shipment can be immediately accepted at the CSB.

- Release certification to allow transport/cask/canister (empty) to leave the CSB: This certification will certify that contamination and radiation levels on the outside of the cask and on the transport vehicle are acceptable for movement outside the building. The certification will state that the cask lid seal has been proved effective and that the cask is secure on the transporter.

- SNF Technical Data Package: Technical data regarding the PWR-2 fuel assemblies as required by the disposal requirements for DOE SNF in a deep geologic repository.

\subsubsection{Unioading and Storage of T Plant Canister in Canister Storage Building}

The PWR-2 fuel will be received and unloaded in the CSB in a similar manner to the $\mathrm{K}$ Basin SNF. The transporter is driven into the CSB receipt bay and the tractor unit is detached and removed. A portion of the cask access platform is removed and the cask restraint system is released allowing the cask, with canister, to be lifted off the transporter using the CSB receiving crane. The cask is moved to the MCO service Pit where the cask lid is removed. The MCO handling machine aligns with the cask and draws the canister from the transport cask and into the MCO handling machine cask. The MCO handling machine moves to the designated storage tube. The storage tube shield plug is removed and the MCO handling machine deposits the T Plant canister into the storage tube. The storage tube shield plug is then replaced.

\subsubsection{Confirm Cask Cleanliness}

After removal and storage of the T Plant Canister, the transport cask will be surveyed, both inside and out, and cleaned if required to reduce contamination to an acceptable level. The cask will be reused when it receives a Health Physics survey certificate indicating acceptable levels of contamination.

\subsubsection{Insert New T Plant Canister Into Cask at Canister Storage Building}

New T Plant Canisters will be stored at the CSB until required. When required, new T Plant Canisters will be retrieved from storage and inserted into an empty cask in the CSB. The canister shield plug will be placed in its storage holder on the transporter. The cask lid will be refitted, and the transporter/cask/empty canister combination will be stationed at the CSB awaiting notification of the next PWR-2 fuel assembly transfer. 


\subsection{EQUIPMENT AND FACILITIES}

\subsection{T PLANT EQUIPMENT AND LAYOUT}

The following sections provide information concerning T Plant's equipment and layout.

\subsubsection{Layout of T Plant}

The T Plant complex was constructed in the mid-1940's to extract plutonium from SNF using the bismuth phosphate process. T Plant performed this function until the plant was deactivated in 1956. Since then, most of the original process equipment has been removed. T Plant was placed in service as a beta-gamma decontamination facility in 1957. The layout of the T Plant complex and canyon are shown in Figures 8-1 and 8-2, respectively.

The T Plant complex is composed of several buildings and support facilities located in the northeast corner of the 200 West Area of the Hanford Site. The main structure is the 221-T Canyon Building. The building is a reinforced-concrete canyon facility approximately $260 \mathrm{~m}$ (850 ft) long by $21 \mathrm{~m}(69 \mathrm{ft}$ ) wide by $17 \mathrm{~m}(55 \mathrm{ft})$ high. It covers an area of approximately 0.53 hectares $(1.3$ acres). The major features of the building include the canyon, three galleries (operating, pipe, and electrical), one craneway, and a "headend" facility.

The canyon area consists of 37 cells and one railroad tunnel entrance and exit. The cells are paired into $12 \mathrm{~m}$ (39 ft) wide sections arranged in a single row running the length of the building. The canyon deck is $12 \mathrm{~m}(39 \mathrm{ft})$ below the $0.9 \mathrm{~m}(3 \mathrm{ft})$ thick concrete roof. The railroad tunnel is used for transporting equipment into and out of the canyon via a $4.5 \mathrm{~m}$ (15 ft) wide by $6.7 \mathrm{~m}(22 \mathrm{ft}$ ) high tunnel doorway. The doorway is covered by a motor-driven roll-up steel door. An overhead crane with hoist capacities of 45 and 10 tons is used to transport materials to and from the canyon.

Shielding walls of $2.7 \mathrm{~m}(9 \mathrm{ft})$ thick reinforced-concrete separate the canyon cells from the electrical and pipe galleries. The operating gallery is separated from the canyon deck by a $2.1 \mathrm{~m}(7 \mathrm{ft})$ thick, reinforced-concrete wall. The canyon cells are covered by four to six $1.8 \mathrm{~m}(6 \mathrm{ft})$ thick reinforced-concrete blocks and are separated by $2.1 \mathrm{~m}$ $(7 \mathrm{ft})$ thick, reinforced-concrete walls.

The PWR-2 fuel assemblies are currently stored in a storage pool (Cell 2R) located on the north side of the canyon building. This storage pool is adjacent to the underground railroad tunnel (Cell $2 \mathrm{~L}$ ) where the PWR-2 fuel assemblies were originally unloaded. The railroad tunnel will be used to remove the assemblies from T Plant using a road transporter, as described in this section. 
Figure 8-1. T Plant Complex Overview.

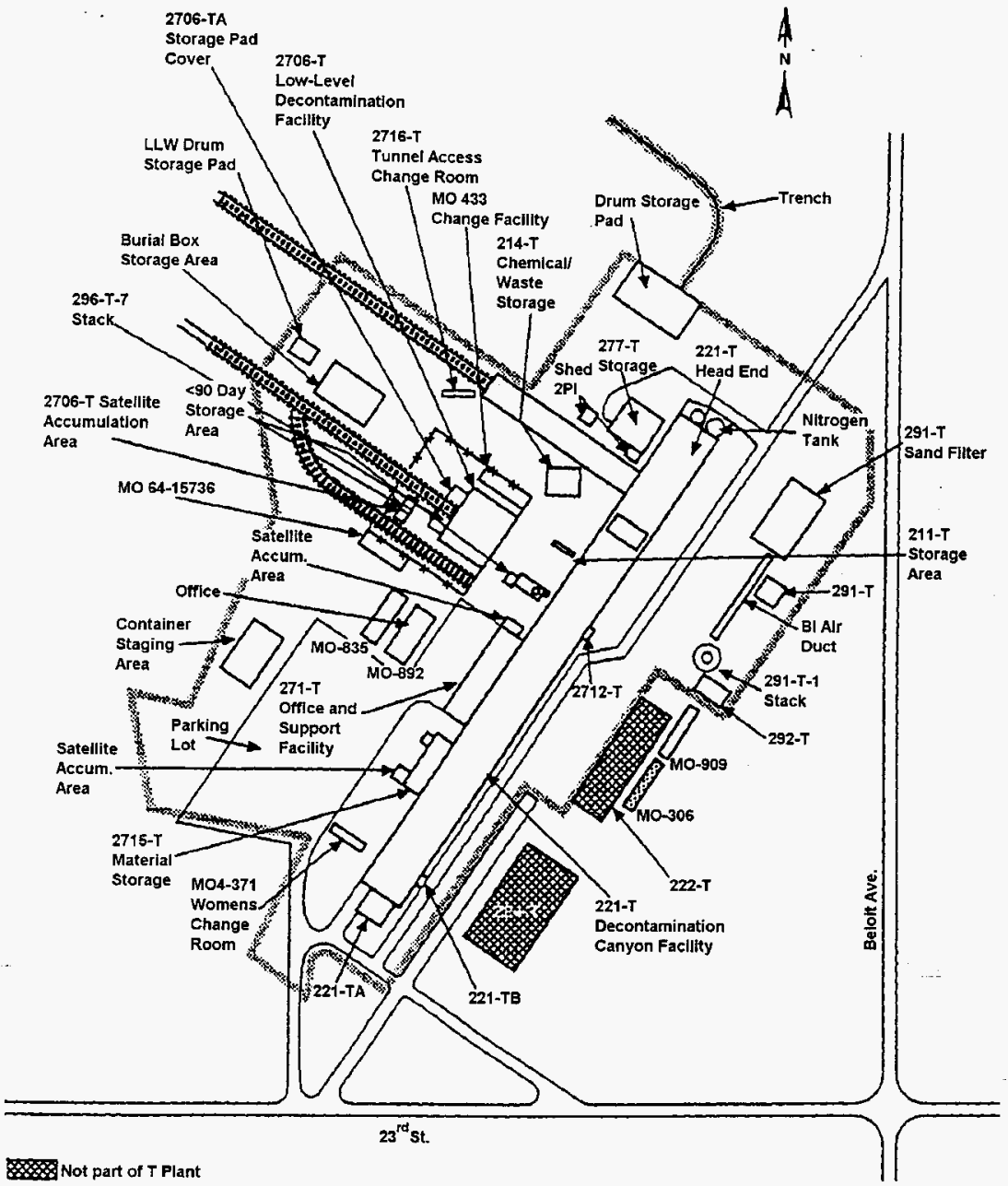


Figure 8-2. T Plant Canyon Cross Section.

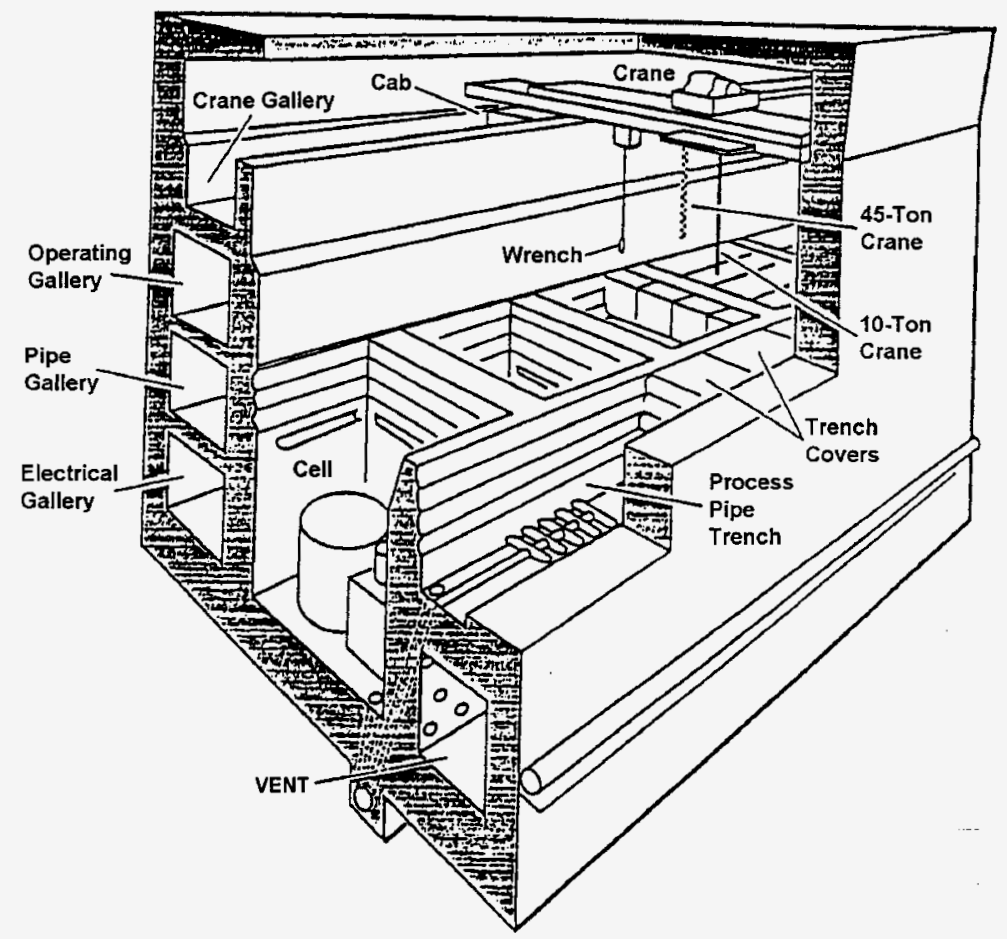


For canyon monitoring a television camera is mounted on the west wall (Canyon section 2 between railroad and PWR-2 storage cells) approximately $4.2 \mathrm{~m}(14 \mathrm{ft}$ ) above the deck. A monitor and the pan, tilt, and zoom controls for this camera are located in room 217 in the operations gallery. Room 217 also has a monitor displaying images from the crane mounted camera.

\subsubsection{PWR-2 Storage Pool and Equipment}

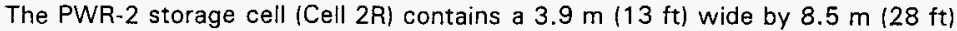
long by $8.5 \mathrm{~m}$ (28 ft) deep storage pool with a capacity of $190,000 \mathrm{~L}(50,000$ gal.) when filled to $5.8 \mathrm{~m}(19 \mathrm{ft})$. The storage pool cell was modified for the storage of the Shippingport PWR-2 fuel assemblies. A fabric liner was installed between the white concrete exterior and the existing grey reinforced concrete. A catwalk was added above the storage pool to allow access to the pool surface for sampling and equipment maintenance. Filtered, demineralized raw water was used for the initial storage pool fill and an installed demineralizer provides makeup water to replenish storage pool water lost by evaporation. An ion exchange column, installed in a radiation shield near the storage pool, was provided for removal of radioactive contamination from the storage pool water and for maintaining water quality. A historical summary of the storage pool water quality requirements are listed in Table $8-1$.

Table 8-1. T Plant Storage Pool Water Quality Limits.

\begin{tabular}{|c|c|c|}
\hline Tho e frame & Requiternents & Rivference Documents. \\
\hline $6 / 78-10 / 84$ & $\begin{array}{c}4.5<\mathrm{pH}<9.5 \\
\text { Chloride }<10 \mathrm{ppm} \\
\text { Total activity }<1 \times 10^{-2} \mu \mathrm{Ci} / \mathrm{ml}\end{array}$ & $\mathrm{RHO}-\mathrm{CD}-423$ \\
\hline $10 / 84-7 / 85$ & $\begin{array}{c}4.5<\mathrm{pH}<9.5 \\
\text { Chloride }<10 \mathrm{ppm} \\
\text { Total activity }<1 \times 10^{-2} \mu \mathrm{Ci} / \mathrm{ml}\end{array}$ & OSD-D-187-00003, Rev. 0 \\
\hline $7 / 85-2 / 91$ & $\begin{array}{c}4.5<\mathrm{pH}<9.5 \\
\text { Chloride }<10 \mathrm{ppm} \\
\text { Total activity }<1 \times 10^{-2} \mu \mathrm{Ci} / \mathrm{ml} \\
\text { Conductivity }<12 \mu \mathrm{mhos} / \mathrm{cm}\end{array}$ & OSD-D-187-00003, Rev. 1 \\
\hline $2 / 91-11 / 94$ & $\begin{array}{c}5.0 \leq \mathrm{pH}<9.0 \\
\text { Chloride } \leq 5 \mathrm{ppm} \\
\text { Total activity } \leq 1 \times 10^{-3} \mu \mathrm{Ci} / \mathrm{ml} \\
\text { Conductivity } \leq 29 \mu \mathrm{mhos} / \mathrm{cm}\end{array}$ & OSD-D-187-00008 \\
\hline $11 / 94$ - present & $\begin{array}{c}5.0 \leq \mathrm{pH}<9.0 \\
\text { Chloride } \leq 5 \mathrm{ppm} \\
\text { Total activity } \leq 1 \times 10^{-3} \mu \mathrm{Ci} / \mathrm{ml} \\
\text { Conductivity } \leq 29 \mu \mathrm{mhos} / \mathrm{cm} \\
\text { Phosphate }<2 \mathrm{ppm} \\
\text { Nitrate }<2 \mathrm{ppm} \\
\text { Fluoride }<2 \mathrm{ppm}\end{array}$ & OSD-D-187-00008 \\
\hline
\end{tabular}


The current T Plant storage pool water contaminant concentrations are listed in Table 8-2.

Table 8-2. T Plant Storage Pool Water Characteristics As Sampled on April 24, 1996.

\begin{tabular}{|c|c|c|}
\hline (1. & Reswits & Uniss \\
\hline \multicolumn{3}{|l|}{ Anions } \\
\hline Fluoride & $<0.013$ & $\mu \mathrm{g} / \mathrm{ml}$ \\
\hline Chloride & 0.848 & $\mu \mathrm{g} / \mathrm{ml}$ \\
\hline Nitrite & $<0.11$ & $\mu \mathrm{g} / \mathrm{ml}$ \\
\hline Bromide & $<0.13$ & $\mu \mathrm{g} / \mathrm{ml}$ \\
\hline Nitrate & 0.348 & $\mu \mathrm{g} / \mathrm{ml}$ \\
\hline Phosphate & $<0.12$ & $\mu \mathrm{g} / \mathrm{ml}$ \\
\hline Sulfate & $<0.14$ & $\mu \mathrm{g} / \mathrm{ml}$ \\
\hline Oxalate & $<0.105$ & $\mu \mathrm{g} / \mathrm{ml}$ \\
\hline \multicolumn{3}{|l|}{ Activity } \\
\hline Cobalt -60 & $9.79 \times 10^{-6}$ & $\mu \mathrm{Ci} / \mathrm{ml}$ \\
\hline Cesium-137 & $2.41 \times 10^{-7}$ & $\mu \mathrm{Ci} / \mathrm{ml}$ \\
\hline \multicolumn{3}{|l|}{ Other Analysis } \\
\hline Conductivity & 11.0 & $\mu \mathrm{MHOS} / \mathrm{cm}$ \\
\hline $\mathrm{pH}$ & 7.12 & $\mathrm{pH}$ \\
\hline
\end{tabular}

The 72 PWR-2 fuel assemblies are stored vertically in the storage pool in two $2.4 \mathrm{~m}$ $(8 \mathrm{ft})$ by $1.5 \mathrm{~m}(5 \mathrm{ft})$ storage racks. Approximately 50 percent of the available storage pool floor space is currently being used for storage of the fuel assemblies and each assembly is stored in a separate compartment in the rectangular metal storage racks. See Figure 8-3 for a detailed side view of a typical PWR-2 storage rack.

PWR-2 storage pool water quality is currently maintained by two separate methods, ion exchange and filtration. The ion exchange system consists of a submersible pump, a shielded ion exchange column, and stainless steel piping, valves, and instruments. The flow through the ion exchange system is regulated at $38 \mathrm{~L} / \mathrm{min}(10 \mathrm{gpm})$. The filtration system consists of a pump, two filters, and a surface skimmer. This filtration system is located on the storage pool catwalk. The piping and fittings are constructed of PVC, while the pump and filters are constructed of stainless steel. 
Figure 8-3. Typical PWR-2 Storage Rack. (Drawing H-2-72876)

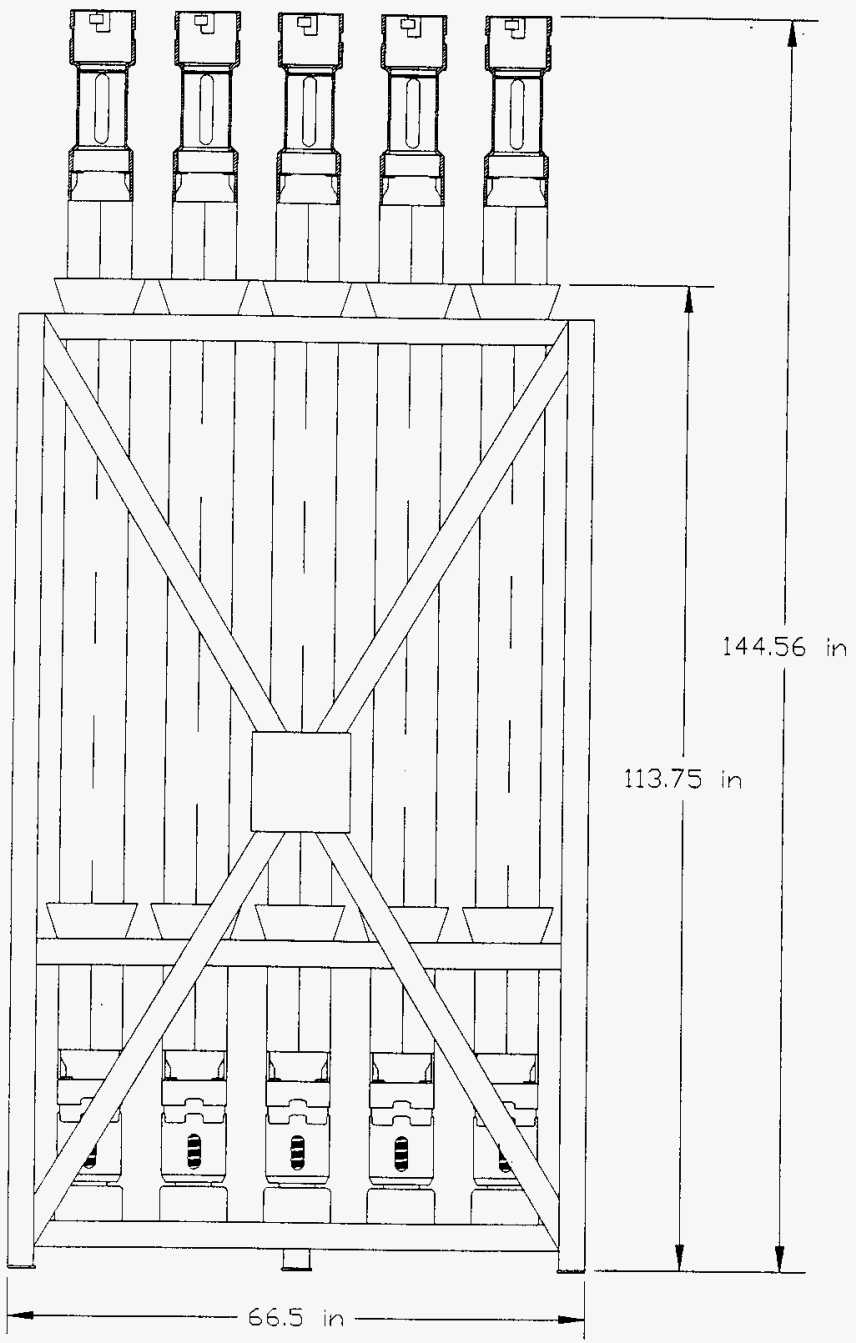


The storage pool water temperature was once controlled by the use of two sump pumps, two chillers, associated piping, and freon refrigeration equipment. The system was deactivated in 1995 after control of the water temperature was shown to be unnecessary in a 1994 test. It was shown that normal convective cooling provided sufficient water temperature control. When the system was deactivated, all equipment was left in-place. All oil and freon were drained from the refrigeration equipment after deactivation. However, design media is in-place for removal of this equipment.

An older filtration system has also been deactivated and is located on the canyon deck adjacent to the storage pool. This system also employed a submersible pump, two filters, and associated piping and fittings. The system was deactivated due to increasingly large pressure drops across the filters needed to maintain appropriate water quality. When the system was deactivated, all equipment was left in-place on the canyon deck.

\subsubsection{T Plant Cranage}

The existing T Plant bridge crane system will be used to load the PWR-2 fuel assemblies into a canister/cask prior to transport to the CSB. All lifting equipment will be designed and/or used in accordance with OSHA, 29 CFR. Details of the T Plant bridge crane are described below.

8.1.3.1 Existing 45 Ton and 10 Ton Overhead Cranes. The canyon design provides one electrical overhead bridge crane with two hoists of a design capacity of 75 and 10 tons. Both hoists operate from the same bridge and trolley. The crane moves parallel to the canyon, allowing access to the canyon deck cell area and the rail tunnel. The crane operator sits in an air conditioned cab filtered by HEPA. The crane cab is accessed via a craneway running parallel to the canyon. The crane operator operates the crane dressed in personal protective equipment. The lead shielded $(10 \mathrm{~cm}$ [4 in.] thick) crane operating cab is separated from the canyon deck by a $1.5 \mathrm{~m}(5 \mathrm{ft})$ thick concrete parapet that vertically extends $2.7 \mathrm{~m}(9 \mathrm{ft})$.

The bridge crane is an eight wheel, fixed bogie type design with an A3 drive arrangement. In 1991 the 75 ton hoist was derated to 45 tons (present capacity). The 10 ton hoist has a rotary hook for improved handling, positioning, and maneuvering functions. The crane is operated by use of a periscope and a CCTV system. The television camera is mounted on the crane bridge assembly. The periscope, located in the crane cab goes, out through the side of the cab, rises, and turns towards the canyon over the shield wall. The periscope terminates inside a tube located below the bridge crane and is setup with optic mirrors.

8.1.3.2 Existing Auxiliary Crane Equipment. The bridge crane has other remote equipment loperated from the crane cabl including left and right 1 ton capacity auxiliary hoists, an impact wrench, and an auxiliary impact wrench.

8.1.3.3 Proposed 3 Ton Auxiliary Hoist. In order to provide greater control and overall safety, this plan proposes that an auxiliary 3 ton hoist should be connected to the hook of the 10 ton bridge hoist during PWR-2 transfer operations. Given this arrangement, there will be a maximum of $1.5 \mathrm{~m}$ (5 ft) of clearance from the canyon deck for PWR-2 assembly 
transfers from the storage pool to the raiiroad tunnel. This plan anticipates that all lifting campaigns, other than lifting the cell cover blocks, will use this new auxiliary hoist. The new hoist will comply with ANSI/ASME/ B30.16, Overhead Hoists (Underhung).

The main functions of the auxiliary crane are to:

- Provide redundancy in case of bridge crane failure

- Increase reliability of lifting equipment

- Provide variable lifting speeds

- Provide reliable in-cab hook load readout

- Provide load limiting device

To achieve these functions, the auxiliary crane will be equipped with the following devices. (All controls for these devices will be located in the bridge crane cab.)

Electric Hoist. An electric hoist will be the basis of the auxiliary hoist assembly. This hoist must be capable of connecting to the existing hook of the 10 ton bridge hoist. It must be able to vertically lift a maximum of 3 tons with a hoist rope length of $12 \mathrm{~m}(40 \mathrm{ft})$. It will be a two speed winch with a lift and lower velocity of $2.1 \mathrm{~m} / \mathrm{min}$. $(7 \mathrm{ft} / \mathrm{min}$.) and $6.7 \mathrm{~m} / \mathrm{min} .122 \mathrm{ft} / \mathrm{min}$.) for both fine and coarse control.

Load Limiter. The auxiliary hoist will be equipped with a load limiter which will be connected to the 3 ton hoist motor. The load limiter will provide protection against over stressing a PWR-2 assembly during a lift by removing hoist power if the load exceeds 110 percent of the PWR-2 assembly weight $(590 \mathrm{~kg}[1,300$ pounds $])$. The existing 10 ton load limiter will be set to 3 tons.

Load Cell. The auxiliary hoist will be equipped with a load cell with a remote readout located in the crane cab. The load cell will read the weight of the load on the auxiliary crane with an accuracy of \pm 25 pounds within the range of 0 to $2,700 \mathrm{~kg}[6,000 \mathrm{lb}]$.

Hoist Interfaces. The auxiliary hoist will connect to the existing 10 ton bridge hoist with its rotating hook. The controls for all functions, and readouts of the electric hoist and its ancillary equipment will be compatible with existing controls and readouts in the bridge crane cab. All electrical requirements will interface with the existing electrical system in the T Plant canyon.

\subsubsection{Grapplers}

The following section identifies the various grapplers required to retrieve and contain the PWR-2 fuel assemblies during fuel transfer operations. The canister and cask grapplers are assumed to be identical in design to those proposed for K Basin SNF retrievai. General design parameters are given in the following subsections for all grapplers.

8.1.4.1 T Plant PWR-2 Assembly Primary Grappler. The function of the PWR-2 assembly primary grappler is to enable the transfer crane to move the PWR-2 fuel assemblies from the T Plant storage pool and place the assemblies into an T Plant Canister located in a transport cask in the railroad tunnel. This lifting process will be repeated four times per T Plant Canister fill. 
The primary grappler functional requirements needed to accomplish this function are defined in the following.

Enable PWR-2 Assembly Transfer. The primary grappler will facilitate the transfer of individual PWR-2 fuel assemblies from the T Plant storage pool to the awaiting T Plant Canister in the adjacent railroad tunnel. The primary grappler will allow the transfer crane to connect to an individual PWR-2 assembly, lift it completely out of the storage pool, allow the PWR-2 assembly to drain, transfer the assembly from the storage pool to the awaiting T Plant Canister, lower the PWR-2 assembly into the canister, and allow the crane to disconnect from the assembly and return to the storage pool for the next PWR-2 assembly.

Connect and Disconnect to and from PWR-2 Top Extension. The primary grappler will be capable of manually and remotely connecting and remotely disconnecting from the top extension of the PWR-2 fuel assemblies within the storage pool and within the T Plant Canister, respectively. Details of the manually operated primary grappler originally used to transfer the assemblies into the T Plant storage pool in 1978 and 1979 can be found on drawings $\mathrm{H}-2-71233$ and $\mathrm{H}-2-71234$. For details of the grappler connection on the PWR-2 assembly top extension, see drawing $\mathrm{H}-2-72447$ or $911 \mathrm{~F} 888$. The primary grappler will need to function underwater and in the intense radiation fields of the PWR-2 fuel assemblies throughout the entire transfer process (72 PWR-2 transfers). Indicators will also be installed to indicate when the locking pins are fully extended and retracted.

Connect and Disconnect to and from 3 Ton Auxiliary Hoist. The primary grappler will be capable of being remotely connected and disconnected from the 3 ton auxiliary hoist to facilitate grappler changes.

Structural Requirements. The primary grappler will be capable of structurally withstanding a weight of $1,140 \mathrm{~kg}(2,500 \mathrm{lb})$ during the transfer of the PWR-2 fuel assemblies from the storage pool to the T Plant Canister. The grappler will be designed, tested, and certified per Below-the-Hook Lifting Devices (ANSI/ASME B30.20).

8.1.4.2 T Plant PWR-2 Assembly Secondary Grappler. The function of the PWR-2 assembly secondary grappler is to act as an auxiliary grappler in case of primary grappler failure during transport. It will allow the crane operator to safely return the PWR-2 assembly to the storage pool (or T Plant Canister) after the primary grappler has completely failed and can no longer hold the assembly.

The secondary grappler functional requirements needed to accomplish this function are the same as the primary grappler functions described previously. Details of the manually operated secondary grappler originally used to transfer the PWR-2 fuel assemblies into the T Plant storage pool in 1978 and 1979 can be found on drawings $\mathrm{H}-2-72963$ and H-2-74620. In addition, the secondary grappler will not interfere with the operation of the primary grappler.

8.1.4.3 Fuel Assembly Grappler Holder. Grappler holders for the primary and secondary fuel assembly grapplers will need to be designed and built for storage of the grapplers when not in use. These grappler holders will need to hold each grappler firmly and in a 
vertical position so that the transfer crane hoist can remotely connect and disconnect from the grapplers. It is envisioned that the holders will be installed on the canyon deck in an accessible area for the transfer crane.

8.1.4.4 Canister Shield Plug Grappler. The function of the canister shield piug grappler is to facilitate the insertion of the shield plug into the T Plant Canister body by the transfer crane. This process will need to be repeated for each of the $18 \mathrm{~T}$ Plant Canisters.

The canister shield plug grappler functional requirements needed to accomplish this function are defined in the following.

Enable Shield Plug Manipulation. The canister shield plug grappler will facilitate the remote insertion of the shielding plug into the T Plant canister after PWR-2 transfer operations have been completed.

Remotely Connecting and Disconnecting to and from the canister Shield Plug. The canister shield plug grappler will be attached prior to commencing PWR-2 fuel assembly transfer from the storage pool. The plug will remain attached until the shield plug is either welded or bolted to the T Plant Canister body. Currently, this grappler is envisioned to be an "eye" bolt manually screwed into either canister shield plug design.

Remotely Connecting and Disconnecting to and from the Transfer Hoist. The canister shield plug grappler will be capable of being remotely connected and disconnected from the auxiliary transfer hoist suspended from the 10 ton bridge crane hoist. This is necessary because of the high radiation fields, as described in Section 6.4.

Structural Requirements. The canister shield plug grappler will be capable of structurally withstanding a weight of $1,360 \mathrm{~kg}(3,000 \mathrm{lb})$. The grappler will be designed, tested, and certified per Below-the-Hook Lifting Devices (ANSI/ASME B30.20).

8.1.4.5 Cask Lid Grappler. The cask lid will not require speciai grapplers for its handling. The lid will be equipped with four "eye" bolts. They will be used to manually attach standard shackles and slings for lifting and maneuvering the cask lid. All cask lid operations will be performed manually.

\subsection{T PLANT CANISTER}

Removal, drying, transport, and storage of the PWR-2 fuel assemblies will require the use of a containment, shielding, and transportation system. It is assumed in this plan that T Plant fuel transfers will utilize the same cask, and road transport system currently being designed for the retrieval of $\mathrm{K}$ Basin SNF. It is also proposed that $\mathrm{T}$ Plant fuel transfers will utilize, if possible and economic, the same design for $T$ Plant canister to that proposed for the $\mathrm{K}$ Basin $\mathrm{MCO}$ as the design requirements are very similar. Both are to contain SNF and both are to be designed for insertion in the CSB storage tubes. This review concluded that except for minor design changes to the MCO interior, discussed in Section 8.2.3, the T Plant canister and $K$ Basin MCO are likely to be identical. The following subsection has been extracted from the $K$ Basin functional and design specifications and is directly applicable (subject to the minor modifications detailed in 
Section 8.2.3) to the $T$ Plant canister. (Note: The $K$ basin MCO design has not yet been finalized and any modifications after this plan date must be reviewed for applicability to T Plant requirements.)

\subsubsection{K Basin Multiple Canister Overpack}

The K Basin MCO will be a single use SNF container, capable of maintaining SNF containment after having been closed and sealed. The MCO consists of a canister body, a shield plug, plug filter, draw tube, and incidental equipment. The MCO will be a cylindrical vessel that provides access to its storage cavity through the top. The MCO will be sealed using a shield plug (and fastener ring for the bolted MCO design). The MCO shield plug will be cylindrical and designed to mate with the open end of the MCO shell. It will provide shielding to allow workers access to the top of the MCO. The emission of gamma rays and neutrons through the sides and bottom of the MCO will be limited by the shielding features of the cask, MCO handling machine, CSB operating deck (while in the CSB storage tube), or process cell. The shield piug also provides penetrations, ports, and connections to allow conditioning of the contained SNF.

There are two MCO designs currently being considered for movement of K Basin SNF. The first is the welded shield plug design, which was designed by Parsons Engineering. The second is the bolted shield plug design, which is currently being designed by WHC and ICF Kaiser Hanford. Both will be designed to hold K Basin SNF in up to five internal baskets. The internal and external dimensions are the same for both designs. However, the design of the shielding plug and how the plug connects to the MCO canister body is very different, as discussed in the following section. Prototypes of both designs will be built and evaluated prior to a final design determination.

Table 8-3 and Figures 8-4 and 8-5 show the construction information and overall dimensions, respectively, of the two current MCO designs for K Basin SNF.

Table 8-3. K Basin MCO Design Details.

\begin{tabular}{|l|l|}
\hline Length & $\begin{array}{l}406 \mathrm{~cm}(160 \mathrm{in.})(360 \mathrm{~cm}[1413 / 4 \mathrm{in.}] \\
\text { minimum storage length) }\end{array}$ \\
\hline Inner Diameter & $58 \mathrm{~cm}(23 \mathrm{in.})$ \\
\hline Wall Thickness & $1.3 \mathrm{~cm}(0.5 \mathrm{in.})$ \\
\hline Construction Material & $\begin{array}{l}304,304 \mathrm{~L}, \text { and } 316 \text { Stainless Steel (The } \\
\text { shielding plug for the bolted design is } \\
\text { carbon steel }\end{array}$ \\
\hline MCO Total Empty Weight (Including Plug) & $1250 \mathrm{~kg} \mathrm{(2750 \textrm {lb } . )}$ \\
\hline
\end{tabular}

Welded MCO Design. For the K Basin welded shield plug MCO design, the shield plug would be inserted into the MCO canister body and welded to the canister body. The welded shield plug would be installed prior to leaving $K$ Basins but could be welded either at the $K$ Basin loading pit or at the cold-vacuum drying facility. 
Figure 8-4. K Basin Welded Shielding Plug MCO Design.

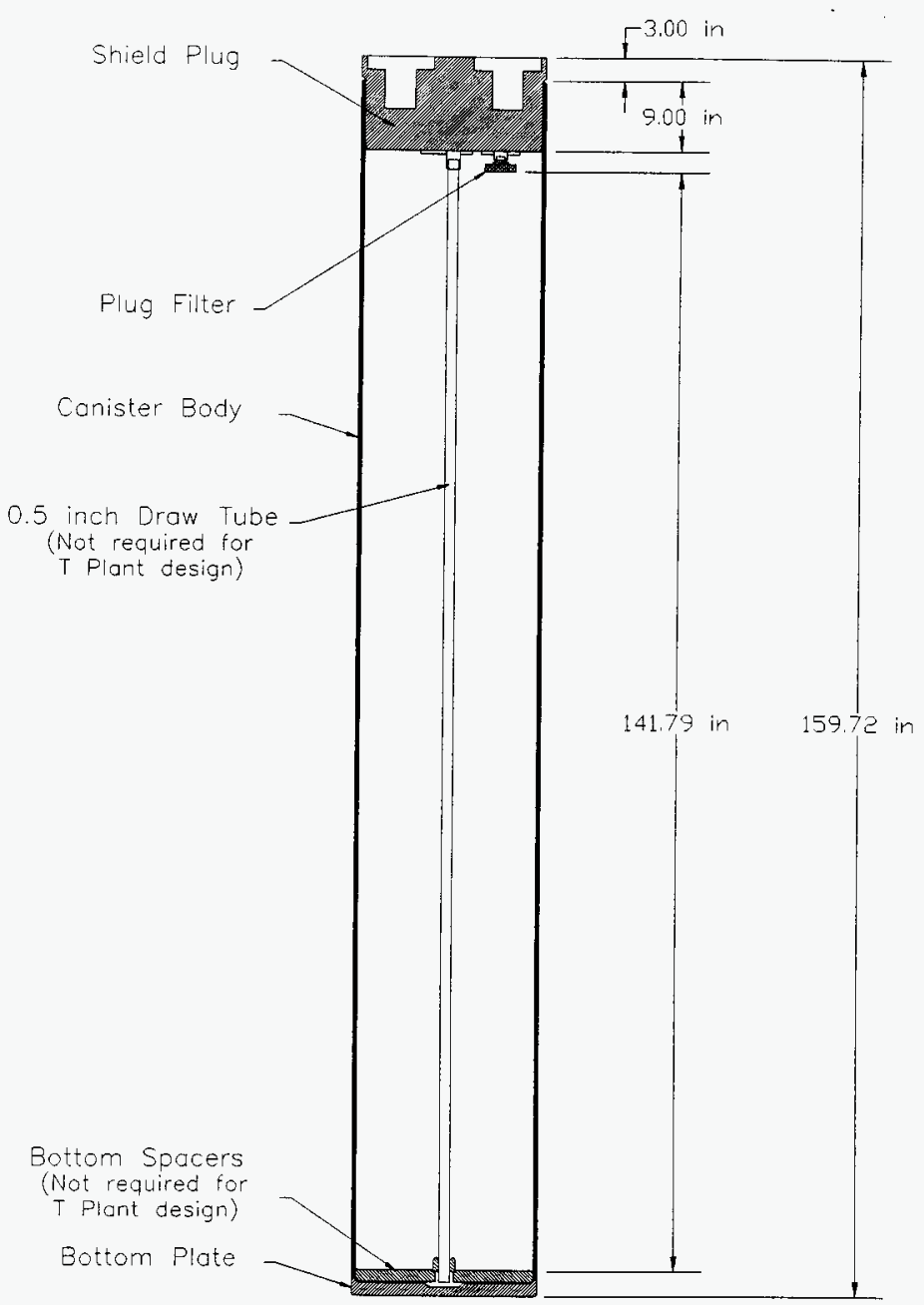


Figure 8-5. K Basin Bolted Shielding Plug MCO Design.

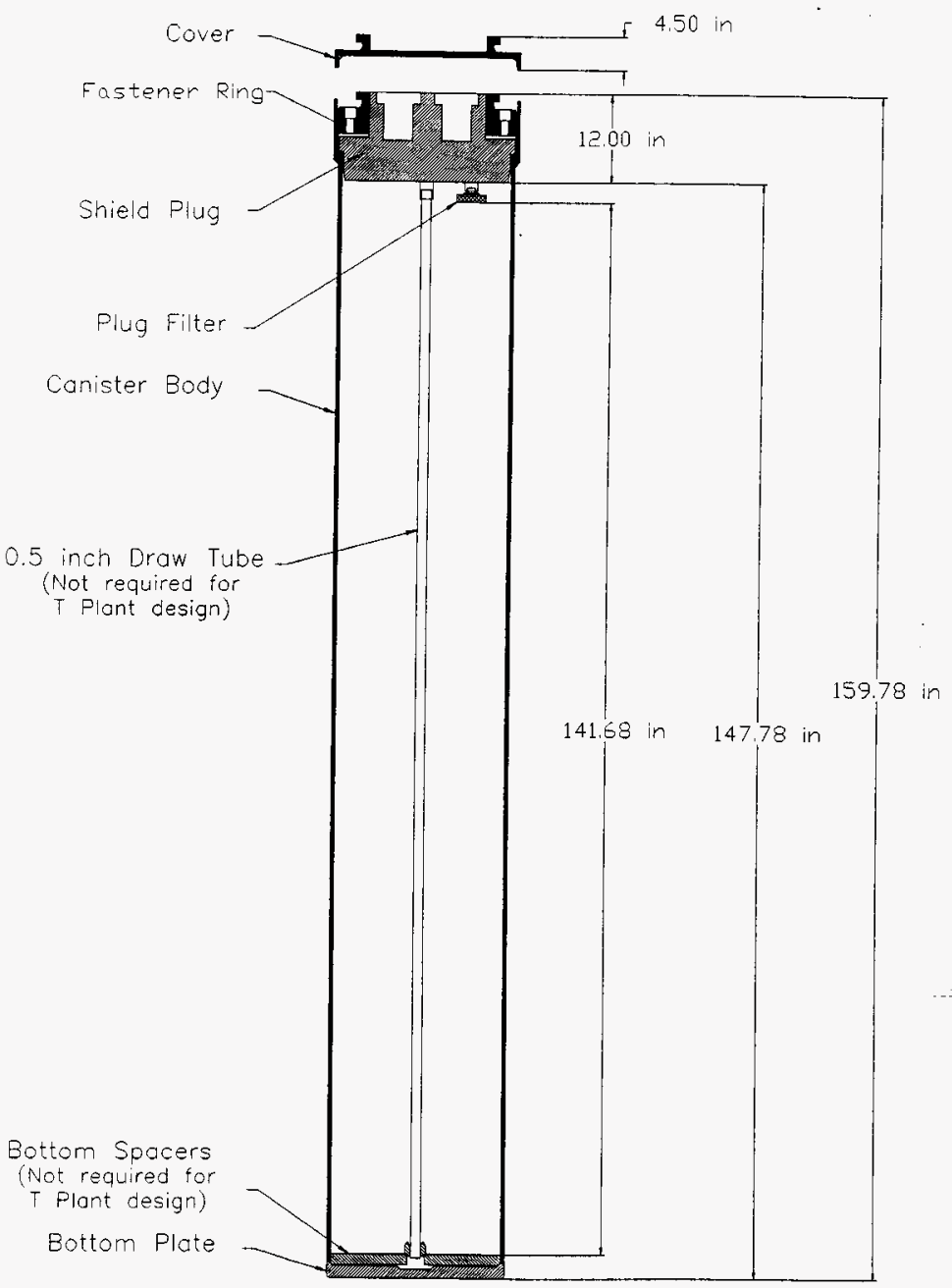


Bolted MCO Design. For the K Basin bolted shield plug MCO design, the shield plug would be inserted into the MCO canister body and held in place by a fastener ring on top of the plug. A metallic $\mathrm{O}$-ring seals the shield plug to the canister body. Following insertion of the fastener ring, the bolts would be vertically inserted through the fastener ring, applying downward pressure on the shield plug and assuring a secure O-ring seal. The assembly of the bolted shielding plug and fastener ring would take place at the K Basin loading pit. After vacuum drying and eventual hot conditioning of the SNF within the MCOs, a final MCO cover would be welded over the shielding plug, completely sealing the contents of the MCO for permanent storage. Hot conditioning and welding of the final MCO cover would take place at the CSB.

While outside the CSB, the MCO will be stored in a specially designed shielding cask for all SNF operations to protect workers during SNF transfer, transport, and vacuum drying. Inside the CSB, the MCOs will be stored in underground vertical storage tubes with two MCOs stored in each tube.

Further information on K Basin's MCO design parameters is contained in the Performance Specification for the Spent Nuclear Fuel Multiple Canister Overpack, (Goldmann 1996). In addition, Figure 8-6 provides a detail examination of the differences between the welded and bolted MCO shield plug designs.

\subsubsection{T Plant Canister}

The function of the T Plant Canister is to confine and contain PWR-2 fuel assemblies and facilitate their safe transfer from T Plant to the CSB. The canister is to serve as the processing vessel during vacuum drying of the PWR assemblies and as the containment vessel for interim storage in the CSB. As stated, except for minor design changes to the interior, the T Plant canister will be the same design as the presently designed $\mathrm{K}$ Basin $\mathrm{MCO}$. The following functional requirements, based on $\mathrm{K}$ Basin $\mathrm{MCO}$ requirements, are applicable to the $T$ Plant canister.

8.2.2.1 Interfaces. The T Plant Canister would interface with the following systems.

PWR-2 Fuel Assemblies. Four PWR-2 fuel assemblies will be placed in each T Plant Canister. Information on the PWR-2 fuel assemblies is found in Section 6.

Cask and Transportation System. The cask contains the T Plant Canister (empty) during transport from the CSB to T Plant, during canister fueling operations, and the canister (filled) during the return trip back to the CSB facility. The cask provides secondary containment and maintains acceptable leak rates during all T Plant Canister (filled) transport operations except when inside the CSB. The cask provides primary shielding for the canister contents. During and after accident conditions, the cask maintains confinement and shielding of the loaded canister.

T Plant Equipment and Systems. T Plant systems (e.g., bridge crane, electrical, process air, etc.) will be used to handle the canister shield plug and incidental equipment within the T Plant canyon and railroad tunnel. They will also be used to transfer PWR-2 fuel assemblies into the T Plant Canister, handle equipment needed to seal the canister, and facilitate the vacuum drying and inerting of the PWR-2 fuel assemblies. 
Figure 8-6. Welded and Bolted Canister Design Differences

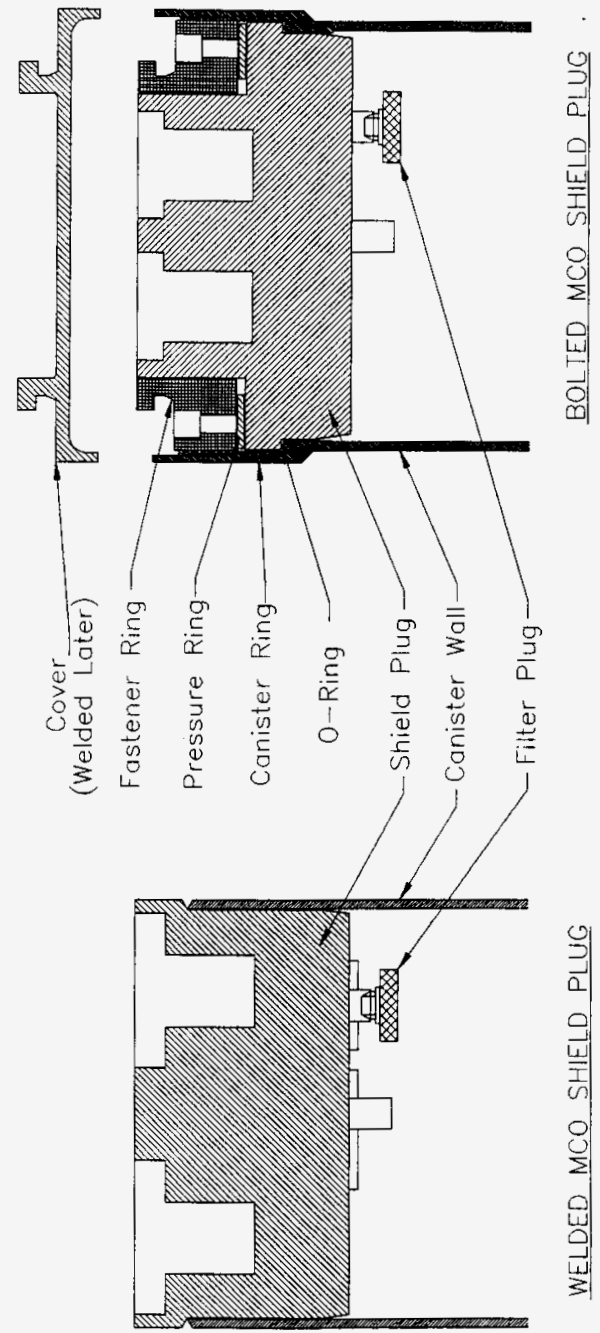


Vacuum Drying and Inerting Module. The vacuum drying and inerting equipment will use the T Plant Canister as a processing vessel and will use the canister shield plug connections to dry and place in an inert atmosphere the PWR-2 fuel assemblies. The characteristics of the vacuum drying and inerting module planned for use with $K$ Basin SNF is documented in the Performance Specification for the $K$ Basin Vacuum Drying Module (WHC 1995b). A similar document will be required for T Plant equipment.

CSB Equipment and Systems. The CSB system will receive, handle, and transfer the T Plant Canister within the CSB. The CSB will transfer the package (PWR-2 fuel assemblies, canister, and cask) off the transporter at the CSB receiving area and transfer the loaded canister from the cask using an $\mathrm{MCO} /$ canister handling machine. It will also handle the canister during transfer and retrieval from the storage tubes. The CSB systems will handle and load a new empty T Plant Canister into the cask and move the combination onto the transporter for shipment to $T$ Plant. The transportation cask containing an empty or filled T Plant canister is lifted at the CSB with the 60-ton capacity receiving crane.

8.2.2.2 Functional Requirements. The following functional requirements are based on $K$ Basin MCO functional requirements modified to pertain to the T Plant Canister. The development of $T$ Plant functional requirements would continue during detailed design of the T Plant canister.

Re-Rack PWR-2 Fuel Assemblies. The T Plant Canister will be equipped with a vertical spacer basket to hold the four PWR-2 fuel assemblies in a vertical orientation. The canister spacer basket will be capable of sustaining the weight of four PWR-2 fuel assemblies and will accommodate any anticipated bowing of the PWR-2 fuel assemblies as discussed in Section 6.6.2.

PWR-2 Confinement. The fully assembled T Plant Canister will retain within its cavity the four PWR-2 fuel assemblies. Confinement of the PWR-2 fuel assemblies is required during operations to remove the canister and fuel assemblies from T Plant and during storage at the CSB. The canister will confine the PWR-2 fuel assemblies during and after being subject to the design basis accident (DBA) scenarios.

PWR-2 Containment. The sealed T Plant Canister will maintain a maximum total leak rate (all leak paths) of $1 \times 10^{-7} \mathrm{scc} / \mathrm{sec}$ during operations to remove the PWR-2 fuel assemblies from T Plant, transfer of the fuel assemblies, and during interim storage of the fuel assemblies at the CSB. During vacuum drying and inerting, the maximum total leak rate (all leak paths, including process connections) will be $1 \times 10^{-4} \mathrm{scc} / \mathrm{sec}$. The canister will maintain the specified maximum leak rates during and after being subjected to the DBA scenarios. The allowable leak rates will be confirmed during detail design.

Enable Fuel Drying. The T Plant Canister will allow the vacuum drying of the PWR-2 fuel assemblies. This will be accomplished by providing the processing boundary, penetrations, and connections to allow the circulation of gases and vapors within the internal cavity of the canister. During vacuum drying, the canister will retain any loose materials (e.g., crud) with size greater than $2 \mathrm{~mm}(0.079 \mathrm{in.}$.). Any device (e.g., course screen) used for this purpose will be internal to the canister. 
Inerting and Purging. The T Plant Canister will allow the inerting and purging of the canister interior cavity in preparation for transport or interim storage. The T Plant Canister will allow these functions by providing penetrations and connections to allow interaction with its internal cavity prior to start of the vacuum drying process and upon arrival at the CSB. During inerting, and purging, the canister will retain within the processing boundary loose material with size greater than $2 \mathrm{~mm}(0.079 \mathrm{in.})$ to protect external equipment.

Shield Workers Against Radiation. The canister shield plug will shield workers against gamma rays and neutrons emanating from the inside of the T Plant Canister.

Recommended radiation dose limits will include radiation streaming between the canister shield plug and the canister shell and streaming around penetrations. Further details of the functional requirements for shielding will be determined after the completion of new radiation dose rate calculations recommended in Section 3.3.

Enable Handling. The T Plant Canister will enable handling of its individual components, as well as the fully assembled and loaded (four PWR-2 fuel assemblies) canister. The canister will enable its handling by providing the design features and equipment needed to interface with T Plant and the CSB facilities. The T Plant Canister handling features and equipment will be capable of holding the full weight of the package (canister, cask, and four PWR-2 fuel assemblies).

\subsubsection{T Plant Canister/K Basin Multi-Canister Overpack Design Variations}

Three modifications to the K Basin MCO design are required to facilitate the insertion and storage of PWR-2 fuel assemblies. These modifications are the removal of the bottom vertical spacers and draw tube, and the addition of a vertical spacer basket in the MCO, which would allow the insertion of four PWR-2 fuel assemblies per canister.

The bottom spacers and draw tube are included in the current MCO design to elevate the K Basin SNF baskets above the canister bottom, facilitate the removal of trapped liquids, and allow the even dispersion of injected materials (inerting and/or drying gases) through the draw tube. Since the T Plant PWR-2 fuel assemblies are believed to be intact (no degradation of the PWR-2 cladding) and the bottom extension bracket (See Figure 6-4) is already equipped with drain notches, the bottom spacers are not required. The removal (or non-installation) of the bottom spacers would increase the total vertical clearance allowed within the canister by approximately $4.44 \mathrm{~cm}(1.75 \mathrm{in}$.$) . The draw tube$ is not required as the PWR-2 fuel assemblies will be placed in a dry T Plant canister and any water carried over with the assemblies will be removed by the vacuum drying process.

To facilitate the proper insertion and adequate spacing of four PWR-2 fuel assemblies within each modified T Plant Canister, the construction and installation of a vertical spacer basket will need to be accomplished. This spacer basket is envisioned to be $1 / 4$ inch stainless steel vertical plates, "butt" welded at $90^{\circ}$ to each other. The spacer plates would extend from the bottom of the canister to within $36 \mathrm{~cm}(14 \mathrm{in.}$ ) of the shielding plug bottom. Figure 8.7 illustrates how the PWR-2 fuel assemblies and spacer basket will need to be horizontally and vertically arranged within the canister. 
Figure 8-7. PWR-2 Assembly and Spacer Basket Arrangement Within a T Plant Canister.

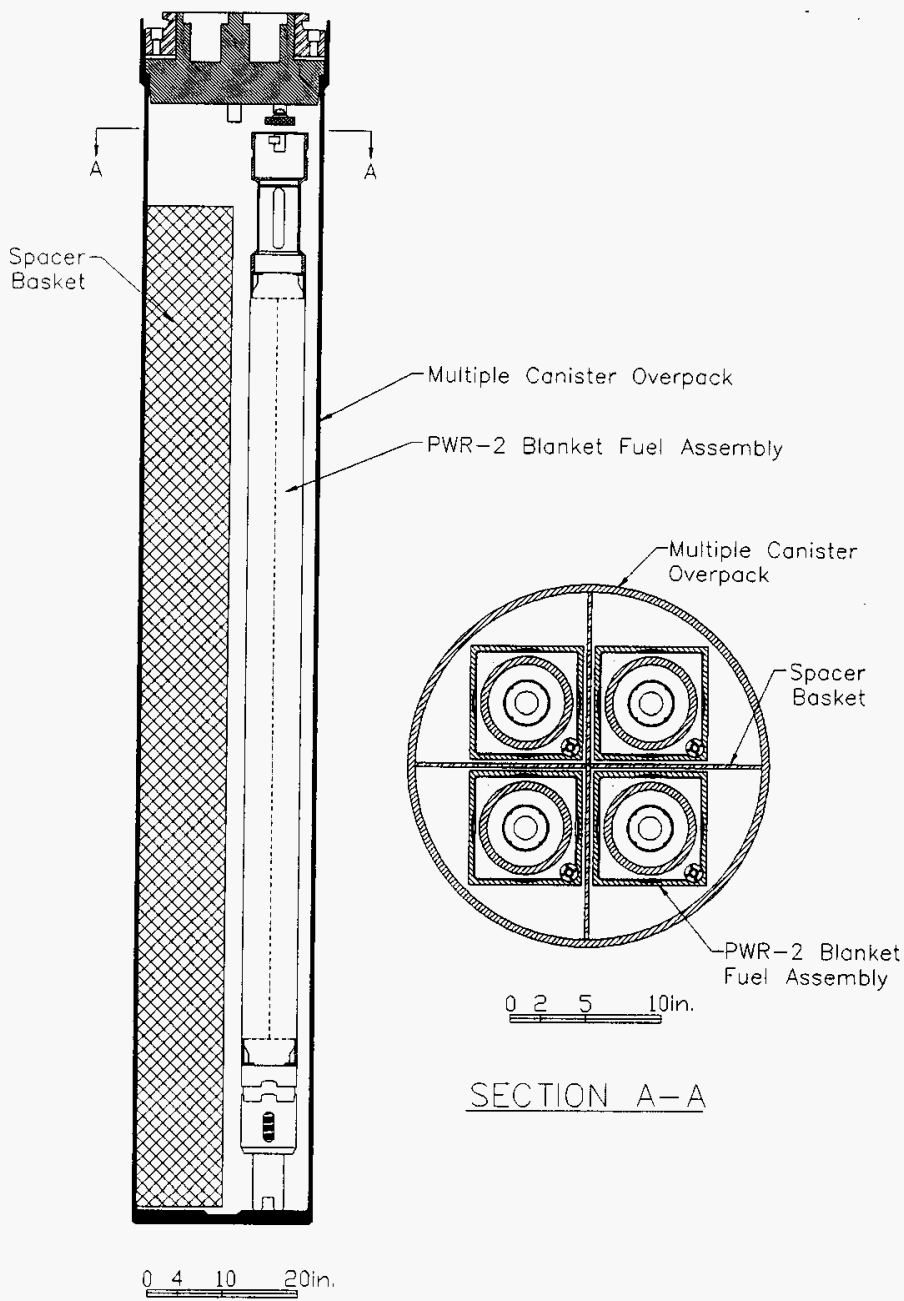


As can be seen in Figure 8-8, with the insertion of the spacer baskets and four PWR-2 fuel assemblies within the modified MCO design, the total clearance between any one assembly and the canister wall is $2.10 \mathrm{~cm}(0.826 \mathrm{in}$.).

\subsection{VACUUM DRYING EQUIPMENT}

The vacuum drying equipment will dry the PWR-2 fuel assemblies in compliance with CSB acceptance requirements. The assemblies will be dried after being placed within the T Plant Canister but before being removed from the T Plant railroad tunnel.

\subsubsection{System Interfaces}

The vacuum drying equipment will interface with the following.

Canister Shield Plug Penetrations. The vacuum drying system will have the necessary hose connections to attach to the quick disconnects on the canister shield plug. The vacuum drying system will also be equipped to handle any radioactive material that the internal shield plug filter allows to pass. It will be capable of filtering and directing this material to a controlled containment system.

T Plant Electrical System. The vacuum drying system will interface with the existing $T$ Plant electrical system. This interface will be for a power feed only. The vacuum drying skid will contain all the necessary instrumentation, switches, circuit breakers, motor starters, etc., that the system requires.

T Plant Storage Pool. The vacuum drying system will interface with storage pool. The water pump (if necessary) and vacuum pump will have discharge capabilities that will allow the condensate to be transferred to the storage pool. The vacuum pump will also be capable of discharging to the canyon ventilation system.

T Plant Equipment Layout. The vacuum drying equipment will not interfere with existing equipment or equipment proposed for use in this document. It will be capable of being placed in the rear of the rail tunnel at T Plant.

Inert Gas Source. The vacuum drying system will include the necessary manifolds to control the backfill of the T Plant Canister with inert gas. The vacuum drying system will interface with the chosen inert gas.

\subsubsection{Functional Requirements}

The vacuum drying equipment will fulfill the drying and inerting functional requirements for the T Plant Canister to satisfy CSB acceptance criteria. The following are a brief description of anticipated PWR-2 requirements extracted from Spent Nuclear Fuel Conditioning Product Criteria (WHC 1996c). Detailed definitive requirements will be produced when CSB acceptance criteria for PWR-2 fuel are issued. 
Figure 8-8. PWR-2 Fuel Assembly/T Plant Canister Clearance

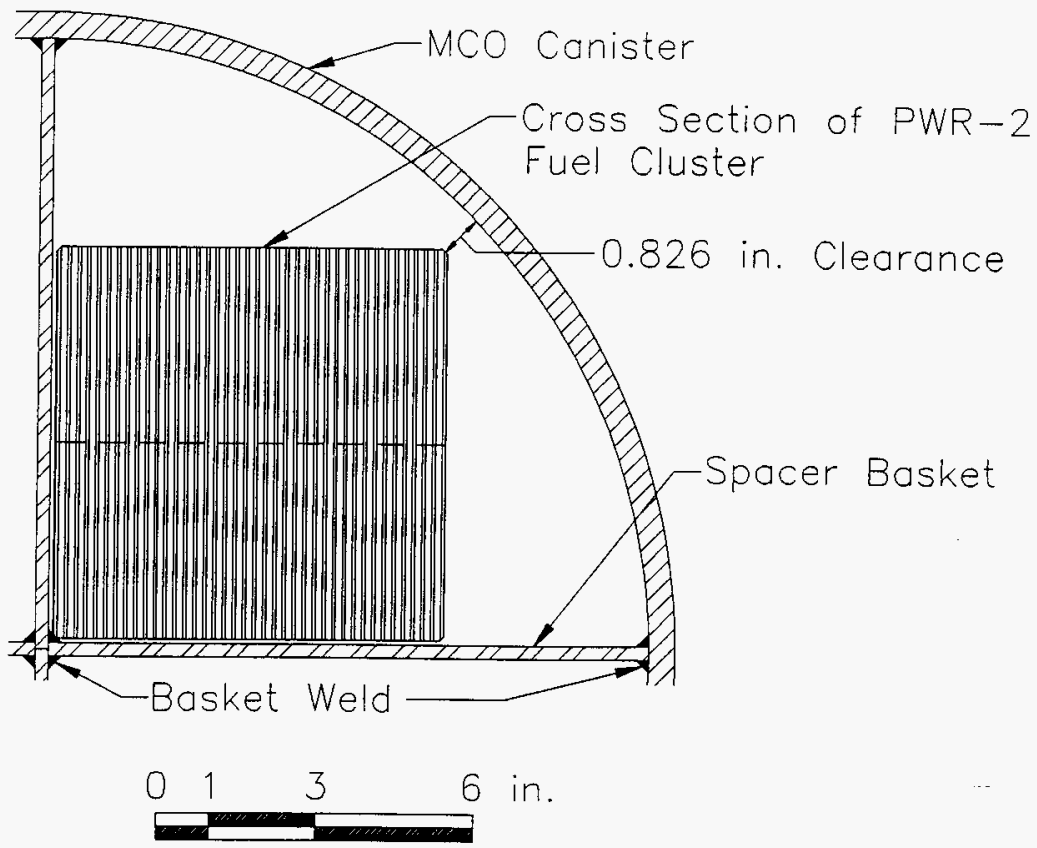


Free Gas. The T Plant Canister will not, upon sealing, contain free gas other than inert fill gas such as helium or argon, air residuals, water vapor, and radiolysis decomposition products. The inert fill gas will be initially less than $150 \mathrm{kPa}(1.5 \mathrm{~atm})$ at $50^{\circ} \mathrm{C}\left(122^{\circ} \mathrm{F}\right)$.

Oxygen Content. The amount of oxygen in the T Plant Canister will be less than 5 volume percent of the gases contained in the gaseous phase to prevent hydrogen deflagration. The vacuum drying system will be required to measure oxygen content within the $T$ Plant Canister to determine when the described limit has been reached.

Water Content. The T Plant Canister will contain no free liquid. This will be defined by holding a vacuum of 3 torr or less for a period of at least one hour.

Other Materials. No halogenated oils or oils with a low vapor pressure at conditioning temperatures will be used during vacuum drying or within the vacuum drying system.

\subsubsection{Physical Characteristics}

The vacuum drying system will incorporate the necessary equipment to accomplish the functions mentioned previously.

Vacuum Pumps. The vacuum drying skid will contain one or more vacuum pumps to pump down the T Plant Canister to the above conditions in a controlled manner so as to prevent freezing. The pump(s) will be capable of pumping air, water vapor, and the inert gas.

Other Equipment. The vacuum drying skid will contain the necessary valves, connectors, pipe and hoses to perform and interface according to the requirements stated above. The equipment will perform in a moist environment and be rated for vacuum service. The equipment will also perform as required in Sections 8.3 after being exposed to high radiation fields.

\subsection{CANISTER TRANSPORT CASK}

The transport/shielding casks used for T Plant Canisters will be the same casks used for K Basin SNF retrieval. The transport cask system will be approved for use within the boundaries of the Hanford Site and will be capable of carrying one canister. The design of the cask system ensures that the canister is capable of being loaded with four PWR-2 fuel assemblies and sealed after placement in the inner cavity of the cask. Figure 8-9 shows a K Basin transport cask loaded with a T Plant Canister. The following is a summary of cask functional requirements extrapolated from the Specification for SNF Path Forward Cask and Transportation System, (Kee 1995), which was produced for the K Basin SNF retrieval project. These requirements are included in the plan for background information only. 
Figure 8-9. Canister Transport Cask.

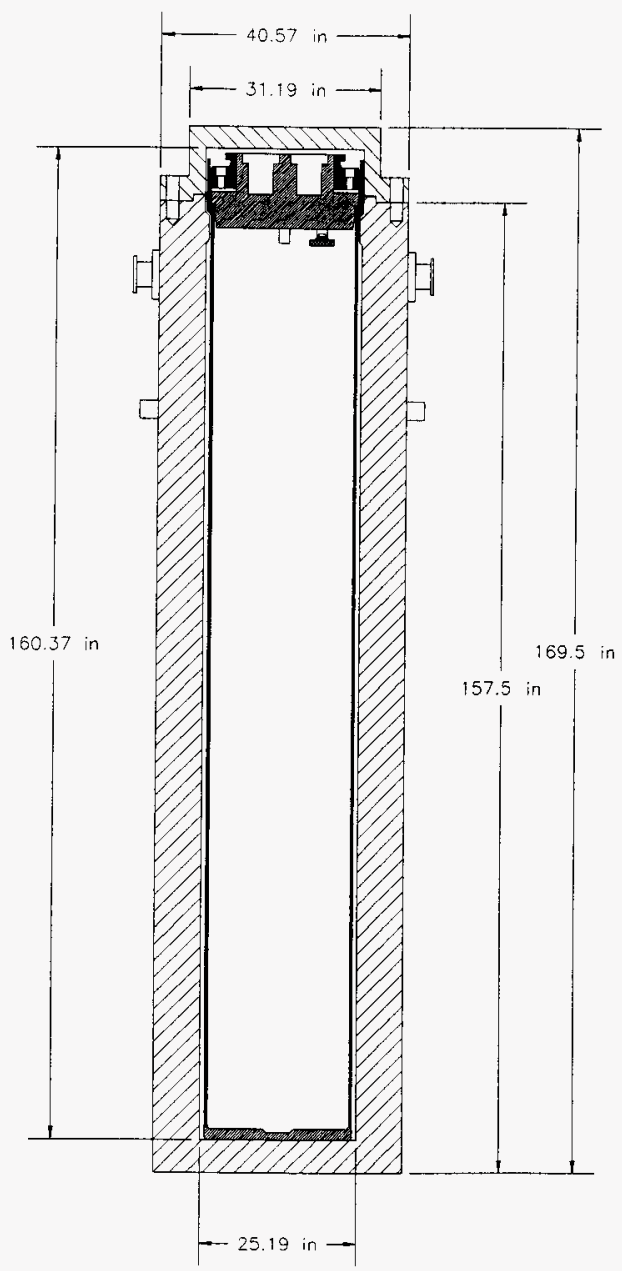




\subsubsection{Functional Requirements}

All containment boundary penetrations will be leakage rate testable. Closures will be secured with positive fastening devices that cannot be opened unintentionally. Additionally, the outermost containment boundary must incorporate tamper indicating devices (TIDs).

\subsubsection{Physical Characteristics}

Dimensions. The dimensions for the internal cavity of the cask will be sufficient to accommodate the T Plant Canister. Exterior dimensions will accommodate all the interfaces of the cask package system.

Maximum Gross Weight. Maximum gross weight of the cask system will be 25 tons.

Draining. The cask will be outfitted with a drain port and high point vent that will permit removal of liquids from the cask cavity with or without a fully loaded T Plant Canister loaded into the cask. The drain port and high point vent will be capable of being opened and closed using remote handling equipment.

Reuse. The transport cask will be capable of being reused a minimum of 20 times for transfer of PWR-2 fuel assemblies. (This is in addition to its use for K Basin SNF.)

Water Circulation. The cask will be equipped with a circulation system, capable of circulating a minimum of $76 \mathrm{~L} / \mathrm{min}(20 \mathrm{gpm}), 50^{\circ} \mathrm{C}\left(122^{\circ} \mathrm{F}\right)$ water through the cask/canister annulus. This feature will provide a uniform water temperature flow around the canister during $\mathrm{K}$ Basin SNF cold vacuum drying. The cask will have double shut-off quick release interfaces to the iniet and outlet ports on the cask. The design will include features that will retain the canister in the cask for all normal and off-normal pressures in the annulus.

It is not anticipated that the cask water circulation system will be used for vacuum drying of PWR-2 fuel assemblies since there is no evidence of fuel cladding failure. Heating of the cask exterior does not increase the final fuel dryness, but decreases the required drying time. If the vacuum drying of PWR-2 fuel assemblies needs to be expedited, a water heating and recirculating system will need to be designed and installed within the T Plant railroad tunnel.

\subsubsection{Containment (Normal Conditions)}

The cask will demonstrate containment to a leak tightness of $1 \times 10^{-7} \mathrm{scc} / \mathrm{sec}$ air. This will be demonstrated with the cask vent sealed. 


\subsubsection{Shielding (Normal Conditions)}

DOE guidelines for the design of transport casks for on-site transfers of SNF directs the use of 10 CFR 71.47 as criteria for radiation levels unless it is technically or economically infeasible to do so. The CFR states that the surface radiation levels on the outside of the cask should not exceed $200 \mathrm{mrem} / \mathrm{hr}$. The dose rate $2 \mathrm{~m}(6.6 \mathrm{ft}) \mathrm{from}$ the edge of the cask transporter will be less than or equal to $10 \mathrm{mrem} / \mathrm{hr}$. The dose rate in any normally occupied space (e.g., drivers cab) of the transfer vehicle will be less than or equal to $2 \mathrm{mrem} / \mathrm{hr}$. The SARP (when written and approved) for the package and transportation of PWR-2 fuel will state allowable radiation levels from the cask and will state if any of the above values are exceeded or reduced.

\subsection{CASK TRANSPORTER DETAILS}

The cask transporter system will be designed to transport the cask and $\mathrm{T}$ Plant Canister to and from the CSB. It will be one of the same units used for transport of $K$ Basin SNF. The following details are a summary of the details in Specification for SNF Path Forward Cask and Transportation System, (Kee 1995), and are given here for general information.

\subsubsection{Transporter System}

The current transporter system design includes a cask work platform mounted on a $12 \mathrm{~m}$ (40 ft) double drop trailer. The transporter will also consist of a truck and trailer system, associated specialty equipment, tools for operation or maintenance, anchors for cask tie down, and any other items needed to transport the cask. This system will be used solely on the Hanford Site to transport SNF casks. The transport method will be designed to meet the applicable regulations, constraints, performance criteria, and interfaces listed and required for uses on the Hanford Site.

\subsubsection{Transporter Interfaces}

As a minimum, the cask transporter will interface with the following items.

Local Roads and Facilities. The transporter system will operate on the roads shown in Figure 7-7. It is recommended that a study of utilities located above le.g., power lines, steam lines, etc.) and below (e.g., water lines, culverts, etc.) be performed to determine if any utilities will need to be upgraded or temporarily moved due to the size and weight of the loaded transporter.

T Plant Rail Tunnel Access. The transporter will interface with the T Plant rail tunnel and access area. The access ramp to the T Plant tunnel will need to be upgraded prior to PWR-2 fuel shipments. The upgrade will include resurfacing and strengthening the access ramp to a 40 ton loading, widening the asphalt on the ramp to $3.6 \mathrm{~m}(12 \mathrm{ft})$ and installing $0.3 \mathrm{~m}(1 \mathrm{ft})$ wide by $0.6 \mathrm{~m}(2 \mathrm{ft})$ deep concrete reinforcing curbs flush with each side of the asphalt. (See Figure 8-10 and 8-11.) 
Figure 8-10. T Plant Tunnel Access Road.

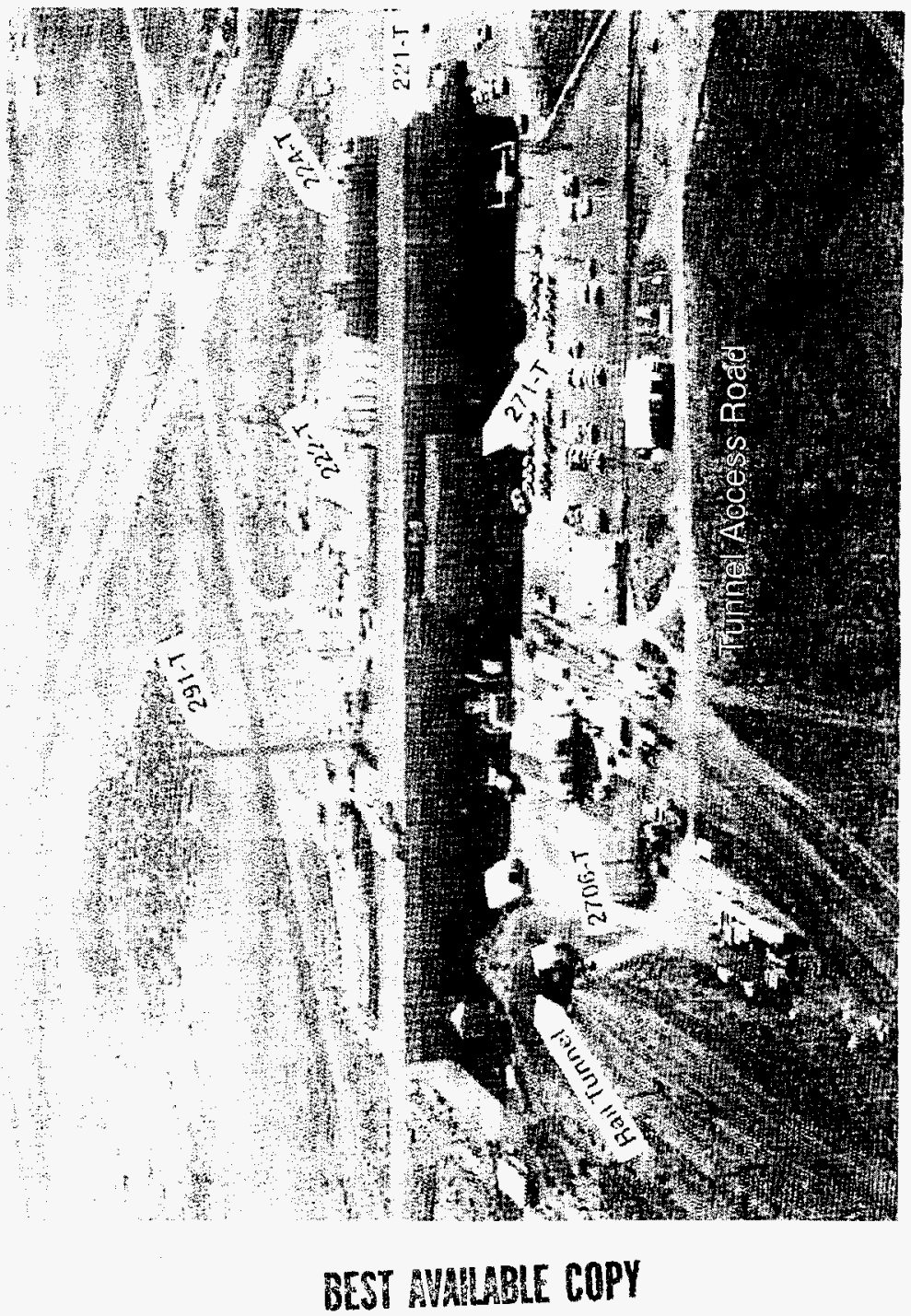


Figure 8-11. T Plant Tunnel Access Ramp Required Upgrades.

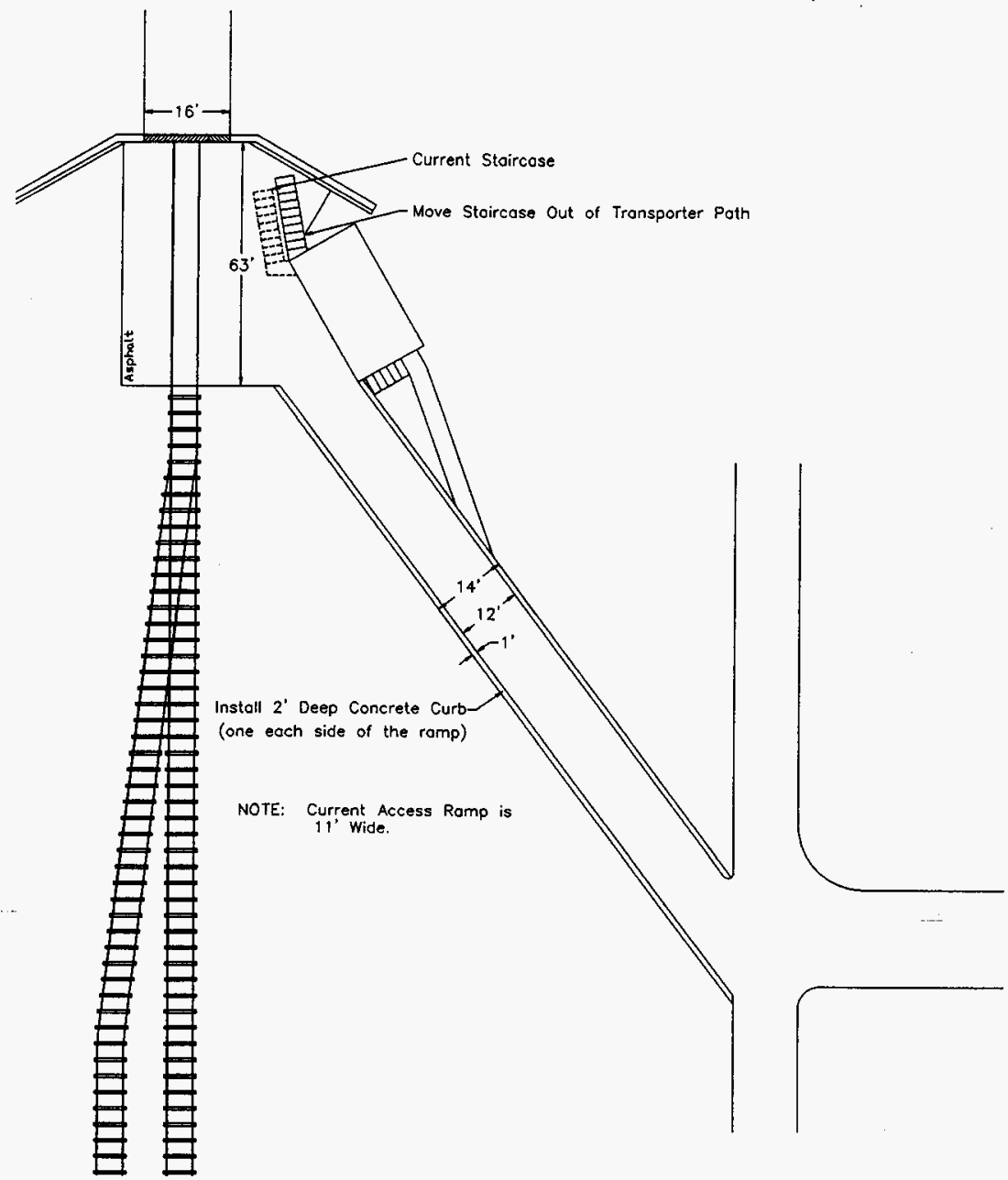


The stairs and ramps to the change room at the tunnel entrance will need to be modified. A section of the handrail for the ramp on the north side of the change room will need to be removed to provide the $4.2 \mathrm{~m}$ (14 ft) wide clearance required by the wider asphalt. The stair case on the south of the change room currently extends out from the front of the change room and narrows the access path to the tunnel entrance. This stair case will have to be moved to a position similar to that shown in Figure 8-11.

There is currently an unimproved road that closely parallels the northwest security fence at $T$ Plant and connects with the T Plant parking lot (see Figure 8-10). This is the road that the transporter will use after leaving the tunnel. This will need to be upgraded to an asphalted road $4.2 \mathrm{~m}(14 \mathrm{ft})$ wide and rated for 40 tons, the standard loading for Hanford Site roads.

Tractor. The transporter system will be compatible with a Hanford Fleet tractor. The anticipated tractor will be model 2T6 of the Ford L-Series. The transporter, with cask system installed, will be capable of being detached from the tractor.

Cask. The transporter system will easily accept the cask during loading and unloading using existing overhead cranes and equipment at T Plant and CSB facilities. A means of securing the cask to the transporter will be provided.

\subsubsection{Functional Requirements}

The following outline the required functional requirements that the cask transporter will be required to comply.

Weight. The transporter system will be able to be transported on the Hanford Site for operation upon the routes and weight limits shown in Section 7.3.

Maneuverability. The transporter system, with or without the cask system, will be able to negotiate the proposed route at speeds not in excess of $64 \mathrm{~km} / \mathrm{h}(40 \mathrm{mph})$.

Landing Gear (Trailer System). The landing gear will incorporate pads capable of accommodating a fully loaded conveyance system on soil or pavement. Allowable soil bearing pressure is $95.7 \mathrm{kPa}\left(2000 \mathrm{lb} / \mathrm{ft}^{2}\right)$.

The landing gear will be either hydraulic or a two speed, manual crank, both with sand pads capable of accommodating a fully loaded transporter.

Ancillary Equipment. Any ancillary equipment required for the cask and conveyance systems (e.g., toolbox, tools, cask, canister shield plug, spare tires, etc.) will have a means to be attach and stored on the conveyance system.

Decontamination Requirements. The conveyance system design will provide for decontamination of all exposed surfaces. There will be no blind or hidden corners or joints in areas potentially exposed to contamination that cannot be readily accessed from the top side by hand held spray devices. Any deck joints will be covered or seal welded and where applicable, will be ground flush. Any use of deck sheeting will allow for expansion and contraction so that thermal will not cause deck buckling. 
Dimensional Requirements. The length of the trailer for the conveyance will be no longer than $12.1 \mathrm{~m}(40 \mathrm{ft})$. The width of the tractor/trailer combination, with cask system, will not exceed $3.0 \mathrm{~m}(10 \mathrm{ft})$. The height with the cask system attached in a vertical configuration will allow access to the $T$ Plant railroad tunnel and the CSB. Height of the

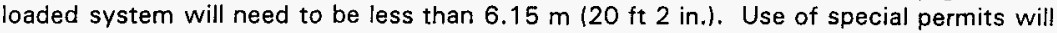
allow exceptions to Hanford highway height and width requirements.

Structural Tiedown Anchors. An engineered tiedown system will be used to secure the packaging system to the conveyance. The tiedown system will meet the requirements and be designed per the International Atomic Energy Agency Safety - Series 37. The tiedown attachments for those systems are noted as follows (Table 8-4).

Table 8-4. Design Forces for Cask Transporter Tiedown Attachments.

\begin{tabular}{|c|c|c|c|}
\hline Transport & Songitudinaly & Lateral & Yerical \\
\hline Road & $\pm 2 \mathrm{~g}$ & $\pm 1 \mathrm{~g}$ & $3 \mathrm{~g}$ down, $2 \mathrm{~g}$ up \\
\hline
\end{tabular}

\subsection{CANISTER STORAGE BUILDING}

This plan assumes that the CSB is the designated interim storage facility for the PWR-2 fuel assemblies currently stored at T Plant. This facility is currently under construction as an interim storage location for SNF at $\mathrm{K}$ Basins. The design basis of the facility is based on the containment, condition, and radiation level requirements of $K$ Basin SNF.

This plan also assumes that the PWR-2 fuel assemblies generally fall within the $K$ Basin design baseline and that the current CSB design basis will not need to be modified. However as stated in Section 6 the T Plant fuel contains ${ }^{60} \mathrm{Co}$ and ${ }^{244} \mathrm{Cm}$ which fall outside the bounds of the $\mathrm{K}$ Basin inventory. The effects of these on worker dose will need to be determined following the new dose calculations recommended in Section 3.3.

Since the same K Basin transport and shielding cask and road transporter will be used for T Plant PWR-2 fuel assembly transfers as that used for K Basin SNF transfers, no size or handling conflicts will occur. Similarly, since the K Basin MCO and T Plant canister have the same external dimensions, CSB handling and storage operations for the T Plant Canisters are the same as for K Basin MCOs.

Assuming four PWR-2 fuel assemblies are stored in each T Plant Canister, T Plant PWR-2 fuel assemblies will require the use of 9 of the CSB storage tubes or the capacity to store $18 \mathrm{~T}$ Plant canisters.

\subsection{DESIGN PACKAGE REQUIREMENTS}

Functional design criteria will need to be prepared to initiate Title $\mid$ and II design of all new equipment. This would include physical definition, required interfaces, and functional requirements. Detailed procedures for the preparation of functional design criteria can be found in Project Management System (DOE 1987), and General Design Criteria (DOE 1989). 


\subsection{MAINTENANCE}

All new equipment built and/or modified to facilitate the transfer of the PWR-2 fuel assemblies to the CSB will be designed to minimize maintenance and/or testing requirements. Features requiring maintenance will be designed in accordance with As Low As Reasonably Achievable (ALARA) principles. All new equipment will have maintenance manuals in appropriate detail to instruct maintenance personnel in the required periodic maintenance. Maintenance will be performed as appropriate to allow the safe and efficient use of all equipment throughout the transfer program.

\subsection{QUALITY ASSURANCE}

The following subsections outline the quality assurance guidelines that will be used during the implementation of this plan.

\subsubsection{General Requirements}

The phase one design agent will formulate and execute quality assurance programs that provide the following assurances.

- Performance requirements and design criteria are established, documented, and clearly understood.

- Studies, analyses, and design decisions are fully documented.

- Design meets performance requirements and design criteria.

- Design is complete, adequate, and properly documented.

- Traceability to the requirements of the contract technical specification is maintained.

\subsubsection{Responsibility for Quality Assurance}

The phase one design agent will be responsible to plan and document quality assurance audits, including those under the direct responsibility of lower tier subcontractors. The buyer will reserves the right to access and inspect work performed by the contractor and his subcontractors, as well as to direct additional inspections.

\subsubsection{Quality Assurance Requirements}

The project activities will generally be conducted in accordance with the requirements of Packaging and Transportation of Radioactive Materials 110 CFR 71 1994) and the SWDD QA plan 534, Section 1.9. The degree of application of the quality assurance requirements will be dependent on the importance of the equipment, process, 
and facilities to prevent or mitigate an uncontrolled release of radiological and hazardous material as defence-in-depth barriers (safety criteria). This is accomplished through the "graded approach" process which determines the appropriate level of effort necessary to attain and document the requirements established.

The purchase of the T Plant canisters and the fuel characterization and loading activities will additionally have to follow the appropriate Office of Civilian Radioactive Waste Management Quality Assurance Requirements and Description (QARD), reference RW-0333P in addition to 10 CFR 71 subpart $\mathrm{H}$. 


\subsection{SAFETY BASIS}

This section covers the safety analysis documentation required for transferring the 72 PWR-2 fuel assemblies currently stored in the T Plant storage pool to. the CSB vault. This includes the establishment of:

- Recommendations for Unreviewed Safety Questions Determinations (USOD) and safety analyses requirements.

- Safety analysis documentation required and the associated schedules and cost estimates.

The transfer operation will consist of 18 shipments, each with 4 PWR-2 fuel assemblies. Each shipment will be performed in four phases:

1. Loading empty T Plant canister into transportation cask and transferring empty canister from the CSB to T Plant (no safety significance).

2. Retrieval and transfer of the PWR-2 fuel assemblies from the storage pool in T Plant to a T Plant Canister located inside a transportation cask.

3. Transport of the fuel assemblies in the cask/canister from $\mathrm{T}$ Plant to the CSB.

4. Retrieval and transfer of the T Plant Canister from the transportation cask within the CSB to a CSB storage tube.

This section will also cover the status of the T Plant and $K$ Basin Safety Authorization Basis Documentation (SABD) and the existence of USOs for each phase of the PWR-2 transfer operation. The current SABD for T Plant and $K$ Basin relative to the PWR-2 transfer was reviewed to identify required changes to the SABD that which will need to be documented in amendment packages. The estimated cost for producing the required amendment packages is also presented. The related time schedules are included in Section 13.0.

\subsection{CURRENT STATUS OF SAFETY BASIS DOCUMENTATION}

The SABD for T Plant operations is an ISB document (WHC 1996a) and an IOSR document (WHC 1996d). The ISB document is currently under review by DOE, but for planning purposes will be assumed to be the current T Plant safety document. The SNFP SABD applicable to the PWR-2 fuel assembiy removal and storage operation is currently being developed for the CSB/K Basin SNF removal and storage operation. A SARP is being prepared for the transportation of SNF from K Basin to the CSB. A SAR is being prepared for operations at the CSB involving the K Basin SNF activities. A separate SAR is being prepared for the cold vacuum drying facility. In addition, a supporting MCO safety topical report is being prepared that covers $\mathrm{MCO}$ analyses common to all phases of the $\mathrm{CSB} / \mathrm{K}$ Basin operation. The current or planned SABD for the K Basin SNF removal and handling operations and T Plant operations are shown on Figure 9-1. Also shown is the anticipated SABD for the PWR-2 fuel assemblies removal and handling operations. 


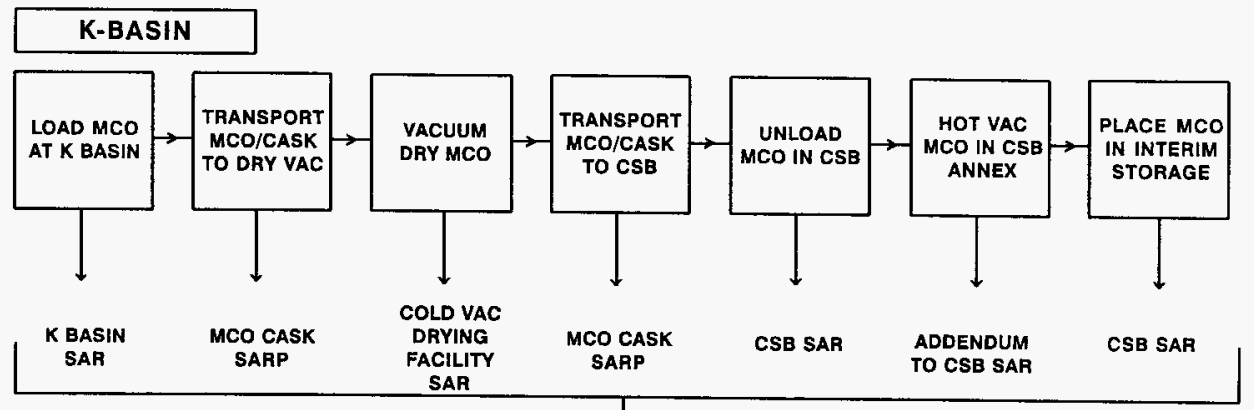

MCO TOPICAL

REPORT

T PLANT

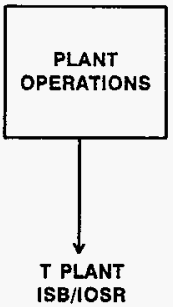

PWR 2

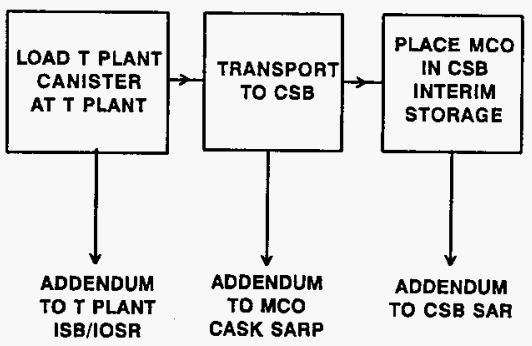




\subsubsection{T Plant Safety Authorization Basis Documentation Status}

The ISB and IOSR documents have been prepared for T Plant and have been submitted to the DOE for approval. Most of the comments from DOE have been resolved. One remaining comment concerns the control of the water level in the T Plant storage pool and the need for a related IOSR. It is expected that the ISB and IOSR documents will be approved shortly. It is therefore anticipated that the ISB and IOSR documents will have received final approval when the development of the SABD for the PWR-2 fuel assembly transfer from T Plant is started.

\subsubsection{Canister Storage Building/K Basin Safety Authorization Basis Documentation Status}

The transfer of K Basin SNF to the CSB is scheduled to begin in December 1997. The SARP being prepared for transport of materials from $K$ Basin to the CSB is underway and is expected to be approved by March 1997.

The development of the SAR for the CSB operations is also underway. The CSB SAR chapters and the Technical Safety Requirements (TSR) document have been divided into eight groups that are related to a defined phase of the SAR development program. Each group will submit their sections separately to DOE as completed and according to a schedule that ranges from March 1996 to May 1997. This May delivery is expected to be the completed version and the final submittal. Approval is expected by July 1997.

The development of the MCO Topical Report is underway and is scheduled to be submitted to DOE by September 1996. Other reports common to the total CSB/K Basin operation are Criticality Safety Evaluation Reports (CSERs). Currently, two CSERS are planned. One CSER is for the 100 Area (K Basin and CVD facilities) and the other is for the 200 Area facilitates (CSB and HCS). These are under development.

\subsection{UNREVIEWED SAFETY QUESTIONS DETERMINATION}

The Federal requirement for application of the USO process at DOE nuclear facilities is covered in Unreviewed Safety Questions (DOE 1991). The governing procedure for application of the USQ process at WHC managed nuclear facilities is covered in Standard Operating Practices, Section 7.3, Identifying and Resolving Unreviewed Safety Questions, IWHC 1995e). Guidelines more specific to T Plant are covered in Solid Waste Dispōsal Operations Administration, Section 1.24, Unreviewed Safety Questions, (WHC 1995d).

The intent of DOE Order 5480.21 (DOE 1991) is to preserve the DOE authorization basis for a nuclear facility while allowing for "operational" flexibility. The authorization basis consists of those aspects of the facility design basis and operation requirements that are considered to be important to the safety of facility operations and are relied upon by DOE to authorize operation. "Authorization basis" is considered to mean the same as "safety basis" as defined in DOE Order 5480.23 (DOE 1992b). "Safety basis" is defined as the combination of information relating to the control of hazards at a nuclear facility (including design, engineering analyses, and administrative controls) upon which DOE depends for its conclusion that activities at the facility can be conducted safely. 
The USQ process has been established by DOE to allow contractors to make physical and procedural changes and to conduct tests and experiments without prior DOE approval as long as the resulting changes do not implicitly or explicitly affect the safety basis of the facility or result in a change to a TSR/IOSR. The USO process also ensures that discoveries representing conditions outside the safety basis or TSRs/IOSRs are identified and appropriate actions taken.

\subsubsection{T Plant Unreviewed Safety Question Determination}

In order for the USQ process to function, there must be a DOE approved safety authorization basis in place. At T Plant, the safety documentation that will soon provide the authorization basis for DOE approval is the T Plant ISB document (WHC 1996a) and the T Plant Interim Operations Requirements document (WHC 1996d). Review of the T Plant ISB revealed that it does not cover the proposed PWR-2 transfer activities. The T Plant ISB states the following:

"Safety issues associated with moving cell $2 \mathrm{R}$ cover blocks or removing the PWR Core assemblies from their present location are not within the scope of this ISB and would need to be analyzed prior to initiating those activities."

USQ evaluation of the activities to retrieve and transfer the PWR-2 fuel assemblies in T Plant will substantiate that a USQ exists. Thus, to comply with DOE Order 5480.21 (DOE 1991), it is recommended that the formal USO process be initiated and followed. The time required to perform the screening and evaluation should be minimal. The time consuming part of the USQ process will be the development of an amendment to the T Plant ISB, generally in the form of an Engineering Charge Notice (ECN) that presents the required safety analyses.

\subsubsection{CSB and Transportation/Packaging Unreviewed Safety Question Determination}

The safety basis documentation covering the mission for transporting SNF from $K$ Basins and storing it in the CSB will consist of a SARP, a CSB SAR, a SAR for the facility to cold vacuum dry the $\mathrm{K}$ Basin $\mathrm{MCO}$, and a supporting topical report on the MCO. The operations to be performed and the related safety documents to be developed are shown in Figure 9-1. The DOE authorization to perform this mission will have to be received by the SNFs organization prior to December 1997 in order to meet current schedules. Depending on the date that the development of safety documentation for the PWR-2 fuel assembly transport to and storage in the CSB starts, there may or may not be an approved authorization basis for the $\mathrm{K}$ Basin activities/operations described above. If development starts prior to approval of the authorization basis, then the formal USO process cannot be followed. However, if the CSB safety basis documentation is sufficiently developed, the USO process can be informally started with the assumption that little significant change to the content of the safety basis will occur when approved in final form. Based on current schedules, it is anticipated that the SABD for the K Basin SNF operations will indeed either be complete or in an advanced state of development when the PWR-2 safety documentation is started. Therefore, it is expected that the USO process can be implemented, either formally or informally and that required changes can be included in the final K Basin/CSB authorization basis. 

is made:

In a draft of the CSB SAR annotated outline (WHC 1996e), the following statement

"The initial CSB FSAR will not at this stage address the possible future functions of unused CSB vaults.... Any modifications to the scope of operations within the CSB facility will be incorporated in future SAR revisions..."

From this statement and discussions with the SARP development organization, it is apparent that a USO evaluation of transporting PWR-2 fuel assemblies and storing them in the CSB will substantiate that a USO exists for both of these phases. Thus, to comply with DOE Order 5480.21 (DOE 1991), it is recommended that the formal USO process be initiated and followed assuming that authorization basis for both the CSB and transportation phases have been approved and that the USO personnel have been assigned and trained to perform the USO functions. If the authorization basis has not been approved and start of the SABD for the PWR-2 fuel assemblies is desired, it is recommended that the USQ process be informally started. In either case, the USOD will be a formality requiring minimal time since it is apparent that a USQ in these two phases of the T Plant PWR-2 operation will exist.

\subsection{SAFETY ANALYSIS}

The application of the USO process to the T Plant SABD and the CSB/MCO cask $S A B D$ will lead to the development of SABD amendment packages that will contain the necessary safety analysis to obtain DOE authorization to transfer the PWR-2 fuel assemblies from T Plant to the CSB. The definition of safety analysis for the USO process is defined as follows in DOE Order 5480.23 (DOE 1992b).

"Safety analysis is a documented process to systematically identify the hazards of a DOE operation; to describe and analyze the adequacy of the measures taken to eliminate, control, or mitigate identified hazards; and to analyze and evaluate potential accidents and their associated risks."

\subsubsection{T Plant Safety Analyses}

The safety analyses amendment package required to show that the PWR-2 fuel assembly retrieval within $T$ Plant is safe should be documented in an addendum to the current T Plant ISB, generally in the form of an ECN. This analysis should cover (only to the extent needed) those areas of the ISB for which additional or modified information is required.

The areas of the T Plant ISB where significant changes or additions will likely be required are shown on Table 9-1. The first column of this table lists the major sections of the ISB. For each section there are columns that show whether the need for a change is likely and a short notation characterizing the change/addition required. 
Table 9-1. T Plant ISB Addendum Evaluation Sheet, PWR-2 Operation. (2 sheets)

\begin{tabular}{|c|c|c|c|}
\hline 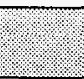 & ISB content & $\begin{array}{l}\text { Ghange } \\
\text { heqp }\end{array}$ & Modification Ghange \\
\hline 1.0 & Introduction and Summary & Yes & Prepare for PWR 2 removal. \\
\hline 1.1 & Purpose & Yes & Prepare for PWR 2 removal. \\
\hline 1.2 & Conclusions & No & \\
\hline 1.3 & SBD Upgrades & No & \\
\hline 1.4 & $\begin{array}{l}\text { Summary of Configuration } \\
\text { Management System }\end{array}$ & No & \\
\hline 2.0 & $\begin{array}{l}\text { Site, Facility and Organization } \\
\text { Description }\end{array}$ & & \\
\hline 2.1 & $\begin{array}{l}\text { Hanford Site and } 200 \text { West Area } \\
\text { Description }\end{array}$ & No & No change anticipated. \\
\hline 2.2 & $\begin{array}{l}\text { T Plant Description (also } \\
\text { Appendix A) }\end{array}$ & Yes & $\begin{array}{l}\text { Include changes due to Safety Significance SCC design requirements. } \\
\text { Describe Dry/Vac System and any components/systems unique to } \\
\text { PWR removal operation. }\end{array}$ \\
\hline 2.3 & $\begin{array}{l}\text { Process Description (also } \\
\text { Appendix B) }\end{array}$ & Yes & Include PWR removal operation description. \\
\hline 2.4 & Status of Facility Improvements & No & \\
\hline 2.5 & Organization Description & Yes & Describe organization for PWR removal with interfaces to SNFP. \\
\hline 2.6 & Nearby Facility and Activities & No & Performed as part of ISB annual update. \\
\hline 3.0 & ISB Evaluation & & \\
\hline 3.1 & Hazards Analysis (also Appendix C) & Yes & $\begin{array}{l}\text { Perform PHA for PWR removal operation. Establish PWR related } \\
\text { accidents to be analyzed. }\end{array}$ \\
\hline 3.1 .1 & $\begin{array}{l}\text { Accident Analysis and } \\
\text { Consequences (also Appendix C) }\end{array}$ & Yes & $\begin{array}{l}\text { Analyze PWR related accidents, as required. Describe codes not } \\
\text { discussed in ISB. }\end{array}$ \\
\hline 3.1 .2 & $\begin{array}{l}\text { Hazard Categorization lalso } \\
\text { Appendix B) }\end{array}$ & Yes & $\begin{array}{l}\text { Perform } 1027 \text { Hazard Categorization. Reassess } 1027 \text { Hazard } \\
\text { Categorization based on consequence and/or probability } \\
\text { considerations to justify facility hazard Category } 3 \text {. }\end{array}$ \\
\hline
\end{tabular}


Table 9-1. T Plant ISB Addendum Evaluation Sheet, PWR-2 Operation. (2 sheets)

\begin{tabular}{|c|c|c|c|}
\hline & Isplontent & Mrorge & Hodiffration/Grange. \\
\hline 3.1 .3 & Criticality Analysis & Yes & Discuss CSER results. \\
\hline 3.2 & Hazards Control & & \\
\hline 3.2 .1 & Safety SSC (also Appendix E) & Yes & Evaluate and modify, as required. \\
\hline 3.2 .2 & $\begin{array}{l}\text { Administrative Controls/Operational } \\
\text { Restrictions (also IOSR Document) }\end{array}$ & Yes & Evaluate need and add needed IOSRs for PWR removal operation. \\
\hline 4.0 & $\begin{array}{l}\text { Hanford Generic and Facility } \\
\text { Specific Controls }\end{array}$ & No & No change anticipated. \\
\hline
\end{tabular}


The manpower required for developing the T Plant amendment package is estimated to be slightly less than one man-year at an estimated cost of about $\$ 110,000$ (time schedules are presented in Section 13.0). This estimate is based on the following assumptions:

a. DOE approves T Plant classification as facility hazard Category 3 . It is anticipated that the following arguments will be substantiated and T Plant will remain a hazard Category 3 facility.

b. DOE accepts the use of qualitative analysis, as prescribed in DOE-STD-1027-92 (DOE 1992a), as being sufficient for analyzing hazard Category 3 accidents.

c. Analytical models used for K Basin SNF shielding analysis for shine (important during $\mathrm{MCO} /$ canister shield plug bolt tightening) can be readily modified for the same PWR-2 canister/cask geometry but with different basket design and inventory.

d. PWR-2 fuel assembly criticality concerns are not credible. It is anticipated that this will be substantiated by WHC. The fuel assemblies contain natural uranium irradiated in a thermal reactor. The federal regulation $10 \mathrm{CFR} 71.53$ lists such material as being exempt from fissile material classification. In addition, the 1978 CSER (Miller 1978) for the PWR-2 fuel assemblies strongly suggests that criticality occurrence is not credible.

If arguments result in the facility being classified as hazard category 2, source term reduction through the use of facility features and/or operating procedures must be taken into account. This will require these features to be classified as 'safety significant' and shown to meet specific design and operating criteria defined in WHC-CM-4-46, Section 9, Table 2. Quantitative accident analysis will need to show that the dose to onsite and offsite personnel will be acceptable. The development of IOSRs might also be required.

Of the areas requiring modification, the ones that will be most severely impacted are those associated with the analysis and control of accidents. Based on the total PWR-2 fuel assembly inventory and applying the DOE-STD-1027-92 (DOE 1992a) hazard Category 2 thresholds, the sum of the ratios calculated in the T Plant ISB (see Table 9-2) shows the facility would be a hazard Category 2 . Under the current operating conditions, however, an argument was made in the ISB that reduced the PWR-2 fuel inventory at risk to 0.05 percent of the total, resulting in a facility hazard Category 3 . However, potential accident scenarios relating to the retrieval and transfer of the PWR-2 fuel assemblies within $T$ Plant will potentially negate the current hazard category analysis by increasing the fuel assembly inventory at risk. As an example, considering only the radioisotopes in a single fuel assembly (1.34 percent of the total) to be the inventory at risk (during transfer from the storage pool to the canister), the sum of the ratios is calculated to be about 20 (see Table 9-2). Since this value exceeds the value of 1.0 , the facility would need to be reclassified as a hazard Category 2. This will present (according to DOE-STD-1027-92) the potential for significant onsite consequences. In order to reduce these consequences, facility features that can reduce the source term released will be taken into account. 


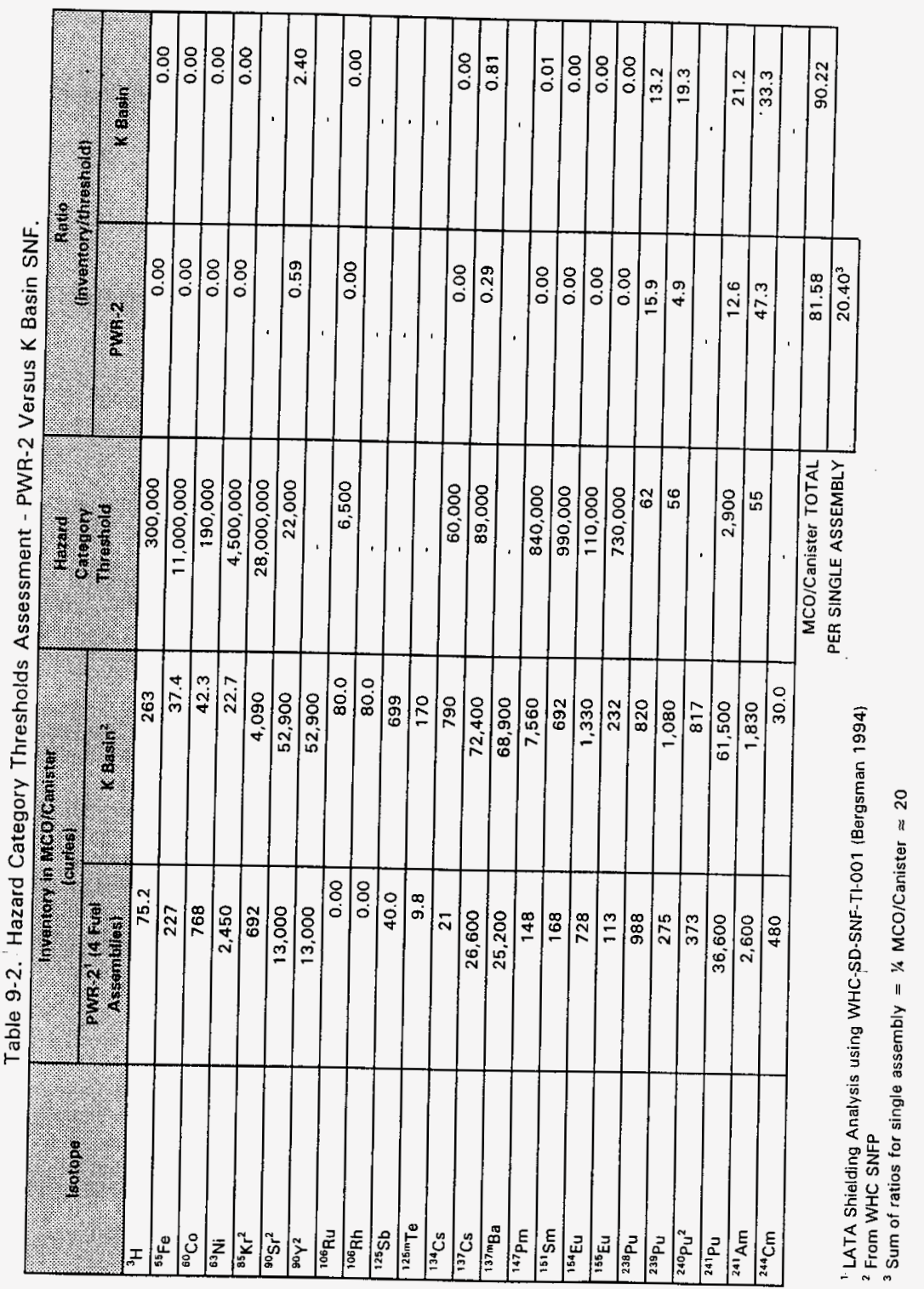


Assumptions to be developed that should keep the facility at a hazard Category 3 include:

a. Introduction of structural anaiysis to show that a PWR-2 fuel assembly drop will not effect the full length of the assembly and that not all the fuel would be involved.

b. Because of fuel cladding and the physical nature of the fuel, it can be shown that the inventory released would be less than then a fraction $\left(1.0 \times 10^{-3}\right)$ of that used in DOE-STD-1027-92 (DOE 1992a).

By applying the above assumptions, it is anticipated that a classification of $T$ Plant as a hazard Category 3 facility during the PWR-2 operation can be substantiated.

In a report on criticality prevention (Miller 1978) for PWR-2 blanket fuel assemblies, an infinite multiplication factor, $k_{\infty}$, of 0.91 for the most reactive PWR-2 blanket assemblies in a water flooded condition is reported. It also states that "a more reactive state may be postulated if the fuel is somehow separated from the cladding and module material and then arranged in a favorable configuration." Based on this statement, analyses will be required to show that no potential for criticality exists. This analysis will be reported in a CSER.

The T Plant ISB addendum will have to show that the organization specific to the PWR-2 fuel assemblies activities is in place and that interfaces with the SNFP organization have been established. Facility description will likely be minimal, addressing any changes resulting from the fuel assembly retrieval and transfer procedural requirements.

Based on the previous discussions, it is recommended that a hazards assessment be performed as early as reasonably possible to identify the potential events that could release radioactive materials and justify a facility hazard Category 3 . Because of the transient nature of the PWR-2 retrieval and transfer operation, it is recommended that the amendment package remain separate from the ISB and that no significant revision be made to the ISB. When the PWR-2 operation has been completed and required cleanup activities have been performed, the addendum can be removed from the authorization basis documentation. Changes can then be made to the ISB, which will only consist of removing text concerning the PWR-2 and updating any text concerning modifications to the facility (e.g., removal of the deionization chamber and other components associated with the PWR-2 storage pool).

\subsubsection{Transportation and Packaging Safety Analysis}

On-site transportation activities are conducted in accordance with the on-site transportation program as implemented in Hazardous Material Packaging and Shipping, WHC-CM-2-14 (WHC 1995a). The authorization basis for the program is found in DOE-RL letter 95-SWT-186. (Note - a more definitive authorization letter is in the approval cycle at DOE-RL) On-site transportation is different from off-site transportation, which is regulated by the Department of Transportation. 
On-site transportation safety practices are based on elements from the Department of Transportation (49 CFR) and NRC (10 CFR 71) regulations for off-site hazardous materials transportation; the NRC (10 CFR 72) regulations for spent fuel storage, which includes on-site movement of spent fuel; the contractor facility safety analysis program (WHC-CM-4-46); ALARA principles; and risk management. The program utilizes a risk-based development, operations, and safety analysis process graded by the hazard posed by the material being transported.

The T Plant Canister and shipping cask for the $K$ Basin SNF transport will be used for transporting the PWR-2 fuel assemblies from T Plant to the CSB. The canister internal design will be modified to accommodate four PWR-2 fuel assemblies. Once sealed, the canister exterior will be the same for both the PWR-2 loads and the K Basin loads. Some of the primary internal differences important to safety are:

1. Radiation Levels

2. Content (isotopic inventory, location, chemical form, etc.)

3. Thermal Loading

4. Internal Structure/Weight

5. Criticality Potential

Because of these differences, safety analyses unique to the transporter used for PWR-2 transfers will be required. To take advantage of the common areas of safety analysis documented in the MCO cask SARP, the best approach for documenting the safety analysis for the PWR-2 transportation phase is to prepare an addendum to the MCO cask SARP. The areas of the MCO cask SARP where significant changes or additions will likely be required are shown on Table 9-3. The first column of this table lists the major sections of the SARP. For each section there are columns that show whether the need for a change is likely and a short notation characterizing the change/addition required.

A preliminary assessment of the hazard category sum of ratios for a PWR-2 shipment versus a K Basin shipment indicates that the PWR-2 inventory would be slightly less hazardous (see Table 9-2). In addition, the PWR decay heat is expected to be less than that for a typical $K$ Basin load. The analysis performed will show that the $T$ Plant shipment falls within the safety envelope established in the MCO cask SARP.

Based on the previous discussions and because of the similarities between the PWR-2 and $K$ Basin transport loads, it is currently recommended that the safety analysis for the PWR-2 fuel assembly transport be prepared as an addendum to the MCO cask SARP. It is believed that much of the MCO cask SARP will be directly applicable to the PWR-2 transport operation. 
Table 9-3. SARP Addendum Evaluation Sheet, PWR-2 Operation. (2 sheets)

\begin{tabular}{|c|c|c|}
\hline 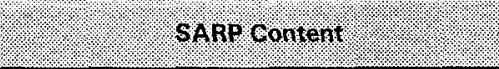 & Chargo & Modificationterange \\
\hline \multicolumn{3}{|l|}{ Part A: Description and Operations } \\
\hline Executive Summary & & Prepare for Addendum \\
\hline 1.0 Introduction & Yes & Modify: General information and System Description \\
\hline 2.0 Packaging System & Yes & $\begin{array}{l}\text { Modify, as needed, to reflect T Plant Canister changes to include: } \\
\text { Configuration \& Dimensions, Materials of construction., Mechanical } \\
\text { Properties of Materials, Weights and Center of Gravity, Contain } \\
\text { Boundary, heat Dissipation, Shielding. }\end{array}$ \\
\hline 3.0 Package Contents & Yes & $\begin{array}{l}\text { Change based on PWR content to include: General Description, } \\
\text { Content Restrictions, Radioactive Materials Description, and } \\
\text { Non-Radioactive Materials Description }\end{array}$ \\
\hline 4.0 Transport System & No & \\
\hline 5.0 Acceptance of Packaging for Use & No & \\
\hline 6.0 Operating Requirements & Yes & $\begin{array}{l}\text { Change to identify any PWR } 2 \text { transport unique General Operating } \\
\text { Requirements, Loading Requirements, Unloading Requirements, } \\
\text { Empty Package Handling }\end{array}$ \\
\hline 7.0 Quality Assurance & No & $\begin{array}{l}\text { The } K \text { Basin/CSB QA requirements should be much the same for PWR } \\
2 \text { Transport. }\end{array}$ \\
\hline 8.0 Maintenance Control & No & $\begin{array}{l}\text { The PWR maintenance requirements should be much the same as for } \\
\text { the } \mathrm{K} \text { Basin/CSB. }\end{array}$ \\
\hline 9.0 Appendix: Drawings & Yes & $\begin{array}{l}\text { Change to include those drawings and sketches unique to PWR } 2 \\
\text { transport. }\end{array}$ \\
\hline
\end{tabular}


Table 9-3. SARP Addendum Evaluation Sheet, PWR-2 Operation. (2 sheets)

\begin{tabular}{|c|c|c|c|}
\hline & saripcontint & meqriga & Modificationighange \\
\hline \multicolumn{4}{|c|}{ Part B: Package Evaluation } \\
\hline 1.0 & Introduction & Yes & Change only as needed to show evaluation results. \\
\hline 2.0 & Radiologicai Risk Evaluation & Yes & $\begin{array}{l}\text { Prepare new section for PWR to include: Characterization; } \\
\text { Restrictions; Size and Weight. }\end{array}$ \\
\hline 4.0 & Containment Evaluation & No & \\
\hline 5.0 & Shielding Evaluation & Yes & $\begin{array}{l}\text { Modify, as needed, to include: Radiation Source Specification; } \\
\text { Evaluation for Normal Transfer Conditions; Evaluation for Accident } \\
\text { Conditions. }\end{array}$ \\
\hline 6.0 & Criticality Evaluation & Yes & $\begin{array}{l}\text { Modify to reflect PWR load evaluation for: Normal Transfer } \\
\text { Conditions; Accident Conditions. }\end{array}$ \\
\hline 7.0 & Structural Evaluation & Yes & $\begin{array}{l}\text { Modify, as needed, to include: Structural Evaluation Package } \\
\text { discussion; Evaluation for Normal Conditions; Evaluation for Accident } \\
\text { Conditions. }\end{array}$ \\
\hline 8.0 & Thermal Evaluation & Yes & $\begin{array}{l}\text { Modify, as needed, to reflect PWR load to include: Thermal Source } \\
\text { Specification; Material Thermal Properties; Evaluation for Normal } \\
\text { Conditions; Evaluation for Accident Conditions. }\end{array}$ \\
\hline 9.0 & $\begin{array}{l}\text { Pressure and Gas Generation } \\
\text { Evaluation }\end{array}$ & Yes & Modify to show potential pressure and gas buildup. \\
\hline 10.0 & Package Tiedown Evaluation & No & \\
\hline
\end{tabular}

${ }^{1}$ Documentation needs will be reviewed and revised, as appropriate, when the start of the safety document is started based on the then current design and operations. 


\subsubsection{Canister Storage Building Safety Analysis}

A SAR is being prepared for the CSB K Basin operations in compliance with DOE Order 5480.23 (DOE 1992b) and according to the format and guidelines in DOE-STD-3009-93 (DOE 1993c). It is also being prepared to show compliance with the K Basin Spent Nuclear Fuel Project-Regulatory Policy (DOE 1995a), which establishes DOE's policy that new SNF project facilities will achieve nuclear safety equivalence to comparable NRC licensed facilities. To do so, the more restrictive requirements of NRC versus DOE requirements are being imposed to the extent necessary. To date, approximately $29 \mathrm{NRC}$ items have been identified that differ from DOE requirements and criteria.

Two significant items, for example, are the need to consider a tornado at Hanford and the specification of a more severe earthquake as the basis for facility design.

In addition to the CSB SAR, an MCO Topical Report is being prepared that will include analyses for the MCO that are MCO component limiting and common to all phases.

The operation in the CSB for retrieving the T Plant Canister from its cask and placing it into a tube in the CSB vault will closely follow the initial operations for retrieving a K Basin MCO from its cask and temporarily storing it in a vault tube. At present, it is believed that the T Plant Canister will not require a hot conditioning treatment. The canister will be placed directly into a CSB storage tube for interim storage. Following the USO process, the required safety analysis documentation for the PWR-2 activities/ operations in the CSB will be the development of an amendment package to the $\mathrm{CSB} / \mathrm{K}$ Basin SAR. Because the same MCO/canister vessel and transportation cask are being used, much of the CSB SAR for K Basin SNF will be applicable to PWR-2 operation. The safety analysis will likely show that $T$ Plant Canisters fall within the safety envelope for the K Basin MCO design. Since the PWR-2 fuel assemblies are designed to be stored in the CSB for 40 years, the approved amendment should be integrated into the CSB SAR for the $K$ Basin SNF during an annual SABD update. From a review of the MCO Topical Report content, it is believed that any changes required can be folded into the CSB SAR amendment package.

The areas of the CSB/K Basin SAR where significant changes or additions will likely be required are shown on Table 9-4. The first column of this table lists the major sections of each document. For each section there are columns that show whether the need for a change is likely and a short notation characterizing the change/addition required.

Assumptions include:

a. Parameters associated with the PWR-2 loaded canister fall within the envelope defined by the CSB SAR for the K Basin MCO. Based on current information, the $T$ Plant Canister decay heat and radioactive inventory biological effectiveness are expected to be similar to or less than the K Basin MCO loading. 
Table 9-4. CSB SAR Addendum Evaluation Sheet, PWR-2 Operation. (2 sheets)

\begin{tabular}{|c|c|c|}
\hline (3. & $\begin{array}{l}\text { Change } \\
\text { Regl? }\end{array}$ & Moditicationichange \\
\hline Executive Summary & Yes & Prepare for Addendum. \\
\hline 1.0 Site Characteristics & No & \\
\hline 2.0 Facility Description & & Modify as Required \\
\hline Process Description & Yes & Describe PWR operations. \\
\hline 3.0 Hazard and Accident Analysis & Yes & See sections below. \\
\hline $3.1 \& 3.2$ Introduction and Requirements & No & \\
\hline 3.3 Hazard Analysis & & \\
\hline 3.3.1 Methodology & No & \\
\hline 3.3.2 Hazard Analysis Results & Yes & $\begin{array}{l}\text { Determine PWR related Hazards. } \\
\text { Determine impact of PWR inventory on CSB facility hazard } \\
\text { categorization. } \\
\text { Perform PHA evaluation of PWR related hazards and compare to CSB } \\
\text { PHA. Add PWR unique events to CSB PHA table. } \\
\text { Integrate PWR events into CSB accident bins. } \\
\text { Identify those PWR related accidents requiring formal analysis. }\end{array}$ \\
\hline 3.4 Accident Analysis & & \\
\hline 3.4.1 Methodology & No & \\
\hline 3.4.2 Design Base Accidents & Yes & $\begin{array}{l}\text { Analyze accidents identified in Section } 3.3 . \\
\text { Identify any additional safety SSCs and potential TSRs. }\end{array}$ \\
\hline 3.4.3 Beyond Design Base Accidents & No & \\
\hline $4.0 \quad$ Safety SSCs & No & No additional SSCs anticipated. \\
\hline 5.0 Derivation of TSRs & Yes & Modify, if needed, based on input from Section 3.4.2. \\
\hline
\end{tabular}


Table 9-4. CSB SAR Addendum Evaluation Sheet, PWR-2 Operation. (2 sheets)

\begin{tabular}{|c|c|c|c|}
\hline (:) & Gontent? & Qlanga & Hodifichtion \\
\hline 6.0 & Prevention of Inadvertent Criticality & Yes & Discuss results of CSER. \\
\hline 7.0 & Radiation Protection & No & No new requirements anticipated. \\
\hline 8.0 & Hazardous Material Protection & No & No hazardous materials are being introduced by PWR operation. \\
\hline 9.0 & $\begin{array}{l}\text { Radioactive and Hazard Material } \\
\text { Waste Management }\end{array}$ & No & No new requirements anticipated. \\
\hline 10.0 & $\begin{array}{l}\text { Initial Testing In-Service Surveillance } \\
\text { and Maintenance }\end{array}$ & No & No new requirements anticipated. \\
\hline 11.0 & Operational Safety & No & No new requirements anticipated. \\
\hline 12.0 & Procedures and Training & No & No new requirements anticipated. \\
\hline 13.0 & Human Factors & No & No new requirements anticipated. \\
\hline 14.0 & $\mathrm{QA}$ & No & No new requirements anticipated. \\
\hline 15.0 & Emergency Preparedness Program & No & No new requirements anticipated. \\
\hline 16.0 & Provisions for $D \& D$ & No & No new requirements anticipated. \\
\hline 17.0 & $\begin{array}{l}\text { Management/Organization and } \\
\text { Institutional Safety Provisions }\end{array}$ & Yes & Describe unique organizational interfaces \\
\hline
\end{tabular}

${ }^{1}$ Documentation needs will be reviewed and revised, as appropriate, when the start of the safety document is started based on the then current design and operations. 
b. Upon arrival at the CSB, the operations to place the T Plant Canister in a vault tube are essentially the same as the operations followed to initially place the $\mathrm{K}$ Basin $\mathrm{MCO}$ in a vault tube for temporary storage prior to the hot vacuum treatment. The hazard analysis events should be similar.

c. MCO/canister design and acceptance considerations le.g., thermal cooling in a vault tube, long term structural and thermal effects, etc.) are addressed separately from the safety analysis documentation lalthough they might be referenced).

It is recommended that an amendment package to the CSB SAR for PWR-2 fuel assembly storage at the CSB be prepared.

\subsection{AMENDMENT PACKAGE SUMMARY}

Table 9-6 is a summary of the estimated cost and elapsed time required to complete the amendment packages for transferring the PWR-2 fuel assemblies from T Plant to the CSB vault.

Table 9-6. Estimated Cost and Time for PWR-2 Fuel Assembly Transfer Safety Basis Amendment Packages.

\begin{tabular}{|c|c|c|c|}
\hline 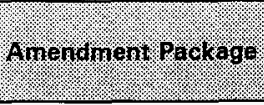 & estingated coss & 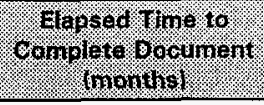 & 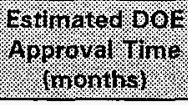 \\
\hline T Plant ISB & $\$ 110,000$ & 8 & 3 \\
\hline MCO Cask SARP & \multicolumn{3}{|c|}{ Responsibility of SNFP } \\
\hline CSB SAR & \multicolumn{3}{|c|}{ Responsibility of SNFP } \\
\hline
\end{tabular}


This page intentionally left blank. 


\subsection{ENVIRONMENTAL COMPLIANCE}

\subsection{NATIONAL ENVIRONMENTAL. POLICY ACT}

The NEPA requirements must be satisfied in order to transfer the PWR-2 fuel assemblies from T Plant to the CSB. At present, two EISs have been prepared that address movement of SNF at Hanford. Neither of these EISs specifically covers the PWR-2 fuel assembly transfer to the CSB.

The first is a Programmatic EIS (DOE 1995c) for SNF that includes Hanford and other DOE sites. This EIS originally proposed that the PWR-2 fuel assemblies at T Plant be shipped to the Idaho National Engineering Laboratory. This proposal was subsequently changed in an agreement to modify the Programmatic EIS Record of Decision (ROD) (DOE 1996b). Under the change, SNF not requiring treatment (including the PWR-2 fuel assemblies) would remain at Hanford.

The second SNF EIS is specific to the fuel currently stored in the Hanford K Basins (DOE 1996a). This EIS addresses the packaging and transfer of K Basins fuel to the CSB, but does not address any of the "other" SNF stored at Hanford. Approximately 2,100 metric tons of uranium metal fuel will be transferred from the K Basins. Other SNF includes an additional 29 metric tons of heavy metal fuel stored in the 200,300, and 400 areas. Of this 29 metric tons, the PWR-2 fuel assemblies account for about 16 metric tons.

The Programmatic EIS contains a commitment for other potential tiered NEPA reviews for proposed SNF activities not already covered. The transfer of PWR-2 fuel assemblies from T Plant to the CSB falls into this category. NEPA reviews have not been completed for interim actions for the PWR-2 fuel assemblies.

An evaluation of "other" SNF management at the CSB complex by WHC SNF Engineering was completed in February 1996 (McCormack 1996). This review recommended preparation of a single EA to address the impacts of interim management of the "other" Hanford SNF. The EA would be tiered from the existing SNF ElSs, since management of "other" fuel falls under the umbrella of the Programmatic EIS, and major activities in the CSB already addressed in the K Basins EIS. Using the tiered system, a project-specific EA would only focus on potential environmental impacts of the project that are not covered in umbrella documents (Government Institutes 1992). An EA generally results in a Finding of No Significant Impact (FONSI) or a determination that potential impacts are significant. If the potential impacts are significant, preparation of an EIS would be required.

The evaluation of "other" SNF (McCormack 1996) estimated that the EA could be prepared in less than 12 months, perhaps in 4 to 6 months. The cost of the EA might not be charged solely to the PWR-2 fuel assemblies effort at T Plant since it would also address "other" Hanford fuels. 


\subsection{PERMITTING}

\subsubsection{Resource Conservation and Recovery Act/Dangerous Waste Permitting} Requirements

The RCRA Subtitle C Hazardous Waste Regulations and the Washington Department of Ecology Dangerous Waste Regulations (WAC-173-303) do not apply to the PWR-2 fuel assemblies. The fuel has not been declared to be a waste (McCormack 1996).

Any hazardous or dangerous waste generated during the transfer of the PWR-2 fuel assemblies from $T$ Plant would have to be appropriately dispositioned to permitted facilities, which are in-place at Hanford.

\subsubsection{Air Permitting}

The PWR-2 fuel assemblies are assumed to be in good condition with intact cladding. As a result, no special modifications to the Hanford Air Operating Permit (not yet issued / would be needed for packaging and transfer to the CSB. According to 40 CFR 61 Subpart H, Hanford stacks are "major" or "minor" sources depending on whether they could potentially discharge enough radioactivity to cause a dose to the public of more than $0.1 \mathrm{mrem} /$ year. T Plant is currently considered a minor source. If upgraded to a major source, additional requirements for ANSI-compliant monitoring would be imposed on the facility. This is not likely to happen because the PWR-2 fuel is sealed inside the cladding, and the fuel assemblies may be considered sealed sources.

An increase in potential emissions from T Plant during fuel removal could only occur if contamination, "crud," on the surface of the fuel became airborne (see Section 6.7). Since the fuel assemblies will be wet and the crud contamination assumed to be of small quantity (not present as a dust), an increase in T Plant emissions is not likely. However, documentation of fuel removal plans for T Plant should be provided to the Air and Water Permitting organization for concurrence. The PWR-2 fuel assemblies will not be repackaged at the $\mathrm{CSB}$, so a permit for repackaging will not be needed.

A modification to the NOC for the CSB will need to be prepared to account for the increased SNF inventory to be stored (McCormack 1996). The final phase of the NOC for the CSB is now in progress. Modifying the NOC will be a minor activity.

\subsubsection{Cultural Resources Review}

T Plant is listed on the National Register of Historic Places for its role in World War II as a separations facility. As a result, any planned physical modifications to the building must be described and a diagram of the affected area submitted for review per the draft Agreement for the Built Environment ... on the Hanford Site. According to the draft agreement, such a review would not be needed if the fuel will be moved after the year 2000. In any case, removing the PWR-2 fuel assemblies will not affect the World War II character of T Plant since modifications to store the fuel were made after T Plant 
ended its separations mission. Also, the total cost of the review would be small, less than $\$ 2,000$ for all parties involved. 
This page intentionally left blank. 


\subsection{SAFEGUARDS AND ACCOUNTABILITY}

This section describes the storage and transfer safeguards, and the accountability measures required to implement the transfer of PWR-2 fuel assemblies from the T Plant storage pool to the CSB.

\subsection{SAFEGUARDS}

Currently, the PWR-2 fuel assemblies are considered self protecting and are classified as Category IV-E per Control and Accountability of Nuclear Materials (DOE Order $5633.3 \mathrm{~B}$ ). They are considered seif protecting because the external radiation dose at $1 \mathrm{~m}$ $(3.3 \mathrm{ft})$ from a single blanket fuel assembly is greater than $100 \mathrm{rem} / \mathrm{hr}$. However, as stated in Section 6.4.1, the fuel assemblies are expected to cease being self protecting (less than $100 \mathrm{rem} / \mathrm{hr}$ ) in 2004 and would be reclassified as Category II SNF.

As stated in General Design Criteria (DOE Order 6430.1A), category III nuclear material is required to be stored in a protected area or other security area that has a clearly defined perimeter barrier, personnel and vehicle access control at the entrance, and search procedures. Category II nuclear materials are stored in vaults, vault-type rooms, or security containers, which are protected with DOE approved intrusion alarm systems. Category I nuclear materials are stored in vaults or vault-type rooms equipped with intrusion alarm systems. When the CSB storage bays are complete, they will be capable of storing Category II quantities of nuclear material.

For the purposes of this plan, it is assumed the PWR-2 fuel assemblies will still be self protecting when they are transferred out of $T$ Plant. It is also assumed that the fuel assemblies will only be transferred to the CSB storage bays for interim storage. According to security personnel, no extraordinary security measures (e.g., armed escorts, helicopters, etc.) are required during shipment of the assemblies from T Plant to the CSB.

\subsection{ACCOUNTABILITY}

Accountable materials (including nuclear materials and special nuclear materials) are controlled and accounted for as directed by DOE 5633.3 (DOE 1994) and WHC-CM-4-34 (WHC 1992). Material shipments and transfers must be documented and controlled in conformity with these documents. Additionally preliminary requirements for the disposition of DOE Spent Nuclear fuel in a deep geologic repository have been issued (DI:

A00000000-00811-1708-00006 Rev 0). As stated in Section 6.8, a technical data (characterization) package meeting the requirements for deep geologic repository disposal must be prepared and accompany T Plant fuel transfers to the CSB.

Each PWR-2 fuel assembly was marked during construction with a distinct assembly identification number on the top of the top extension bracket (see Figure 12-1). The identification number was engraved using a carbide tipped vibra-tool using $1 / 8$ inch high letters, 1/32 inch deep. The identification numbers contain both letters and numbers and are sequenced as " $X-X X-X X X-X X$." This identification number is also engraved on the side of the fuel cluster, just below the top extension. Both numbers are located on the same 
side of the fuel assembly. An example of a PWR-2 fuel assembly identification number was obtained from the unirradiated fuel assembly discussed in Section 6.6.3. The identification number was read to be "G-2A-FO1-04," as shown in Figure 11-1. However, because of the etching quality and poor photographic resolution, this number should be deemed suspect. The same problem will probably occur when reading PWR-2 fuel assembly identification numbers within the T Plant Canister.

Figure 11-1. PWR-2 Fuel Assembly Identification Number Location.

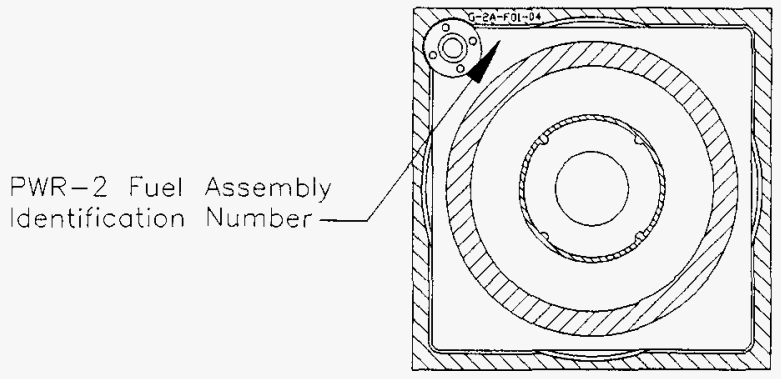

During PWR-2 fuel assembly transfer operations from the T Plant storage pool to the $T$ Plant Canister, every effort will be made to record the identification number on each fuel assembly before the canister shield plug is inserted. The ideal time and location for this identification should be after the final (fourth) fuel assembly has been inserted into the canister. At this time the bridge crane video camera should zoom in on the top extensions of each of the four fuel assemblies, focusing on the four identification numbers. Care will be taken to obtain the best angle and lighting to read each of the identification numbers. After insertion of the canister shieid plug, the T Plant Canister serial number will also be recorded by the bridge crane camera immediately after insertion and on the same video tape as the fuel assembly recording.

Before PWR-2 fuel assembly transfer operations begin, the tops of the fuel assemblies will be inspected within the T Plant storage pool to determine the readability of the identification numbers. Any material buildup on top of the fuel assemblies will be removed and the identification numbers wiped clean before transfer operations begin. If the identification numbers of the four fuel assemblies to be transferred are readable while still within the storage pool, they will be recorded by the bridge crane camera or by operators. However, video documentation of the four fuel assemblies within their respective canister will also take place. 


\subsection{REMOVAL OF T PLANT POOL WATER AND ION EXCHANGE COLUMN}

\subsection{REMOVAL AND DISPOSAL OF STORAGE POOL WATER}

According to DOE Order 5400.5 (DOE 1993d) and current storage water characteristics (see Tables 8-1 and 8-2), the 190,000 L (50,000 gal) of water currently being used for shielding and cooling of the PWR-2 fuel assemblies will be treated and disposed by the Effluent Treatment Facility (ETF). At the time of D\&D, this assumption should be reevaluated. However, it is assumed for this plan that the storage pool water will be sent to the ETF.

There is currently no formal acceptance criteria for the shipment of wastewater to the ETF complex for treatment and disposal. Currently, wastewater transfer approva! involves the DOE agencies overseeing the ETF and the wastewater generator preparing and approving a Memorandum of Understanding. This memorandum would clarify the overall liquid volume, contaminate concentration, type of contaminates, and reimbursement of ETF expenses. The ETFs liquid discharge permit would also need to be modified to reflect this unique liquid waste stream. However, the cost for modifying this permit would be small (approximately 2 man weeks). No cost schedule for treatment of liquid waste at the ETF complex is currently available. However, given the volume and low contaminate concentrations, ETF personnel have estimated the treatment time as approximately one day. The cost of operating ETF for one day is estimated to range from $\$ 10,000$ to $\$ 50,000$.

According to ETF personnel, there are no perceived scheduling problems associated with the ETF acceptance of the PWR-2 storage pool water currently or through the year 2005.

\subsubsection{Storage Pool Draining Preparation}

Although process knowledge and current cobalt-60 and cesium- 137 analysis indicate very little storage pool water activity $\left(<10^{-5} \mu \mathrm{Ci} / \mathrm{ml}\right)$, to obtain ETF acceptance, the radionuclides content will be further characterized. Additional radiochemical analysis desired includes GEA, ${ }^{3} \mathrm{H},{ }^{90} \mathrm{Sr},{ }^{99} \mathrm{Tc},{ }^{129} /{ }^{238} \mathrm{Pu},{ }^{239} \mathrm{Pu},{ }^{240} \mathrm{Pu},{ }^{241} \mathrm{Pu},{ }^{237} \mathrm{~Np},{ }^{241} \mathrm{Am}$, and ${ }^{244} \mathrm{Cm}$. The possibility of sampling the storage pool walls and floor will also be explored to determine water quality after storage pool decontamination. Process knowledge appears to be sufficient to conclude that the storage pool water would not be classified as a hazardous waste.

Before the storage pool is drained, it will be verified that the water is not providing shielding for any known or unknown crud, debris, or other radioactive materials that remain within the storage pool after PWR-2 fuel removal. The storage pool walls and floor, the fuel rack, and any other equipment that will remain within the storage pool after fuel removal will be shown to pose no personnel exposure problem without the water shielding. If it is determined that there will be unacceptable exposure levels, the "hot" items will be removed and disposed of according to appropriate solid waste procedures. If it is determined that the storage pool walls and/or floor pose an exposure problem, the walls and floor will be mechanically and/or chemically decontaminated. 


\subsubsection{Storage Pool Water Transfer}

Based on process history and current water quality analysis, the storage pool water can be classified as "Low Specific Activity, Category 2." It is assumed for this plan that the storage pool water will be transported to the ETF complex (northeast corner of the 200 East Area) in an ETF supplied 5,000 gal double-shell tanker truck.

The tanker truck will enter T Plant via the railroad access tunnel. The truck will be positioned and the wheels blocked prior to storage pool water transfer. A $380 \mathrm{~L} / \mathrm{min}$ $(100 \mathrm{gpm})$ submersible pump will be installed in the storage pool to transfer the pool water to the tanker truck. This process should require approximately 60 minutes for each $19,000 \mathrm{~L}(5,000 \mathrm{gal})$ transfer.

Radiation levels above the descending pool level will be surveyed during transfer activities to determine if the lowering water level is exposing undiscovered "hot spots." If a hot spot is discovered, the draining process will be immediately stopped and the situation evaluated. The situation will be resolved before storage pool draining operations may proceed. After a tanker truck has been filled, the transfer pump will be shut down and the water line valves closed to prevent any siphoning of the storage pool water to the tunnel.

\subsubsection{Tanker Truck Clearance}

Once the tanker truck has been filled, transfer hoses disconnected and removed, and tank access ports closed the tanker truck will be prepared for transport to the ETF. However, before the tanker truck is actually cleared for transport, the appropriate approvals from T Plant and the ETF will be completed and appropriate notifications given.

\subsection{REMOVAL AND DISPOSAL OF PWR-2 ION EXCHANGE COLUMN}

According to the Hanford Site Solid Waste Acceptance Criteria (WHC 1993) and past practice disposal, the PWR-2 ion exchange column will be disposed of in the low-level solid waste burial grounds as low-level radioactive solid waste. Given the contact radiation limit of $230 \mathrm{mr} / \mathrm{hr}$ for an unshielded PWR-2 ion exchange column (per operating specifications OSD-D-187-00008), the column is classified as a Category 1 low-level waste per cobalt-60 and cesium-137 activity limits. Periodically in the past ion exchange columns have been disposed of because current PWR-2 ion exchange operating procedures do not require regeneration. Two PWR-2 ion exchange columns were removed from the T Plant canyon in January 1994 and disposed of as low-level waste. Waste characterization for these two columns was based on contact dose rates, storage pool historical activity levels, and process knowledge of the PWR-2 storage system. Since activity levels within the storage pool have decreased at least one order of magnitude since $1994\left(1.2 \times 10^{-4}\right.$ to $\left.9.79 \times 10^{-6} \mu \mathrm{Ci} / \mathrm{mi}\right)$, it is assumed that future disposal of ion exchange columns can also be disposed of as low-level, Category 1 , radioactive waste, barring unforeseen upsets to the PWR-2 storage pool system. These conclusions should be reevaluated at the time of actual disposal. 
To dispose of solid waste at the Hanford Site, the following forms must be completed per Appendix A of the Acceptance Criteria Document:

- Waste Storage/Disposal Request

- Solid Waste Storage/Disposal Record

For detailed instructions in the disposal of the PWR-2 ion exchange column, see Sections 2 and 3 of the Solid Waste Acceptance Criteria document.

The cost for disposal of Category 1, low-level solid waste is currently $\$ 17.50 / \mathrm{ft}^{3}$. If the waste contains flammable and/or Category 3 material, the cost for disposal increases to between $\$ 70$ and $\$ 100 / \mathrm{ft}^{3}$.

\subsubsection{PWR-2 Ion Exchange Column Description}

Table 12-1 outlines details of the PWR-2 ion exchange columns. Further information can be found in drawings $\mathrm{H}-2-70818, \mathrm{H}-2-70819$, and $\mathrm{H}-2-70820$.

Table 12-1. PWR-2 lon Exchange Column Information.

\begin{tabular}{|c|c|c|}
\hline Construction & \multicolumn{2}{|c|}{$\begin{array}{l}\text { Vertical cylindrical tank with cylindrical bottom } \\
\text { and top. }\end{array}$} \\
\hline Length & \multicolumn{2}{|c|}{$\begin{array}{l}151.1 \mathrm{~cm}(59.5 \mathrm{in.}) \text { plus the } 13 \mathrm{~cm}(5 \mathrm{in.}) \text { lifting } \\
\text { ring and } 13 \mathrm{~cm}(5 \mathrm{in.}) \text { support feet. }\end{array}$} \\
\hline Diameter & \multicolumn{2}{|l|}{$46 \mathrm{~cm} \mathrm{(18} \mathrm{in.)}$} \\
\hline Construction Material and Thickness & \multicolumn{2}{|l|}{ 304L Stainless Steel ( $1 / 4$ in.) } \\
\hline Weight & $\begin{array}{l}\text { Empty Column } \\
\text { Column Filled with Water } \\
\text { Resin Charge }\end{array}$ & $\begin{array}{l}145 \mathrm{~kg}(320 \mathrm{lb}) \\
364 \mathrm{~kg}(800 \mathrm{lb}) \\
102 \mathrm{~kg}(225 \mathrm{lb})\end{array}$ \\
\hline Ports & \multicolumn{2}{|l|}{$\begin{array}{l}1-1 / 6 \text { in vent } \\
1-3 \text { in top inlet } \\
1-1 \text { in bottom outlet }\end{array}$} \\
\hline Ion Exchange Resins & $\begin{array}{l}\text { IRA-938 } \\
\text { IRN-150 } \\
\text { Charcoal } \\
\text { Total }\end{array}$ & $\begin{array}{l}L\left(1.3 \mathrm{ft}^{3}\right) \\
L\left(2.3 \mathrm{ft}^{3}\right) \\
L\left(1.4 \mathrm{ft}^{3}\right) \\
L\left(5.0 \mathrm{ft}^{3}\right)\end{array}$ \\
\hline Shielding & \multicolumn{2}{|c|}{$\begin{array}{l}41 \mathrm{~cm}(16 \text { in.) reinforced concrete } \\
\text { with removable lid. }\end{array}$} \\
\hline
\end{tabular}

\subsubsection{Ion Exchange Column Preparation}

The PWR-2 ion exchange column will be removed from its concrete shielding box. This would include removing the shielding box lid, disconnecting the column from the process piping, draining the column of all liquid, and removing the column completely from the shielding box. Once the column has been removed from the shielding box, a radiation 
survey will be completed to determine the surface dose rates. If the overall dose rate is within acceptable limits the void spaces in the column will be filled with clean cat litter or some oțher filler material as specified in Appendix $G$ of the Solid Waste Acceptance Criteria. This requirement can be ignored if through evaluation the column and/or the disposal container can be shown to not cause subsidence when buried. If the overall column dose rate is too high for worker exposure, remote handling of the column will be required. In addition, if the maximum surface (outer column shell) dose rate should exceed $1,000 \mathrm{mr} / \mathrm{hr}$, the Category 1 classification should be reevaluated.

\subsubsection{Ion Exchange Column Transfer}

Once the void space within the ion exchange column has been filled, it can be transferred to a standard burial ground shipping and disposal container $11.2 \mathrm{~m}$ by $1.2 \mathrm{~m}$ by $2.4 \mathrm{~m} \mathrm{[} 4 \mathrm{ft}$ by $4 \mathrm{ft}$ by $8 \mathrm{ft}$ ] plywood box). Again, the void space within the burial ground container will be filled with an approved material as listed in Appendix G (WHC 1993). If any other Category 1 solid waste within the $T$ Plant canyon also requires disposal and meets the Hanford acceptance criteria, it may also be disposed of within the column disposal container.

The ion exchange column/container can be transferred from $T$ Plant to the burial ground location using a standard flatbed truck (assuming Category 1 compliance). The truck will enter T Plant through the same tunnel entrance as the cask transporter. The trucks will be backed in and the wheels blocked prior to ion exchange column transfer. The shipping and disposal container will be preloaded onto the truck prior to entering $T$ Plant and will be ready to receive the column. If any additional solid material (such as other storage pool equipment) will be added to the container, it will be predetermined that no interferences will be placed on the loading of the column.

Once the column has been transferred to the shipping and disposal container, the container void space filled, and container lid attached and sealed the flatbed truck will be prepared for transport to the Hanford Site burial grounds. Before the truck is actually cleared for transport, the appropriate approvals from T Plant and the Burial Grounds will be completed and appropriate notifications given. 


\subsection{TRANSFER SCHEDULE}

Two schedules are attached for the transfer of the PWR-2 fuel elements from T Plant to the CSB. The first schedule (Figure 13-1) assumes that transfers of PWR-2 fuel from $T$ Plant to the CSB cannot commence until after $K$ Basin transfers are complete. This is the current plan option. It shows completion of PWR-2 transfers by March 13, 2001.

The second schedule (Figure 13-2) assumes no ties with the $K$ Basin SNF retrieval project other than the availability of the $K$ Basin transporters and casks. This schedule is provided for information only and is not the recommended option. It shows completion of PWR-2 transfers by November 3, 1999. 
Fig 13-1 T PLANT FUEL ASSEMBLIES REMOVAL (FOLLOWING K BASIN SNF RETRIEVAL) Summary Schedule

\begin{tabular}{|c|c|c|c|c|c|c|c|c|c|c|c|c|c|c|c|}
\hline \multirow[b]{2}{*}{ ID } & \multirow{2}{*}{ Task Name } & \multirow[b]{2}{*}{ Days } & \multirow[b]{2}{*}{ Start } & \multicolumn{2}{|l|}{96} & \multicolumn{2}{|l|}{97} & \multicolumn{3}{|c|}{98} & 99 & & \multicolumn{2}{|c|}{00} & \multirow[b]{2}{*}{1} \\
\hline & & & & \begin{tabular}{|l|l|l|}
4 & 7 \\
\end{tabular} & 10.1 1 & \begin{tabular}{l|l|l|}
1 & 4 & 7 \\
\end{tabular} & 10 & 1 & \begin{tabular}{|l|l|l|}
4 & 7 & 10 \\
\end{tabular} & $\begin{array}{ll}10 & 1 \\
\end{array}$ & \begin{tabular}{l|l|l|l|}
1 & 4 & .7 & 10 \\
\end{tabular} & 10.1 & $9 \sqrt{4}$ & \begin{tabular}{|l|l|l|}
7 & 10 & 1 \\
\end{tabular} & \\
\hline 1 & Project Documentation & $247 d$ & $10 / 1 / 96$ & & & & & & & & & & & & \\
\hline 2 & Issue Project Task Authorization & $34 d$ & $10 / 1 / 96$ & & ש & & & & & & & & & & \\
\hline 3 & Produce Project QA Plan & $27 d$ & $11 / 18 / 96$ & & - & & & & & & & i & & & \\
\hline 4 & Preliminary Hazards Analysis & $100 d$ & $1 / 2 / 97$ & & & & & & & & & & & & \\
\hline 5 & Fuel Assembly Characterization Report & $40 d$ & $5 / 23 / 97$ & & & - & & & & & & . & & & \\
\hline 6 & SNF Technical Data Package & $40 \mathrm{~d}$ & $7 / 17 / 97$ & & & - & & & & & & & & & \\
\hline 7 & Safety Basis Documentation & $763 d$ & $1 / 2 / 97$ & & & & & & & & & & & & \\
\hline B & T Plant ISB (Addendum) & $763 d$ & $1 / 2 / 97$ & & & & & & & & & & & & \\
\hline 9 & SARP (Addendum) & $763 d$ & $1 / 2 / 97$ & & & & & & & & & & & & \\
\hline 10 & CSB SAR (Addendum) & $763 d$ & $1 / 2 / 97$ & & & & & & & & & & & & \\
\hline 11 & Criticality Evaluation & $205 d$ & $1 / 2 / 97$ & & & & & & & & & & & & \\
\hline 12 & ALARA Plan & 205d & $1 / 2 / 97$ & & & & & & & & & & & & \\
\hline 13 & Environmental Compliance Documentation & 175d & $1 / 2 / 97$ & & & & & & & & & & & & \\
\hline 14 & Environmental Assessment & 1750 & $1 / 2 / 97$ & & & & & & & & & & & & \\
\hline 15 & CSB Notice of Construction & $130 \mathrm{~d}$ & $1 / 2 / 97$ & & & & & & & & & & & & \\
\hline 16 & Cultural Resources Review & 10d & $1 / 2 / 97$ & & & & & & & & & & & & \\
\hline 17 & Fuel Assembly Characterization & 60d & $3 / 3 / 97$ & & & & & & & & & & & & \\
\hline$\$ 8$ & New Equipment (Design, Build, Test) & $200 d$ & $3 / 31 / 97$ & & & & & & & & & & & & \\
\hline 19 & Primary and Secondary Grapples & 200d & $3 / 31 / 97$ & & & & & & & & & & & & \\
\hline 20 & 3-Ton Hoist & $175 d$ & $3 / 31 / 97$ & & & & & & & & & & & & \\
\hline 21 & Cask Lid Grapple & 60d & $3 / 31 / 97$ & & & & & & & & & & & & \\
\hline 22 & Grapple Stand & $200 d$ & $3 / 31 / 97$ & & & & & & & & & & & & \\
\hline 23 & T Plant Canister Lid Grapple & $60 d$ & $3 / 31 / 97$ & & & $m$ & & & & & & & & & \\
\hline 24 & T Plant Canister Container \& Shield Plug & 200d & $3 / 31 / 97$ & & & & & & & & & & & & \\
\hline 25 & Vacuum Drying Equipment & $100 d$ & $3 / 31 / 97$ & & & & & & & & & & & & \\
\hline 26 & T Plant Canister Loading Guide & 2000 & $3 / 31 / 97$ & & & & & & & & & & & & \\
\hline 27 & Transport Route/Equipment & $200 d$ & $3 / 23 / 98$ & & & & & & & & & & & & \\
\hline 28 & Cask \& Transp Eqpt (Existing/Available) & Od & $3 / 23 / 98$ & & & & & $\bullet$ & & & & & & & \\
\hline 29 & Upgrades to Route/Utilities (Des/Constr.) & $200 \mathrm{~d}$ & $3 / 23 / 98$ & & & & & & & & & & & & \\
\hline 30 & Prep. of Operational Documentation & $190 \mathrm{~d}$ & $10 / 1 / 98$ & & & & & & & & & & & & \\
\hline 31 & Training Manuals & $100 d$ & $10 / 1 / 98$ & & : & & & & & & & & & & \\
\hline 32 & Operational/Maintenance Procedures & $190 d$ & $10 / 1 / 98$ & & & & & & & & & & & & \\
\hline 33 & Health Physics Procedures & $20 d$ & $10 / 1 / 98$ & & & & & & - & & & & & & \\
\hline 34 & Start-up Activities & 233d & $5 / 7 / 99$ & & & & & & & & & & & & \\
\hline 35 & Start-up Documentation (ATP) & $120 \mathrm{~d}$ & $5 / 7 / 99$ & & & & & & & & & & & & \\
\hline 36 & Manufacture (4) Simulated Fuel Assemblies & 90d & $5 / 7 / 99$ & & & & 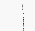 & & & & & & & & \\
\hline 37 & Start-up Testing (Non Radioactive) & $30 d$ & $10 / 22 / 99$ & & $\vdots$ & & & & & & & - & & & \\
\hline 38 & Training & 20d & $12 / 22 / 99$ & & & & 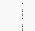 & & & & & - & & & \\
\hline 39 & Operational Readiness Review (ORR) & $30 d$ & $1 / 19 / 00$ & & & & & & & & & $\bullet$ & & & \\
\hline 40 & Start-up (Fill First MCO) & 20d & $3 / 1 / 00$ & & & & & & & & & - & - & & \\
\hline 41 & SNF Removal Activities & $119 d$ & $10 / 2 / 00$ & & & & & & & & & & & & \\
\hline $\mathbf{d 2}$ & Operations at T Plant & $119 d$ & $10 / 2 / 00$ & & & & & & & & & $\vdots$ & & & \\
\hline 43 & Transportation to CSB & $119 \mathrm{~d}$ & $10 / 2 / 00$ & & & & & & & & & & & & \\
\hline 44 & Operations at CSB & $119 d$ & $10 / 2 / 00$ & & & & & & & & & $\therefore$ & & & \\
\hline 45 & D\&D Activities & 49d & $4 / 3 / 01$ & & & & & & & & & $\because$ & & & \\
\hline 46 & Remove Pool Water from T Plant & 400 & $4 / 3 / 01$ & & & & & & & & & : & & & $=$ \\
\hline 47 & Remove Ion Exchange Column & 400 & $4 / 16 / 01$ & & & & & & & & & & & & $=$ \\
\hline 48 & Task Complete & od & $6 / 8 / 01$ & & & & & & & & & 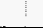 & & & $v$ \\
\hline
\end{tabular}


Fig 13-2 T PLANT FUEL ASSEMBLIES REMOVAL (CONCURRENT WITH K BASIN SNF RETRIEVAL) Summary Schedule

\begin{tabular}{|c|c|c|c|c|c|c|c|c|c|c|c|c|c|c|c|c|c|c|c|}
\hline \multirow[b]{2}{*}{10} & \multirow{2}{*}{ Task Name } & \multirow[b]{2}{*}{ Days } & \multirow[b]{2}{*}{ Start } & \multicolumn{3}{|c|}{96} & \multicolumn{4}{|c|}{97} & \multicolumn{4}{|c|}{98} & \multicolumn{4}{|c|}{99} & \multirow[b]{2}{*}{1} \\
\hline & & & & 4 & 7 & 10 & 1 & 4 & 7 & 10 & 1 & 4 & 7 & 10 & 1 & 4 & 7.1 & 10 & \\
\hline 1 & Project Documentation & 247d & $10 / 1 / 96$ & & & & & & & & & & & & & & & & \\
\hline 2 & Issue Project Task Authorization & $34 d$ & $10 / 1 / 96$ & & & - & & & & & & & & & & & & & \\
\hline 3 & Produce Project QA Plan & 27d & $11 / 18 / 96$ & & & 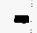 & & & & & & & & & & & & & \\
\hline 4 & Preliminary Hazards Analysis & $100 d$ & $1 / 2 / 97$ & & & & & & & & & & & & & & & & \\
\hline 5 & Fuel Assembly Characterization Report & $40 \mathrm{~d}$ & $5 / 23 / 97$ & & & & & & & & & & & & & & & & \\
\hline 6 & SNF Technical Data Package & 40d & $7 / 17 / 97$ & & & & & & r & & & & & & & & & & \\
\hline 7 & Safety Basis Documentation & $517 d$ & $1 / 2 / 97$ & & & & & & & & & & & & & & & & \\
\hline 8 & T Plant ISB (Addendum) & 517d & $1 / 2 / 97$ & & & & & & & & & & & & & & & & \\
\hline 9 & SARP (Addendum) & $517 d$ & $1 / 2 / 97$ & & & & & & & & & & & & & & & & \\
\hline 10 & CSB SAR (Addendum) & 517d & $1 / 2 / 97$ & & & & & & & & & & & & & & & & \\
\hline 11 & Criticality Evaluation & 205d & $1 / 2 / 97$ & & & & & & & & & & & & & & & & \\
\hline 12 & ALARA Plan & 2050 & $1 / 2 / 97$ & & & & & & & & & & & & & & $\cdots$ & & \\
\hline 13 & Environmental Compliance Documentation & $175 d$ & $\$ / 2 / 97$ & & & & & & & & & & & & & & & & \\
\hline 14 & Environmental Assessment & $175 d$ & $1 / 2 / 97$ & & & & & & & & & & & & & & & & \\
\hline 15 & CSB Notice of Construction & $130 \mathrm{~d}$ & $1 / 2 / 97$ & & & & & & & & & & & & & & & & \\
\hline 16 & Cultural Resources Review & 100 & $1 / 2 / 97$ & & & 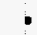 & & & & & & & & & & & & & \\
\hline 17 & Fuel Assembly Characterization & $60 d$ & $3 / 3 / 97$ & & & & & & & & & & & & & & & & \\
\hline 18 & New Equipment (Design, Build, Test) & $200 \mathrm{~d}$ & $3 / 31 / 97$ & & & & & & & & & & & & & & & & \\
\hline 19 & Primary and Secondary Grapples & $200 d$ & $3 / 31 / 97$ & & & & & & & & & & & & & & & & \\
\hline 20 & 3-Ton Hoist & $175 d$ & $3 / 31 / 97$ & & & & & & & & & & & & & & & & \\
\hline 21 & Cask Lid Grapple & 60d & $3 / 31 / 97$ & & & & & & & & & & & : & & & & : & \\
\hline 22 & Grapple Stand & 200d & $3 / 31 / 97$ & & & & & & & & & & & & & & & : & \\
\hline 23 & T Plant Canister Lid Grapple & 600 & $3 / 31 / 97$ & & & & & & & & & & & & & & & & \\
\hline 24 & T Plant Canister Container \& Shield Plug & $200 \mathrm{~d}$ & $3 / 31 / 97$ & & & & & & & & & & & & & & & & \\
\hline 25 & Vacuum Drying Equipment & $100 d$ & $3 / 31 / 97$ & & & & & & & & & & & & & & & & \\
\hline 26 & T Plant Canister Loading Guide & $200 d$ & $3 / 31 / 97$ & & & & & & & & & & & & & & & & \\
\hline 27 & Transport Route/Equipment & $200 d$ & $3 / 31 / 97$ & & & & & & & & & & & & & & & & \\
\hline 28 & Cask \& Transp Eqpt (Existing/Available) & od & $3 / 31 / 97$ & & & & $\bullet$ & & & & & & & & & & & & \\
\hline 29 & Upgrades to Route/Utilities (Des/Constr.) & $200 d$ & $3 / 31 / 97$ & & & & & & & & & & & & & & & & \\
\hline 30 & Prep. of Operational Documentation & 190d & $1 / 2 / 98$ & & & & & & & & & & 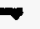 & 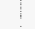 & & & & & \\
\hline 31 & Training Manuals & $100 d$ & $1 / 2 / 98$ & & & & & & & & & ש & & & & & & & \\
\hline 32 & Operational/Maintenance Procedures & $190 \mathrm{~d}$ & $1 / 2 / 98$ & & & & & & & & & & D & $\vdots$ & & & & & \\
\hline 33 & Health Physics Procedures & 200 & $1 / 2 / 98$ & & & & & & & $=$ & & & & 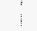 & & & & & \\
\hline 34 & Start-up Activities & $236 d$ & $5 / 1 / 98$ & & & & & & & & & & & & & & - ב- & & \\
\hline 35 & Start-up Documentation (ATP) & $120 d$ & $5 / 4 / 98$ & & & 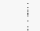 & & & & & & & & & & & & & \\
\hline 36 & Manufacture (4) Simulated Fuel Assemblies & $90 \mathrm{~d}$ & $5 / 1 / 98$ & & & : & & & & & & & & & & & & $\vdots$ & \\
\hline 37 & Start-up Testing (Non Radioactive) & $30 d$ & 10/16/98 & & & & & & & & & & - & & & & & & \\
\hline 38 & Training & $20 \mathrm{~d}$ & $12 / 21 / 98$ & & & & & & & & & & & 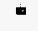 & & & & & \\
\hline 39 & Operational Readiness Review (ORR) & $30 \mathrm{~d}$ & $1 / 18 / 99$ & & & & & & & & & & & & 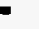 & & & & \\
\hline 40 & Start-up (Fill First MCO) & $20 \mathrm{~d}$ & $3 / 1 / 99$ & & & : & & & & & & & & & $=$ & & & & \\
\hline 41 & SNF Removal Activities & $119 d$ & $3 / 26 / 99$ & & & & & & & & & & & & & & & & \\
\hline 42 & Operations at T Plant & $119 d$ & $3 / 26 / 99$ & & & & & & & & & & & & & & & & \\
\hline 43 & Transportation to CSB & $119 d$ & $3 / 26 / 99$ & & & & & & & & & & & $\vdots$ & & & & & \\
\hline 44 & Operations at CSB & $149 d$ & $3 / 26 / 99$ & & & & & & & & & & & & & & & & \\
\hline 45 & D\&D Activities & $40 d$ & 9/9/99 & & & & & & & & & & & & & & & & \\
\hline 46 & Remove Pool Water from T Plant & $40 d$ & 9/9/99 & & & & & & & & & & & & & & $\square$ & & \\
\hline 47 & Remove Ion Exchange Column & $40 \mathrm{~d}$ & $9 / 9 / 99$ & & & & & & & & & & & & & & - & & \\
\hline 48 & Task Complete & od & $11 / 3 / 99$ & & & & & & & & & & & & & & & $\bullet$ & \\
\hline
\end{tabular}


This page intentionally left blank. 


\subsection{RETRIEVAL AND TRANSFER COST}

The T Plant related cost of PWR-2 fuel assembly removal from the. T Plant canyon is estimated to be $\$ 2.64$ million in FY-1996 dollars. This does not include the cost of activities directed by SNFP supporting PWR-2 fuel removal. This value includes a 22 percent contingency variance reflecting the uncertainties contained in this plan.

Table 14- 1 indicates the total project costs escalated by work years based on the schedule in Section 13.0 assuming a start date in 1996.

A breakdown of this estimate (13 pages) is appended to this section as Table 14-2.

Table 14-1. Cost of PWR-2 Removal (Following K Basin SNF Retrieval).

\begin{tabular}{|l|c|c|c|c|c|}
\hline \multicolumn{1}{|c|}{ Fiscal Year } & 1997 & 1998 & 1999 & 2000 & 2001 \\
\hline $\begin{array}{l}\text { Anticipated } \\
\text { Work } \\
\text { Completed (\$) }\end{array}$ & $\$ 599,219$ & $\$ 588,294$ & $\$ 436,273$ & $\$ 525,239$ & $\$ 489,011$ \\
\hline $\begin{array}{l}\text { Increased } \\
\text { G\&A/CSP }\end{array}$ & $1.0 \%$ & $3.0 \%$ & $3.0 \%$ & $3.0 \%$ & $3.0 \%$ \\
\hline $\begin{array}{l}\text { Escalation } \\
\text { Assumed from } \\
1996 \\
(2.7 \% / y r)\end{array}$ & $2.7 \%$ & $5.5 \%$ & $8.3 \%$ & $11.3 \%$ & $14.3 \%$ \\
\hline $\begin{array}{l}\text { Escalated } \\
\text { Project Costs } \\
\text { for Year }\end{array}$ & $\$ 621,552$ & $\$ 639,270$ & $\$ 486,658$ & $\$ 602,129$ & $\$ 575,708$ \\
\hline $\begin{array}{l}\text { Total Escalated } \\
\text { Project Cost }\end{array}$ & $\$ 621,552$ & $\$ 1,260,822$ & $\$ 1,747,480$ & $\$ 2,349,609$ & $\$ 2,925,317$ \\
\hline
\end{tabular}


TABLE 14-2. FUEL ASSEMBLIES REMOVAL FROM T PLANT COST ESTIMATE

\begin{tabular}{|c|c|c|c|c|c|c|c|c|}
\hline PROJECT ACTIVITIES & $\begin{array}{c}\text { Duration } \\
\text { (Days) }\end{array}$ & FTE & $\begin{array}{c}\text { Trade } \\
\text { Indicator }\end{array}$ & Labor & Material & $\begin{array}{c}\text { Nomina! } \\
\text { Cost } \\
\text { Estimate }\end{array}$ & $\begin{array}{c}\text { Contingency } \\
\text { Variation }\end{array}$ & $\begin{array}{l}\text { Estimated Cost } \\
\text { Inclusive of } \\
\text { Contingency }\end{array}$ \\
\hline & & & & & & & & . \\
\hline PROJECT DOCUMENTATION & & 0.0 & & $\$ 0$ & $\$ 0$ & $\$ 30,000$ & & $\$ 38,000$ \\
\hline SAFETY BASIS DOCUMENTATION & & 0.0 & & $\$ 0$ & $\$ 0$ & $\$ 110,000$ & & $\$ 165,000$ \\
\hline & & & & & & & & \\
\hline ENVIRONMENTAL COMPLIANCE & & 0.0 & & $\$ 0$ & $\$ 0$ & $\$ 2,000$ & & $\$ 2,200$ \\
\hline PREP. OF OPERATIONAL DOCUMENTS & & 4.0 & & $\$ 109,054$ & $\$ 3,000$ & $\$ 112,054$ & & $\$ 134,465$ \\
\hline & & & & & & & & \\
\hline FUEL ASSEMBLY CHARACTERIZATION & & 0.0 & & $\$ 0$ & $\$ 0$ & $\$ 100,000$ & & $\$ 120,000$ \\
\hline NEW EQUIPMENT & & 4.0 & & $\$ 32,451$ & $\$ 21,000$ & $\$ 249,451$ & & $\$ 339,019$ \\
\hline & & & & & & & & \\
\hline START-UP ACTIVITIES & & 52.0 & & $\$ 459,503$ & $\$ 24,240$ & $\$ 473,743$ & & $\$ 531,025$ \\
\hline TRANSPORT ROUTEIEQUIPMENT & & 0.0 & & $\$ 0$ & $\$ 382,400$ & $\$ 382,400$ & & $\$ 473,880$ \\
\hline SNF REMOVAL ACTIVITIES & & 14.0 & & $\$ 528,122$ & $\$ 47,600$ & $\$ 575,722$ & & $\$ 690,866$ \\
\hline & & & & & & & & \\
\hline DECOMMISSIONING ACTIVITIES & & 19.0 & & $\$ 47,948$ & $\$ 5,040$ & $\$ 120,988$ & & $\$ 143,578$ \\
\hline & & & & & & & & \\
\hline TOTALS & & 93.0 & & $\$ 1,177,078$ & $\$ 483,280$ & $\$ 2,156,358$ & & $\$ 2,638,033$ \\
\hline TOTAL NOMINAL COST & & & & & & $\$ 2,156,358$ & & \\
\hline TOTAL HIGH END COST & & & & & & & $(+) 22 \%$ & $\$ 2,638,033$ \\
\hline
\end{tabular}

TOTAL ESTIMATED COST IS ASSUMED TO BE THE INDICATED HIGH END COST. THIS IS THE NOMINAL COST PLUS AN OVERALL 22\% CONTINGENCY ALLOWANCE FOR PROJECT UNCERTAINTIES. THE CONTINGENCY ALLOWANCE IS A WEIGHTED AVERAGE OF EACH ITEMS CONTINGENCY VARIATION.

NOTES:

- Fully Burdened Labor Rates in FY96 Dollars

Exempt - $\$ 52.43$

Bargaining Unit - $\$ 48.29$

- Dollars have NOT been escalated for outyears. 
TABLE 14-2. FUEL ASSEMBLIES REMOVAL FROM T PLANT

COST ESTIMATE

\begin{tabular}{|c|c|c|c|c|c|c|c|c|}
\hline PROJECT ACTIVITIES & $\begin{array}{c}\text { Duration } \\
\text { (Days) }\end{array}$ & FTE & $\begin{array}{c}\text { Trade } \\
\text { Indicator }\end{array}$ & Labor & Material & $\begin{array}{c}\text { Nominal } \\
\text { Cost } \\
\text { Estimate }\end{array}$ & $\begin{array}{l}\text { Contingency } \\
\text { Variation }\end{array}$ & $\begin{array}{l}\text { Estimated Cost } \\
\text { Inclusive of } \\
\text { Contingency }\end{array}$ \\
\hline & & & & & & & & . \\
\hline PROJECT DOCUMENTATION & & 0.0 & & $\$ 0$ & $\$ 0$ & $\$ 30,000$ & & $\$ 38,000$ \\
\hline \multirow{2}{*}{\multicolumn{9}{|c|}{ Issue Project Task Authorization }} \\
\hline & & & & & & & & \\
\hline \multicolumn{9}{|l|}{ Deliverabie: Project Task Authorization } \\
\hline \multicolumn{9}{|l|}{ Assumptions: Activities undefined at this time. } \\
\hline & & & & & & & & \\
\hline & & & & & & & & \\
\hline Produce Project QA Plan & & 0.0 & & $\$ 0$ & $\$ 0$ & $\$ 10,000$ & $+10 \% / \cdot 10 \%$ & $\$ 11,000$ \\
\hline \multirow{2}{*}{\multicolumn{9}{|c|}{ Deliverable: Project QA Plan }} \\
\hline & & & & & & & & \\
\hline \multicolumn{9}{|l|}{ Assumptions: See Section 8.9} \\
\hline \multicolumn{9}{|l|}{ Basis of Estimate: Discussions with off-site } \\
\hline \multicolumn{9}{|l|}{ contractor. } \\
\hline & & & & & & & & \\
\hline & & & & & & & & \\
\hline Fuel Assembly Characterization Report & & 0.0 & & so & so & $\$ 10,000$ & $+ 5 0 \% \longdiv { 1 - 1 0 \% }$ & $\$ 15,000$ \\
\hline & & & & & & & & \\
\hline \multicolumn{9}{|l|}{ Deliverable: Fuel Assembly Characterization Report } \\
\hline \multicolumn{9}{|l|}{ Assumptions: See Section 6.0} \\
\hline \multicolumn{9}{|l|}{ Basis of Estimate: Preliminary Assessment } \\
\hline & & & & & & & & \\
\hline Produce Fuel Assembly Technical Data Package & & 0.0 & & $\$ 0$ & so & $\$ 10,000$ & $+20 \%,-20 \%$ & $\$ 12.000$ \\
\hline & & & & & & & & \\
\hline \multicolumn{9}{|l|}{ Deliverable: Fuel Assembly Dala Package } \\
\hline \multicolumn{9}{|l|}{ Assumptions: See Section 6.8} \\
\hline \multicolumn{9}{|l|}{ Basis of Estimate: Preliminary Assessment } \\
\hline & & & & & & & & \\
\hline & & & & & & & & \\
\hline
\end{tabular}




\begin{tabular}{|c|c|c|c|c|c|c|c|c|}
\hline PROJECT ACTIVITIES & $\begin{array}{c}\text { Duration } \\
\text { (Days) }\end{array}$ & FTE & $\begin{array}{c}\text { Trade } \\
\text { Indicator }\end{array}$ & Labor & Material & $\begin{array}{c}\text { Nominal } \\
\text { Cost } \\
\text { Estimate }\end{array}$ & $\begin{array}{c}\text { Contingency } \\
\text { Variation }\end{array}$ & $\begin{array}{l}\text { Estimated Cost } \\
\text { Inclusive of } \\
\text { Contingency }\end{array}$ \\
\hline & & & & & & & & \\
\hline \multirow[t]{2}{*}{ SAFETY BASIS DOCUMENTATION } & & 0.0 & & $\$ 0$ & $\$ 0$ & $\$ 110,000$ & & $\$ 165,000$ \\
\hline & & & & & & & & \\
\hline \multirow[t]{2}{*}{ T Plant ISB } & & 0.0 & & $\$ 0$ & $\$ 0$ & $\$ 110,000$ & $+50 \% /-10 \%$ & $\$ 165,000$ \\
\hline & & & & & & & & \\
\hline \multicolumn{9}{|l|}{ Deliverable: T Plant ISB Addendurn } \\
\hline \multicolumn{9}{|l|}{ Assumptions: See Section 9.3.1 } \\
\hline \multicolumn{9}{|l|}{ Basis of Estimate: Discussions with off-site } \\
\hline \multicolumn{9}{|l|}{ contractor } \\
\hline \multicolumn{9}{|l|}{ Contingency Range depicts uncertainty of } \\
\hline \multicolumn{9}{|l|}{ work definition. } \\
\hline & & & & & & & & \\
\hline & & & & & & & & \\
\hline \multicolumn{9}{|l|}{ MCO Cask SARP Addendum } \\
\hline & & & & & & & & \\
\hline \multicolumn{9}{|l|}{ Deliverable: MCO Cask SARP Addendum } \\
\hline \multicolumn{9}{|l|}{ Assumptions: See Section 9.3 .2} \\
\hline \multicolumn{9}{|l|}{ Basis of Estimate: Will be provided by SNFP. } \\
\hline & & & & & & & & \\
\hline & & & & & & & & \\
\hline \multicolumn{9}{|l|}{ CSB SAR Addendum } \\
\hline & & & & & & & & \\
\hline \multicolumn{9}{|l|}{ Deliverable: CSB SAR } \\
\hline \multicolumn{9}{|l|}{ Assumptions: See Section 9.3 .3} \\
\hline \multicolumn{9}{|l|}{ Basis of Estimale: Will be provided by SNFP. } \\
\hline & & & & & & & & \\
\hline & & & & & & & & \\
\hline \multicolumn{9}{|l|}{ Criticality Evaluation } \\
\hline & & & & & & & & \\
\hline \multicolumn{9}{|l|}{ Deliverable: Criticabity Evaluation } \\
\hline \multicolumn{9}{|l|}{ Assumptions: See Section 93.1} \\
\hline \multicolumn{9}{|l|}{ Basis of Estimale: Included in ISB Addendum } \\
\hline & & & & & & & & \\
\hline & & & & & & & & \\
\hline
\end{tabular}


TABLE 14-2. FUEL ASSEMBLIES REMOVAL FROM T PLANT

COST ESTIMATE

\begin{tabular}{|c|c|c|c|c|c|c|c|c|}
\hline PROJECT ACTIVITIES & $\begin{array}{c}\text { Duration } \\
\text { (Days) }\end{array}$ & FTE & $\begin{array}{c}\text { Trade } \\
\text { Indicator }\end{array}$ & Labor & Material & $\begin{array}{c}\text { Nominal } \\
\text { Cost } \\
\text { Estimate }\end{array}$ & $\begin{array}{c}\text { Contingency } \\
\text { Variation }\end{array}$ & $\begin{array}{l}\text { Estimated Cost } \\
\text { Inclusive of } \\
\text { Contingency }\end{array}$ \\
\hline & & & & & & & & \\
\hline \multicolumn{9}{|l|}{ ALARA Plan } \\
\hline & & & & & & & & \\
\hline \multicolumn{9}{|l|}{ Detiverable: ALARA Plan } \\
\hline \multicolumn{9}{|l|}{ Assumptions: See Section 9.0} \\
\hline \multicolumn{9}{|l|}{ Basis of Estimate: Included in ISB Addendum } \\
\hline & & & & & & & & \\
\hline \multicolumn{8}{|l|}{ Preliminary Hazards Analysis } & \\
\hline & & & & & & & & \\
\hline \multicolumn{9}{|l|}{ Deliverable: Preliminary Hazards Analysis } \\
\hline \multicolumn{9}{|l|}{ Assumptions: See Section 9.3 .1} \\
\hline \multicolumn{9}{|l|}{ Basis of Estimate: Included in ISB Addendum } \\
\hline & & & & & & & & \\
\hline \multirow[t]{3}{*}{ ENVIRONMENTAL COMPLIANCE } & & 0.0 & & $\$ 0$ & $\$ 0$ & $\$ 2,000$ & & $\$ 2,200$ \\
\hline & & & & & & & & \\
\hline & & & & & & & & \\
\hline \multicolumn{9}{|l|}{ Environmental Assessment } \\
\hline \multicolumn{9}{|l|}{ Deliverable: Environmental Assessment } \\
\hline \multicolumn{9}{|l|}{ Assumptions: See Section 10.1} \\
\hline \multicolumn{9}{|l|}{ Basis of Estimate: Will be provided by SNFP. } \\
\hline & & & & & & & & \\
\hline & & & & & & & & \\
\hline \multicolumn{9}{|l|}{ CSB Notice of Construction } \\
\hline & & & & & & & & \\
\hline \multicolumn{9}{|l|}{ Deliverable: CSB Notice of Construction } \\
\hline \multicolumn{9}{|l|}{ Assumptions: See Section 1022} \\
\hline \multicolumn{9}{|l|}{ Basis of Estimale: Will be provided by SNFP. } \\
\hline & & & & & & & & \\
\hline & & & & & & & & \\
\hline
\end{tabular}


TABLE 14-2. FUEL ASSEMBLIES REMOVAL FROM T PLANT COST ESTIMATE

\begin{tabular}{|c|c|c|c|c|c|c|c|c|}
\hline PROJECT ACTIVITIES & $\begin{array}{c}\text { Duration } \\
\text { (Days) }\end{array}$ & FTE & $\begin{array}{c}\text { Trade } \\
\text { Indicator }\end{array}$ & Labor & Material & $\begin{array}{c}\text { Nominal } \\
\text { Cost } \\
\text { Estimate }\end{array}$ & $\begin{array}{c}\text { Contingency } \\
\text { Variation }\end{array}$ & $\begin{array}{l}\text { Estimated Cost } \\
\text { Inclusive of } \\
\text { Contingency }\end{array}$ \\
\hline & & & & & & & & $\therefore$ \\
\hline Cultural Resources Review & & 0.0 & & \$o & so & $\$ 2,000$ & $+10 \% /-10 \%$ & $\$ 2,200$ \\
\hline \multicolumn{9}{|l|}{ Deliverable: Cultural Resources Review } \\
\hline \multicolumn{9}{|l|}{ Assumptions: See Section 10.2 .3} \\
\hline \multicolumn{9}{|l|}{ Basis of Estimate: Not roquired. No change } \\
\hline \multicolumn{9}{|l|}{ to building structure anticipated. } \\
\hline & & & & & & & & \\
\hline \multirow{2}{*}{\multicolumn{9}{|c|}{ PREP. OF OPERATIONAL DOCUMENTS }} \\
\hline & & 4.0 & & $\$ 109,054$ & $\$ 3,000$ & $\$ 112,054$ & & $\$ 134,465$ \\
\hline I Plant Training Manuals & 90 & 1.0 & Training inst & $\$ 37,750$ & $\$ 800$ & $\$ 38,550$ & $+20 \% / \cdot 20 \%$ & $\$ 46,260$ \\
\hline \multicolumn{9}{|l|}{ Deliverable: T Plant Training Manuals } \\
\hline \multicolumn{9}{|l|}{ Assumplions: All process workers and crane } \\
\hline \multicolumn{9}{|l|}{ operators will require certification training. } \\
\hline \multicolumn{9}{|l|}{ Basis of Estimate: Discussions with the WHC } \\
\hline \multicolumn{9}{|l|}{ Training Department. } \\
\hline & & & & & & & & \\
\hline T Plant Operational Procedures & 130 & 1.0 & Proc Writer & $\$ 54,527$ & $\$ 600$ & $\$ 55,127$ & $+20 \% \quad /-20 \%$ & $\$ 66,153$ \\
\hline \multicolumn{9}{|l|}{ Deliverable: T Plant Operational Procedures } \\
\hline \multicolumn{9}{|l|}{ Assumptions: New operational procedures are } \\
\hline \multicolumn{9}{|l|}{ required for PWR-2 removal process from T Plant. } \\
\hline \multicolumn{9}{|l|}{ Basis of Estimate: Discussions with T Plant } \\
\hline \multicolumn{9}{|l|}{ Operations Management. } \\
\hline & & & & & & & & \\
\hline T Plant Health Physics Procedures & 20 & 1.0 & Proc. Writer & $\$ 8,389$ & $\$ 800$ & $\$ 9,189$ & $+20 \% \quad / \quad-20 \%$ & $\$ 11,027$ \\
\hline & & & & & & & & \\
\hline Deliverable: Health Physics Procedures & & & & & & & & \\
\hline Assumptions: Health Physics procedures will & & & & & & & & \\
\hline need to be modified to accommodate PWR - 2 removal & & & & & & & & \\
\hline Basis of Estimate: Discussions with T Plant & & & & & & & & \\
\hline Health Physics Management. & & & & & & & & \\
\hline
\end{tabular}


TABLE 14-2. FUEL ASSEMBLIES REMOVAL FROM T PLANT

COST ESTIMATE

\begin{tabular}{|c|c|c|c|c|c|c|c|c|}
\hline PROJECT ACTIVITIES & $\begin{array}{c}\text { Duration } \\
\text { (Days) }\end{array}$ & FTE & $\begin{array}{c}\text { Trade } \\
\text { Indicator }\end{array}$ & Labor & Material & $\begin{array}{l}\text { Nominal } \\
\text { Cost } \\
\text { Estimate }\end{array}$ & $\begin{array}{l}\text { Contingency } \\
\text { Variation }\end{array}$ & $\begin{array}{l}\text { Estimated Cost } \\
\text { Inclusive of } \\
\text { Contingency }\end{array}$ \\
\hline & & & & & & & & $\therefore$ \\
\hline T Plant Maintenance Manuals/Procedures & 20 & 1.0 & Proc Writer & $\$ 8,389$ & $\$ 800$ & $\$ 9,189$ & $+20 \% /-20 \%$ & $\$ 11,027$ \\
\hline \multicolumn{9}{|l|}{ Deliverable: Maintenance Manual } \\
\hline \multicolumn{9}{|l|}{ Assumptions: it is assumed that Maintenance } \\
\hline \multicolumn{9}{|l|}{ Manuals are produced by the Design Authorities. } \\
\hline \multicolumn{9}{|l|}{ Maintenance procedures are required for new } \\
\hline \multicolumn{9}{|l|}{ equipment. } \\
\hline \multicolumn{9}{|l|}{ Basis of Estimate: Discussions with I Plant } \\
\hline \multicolumn{9}{|l|}{ Maintenance Department. } \\
\hline & & & & & & & & \\
\hline & & & & & & & & \\
\hline \multicolumn{9}{|l|}{ Transportation Document (Assumed Existing) } \\
\hline & & & & & & & & \\
\hline \multicolumn{9}{|l|}{ Deliverable: Transportation Documentation } \\
\hline \multicolumn{9}{|l|}{ Assumptions: This documentation is assumed } \\
\hline \multicolumn{9}{|l|}{ to be existing. } \\
\hline & & & & & & & & \\
\hline \multirow{2}{*}{ FUEL ASSEMBLY CHARACTERIZATION } & & & & & & $\$ 100,000$ & & $\$ 120,000$ \\
\hline & & & & & & & & \\
\hline \multicolumn{9}{|l|}{ Fuel Assembly Characterization } \\
\hline . & & & & & & & & \\
\hline Deliverable: Assembly Chacterization & & & & & & $\$ 100,000$ & $+20 \% /-20 \%$ & $\$ 120,000$ \\
\hline \multicolumn{9}{|l|}{ Assumptions: See Section 6.0} \\
\hline \multicolumn{9}{|l|}{ Basis of Estimate: Preliminary Assessment } \\
\hline & & & & & & & & \\
\hline NEW EQUIPMENT & & 4.0 & & $\$ 32,451$ & $\$ 21,000$ & $\$ 249,451$ & & $\$ 339,019$ \\
\hline Primary Grapples & & 0.0 & & $\$ 0$ & $\$ 0$ & $\$ 125,000$ & & $\$ 187,500$ \\
\hline DESIGN & & & & & & $\$ 50,000$ & $+50 \% /-10 \%$ & $\$ 75,000$ \\
\hline CONSTRUCTION & & & & & & $\$ 75,000$ & $+50 \% /-50 \%$ & $\$ 112,500$ \\
\hline Deliverable. Primary Grapples (5) & & & & & & & & \\
\hline Assumptions: See Section 8.1.4 & & & & & & & & \\
\hline Basis of Estimate: Discussions with off-site & & & & & & & & \\
\hline
\end{tabular}


TABLE 14-2. FUEL ASSEMBLIES REMOVAL FROM T PLANT

COST ESTIMATE

\begin{tabular}{|c|c|c|c|c|c|c|c|c|}
\hline PROJECT ACTIVITIES & $\begin{array}{c}\text { Duration } \\
\text { (Days) }\end{array}$ & FTE & $\begin{array}{c}\text { Trade } \\
\text { Indicator }\end{array}$ & Labor & Material & $\begin{array}{c}\text { Nominal } \\
\text { Cost } \\
\text { Estimate }\end{array}$ & $\begin{array}{c}\text { Contingency } \\
\text { Variation }\end{array}$ & $\begin{array}{l}\text { Estimated Cost } \\
\text { Inclusive of } \\
\text { Contingency }\end{array}$ \\
\hline & & & & & & & & $\therefore$ \\
\hline \multicolumn{9}{|l|}{ design consultants. } \\
\hline \multicolumn{9}{|l|}{ Contingency Range reflects uniqueness } \\
\hline \multicolumn{9}{|l|}{ complexity/small number of units. } \\
\hline & & & & & & & & \\
\hline & & & & & & & & \\
\hline Secondary Grapples & & 0.0 & & so & $\$ 0$ & $\$ 50,000$ & & $\$ 65,000$ \\
\hline DESIGN & & 0.0 & & $\$ 0$ & $\$ 0$ & $\$ 25,000$ & $+30 \% /-10 \%$ & $\$ 32,500$ \\
\hline CONSTRUCIION & & 0.0 & & $\$ 0$ & so & $\$ 25,000$ & $+30 \% /-10 \%$ & $\$ 32,500$ \\
\hline \multicolumn{9}{|l|}{ Defiverable: Secondary Grapples (5) } \\
\hline \multicolumn{9}{|l|}{ Assumptions: See Section 8.1 .4} \\
\hline \multicolumn{9}{|l|}{ Basis of Estimate: Discussions with off-site } \\
\hline \multicolumn{9}{|l|}{ design consultants. } \\
\hline \multicolumn{9}{|l|}{ Contingency Range reflects uniqueness/ } \\
\hline \multicolumn{9}{|l|}{ complexity/small number of units. } \\
\hline & & & & & & & & \\
\hline & & & & & & & & \\
\hline \multirow[t]{2}{*}{ 3-Ton Hoist } & & 4.0 & & $\$ 32.451$ & $\$ 20,000$ & $\$ 52,451$ & $+15 \%,-10 \%$ & $\$ 60,319$ \\
\hline & 21 & 2.0 & Electrician & $\$ 16,225$ & & & & \\
\hline Deliverable: 3 -Ton Hoist w/load limiter and readout. & 21 & 2.0 & Riggers & $\$ 16.225$ & & & & \\
\hline \multicolumn{9}{|l|}{ Labor to fit to crane bridge. } \\
\hline \multicolumn{9}{|l|}{ Assumptions: See Section 8.1 .3 .3} \\
\hline \multicolumn{9}{|l|}{ Basis of Estimate: Professional Judgment } \\
\hline \multicolumn{9}{|l|}{ design consultants. } \\
\hline & & & & & & & & \\
\hline & & & & & & & & \\
\hline \multirow[t]{2}{*}{ Cask Lid Grapple } & & 00 & & $\$ 0$ & $\$ 1,000$ & $\$ 1,000$ & $+10 \% / 10 \%$ & $\$ 1,100$ \\
\hline & & & & & & & & \\
\hline \multicolumn{9}{|l|}{ Deliverable: Cask Lid Grapple } \\
\hline \multicolumn{9}{|l|}{ Assumptions: See Section 8.1.4 } \\
\hline \multicolumn{9}{|l|}{ Basis of Estimate: Standard Rigging Equipment } \\
\hline & & & & & & & & \\
\hline & & & & & & & & \\
\hline
\end{tabular}


TABLE 14-2. FUEL ASSEMBLIES REMOVAL FROM T PLANT COST ESTIMATE

\begin{tabular}{|c|c|c|c|c|c|c|c|c|}
\hline PROJECT ACTIVITIES & $\begin{array}{c}\text { Duration } \\
\text { (Days) }\end{array}$ & FTE & $\begin{array}{c}\text { Trade } \\
\text { Indicator }\end{array}$ & Labor & Material & $\begin{array}{c}\text { Nominal } \\
\text { Cost } \\
\text { Estimate }\end{array}$ & $\begin{array}{c}\text { Contingency } \\
\text { Variation }\end{array}$ & $\begin{array}{l}\text { Estimated Cost } \\
\text { Inclusive of } \\
\text { Contingency }\end{array}$ \\
\hline & & & & & & & & $\cdot$ \\
\hline Grapple Stand & & 0.0 & & $\$ 0$ & so & $\$ 10,000$ & $420 \%,-20 \%$ & $\$ 12,000$ \\
\hline DESIGN & & 0.0 & & $\$ 0$ & $\$ 0$ & $\$ 5,000$ & & \\
\hline CONSTRUCTION & & 0.0 & & $\$ 0$ & so & $\$ 5,000$ & & \\
\hline \multicolumn{9}{|l|}{ Deliverable: Grapple Stand } \\
\hline \multicolumn{9}{|l|}{ Assumptions: See Section 8.1 .4} \\
\hline \multicolumn{9}{|l|}{ Basis of Estimate: Discussions with otf-site } \\
\hline \multicolumn{9}{|l|}{ design contractor. } \\
\hline & & & & & & & & \\
\hline & & & & & & & & \\
\hline T Plant Canister Lid Grapple & & 0.0 & & $\$ 0$ & $\$ 0$ & $\$ 1,000$ & $+10 \% /-10 \%$ & $\$ 1,100$ \\
\hline DESIGN & & 0.0 & & $\$ 0$ & so & $\$ 500$ & & \\
\hline CONSTRUCTION & & 0.0 & & $\$ 0$ & $\$ 0$ & $\$ 500$ & & \\
\hline \multicolumn{9}{|l|}{ Deliverable: MCO Lid Grapple } \\
\hline \multicolumn{9}{|l|}{ Assumptions: See Section 8.1.4 } \\
\hline \multicolumn{9}{|l|}{ Basis of Estimate: Discussions with $\mathrm{K}$ Basin } \\
\hline \multicolumn{9}{|l|}{ Design Authority. } \\
\hline & & & & & & & & \\
\hline \multicolumn{9}{|l|}{ T Plant Canisler (MCO) } \\
\hline & & & & & & & & \\
\hline \multicolumn{9}{|l|}{ Deliverable: MCO Container $\&$ Shield Plug } \\
\hline \multicolumn{9}{|l|}{ Assumptions: See Section $\mathbf{8 . 2}$} \\
\hline \multicolumn{9}{|l|}{ Basis of Estimate: Will be provided by SNFP. } \\
\hline & & & & & & & & \\
\hline \multicolumn{9}{|l|}{ Vacuum Drying Equipment } \\
\hline & & & & & & & & \\
\hline \multicolumn{9}{|l|}{ Deliverable: Vacuum Drying Equipment } \\
\hline \multicolumn{9}{|l|}{ Assumptions: See Section 8.3} \\
\hline \multicolumn{9}{|l|}{ Basis of Estimate: Will be provided by SNFP. } \\
\hline & & & & & & & & \\
\hline & & & & & & & & \\
\hline
\end{tabular}


TABLE 14-2. FUEL ASSEMBLIES REMOVAL FROM T PLANT

COST ESTIMATE

\begin{tabular}{|c|c|c|c|c|c|c|c|c|}
\hline PROJECT ACTIVITIES & $\begin{array}{c}\text { Duration } \\
\text { (Days) }\end{array}$ & FTE & $\begin{array}{c}\text { Trade } \\
\text { Indicator }\end{array}$ & Labor & Material & $\begin{array}{c}\text { Nominal } \\
\text { Cost } \\
\text { Estimate }\end{array}$ & $\begin{array}{c}\text { Contingency } \\
\text { Variation }\end{array}$ & $\begin{array}{l}\text { Estimated Cost } \\
\text { Inclusive of } \\
\text { Contingency }\end{array}$ \\
\hline & & & & & & & & $\therefore$ \\
\hline T Plant Canister Loading Guide & & 0.0 & & $\$ 0$ & $\$ 0$ & $\$ 10,000$ & $+20 \% / 20 \%$ & $\$ 12,000$ \\
\hline DESIGN & & 0.0 & & $\$ 0$ & $\$ 0$ & $\$ 5,000$ & & \\
\hline CONSTRUCTION & & 0.0 & & so & $\$ 0$ & $\$ 5,000$ & & \\
\hline \multicolumn{9}{|l|}{ Deliverable: MCO Loading Guide } \\
\hline \multicolumn{9}{|l|}{ Assumptions: See Section 8.2} \\
\hline \multicolumn{9}{|l|}{ Basis of Estimate: Discussions with off-site } \\
\hline \multicolumn{9}{|l|}{ design contractor. } \\
\hline & & & & & & & & \\
\hline & & & & & & & & \\
\hline T PLANT START-UP ACTIVITIES & & 52.0 & & $\$ 459,503$ & $\$ 24,240$ & $\$ 473,743$ & & $\$ 531,025$ \\
\hline Start-up Dooumentation (ATP) & 90 & 1 & Test Engineer & $\$ 37,750$ & $\$ 800$ & $\$ 38,550$ & $+20 \% / \quad .20 \%$ & $\$ 46,260$ \\
\hline & & & & & & & & \\
\hline \multicolumn{9}{|l|}{ Deliverable: Start-up Documents } \\
\hline \multicolumn{9}{|l|}{ Assumptions: Start-up documentation will be } \\
\hline \multicolumn{9}{|l|}{ required to perform start-up testing on the } \\
\hline \multicolumn{9}{|l|}{ recovery process. } \\
\hline \multicolumn{9}{|l|}{ Basis of Estimate: Discussions with T Plant } \\
\hline \multicolumn{9}{|l|}{ Management. } \\
\hline & & & & & & & & \\
\hline & & & & & & & & \\
\hline Manuf/Obt. Training Aids-(4) Simulated Fuel Assemblies & & 0 & & $\$ 0$ & $\$ 10,000$ & $\$ 10,000$ & $+20 \% \quad l-20 \%$ & $\$ 12,000$ \\
\hline & & & & & & & & \\
\hline \multicolumn{9}{|l|}{ Deliverable: 4 Simulated Fuel Assemblies } \\
\hline \multicolumn{9}{|l|}{ Assumptions: 4 Carbon Steel simulated fuel } \\
\hline \multicolumn{9}{|l|}{ assemblies will be required for training/start-up } \\
\hline \multicolumn{9}{|l|}{ activities. } \\
\hline \multicolumn{9}{|l|}{ Basis of Estimate: Discussions with off-site } \\
\hline \multicolumn{9}{|l|}{ contractor. } \\
\hline & & & & & & & & \\
\hline Stant-un testing (Non-Radioactive) & & & & & & & & \\
\hline Start-up testing (Non-Radioactive) & 30 & $\frac{5.0}{2}$ & Test Engineers & $\frac{\$ 62,916}{\$ 25,166}$ & $\$ 600$ & $\$ 63,516$ & $+10 \% /-10 \%$ & $\$ 69,868$ \\
\hline Deliverable: Start-up tests & 30 & 2.0 & Millwright & $\$ 25,166$ & & & & \\
\hline Assumptions: 2 Test Engineers, 2 Millwrights, and & 30 & 1.0 & Supervisor & $\$ 12,583$ & & & & \\
\hline
\end{tabular}




\begin{tabular}{|c|c|c|c|c|c|c|c|c|}
\hline & & & & 26028 & anpaups/ravueld & $\mathrm{I}$ & $\bar{g}$ & 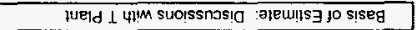 \\
\hline & & & & $160 \% \$$ & 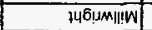 & $z$ & t & paunsse si Jalnpay \\
\hline & & & & ESt'SLS & 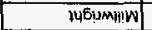 & 2 & 02 & 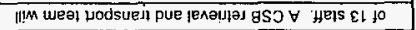 \\
\hline & & & & Zह9'8हs & SIOPEIAdO I & $\mathrm{s}$ & oz & \\
\hline \multirow[t]{6}{*}{2916118} & $\% 01-7 \% 01+$ & $\varepsilon \varepsilon \varepsilon^{\prime} 801 \$$ & $0+0$ 'z\$ & $86 e^{\prime} 901 \$$ & & $9 \mathrm{gt}$ & & 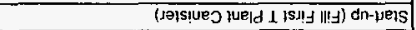 \\
\hline & & & & & & & & \\
\hline & & & & & & & & 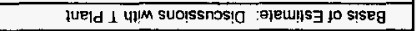 \\
\hline & & & & & & & & 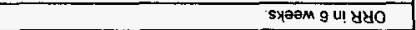 \\
\hline & & & & & & & & 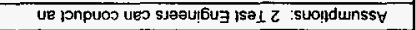 \\
\hline & & & & & & & & 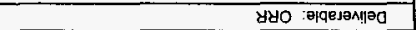 \\
\hline & & & & & & & & \\
\hline \multirow[t]{8}{*}{$6 \varepsilon 9 \cdot 095$} & $\% 0 z-1 \% 0 z+$ & \begin{tabular}{|c|c|}
$E S$ OS\$ \\
\end{tabular} & 0025 & 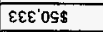 & 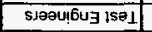 & $t$ & $0 \varepsilon$ & 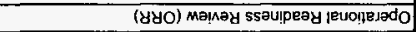 \\
\hline & & & & & & & & \\
\hline & & & & & & & & 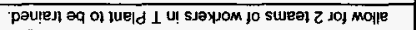 \\
\hline & & & & & & & & 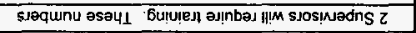 \\
\hline & & & & & & & & 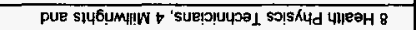 \\
\hline & & & & & & & & 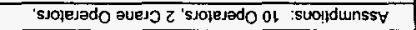 \\
\hline & & & & $8 \angle L$ '9IS & S.osinedns & $0 z$ & oz & 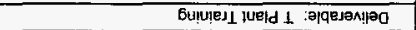 \\
\hline & & & & DEP'SBIS & HEIS & $\nabla z$ & oz & \\
\hline \multirow[t]{7}{*}{$z 60^{\prime} \varepsilon z z \$$} & $\% 01 \cdot, \% 01+$ & IL8'ZOZs & 0095 & LLZ'ZOZ\$ & Heis & 0.92 & & Eupuete \\
\hline & & & & & & & & \\
\hline & & & & & & & & \\
\hline & & & & & & & & 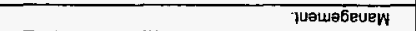 \\
\hline & & & & & & & & 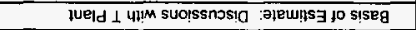 \\
\hline & & & & & & & & JOS!Nadn $!$ \\
\hline & & & & & & & & \\
\hline 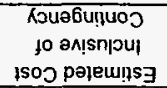 & 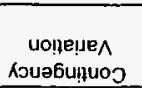 & $\begin{array}{l}\text { әleunis } \\
\text { Isoj } \\
\text { ןeutwon }\end{array}$ & |в!!ejeW & doqe 7 & $\begin{array}{l}\text { נopesppul } \\
\text { әpes। }\end{array}$ & $\exists \perp \mathrm{J}$ & $\begin{array}{c}\text { (skeg) } \\
\text { uomejeng }\end{array}$ & 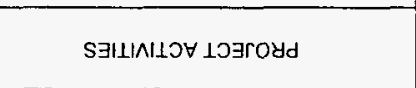 \\
\hline
\end{tabular}

IIVWILS $\exists \perp S O J$

IN 
TABLE 14-2. FUEL ASSEMBLIES REMOVAL FROM T PLANT

COST ESTIMATE

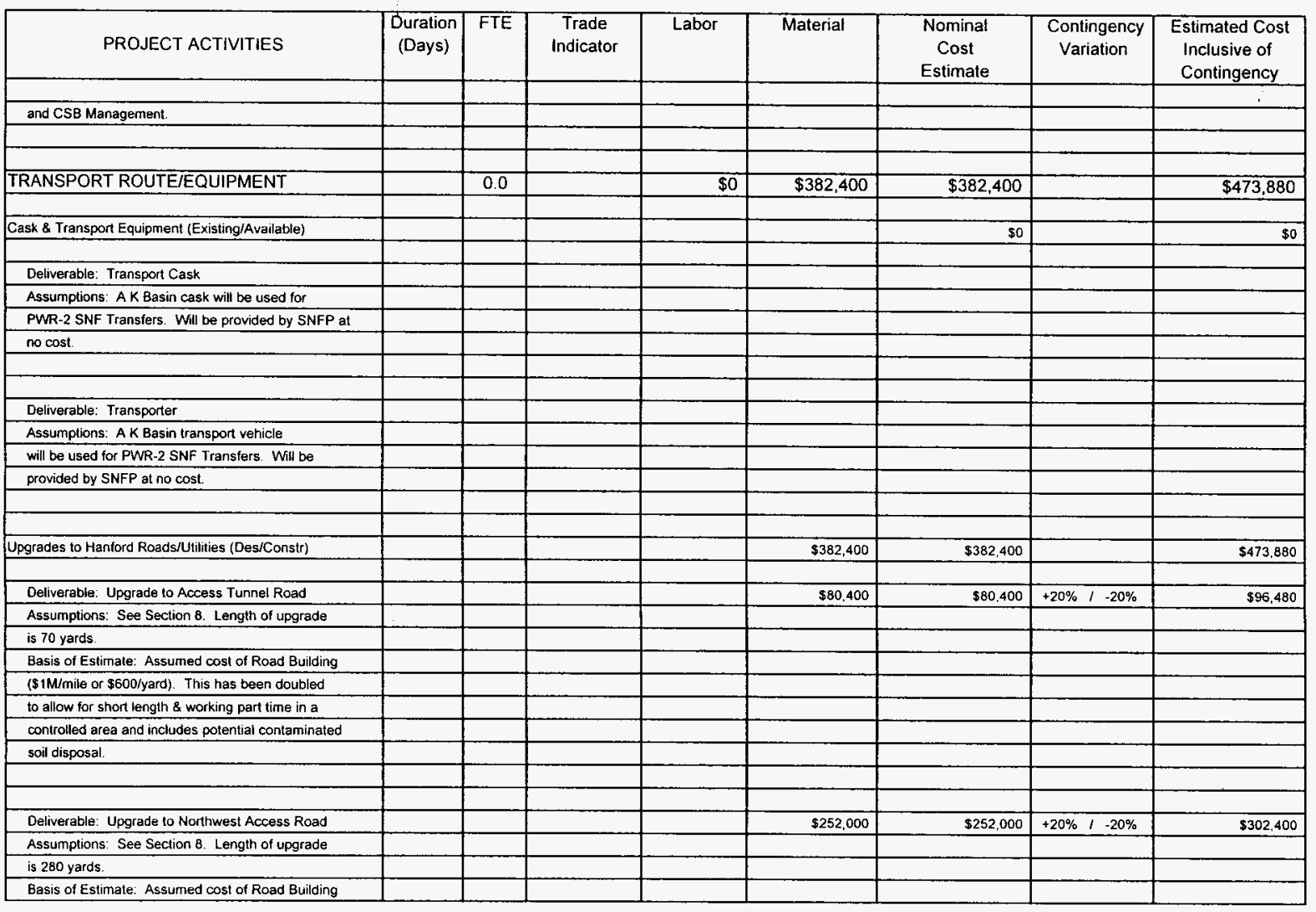


TABLE 14-2. FUEL ASSEMBLIES REMOVAL FROM T PLANT COST ESTIMATE

\begin{tabular}{|c|c|c|c|c|c|c|c|c|}
\hline PROJECT ACTIVITIES & $\begin{array}{c}\text { Duration } \\
\text { (Days) }\end{array}$ & FTE & $\begin{array}{c}\text { Trade } \\
\text { Indicator }\end{array}$ & Labor & Material & $\begin{array}{c}\text { Nominal } \\
\text { Cost } \\
\text { Estimate }\end{array}$ & $\begin{array}{c}\text { Contingency } \\
\text { Variation }\end{array}$ & $\begin{array}{l}\text { Estimated Cost } \\
\text { Inclusive of } \\
\text { Contingency }\end{array}$ \\
\hline & & & & & & & & $\because$ \\
\hline \multicolumn{9}{|l|}{ ( $\$ 1 \mathrm{M} / \mathrm{mile}$ or $\$ 600 /$ yard $)$. This has been increased } \\
\hline \multicolumn{9}{|l|}{ by $50 \%$ to allow for short length of road work } \\
\hline & & & & & & & & \\
\hline & & & & & & & & \\
\hline Deliverable: Upgrade to Road Utilities & & & & & $\$ 50.000$ & $\$ 50,000$ & $+50 \% / .50 \%$ & $\$ 75,000$ \\
\hline \multicolumn{9}{|l|}{ Assumptions: Road will not require strengthening } \\
\hline \multicolumn{9}{|l|}{ where water lines, etc. pass under the road. } \\
\hline \multicolumn{9}{|l|}{ A budget of $\$ 50,000$ is allowed for lifting any } \\
\hline \multicolumn{9}{|l|}{ telephone lines and power cables. (Potentially 25) } \\
\hline \multicolumn{9}{|l|}{ Basis of Estimate: Budget allowance only. } \\
\hline \multicolumn{9}{|l|}{ (Unable to measure cable heights) } \\
\hline & & & & & & & & \\
\hline & & & & & & & & \\
\hline \multirow[t]{2}{*}{ Railroad Upgrades (Assumed Nol Reqd) } & & & & & $\$ 0$ & $\$ 0$ & & $\$ 0$ \\
\hline & & & & & & & & \\
\hline \multicolumn{9}{|l|}{ Deliverable: Upgrade to Railroad Crossing Points } \\
\hline \multicolumn{9}{|l|}{ Assumptions: No upgrade required. } \\
\hline & & & & & & & & \\
\hline & & & & & & & & \\
\hline \multirow[t]{2}{*}{ Safety Equipment (Existing) } & & & & & $\$ 0$ & $\$ 0$ & & $\$ 0$ \\
\hline & & & & & & & & \\
\hline \multicolumn{9}{|l|}{ Deliverable: Transportation Safety Equipment } \\
\hline \multicolumn{9}{|l|}{ Assumptions: All required equipment is available } \\
\hline \multicolumn{9}{|l|}{ on site; firetruck, escort cars, warning flags, etc. } \\
\hline & & & & & & & & \\
\hline & & & & & & & & \\
\hline SNF REMOVAL ACTIVITIES & & 14.0 & & $\$ 528,122$ & $\$ 47,600$ & $\$ 575,722$ & & $\$ 690,866$ \\
\hline \multirow[t]{2}{*}{ Operations at T Plant } & & 14 & & $\$ 528,122$ & $\$ 47,600$ & $\$ 575,722$ & $+20 \% /-20 \%$ & $\$ 690,866$ \\
\hline & 119 & 5 & T Operators & $\$ 229,860$ & $\$ 47,600$ & & & \\
\hline Deliverable: I Plant Operations & $\$ 19$ & 4 & T HPTs & $\$ 183,888$ & & & & \\
\hline Assumptions: T Plant operations will require a team & 119 & 1 & T Crane Opt & $\$ 34,769$ & & & & \\
\hline of 13 staff to remove PWR-2 fuel assemblies. & 119 & 2 & Millwrights & $\$ 69,538$ & & & & \\
\hline $1 \mathrm{MCO}$ each 7 working days is assumed. & 119 & 1 & T Supervisor & $\$ 7,969$ & & & & \\
\hline One part-time Planner/Scheduler is assumed. & 5 & 1 & Planner/Schedule & $\$ 2,097$ & & & & \\
\hline
\end{tabular}


TABLE 14-2. FUEL ASSEMBLIES REMOVAL FROM T PLANT COST ESTIMATE

\begin{tabular}{|c|c|c|c|c|c|c|c|c|}
\hline PROJECT ACTIVITIES & $\begin{array}{c}\text { Duration } \\
\text { (Days) }\end{array}$ & FTE & $\begin{array}{c}\text { Trade } \\
\text { Indicator }\end{array}$ & Labor & Material & $\begin{array}{c}\text { Nominal } \\
\text { Cost } \\
\text { Estimate }\end{array}$ & $\begin{array}{c}\text { Contingency } \\
\text { Variation }\end{array}$ & $\begin{array}{c}\text { Estimated Cost } \\
\text { inclusive of } \\
\text { Contingency }\end{array}$ \\
\hline & & & & & & & & \\
\hline \multicolumn{9}{|l|}{ Transportation to and from CSB } \\
\hline \multicolumn{9}{|l|}{ Deliverable: Transportation } \\
\hline \multicolumn{9}{|l|}{ Assumptions: Transportation and packaging will } \\
\hline \multicolumn{9}{|l|}{ be provided by SNFP at no cost. } \\
\hline & & & & & & & & \\
\hline & & & & & & & & \\
\hline \multicolumn{9}{|l|}{ Operations at CSB } \\
\hline \multicolumn{9}{|l|}{ Deliverable: CSB Operations. } \\
\hline \multicolumn{9}{|l|}{ Packaging Supervisor } \\
\hline \multicolumn{9}{|l|}{ Assumptions: CSB personnel will be provided } \\
\hline \multicolumn{9}{|l|}{ by SNFP at no cost. } \\
\hline & & & & & & & & \\
\hline & & & & & & & & \\
\hline \multirow[t]{2}{*}{ DECOMMISSIONING ACTIVITIES } & & 19.0 & & $\$ 47,948$ & $\$ 5,040$ & $\$ 120,988$ & & $\$ 143,578$ \\
\hline & & & & & & & & \\
\hline Remove Pool Water from I Plant & & 10 & & $\$ 41,314$ & $\$ 3,600$ & $\$ 104,914$ & $+20 \% /-20 \%$ & $\$ 125,897$ \\
\hline Pump Equipment \& Instrumentation & & & & & & $\$ 10,000$ & & \\
\hline Road Tanker (Existing) & & & & & & $\$ 0$ & & \\
\hline Disposal Cost to 200E Area ETF & & & & & & $\$ 50,000$ & & \\
\hline Documentation (Existing) & & & & & & $\$ 0$ & & \\
\hline Deliverable: Remove and dispose of pool water. & 11 & 1 & Driver & $\$ 4,250$ & $\$ 3,600$ & & & \\
\hline Assumptions: 5000 gallon road tanker is used to & 11 & 2 & HPT & $\$ 8,499$ & & & & \\
\hline dispose of pool water and wash down. 11 trips & 11 & 2 & Operator & $\$ 8,499$ & & & & \\
\hline to ETF are assumed. 10 days to install equipment & 10 & 2 & Pipefitters & $\$ 7.726$ & & & & \\
\hline is assumed & 10 & 1 & Electrician & $\$ 3,863$ & & & & \\
\hline Basis of Estimate: Discussion with T Plant & 10 & 1 & Instr. Tech. & $\$ 3,863$ & & & & \\
\hline Management and ETF Management. & 11 & 1 & Supervisor & $\$ 4.614$ & & & & \\
\hline & & & & & & & & \\
\hline & & & & & & & & \\
\hline
\end{tabular}


TABLE 14-2. FUEL ASSEMBLIES REMOVAL FROM T PLANT COST ESTIMATE

\begin{tabular}{|c|c|c|c|c|c|c|c|c|}
\hline PROJECT ACTIVITIES & $\begin{array}{c}\text { Duration } \\
\text { (Days) }\end{array}$ & FTE & $\begin{array}{c}\text { Trade } \\
\text { Indicator }\end{array}$ & Labor & Material & $\begin{array}{c}\text { Nominal } \\
\text { Cost } \\
\text { Estimate }\end{array}$ & $\begin{array}{c}\text { Contingency } \\
\text { Variation }\end{array}$ & $\begin{array}{l}\text { Estimated Cost } \\
\text { Inclusive of } \\
\text { Contingency }\end{array}$ \\
\hline & & & & & & & & \\
\hline Remove Ion Exchange Column & & 9 & & $\$ 6,634$ & $\$ 1,440$ & $\$ 16.074$ & $+10 \%,-10 \%$ & $\$ 17.681$ \\
\hline Equipment (Existing) & & & & & & so & & \\
\hline Disposal Costs (\$17.50 ft3) & & & & & $\$ 760$ & $\$ 3,000$ & & \\
\hline Documentation (Existing) & & & & & & so & & \\
\hline Deliverable: Removal and disposal of lon Exchange & 2 & 2 & Operators & $\$ 1,545$ & $\$ 680$ & $\$ 5,000$ & & \\
\hline Column. & 2 & 3 & HPT & $\$ 2,318$ & & & & \\
\hline Assumptions: The lon Exchange Colurnn is & 2 & 2 & Pipefitter & $\$ 1,545$ & & & & \\
\hline disposed as Category 1 Low Level Waste. & 1 & 1 & Crane Operator & $\$ 386$ & & & & \\
\hline Column is fitted into a standard disposal box and & 2 & 1 & Supenvisor & $\$ 839$ & & & & \\
\hline \multicolumn{9}{|l|}{ all void space is filled with a non-compactable fill. } \\
\hline \multicolumn{9}{|l|}{ Basis of Estimate: Discussion with T Plant } \\
\hline \multicolumn{9}{|l|}{ Management. } \\
\hline & & & & & & & & \\
\hline & & & & & & & & \\
\hline TOTAL & & 93.0 & & $\$ 1,177,078$ & $\$ 483,280$ & $\$ 2,156,358$ & & $\$ 2,638,033$ \\
\hline
\end{tabular}


This page intentionally left blank. 


\subsection{REFERENCES}

10 CFR 71, 1994, Packaging and Transportation of Radioactive Materials.

$\mathrm{ACl}, 1989$, Code Requirements for Nuclear Safety Related Concrete Structures - ACl Manual of Concrete Practice 1989, Part 4, ACl 349-85, American Concrete Institute, Detroit, Michigan.

Atherton, R., Budd, W. A., 1983, Shippingport Operations During PWR Core 2 Depletion (April 1965 to February 1974), WAPD-335, Bettis Atomic Power Laboratory, West Mifflin, Pennsyivania.

Atherton, R., Kikta, E. J., Sherman, J., 1968, PWR Core 2 Reactor Design Description Report, WAPD-296, Bettis Atomic Power Laboratory, Pittsburgh, Pennsylvania.

Bergsman, K. H., 1994, Hanford Spent Fuel Inventory Baseline, WHC-SD-SNF-TI-001, Rev. O, Westinghouse Hanford Company, Richland, Washington.

Bradley, E. R., Bailey, W. J., Johnson A.B., Lowry, L. M., 1981, Examination of Zircaloy-Clad Spent Fuel After Extended Pool Storage. PNL-3921, Pacific Northwest Laboratory, Richland, Washington.

Clayton J. C., et al., 1993, End-of-life destructive Examinations Of Zircaloy Maximum Depletion Blanket Fuel Plates From The Shippingport PWR Core 2, WAPD-T-2978, Bettis Atomic Power Laboratory, West Mifflin, Pennsylvania.

DOE, 1987, Project Management System, DOE Order 4700.1, U.S. Department of Energy.

DOE, 1989, General Design Criteria, DOE 6430.1A, U.S. Department of Energy.

DOE, 1991, Unreviewed Safety Questions, DOE Order 5480.21, U.S. Department of Energy.

DOE, 1992a, Hazard Category and Accident Analysis Techniques for Compliance with DOE Order 5480.23, Nuclear Safety Analysis Reports, DOE-STD-1027-92,

U.S. Department of Energy.

DOE, 1992b, Safety Analysis Reports, DOE Order 5480.23, U.S. Department of Energy.

DOE, 1993a, Personnel Selection, Qualification, Training, and Staffing Requirements at DOE Reactor and Non-Reactor Facilities, DOE Order 5480.20A, U.S. Department of Energy.

DOE, 1993b, Planning and Conduct Of Operational Readiness Reviews, DOE-STD-3006-93, U.S. Department of Energy.

DOE, 1993c, Preparation for U.S. Department of Energy Nonreactor Nuclear Facility Safety Analysis Reports, DOE-STD-3009-93, U.S. Department of Energy. 
DOE, 1993d Radiation Protection of Public and the Environment, DOE Order 5400.5, U.S. Department of Energy.

DOE, 1993e, Start-up and Restart of Nuclear Facilities, DOE Order 5480.31, U.S. Department of Energy.

DOE, 1994, Control and Accountability of Nuclear Material, DOE Order 5633.3, U.S. Department of Energy.

DOE, 1995a, K Basins Spent Fuel Project - Regulatory Policy, Draft, U.S. Department of Energy.

DOE, 1995b, Packaging and Transportation Safety, DOE Order 460.1, U.S. Department of Energy.

DOE, 1995c, Department of Energy Programmatic Spent Nuc/ear Fuel Management and Idaho National Engineering Laboratory Environmental Restoration and Waste Management Programs Final Environmental Impact Statement, DOE/EIS-O203-F, U.S. Department of Energy, Idaho Falls, Idaho.

DOE, 1995d, Preliminary Requirements for the Disposition of DOE Spent Nuclear Fuel in a Deep Geological Repository, DI: A00000000-00811-1708-00006 Rev 00., US Department of Energy Office of Civilian Radioactive Waste Management.

DOE, 1995d, Quality Assurance Requirements and Description (QARD) DOE/RW-0333P Rev. 5, US Department of Energy Office of Civilian Radioactive Waste Management.

DOE, 1996a, Final Environmental Impact Statement: Management of Spent Nuclear Fuel from the $K$ Basins at the Hanford Site, DOE/EIS-0245F, U. S. Department of Energy, Richland, Washington.

DOE, 1996b, Transmittal of the Amendment to the Record of Decision for the Department of Energy (DOE) Programmatic Spent Nuclear Fuel Management and ..., DOE Letter to the Public, U.S. Department of Energy, Idaho Falls, Idaho.

DOE, 1996c, Programmatic Agreement Among the Department of Energy Richland Operations Office, Advisory Council on Historic Preservations and Washington State Historic Preservations for the Maintenance, Deactivation, Alteration, and Demolition of the built environment on the Hanford Site, U.S. Department of Energy, Richland, Washington.

Goldmann, L. H., 1996, Performance Specification for Design of the Spent Nuclear Fuel Multiple Canister Overpack, WHC-S-0426, Rev 1, Westinghouse Hanford Company, Richland, Washington.

Government Institutes, 1992, NEPA Compliance Manual, Freeman, L. R., March F., Los Alamos Technical Associates; and Spensley J. W., Holme, Roberts \& Owen, Government Institutes, Inc., Rockville, Maryland. 
Hanson, G. L., Jackson, R. R., 1978, Safety Assessment Document - PWR Core 2 Project, RHO-CD-356, Rockwell Hanford Operations, Richland, Washington.

Hillner, E., 1980, Corrosion and Hydriding Performance Evaluation of Three Zircaloy-2 Clad Fuel Assemblies After Continuous Exposure in PWR Cores 1 and 2 at Shippingport, Pa., WAPD-TM-1412, Bettis Atomic Power Laboratory, West Mifflin, Pennsylvania.

IAEA, 1982, Storage of water reactor Spent Fuel in Water Pools: Survey of World Experience, Technical Report Series 290, IAEA, Vienna, Austria.

IAEA, 1988, Survey of Experience with Dry Storage of Spent Nuclear Fuel and Update of Wet Storage Experience, Technical Report Series 290, IAEA, Vienna, Austria.

IAEA, 1992, Extended Storage of Spent Fuel - Final Report of a Co-ordinated Research Programme on the Behavior of Spent Fuel and Storage Facility Components During Long Term Storage, IAEA-TECDOC-673, International Atomic Energy Agency.

Johnson, A. B., 1977, Behavior of Spent Nuclear Fuel in water Pool Storage, BNWL-2256/UC-70, Battelle, Pacific Northwest Laboratory, Richland, Washington.

Johnson, A. B., Bailey, W. J., Bradley, E. R., Bruemmer, S. M., Langstaff, D. C., 1981, Spent Fuel and Fuel Pool Component Integrity, PNL-3868, Pacific Northwest Laboratory, Richland, Washington.

Johnson, A. B., Jr. 1994, Bases For Extrapolating Materials Durability In fuel Storage Pools, Paper From American Nuclear Society Meeting, December 1994, - DOE Spent Nuclear Fuel Challenges \& Initiatives, Pacific Northwest Laboratory, Richland, Washington.

Johnson, A. B., Jr., 1982, Materials Behavior In interim storage of Spent Fuel, PNL-SA-10553, Am. Nucl. Soc. Trans, 43:314-315.

Kee, A. T., 1995, Specification for SNF Path Forward Cask and Transportation System, WHC-S-0396, Rev 1, Westinghouse Hanford Company, Richland, Washington.

Kelly, J. L., 1975, Description of the PWR Core 2 Blanket Assemblies and M-160 Shipping Container, WAPD-LD-(RM)-236, Westinghouse Electric Corporation, West Mifflin, Pennsylvania.

Kustas F. M., Bates, S. O., Opitz, B. E., Johnson, A. B., Perez, J. M., Farnsworth, R. K., 1981, Investigation of the Condition of Spent Fuel Components, PNL-3513, Pacific Northwest Laboratory, Richland, Washington.

Longstaff D. C., 1982, Examination of Stainless Steel-Clad Connecticut Yankee Assembly SOO4 After Storage In Borated Water, PNL-3828, Pacific Northwest Laboratory, Richland, Washington.

Lourant, I. O., 1991, Potential Exposure Rates from PWR CORE I/ Fuel Assemblies - A Technical Assessment using: Isoshld-PC Calculations, WHC-SD-SOA-TA-20019, Rev. O, Westinghouse Hanford Company, Richland, Washington. 
McCormack, R. L., 1996, Other Spent Nuclear Fuel Management at the Canister Storage Building Complex, Letter Report 9650790, Westinghouse Hanford Company, Richland, Washington.

Miller, R. L., 1978, Criticality Safety Analysis Report for Criticality Prevention Specification 80.10-3 - PWR Core 2 Blanket Fuel Storage Cell 4, 221-T Building.

WHC-SD-SQA-CSA-20153, Rockwell Hanford Operations, Richland, Washington.

Monthey, M.J., Bergsman, K.H., 1994, Commercially Available Dry Storage Systems for Storage of Irradiated Fuel on the Hanford Site, WHC-SD-CP-ES-155, Rev. 0 , Westinghouse Hanford Company, Richland, Washington.

Peehs, M., Fleisch, J., 1986, LWR Spent Fue/ Storage Behavior, J. Nucl. Mater, 137.

Wargo, J. E., 1987, Light Water Breeder Reactor End-of-Life Component Examinations at Shippingport Atomic Power Station and Module Visual and Dimensional Examinations at Expended Core Facility, WAPD-TM-1602, Bettis Atomic Power Laboratory, West Mifflin, Pennsylvania.

WHC, 1992, Nuclear Material Control and Accountability Manual, WHC-CM-4-34, Westinghouse Hanford Company, Richland, Washington.

WHC, 1993, Hanford Site Solid Waste Acceptance Criteria, WHC-EP-0063-4, Westinghouse Hanford Company, Richland, Washington.

WHC, 1995a, Hazardous Material Packaging and Shipping, Part IV - Radioactive Material Shipments, WHC-CM-2-14, Westinghouse Hanford Company, Richland, Washington.

WHC, 1995b, Performance Specification for the $K$ Basin Spent Nuclear Fuel Vacuum Drying Module, WHC-S-0435, Rev. B, Westinghouse Hanford Company, Richland, Washington.

WHC, 1995c, Safety Analysis Report for Packaging (onsite) Format, DI-84100-002-02, Westinghouse Hanford Company, Richland, Washington.

WHC, 1995d, Solid Waste Disposal Operations Administration, WHC-CM-5-34, Westinghouse Hanford Company, Richland, Washington.

WHC, 1995e, Standard Operating Practices, WHC-CM-1-5, Westinghouse Hanford Company, Richland, Washington.

WHC, 1996a, Interim Safety Basis for Solid Waste Facilities (T Plant) - Draft, WHC-SD-WM-ISB-006, Westinghouse Hanford Company, Richland, Washington.

WHC, 1996b, Safety Analysis Manual, Number 9.0-Safety Structures, Systems and Components, WHC-CM-4-46, Westinghouse Hanford Company, Richland, Washington. 
WHC, 1996c, Spent Nuclear Fue/ Conditioning Product Criteria, WHC-SD-SNF-OCD-001, Rev. O, Westinghouse Hanford Company, Richland, Washington.

WHC, 1996d, T Plant Interim Operational Safety Requirements, WHC-SD-WM-TSR-003, Rev. O, Westinghouse Hanford Company, Richland, Washington.

WHC, 1996e, Annotated Outline for the Canister Storage Building Final Safety Analysis Report - DRAFT, Westinghouse Hanford Company, Richland, Washington. 
This page intentionally left blank. 


\section{APPENDIX A}

\section{CONTINUED STORAGE OF THE}

PWR-2 FUEL ASSEMBLIES IN THE T Plant POOL 


\section{CONTENTS}

A.O CONTINUED STORAGE OF THE PWR-2 FUEL ASSEMBLIES IN THE T Plant

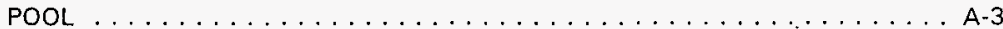

A. 1 PWR-2 FUEL ASSEMBLY CLADOING DETERIORATION $\ldots \ldots \ldots \ldots \ldots \ldots \ldots$. . . .

A.2 PWR-2 FUEL ASSEMBLY EXTENSION BRACKET DETERIORATION . . . . . . . A A-5

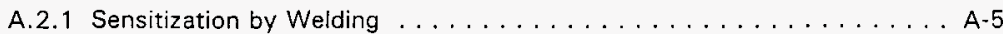

A.2.2 Sensitization by Heat Treatment . . . . . . . . . . . . . . A-6

A.2.3 Sensitization Due to In-Reactor Temperatures . . . . . . . . . . . A A-6

A.3 POOL WATER QUALITY AND SERVICE EQUIPMENT. . . . . . . . . . . A A-6

A.4 STORAGE POOL, BUILDING, AND BUILDING SERVICES DETERIORATION. . . . A-7

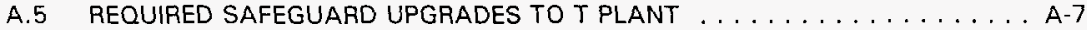

\section{LIST OF TABLES}

A-1. Summary of SNF Examinations to Define Status of Pool Stored Fuel . . . . . A-4 


\section{A.O CONTINUED STORAGE OF THE PWR-2 FUEL ASSEMBLIES IN THE T Plant POOL}

The following durability assessment considers the viability of continued storage of the PWR-2 fuel assemblies in the $T$ Plant storage pool. The assessment assumes that continued $T$ Plant storage may be required for the next 40 years, the anticipated duration required prior to shipment of SNF from the CSB to a final disposal facility. The review considers the various physical factors having the capability to affect the long-term storage of the PWR-2 fuel assemblies in their present storage pool in the T Plant canyon. Economic advantages and disadvantages of continued storage at $T$ Plant to alternative storage in another building or area are not compared in this study.

The factors that can affect the viability of T Plant wet storage of PWR-2 fuel for an additional 40 years are:

- PWR-2 fuel assembly cladding deterioration

- PWR-2 fuel assembly extension bracket deterioration

- Pool water quality and service equipment

- Storage pool, building, and building services deterioration

- Required safeguard upgrades to T Plant when the PWR-2 fuel becomes non-self protecting

These factors are discussed in detail in the following sections.

\section{A.1 PWR-2 FUEL ASSEMBLY CLADDING DETERIORATION}

Several studies have reviewed the durability of SNF in water storage pools (Peehs and Fleisch 1986; Bradley et al. 1981; Johnson et al. 1981; Clayton et al. 1993;

IAEA 1982, 1988, 1992). Included in these studies are reviews of zircaloy clad PWR fuel assemblies similar to the PWR-2 assemblies in T Plant. Table A-1 is an abridged extract from the International Atomic Energy Agency Technical Document, reference IAEA-TECDOC-673, Table $V$. The table contains a summary of zircaloy clad spent fuel examinations conducted after prolonged water storage. 
Table A-1. Summary of SNF Examinations to Define Status of Pool Stored Fuel.

\begin{tabular}{|c|c|c|c|c|c|}
\hline Fuel type/reactor & $\begin{array}{l}\text { Where } \\
\text { inspected }\end{array}$ & $\begin{array}{c}\text { First } \\
\text { Water } \\
\text { storage }\end{array}$ & $\begin{array}{c}\text { Last } \\
\text { examined }\end{array}$ & How examined & Remarks \\
\hline Zircaloy $/ \mathrm{UO}_{2} / \mathrm{PWR}$ & Germany & 1974 & 1982 & $\begin{array}{l}\text { NDT/eddy } \\
\text { current/ } \\
\text { profilometry/ } \\
\text { visual }\end{array}$ & $\begin{array}{l}\text { No evidence that } \\
\text { reactor induced } \\
\text { defects are } \\
\text { changing; no } \\
\text { evidence that } \\
\text { intact cladding is } \\
\text { degrading } \\
\end{array}$ \\
\hline Zircaloy $/ \mathrm{UO}_{2} / \mathrm{PWR}$ & UK & 1972 & 1977 & NDT/hot cell & $\begin{array}{l}\text { No evidence of } \\
\text { pool induced } \\
\text { degradation }\end{array}$ \\
\hline Zircaloy $/ \mathrm{UO}_{2} / \mathrm{BWR}$ & UK & 1971 & 1977 & NDT/hot cell & $\begin{array}{l}\text { No evidence of } \\
\text { pool induced } \\
\text { degradation }\end{array}$ \\
\hline $\begin{array}{l}\text { Zircaloy/UO } / \\
\text { SGHWR }\end{array}$ & UK & 1968 & 1977 & Hot cell & $\begin{array}{l}\text { No significant } \\
\text { degradation at } \\
\text { reactor induced } \\
\text { defects } \\
\end{array}$ \\
\hline $\begin{array}{l}\text { Zircaloy } / \mathrm{UO}_{2} / \\
\text { PHWR }\end{array}$ & UK & 1966 & 1977 & NDT/hot cell & $\begin{array}{l}\text { No evidence of } \\
\text { pool induced } \\
\text { degradation }\end{array}$ \\
\hline Zircalov $/ \mathrm{UO}_{2} / \mathrm{NRU}$ & Canada & 1962 & 1978 & NDT/hot cell & $\begin{array}{l}\text { No evidence of } \\
\text { pool induced } \\
\text { degradation }\end{array}$ \\
\hline $\begin{array}{l}\text { Zircaloy/UO } / \\
\text { Shippingport/PWR }\end{array}$ & USA & 1959 & 1980 & NDT/hot cell & $\begin{array}{l}\text { No evidence of } \\
\text { pool induced } \\
\text { degradation }\end{array}$ \\
\hline Zircaloy $/ \mathrm{UO}_{2} /$ PWR & USA & 1974 & 1982 & $\begin{array}{l}\text { Visual/photo/ } \\
\text { scan }\end{array}$ & $\begin{array}{l}\text { No evidence that } \\
\text { test reactor } \\
\text { induced defects } \\
\text { are changing; } \\
\text { crud appears to } \\
\text { be loosening }\end{array}$ \\
\hline
\end{tabular}

Note:

NDT - Non-destructive testing.

As seen in Table A-1, fuel assembly examinations on intact fuel found no evidence of any degradation induced during pool storage. Examinations on fuel with existing reactor induced defects also found no evidence of further degradation induced by pool storage.

Mr. A. B. Johnson of the Pacific Northwest National Laboratory (PNNL) states in his paper titled Bases For Extrapolating Materials Durability In Fuel Storage Pools (DOE Spent Nuclear Fuel-Challenges \& Initiatives, 1994), "A major body of evidence indicates that 
zirconium alloys have the most consistent and reliable durability in wet storage, justifying projections of safe wet storage greater than 50 years." He also states following a review of zirconium alloy SNF examinations and observations, "..........there is no evidence that zirconium alloy fuel cladding has degraded detectably in wet storage over periods up to 35 years and including several million fuel rods. Sequential photographs aiso have confirmed that holes in cladding that developed during reactor service do not change size or shape (observations up to eight years) while exposed to pool water (Peehs and Fleisch 1986; Johnson et al. 1982). ...... Oxide fuel pellets exposed at the cladding defects also are stable over long periods."

In view of the previous statements, continued storage of the PWR-2 fuel assemblies in the T Plant storage pool for the next 40 years is not likely to result in any further degradation of the fuel assembly zircaloy cladding. As stated previously in this section, available evidence indicates that the zircaloy cladding is not breached on the PWR-2 assemblies. However, studies indicate that even if the cladding is breached, uranium oxide fuel when exposed to water is very stable, and exposure will not result in accelerated degradation of the fuel assembly. Rather It will result in a slow leaching of fission products (primarily cesium-137) to the pool water, which would be readily observable during pool monitoring.

\section{A.2 PWR-2 FUEL ASSEMBLY EXTENSION BRACKET DETERIORATION}

The stainless steel top extension bracket attached to each PWR-2 fuel assembly is designed with lifting and engagement slots to accommodate a fuel assembly lifting grapple. Failure of these lifting slots would jeopardize future retrieval operations. The following review examines the susceptibility of the extension brackets to degradation.

Mr. A. B. Johnson states (DOE Spent Nuclear Fuel-Challenges \& Initiatives, 1994) "...stainless steel is extremely durable when stress, metallurgical, and water chemistry factors are controlled. Light Water Reactor stainiess steel cladding has survived for 25 years in wet storage. However, sensitized, stressed stainless steel fuels and components have seriously degraded in fuel storage pools at $\approx 30^{\circ} \mathrm{C}\left(86^{\circ} \mathrm{F}\right)$ (Ambient temperatures)." Sensitization of stainless steel generally occurs due to:

- Welding of the stainless steel creating localized heat affected zones.

- Heat treatment of the stainless steel between $500^{\circ} \mathrm{C}-700^{\circ} \mathrm{C}\left[932^{\circ} \mathrm{F}\right.$ to $\left.1292^{\circ} \mathrm{F}\right]$ ).

- Prolonged in-reactor temperatures above $350^{\circ} \mathrm{C}\left(662^{\circ} \mathrm{F}\right\}$.

\section{A.2.1 Sensitization by Welding}

The extension brackets, and (four) bolts that fasten each extension bracket to the zircaloy fuel cluster, are constructed from 304 stainless steel and machined from solid bar (drawing numbers $911 \mathrm{F888} \& 911 \mathrm{~B} 241$ ). Neither of these items have construction welds. Therefore, they do not contain heat effected areas, caused by welding, that can result in accelerated corrosion. 


\section{A.2.2 Sensitization by Heat Treatment}

Both the extension brackets and bolts were heat treated to anneal the stainless steel. The extension brackets were heated to $1,010^{\circ} \mathrm{C}\left(1,850^{\circ} \mathrm{F}\right)$ in a natural to slightly oxidizing atmosphere (to stress relieve the metal) prior to final machining. The fuel assembly bolts were heated to $1,010^{\circ} \mathrm{C}\left(1,850^{\circ} \mathrm{F}\right)$ for 30 minutes in a dry hydrogen atmosphere prior to use. Neither of these two processes will lead to sensitization of the stainless steel since:

1. Annealing temperature was above $700^{\circ} \mathrm{C}\left(1,292^{\circ} \mathrm{F}\right)$ causing homogenization of the stainless steel.

2. Cooling was designed to result in a limited residence time in the 500 to $700^{\circ} \mathrm{C}\left(932\right.$ to $\left.1,292^{\circ} \mathrm{F}\right)$ sensitization temperature range.

\section{A.2.3 Sensitization Due to In-Reactor Temperatures}

The designed (average) Shippingport reactor core cooling water temperature was $266^{\circ} \mathrm{C}\left(536^{\circ} \mathrm{F}\right)$ (WAPD-296). This is $84^{\circ} \mathrm{C}\left(183^{\circ} \mathrm{F}\right)$ below the prolonged senizatation reactor temperature $\left(350^{\circ} \mathrm{C}\left[662^{\circ} \mathrm{F}\right]\right)$ mentioned above. It is therefore improbable that sensatization of the stainless steel has occurred due to long-term exposure to elevated temperatures in the reactor core.

It is unlikely that any of the sensitization mechanisms have been applied to the PWR-2 top or bottom extension brackets and bolts. Subsequently, sensitization of the stainless steel, allowing inter-granular and stress corrosion cracking, is not believed to be a problem when assessing the life of the stainless steel fuel assembly elements.

Another common failure mechanism of stainless steel is crevice corrosion cracking. Crevice corrosion cracking is difficult to initiate in a radiation environment and, if occurring, is readily observable as visible corrosion products are formed. None have been noted on the extension brackets. The general corrosion rate for 304 stainless steel in good quality pool water (as currently exists in the T Plant pool) is less than one micron per year (information from BNFL Sellafield) and is therefore not anticipated to be a problem during an additional 40 year storage period. For further information on the corrosion of stainless steel in pool storage see Kustas et al. (1981), Longstaff et al. (1982), and Johnson (1977).

Based on the previous considerations and the known history of the PWR-2 fuel, it is likely that the PWR-2 fuel assemblies can continue to be stored in the water pool for an additional 40 years without problematic degradation, provided the pool water quality is maintained within its present limits.

\section{A.3 POOL WATER QUALITY AND SERVICE EQUIPMENT.}

IAEE (1992) states, "....monitoring and surveillance have confirmed that adherence to the specified pool water chemistry (near neutral PH conditions with low ion content for zirconium clad fuels) is essential to prevent fuel degradation during pool storage for all types of spent fuel." It is therefore essential that pool water quality and support 
equipment (filters, ion exchange column, and demineralizers) are maintained in good condition. This will require the maintenance or replacement of defective equipment. As equipment of this type is readily available, this is not anticipated to be a major problem. It is noted that the T Plant pool water chilling equipment has been deactivated. Therefore, care must be taken to detect and eliminate any algae growth in the pool.

\section{A.4 STORAGE POOL, BUILDING, AND BUILDING SERVICES DETERIORATION.}

When considering an additional 40 years of SNF storage in the T Plant canyon, maintaining the storage pool, canyon building, and building services in good condition is likely to be the major expense. The building was constructed in 1944 and although now is over 50 years old, it is a substantial structure that will require maintenance (repair of cracks and spalled concrete, new doors and windows, etc.) to last another 40 years. Repair or replacement of the building services equipment is likely to be a major expense over this period as the canyon crane, ventilation equipment, power supplies, lighting, closed circuit television, communications equipment, etc. are required to be repaired or replaced. For example, it is possible that replacement of the overhead crane could cost in the order of $\$ 1$ million including installation. Otherwise a portable "gantry" crane would need to be erected within the canyon to provide for fuel retrieval. Maintaining the storage pool as a leak tight structure in good condition is an unknown. The main failure mechanisms with an unlined pool (as at T Plant) is cracking of the structure and surface carbonation of the concrete. Both will result in corrosion of the pool concrete steel reinforcement, spalling of the concrete surface, and pool leakage. Inspections can confirm the condition of the pool structure and the pool can be repaired and/or lined if necessary, but at a significant cost.

The difficulty and cost of maintaining the storage pool, canyon building, and service equipment in a good operating condition for the next 40 years is likely to be one of the determining factors in any decision on the viability of continued storage of the PWR-2 fuel in T Plant.

\section{A.5 REQUIRED SAFEGUARD UPGRADES TO T PLANT}

If, as presently calculated, the PWR-2 fuel assemblies cease to be self protecting sometime after the year 2004 , the safeguards requirements at $T$ Plant will be required to satisfy the security requirements of a protected area as specified in DOE Order $5632.1 \mathrm{C}-1$ (Manual for Protection and Control of Security Interests, DOE 1994). To satisfy these requirements, it is likely that security upgrades will be needed on the present $T$ Plant security system. The actual upgrades required (and associated costs) are not known at this time as a graded approach to security dependent upon risk is mandated by DOE Order 5632.1C-1. A Vuinerability Assessment (VA) will need to be undertaken by the Hanford Site Security department to determine actual upgrade requirements. 
This page intentionally left blank.

A-8 
APPENDIX B

\section{ALTERNATIVE CASK STORAGE EVALUATION}




\section{CONTENTS}

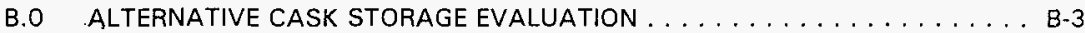

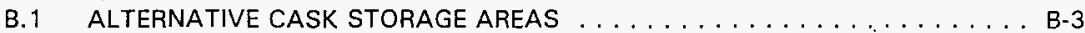

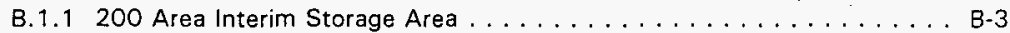

B.1.2 Plutonium Finishing Plant Interim Storage Area . . . . . . . . . B-5

B.1.3 400 Area Interim Storage Area . . . . . . . . . . . . . . B-5

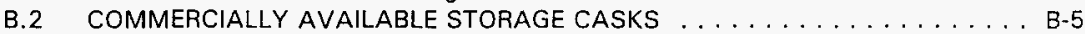

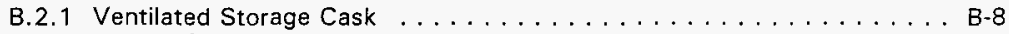

B.2.2 Nuhoms system ... . . . . . . . . . . . . . . . . B-12

B.3 FUEL ASSEMBLY LOADING AT T PLANT $\ldots \ldots \ldots \ldots \ldots \ldots \ldots \ldots \ldots \ldots$

B.4 TRANSPORT FROM T PLANT TO INTERIM STORAGE AREA . . . . . . . . B-14

B.5 OFFSITE TRANSPORT AND REPOSITORY ACCEPTANCE REQUIREMENTS . . B-16

\section{LIST OF FIGURES}

B-1. 200 Area Interim Storage Area . . . . . . . . . . . . . . . . B-4

B-2. Plutonium Finishing Plant SNF Storage Areas . . . . . . . . . . . . B-6

B-3. Ventilated Storage Cask System . . . . . . . . . . . . . . . . B-8

B-4. Vectra's Nuhoms SNF Storage System . . . . . . . . . . . . . . . B-12

B-5. PWR-2 Fuel Assemblies Removal Schedule (Storage in Aboveground Storage Casks) . . . . . . . . . . . . . . . . . .

\section{LIST OF TABLES}

B-1. Commercially Available SNF Storage Systems . . . . . . . . . . . B-7

B-2. PWR-2 Fuel Assemblies Removal Cost Estimate - VSC Storage . . . . . . . . B-17

B-3. PWR-2 Fuel Assemblies Removal Cost Estimate - Nuhoms Storage . . . . . . . B-18 


\section{B.O ALTERNATIVE CASK STORAGE EVALUATION}

This section identifies alternative storage options (other than the CSB) for interim storage of the PWR-2 fuel assemblies. This includes evaluation of commercially available storage casks and alternative storage locations.

\section{B.1 ALTERNATIVE CASK STORAGE AREAS}

It is currently assumed that the PWR-2 fuel assemblies will be placed in nine storage tubes inside the first CSB vault. However, there is a possibility that some or all of these tubes will be needed for storage of $\mathrm{K}$ Basin SNF. If this is the case, an alternative storage location for some or all of the PWR-2 fuel assemblies will be required if it is decided to remove them from T Plant. The following locations have been identified on the Hanford Site that currently store or will store SNF in approved storage casks and which can be considered for the storage of PWR-2 fuel assemblies.

\section{B.1.1 200 Area Interim Storage Area}

The 200 Area ISA is to be built west of the CSB for the external storage of "other" various SNF in storage casks. This will include Fast Flux Test Facility (FFTF) fuel assemblies in interim storage casks (ISC), Light Water Reactor storage casks, and TRIGA storage casks. Design of the 200 Area ISA is expected to begin in 1998 with construction of the storage area beginning in 1999. Spent fuel would be stored in the ISA beginning in the year 2000. See Figure B-1 for the current ISA design.

The 200 Area ISA is envisioned to be a large (approximately $120 \mathrm{~m}$ by $150 \mathrm{~m}$ $[400 \mathrm{ft}$ by $500 \mathrm{ft}]$ ) open area surrounded by a single chain-link fence. Concrete pads would be constructed for the laydown area for each type of SNF storage cask. The area would be lighted but would not be subjected to continuous manned surveillance. Only self protecting SNF (greater than $100 \mathrm{R} / \mathrm{hr}$ at $1 \mathrm{~m}[3.3 \mathrm{ft}]$ ) will be allowed to be stored in this ISA according to DOE regulations. Calculations show that the PWR-2 fuel assemblies will become non-self protecting sometime after the year 2004. At this time, the current 200 Area ISA design will not have the safeguard security requirements as defined by DOE. Therefore, as proposed, the 200 Area ISA is not suitable as an interim storage alternative for PWR-2 fuel assemblies without extensive security upgrades. The assemblies could be stored in the 200 Area ISA from 1999 to 2004 (approximate) and then moved to a protected area; however, this is not considered a cost effective option. To upgrade the ISA to meet non-self protecting storage requirements, a second security fence would need to be installed with motion detectors, CCTV, and a permanent 24-hour dedicated security force, operating roving patrois, and a security watch tower. 
Figure B-1. 200 Area Interim Storage Area.

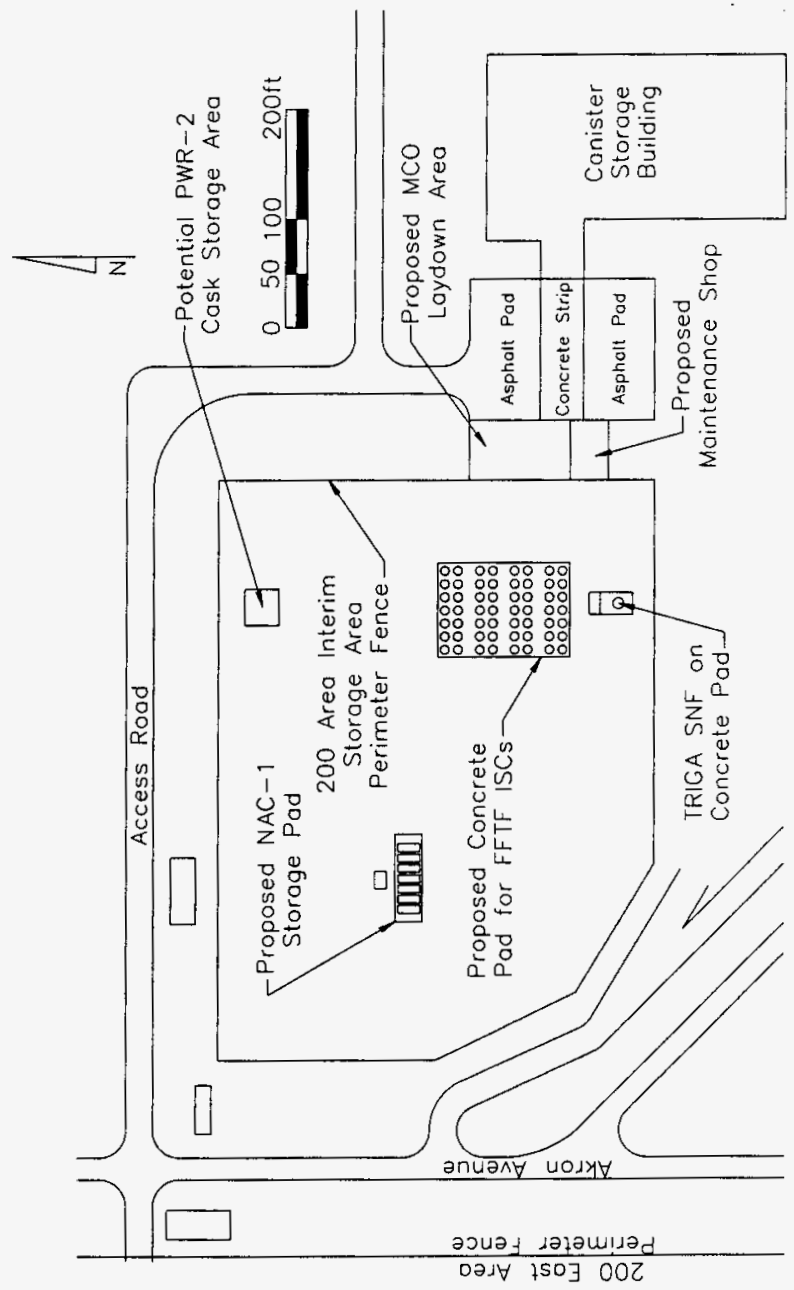




\section{B.1.2 Plutonium Finishing Plant Interim Storage Area}

The PFP complex is located in the western section of the 200 West Area. Although the plutonium processing mission of the plant has been terminated, there are still large quantities of plutonium metal and other materials stored at the complex. Because of this continuing storage mission, the complex maintains a high level of security that meets or exceeds the security arrangements required for non-self protecting SNF. Because of this, vacant areas within the PFP security perimeter are being used for storage of non-self protecting Los Alamos Molten Plutonium Reactor Experiment (LAMPRE) fuel stored in Experimental Breeder Reactor (EBR) - II storage casks within a concrete vault. PFP will also store eight FFTF ISC casks in the near future. The existing level of security at PFP is anticipated to be in place for the foreseeable future. Figure B-2 shows the PFP complex with current and proposed SNF storage locations.

The LAMPRE fuel assemblies are currently being stored in a storage vault located south and central within the PFP complex. The FFTF ISC casks will probably be stored on a concrete pad located in the southwest corner of the complex. Following discussions with PFP management, it was determined that there is sufficient room for three PWR-2 storage casks. It is envisioned that these casks would be stored on a concrete storage pad either in the northwest corner or adjacent to the FFTF casks in the southwest corner of the complex.

\section{B.1.3 400 Area Interim Storage Area}

The 400 Area also has an ISA for storage of FFTF SNF. It is currently proposed to transfer this SNF to either the 200 Area ISA or to PFP, depending on each cask's fuel safeguards classification. Since the 400 Area is due to be decommissioned or transferred to private industry, the use of the 400 Area ISA for storage of PWR-2 fuel assembly storage casks has been removed from consideration.

\section{B.2 COMMERCIALLY AVAILABLE STORAGE CASKS}

In the WHC document, Commercially Available Dry Storage Systems for Storage of Irradiated Fuel on the Hanford Site (Monthey and Bergsman 1994), several dry storage cask systems were examined. An abbreviated list of these storage systems are listed in Table B-1. Information presented in this section is based primarily on this WHC document but has been updated after contacts with the various cask manufacturers.

Two of these dry storage cask systems were picked as representative typical systems for storage of PWR-2 fuel assemblies and are examined in detail in the following subsections. These systems are the Sierra Nuclear's VSC and Vectra's Nuhoms system. These systems appear to be the best options for cask storage of the PWR-2 fuel assemblies. 
Figure B-2. Plutonium Finishing Plant SNF Storage Areas.

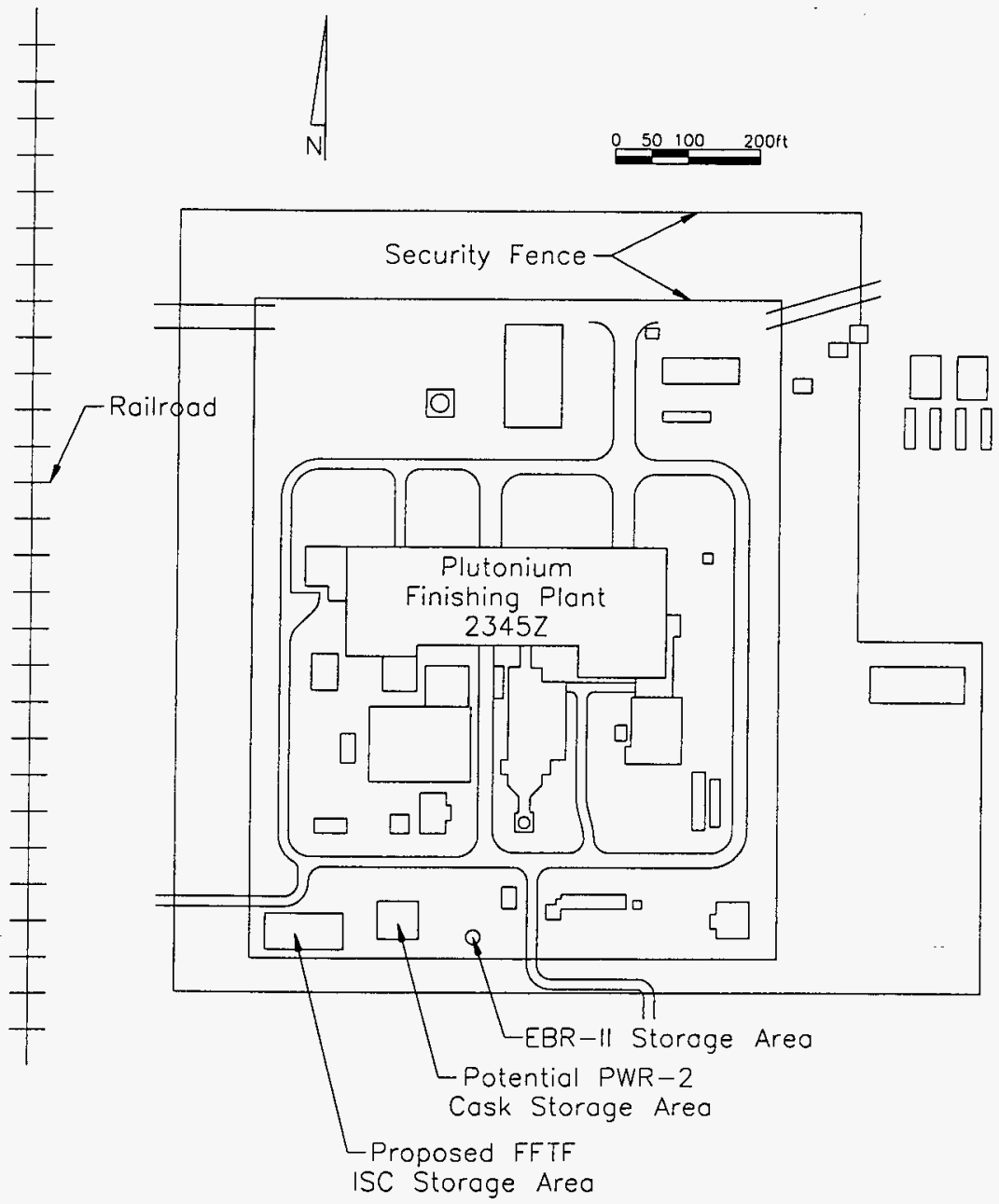


Table B-1. Commercially Available SNF Storage Systems.

\begin{tabular}{|c|c|c|c|c|c|c|c|c|c|c|}
\hline & $\begin{array}{c}\text { NAC-S/T } \\
\text { NAC }\end{array}$ & $\begin{array}{l}\text { NAC-STC } \\
\text { NAC } \\
\end{array}$ & $\begin{array}{c}\text { TN-12Y } \\
\text { Transnuclear }\end{array}$ & \begin{tabular}{c|} 
TN-24 \\
Transnuclear \\
\end{tabular} & $\begin{array}{c}\text { TN-REG } \\
\text { Transnuclear }\end{array}$ & $\begin{array}{c}\text { VSC-24 } \\
\text { Sierra }\end{array}$ & $\begin{array}{l}\text { Nuhoms' } \\
\text { VECTRA }\end{array}$ & $\begin{array}{l}\text { MACSTOR } \\
\text { Transmuclear }\end{array}$ & $\begin{array}{l}\text { HI-STAR } \\
\text { Holtec }\end{array}$ & $\begin{array}{c}\text { Ht-Storm } \\
\text { Holtec }\end{array}$ \\
\hline Capacity (PWR fuel) & 26 & 28 & 12 & 24 & 20 & 24 & 24 & 12 & 32 & 32 \\
\hline $\begin{array}{l}\text { Number Casks } \\
\text { Required for } 72 \\
\text { PWR-2 Assemblies }\end{array}$ & 3 & 3 & 6 & 3 & 4 & 3 & 3 & 6 & 3 & 3 \\
\hline Fuel Orientation & Vertical & Vertical & & Vertical & $\begin{array}{l}\text { Transport } \\
\text { Horizontal. } \\
\text { Storage } \\
\text { Vertical }\end{array}$ & Vertical & $\begin{array}{l}\text { Loaded } \\
\text { Vertical, } \\
\text { Shipped and } \\
\text { Stored } \\
\text { Horizontal }\end{array}$ & Vertical & Vertical & Both \\
\hline $\begin{array}{l}\text { Inside Length } \\
\text { (cm linches]) }\end{array}$ & $417|164|$ & $419[165]$ & $457[180]$ & $415[163.25]$ & & Fit to Fuel & $424[167]$ & $411\lfloor 162\rfloor$ & $\begin{array}{l}<475.6 \\
|<187.2|\end{array}$ & $\begin{array}{l}<475.6 \\
\mid<187.2]\end{array}$ \\
\hline $\begin{array}{l}\text { Inside Diameter } \\
\text { (cm [inches]! }\end{array}$ & $164[64.7]$ & $180[71]$ & $122[48]$ & $160\lfloor 63\rfloor$ & $\begin{array}{l}182.2 \\
{[71.75]} \\
\end{array}$ & $\begin{array}{l}179 \\
{[70.5]} \\
\end{array}$ & $\begin{array}{l}168 \\
{[66]} \\
\end{array}$ & $\begin{array}{l}127 \\
{[50]} \\
\end{array}$ & $\begin{array}{l}174 \\
{[<68.5]}\end{array}$ & $\begin{array}{l}174 \\
|<68.5|\end{array}$ \\
\hline Internal Atmosphere & Helium & Helium & $\begin{array}{l}\text { Air or Inert } \\
\text { gas }\end{array}$ & Helium & & Helium & Helium & & Helium & Helium \\
\hline $\begin{array}{l}\text { Loaded Weight } \\
\text { (tons) }\end{array}$ & 100 & 100 & 106.9 & 107 & 112.5 & 125 & 125 & $N / A$ & $100-125$ & $100-125$ \\
\hline $\begin{array}{l}\text { Estimated Schedule } \\
\text { for Manufacture }\end{array}$ & $\begin{array}{l}18 \text { mon. } 1 \text { st } \\
1 \text { per mon. }\end{array}$ & $\begin{array}{l}18 \text { mon. } 1 \mathrm{st} \\
1 \text { per mon. }\end{array}$ & $\begin{array}{l}12 \text { mon. } 1 \text { st } \\
1 \text { per week }\end{array}$ & $\begin{array}{l}12 \text { mon. } 1 \text { st } \\
1 \text { per week }\end{array}$ & $\begin{array}{l}12 \text { mon. } 1 \text { st } \\
1 \text { per week }\end{array}$ & $\begin{array}{l}12 \text { mon. } 1 \text { st } \\
1 \text { per week }\end{array}$ & $\begin{array}{l}6 \text { to } 12 \\
\text { months }\end{array}$ & 18 months & \multicolumn{2}{|c|}{$\begin{array}{l}\text { These two systems will } \\
\text { not be approved and } \\
\text { manufactured until the } \\
\text { end of } 1997\end{array}$} \\
\hline $\begin{array}{l}\text { Rough Cask Cost } \\
\text { leach) }\end{array}$ & $\$ 1,000,000$ & $\$ 1,200,000$ & $\begin{array}{l}\$ 600,000 \\
1,000,000\end{array}$ & $\$ 1,000,000$ & $\$ 600,000$ & $\begin{array}{l}\$ 550,000+ \\
400,000 \text { for } \\
\text { transfer cask }\end{array}$ & $\begin{array}{l}\$ 375,000 \\
+1 \text { million } \\
\text { for transfer } \\
\text { equipment }\end{array}$ & $\$ 237,000$ & $?$ & $?$ \\
\hline
\end{tabular}




\section{B.2.1 Ventilated Storage Cask}

The VSC-24 is a dry storage system produced by Sierra Nuclear Corporation. It is capable of storing 24 PWR-2 fuel assemblies with its standard PWR SNF storage container. In addition, a custom VSC design can be easily developed las a modification of the basic design) to accommodate project specific requirements. The VSC system was designed and analyzed in accordance with 10 CFR 72 and a general Topical Safety Analysis Report (TSAR). According to the manufacturer, the system has a design lifetime of 50 years.

In the VSC system, the fuel assemblies would be contained in a Multiassembly Sealed Basket (MSB) that is stored vertically in the central cavity of a Ventilated Concrete Cask (VCC). The VCC is ventilated by internal air flow paths (unfiltered) that create a "chimney" effect and allow decay heat removal by natural circulation. To transfer SNF from a storage pool, a transfer cask (loaded with a MSB) is normally used. The VSC system can accommodate 5 year cooled, 35,000 MWD/MTU SNF without further analysis (PWR-2 fuel assemblies have cooled 23 years and have an average burnup of 16,000 MWD/MTU). An illustration of a VSC is shown in Figure B-3. The VSC is further described in the following subsections.

Figure B-3. Ventilated Storage Cask System. (IAEA 1992)

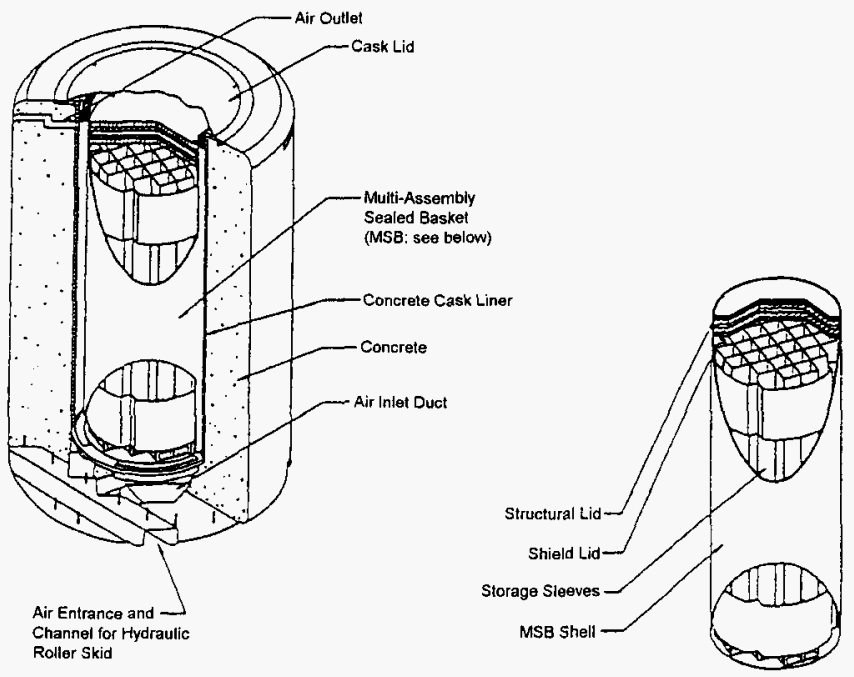


B.2.1.1 Multiassembly Sealed Basket. The MSB, which fits inside the concrete VCC, consists of a $157 \mathrm{~cm}(62$ in.) outside diameter steel shell $(2.5 \mathrm{~cm}$ [1 in.] thick) that contains the spent fuel in individual square tubing compartments. The MSB is $447 \mathrm{~cm}$ (176 in.) to $480 \mathrm{~cm}$ (189 in.) long, depending on fuel requirements. The standard PWR MSB is designed to hold 24 commercial PWR fuel assemblies (individual dimensions of $21.4 \mathrm{~cm}$ [8.42 in.] square and $399 \mathrm{~cm}$ [157 in.] longl. The top of the MSB is covered with both a shielded lid and a structural lid. The combination of the shield and structural lids provide a total $25 \mathrm{~cm}$ (10 in.) of steel and $5 \mathrm{~cm}(2 \mathrm{in.})$ of neutron absorbing concrete for shielding. The MSB is sealed by welding the shield and structural lids to the MSB body, vacuum drying the contents, and refilling with helium.

B.2.1.2 Ventilated Concrete Cask. The VCC is a concrete cask that has a $179 \mathrm{~cm} 170.5$ in.) inside diameter internal cavity formed by a $4.44 \mathrm{~cm}(1.75 \mathrm{in}$.) thick steel cylinder. The concrete external shell is a $73.7 \mathrm{~cm}$ [29 in.] thick wall made from Type II Portland Cement (4000 psi), which is reinforced with cages made from bar reinforcement. Four large air ducts are provided at the bottom of the cask (inlet) and at the top of the cask (outlet) for cooling. The ducts are steel-lined penetrations that take nonplanar paths to minimize radiation streaming. The top of the VCC is covered by a $1.9 \mathrm{~cm}(0.75 \mathrm{in}$.) thick steel plate that is bolted to the main body. Shielding for the top of the SNF is provided by the MSB, as previously described.

B.2.1.3 Onsite Transfer Cask. The transfer cask consists of a cylinder sized to fit the MSB with a steel-lead-steel-neutron, shield-steel sandwich wall. The wall has a total of 5

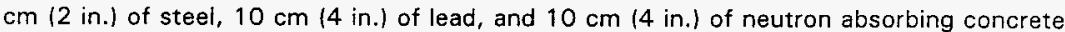
for shielding. The transfer cask has a top cover that extends over the MSB, preventing it from being inadvertently lifted out of the top of the transfer cask while being lowered into the VCC. It also has a movable shield door (hydraulically operated) at the bottom to allow lowering the MSB into the VCC. Pins are used to prevent inadvertent opening of the door. To transfer SNF from a storage pool, a transfer cask (loaded with a MSB) is normally submerged in the pool and loaded through the top opening. It is unloaded by vertical mating to the top of the VCC, and the MSB is lowered through the bottom opening.

After discussion with a Sierra Nuclear representative, it was recommended that the use of a transfer cask was unnecessary for this situation. The combination of the VCC and the MSB could be transferred to the T Plant tunnel and loaded directly from the storage pool using a similar dry transfer process as described in Section 7.0. The use of the transfer cask would only be necessary if a wet transfer process (submerging the transfer cask in the storage pool) were used to retrieve the PWR-2 fuel assemblies.

Because of the extreme weight (greater than 125 tons) of the VCC/MSB combination, it is assumed that a modified railroad car will be used to transfer the cask into and out of T Plant's railroad access tunnel for fuel loading. The use of a road transporter to transport the VCC/MSB combination directly into and out of the T Plant railroad tunnel is not considered viable because of the extensive costs associated with upgrading the tunnel access road and ramp. 
B.2.1.4 Advantages and Disadvantages. Advantages of the VSC system are discussed in the following.

- The VSC system is a proven technology with units being used by Consumers Power Company of Michigan and at the Trojan Nuclear Power Plant in Oregon.

- Because of the inexpensive method of fabrication and low material costs, the cost of the VSC is lower than an equivalent steel cask.

- The design of the VCC provides additional shielding and should provide lower external radiation levels than similar steel casks.

- It has been demonstrated by the cask designers that the cask basket can be modified to accommodate changes in numbers of fuel assemblies.

- Since the VCC can be moved directly to T Plant for fuel assembly loading, the purchase of a transfer cask would not be necessary.

Disadvantages to the VSC are discussed in the following:

- The VSC system is designed for onsite storage and short transfers only.

- Both a railroad and a road transporter would need to be rented to transfer the VCC/MSB combination from T Plant to the storage area.

- The VCC/MSB combination would need to be transferred twice by a heavy lift crane. Once from the railroad car to the road transporter and then from the road transporter to the storage pad.

8.2.1.5 Cost and Schedule Estimates. The MSBs have a cost of $\$ 250,000$ each as configured for PWR commercial fuel, which would be compatible with the PWR-2 fuel assemblies. The VCCs are fabricated onsite by a Sierra supplied construction crew. Due to construction crew mobilization costs, the cost of the VCC will vary depending on the quantity required. The cost for one VCC would be $\$ 200,000$, whereas the cost for 30 VCCs would be $\$ 100,000$ each. The transfer cask has a cost of $\$ 400,000$. A modified railroad car would need to be leased or purchased for transfer of the VCC. The purchase price of a modified railroad car is estimated to be $\$ 300,000$. A concrete storage padwould also need to be constructed for interim storage of the casks at an estimated cost of $\$ 100,000$. Therefore, the cost for transfer (discussed in Section B.4) and storage of all 72 PWR-2 Shippingport fuel assemblies using Sierra's VSC system is estimated to be $\$ 2.1$ million. This would increase the total cost for retrieval, transport, and storage of the fuel assemblies to $\$ 5.1$ million, including an 18 percent contingency. This total cost is summarized in Table B-2 at the end of this appendix.

The time required to build the VCCs would be dictated by the size of the construction crew. Eight VCCs were built in Michigan for the Palisades Nuclear Plant at a rate of one per week using a six-member construction crew. However, the lead time for the first VSC system would require several months to a year. The transfer process is 
estimated to take four months including one training cask and three loaded casks. A complete schedule of PWR-2 fuel assembly fuel retrieval using aboveground storage containers is shown in Figure B-5 at the end of this appendix.

\section{B.2.2 Nuhoms System}

The Nuhoms -24 system is an example of an outdoor facility built for interim dry storage of multiple canisters containing irradiated fuel. It consists of a three part system, a semi-shielded inner container with a basket [Dry Shielded Canister (DSC)], a fixed, multiple storage structure [Horizontal Storage Module (HSM)], and a shielded reusable transfer cask. The container and basket are placed inside the transfer cask and loaded with SNF. The standard design can hold up to 24 PWR-2 fuel assemblies. The combination is then transferred to the storage structure site where the container and basket are pushed through the transfer cask and inserted into a shielded storage unit in the HSM. The entire onsite storage system has an approved TSAR and is licensed by the Nuclear Regulatory Commission (NRC) under 10 CFR 72 for at-reactor storage operations. The Nuhoms ${ }^{\circ}$ system can accommodate SNF with a minimum of 5 years cooling time and a maximum fuel burnup of 40,000 MWD/MTU for PWR fuel assemblies (PWR-2 fuel assemblies have cooled 23 years and have an average burnup of 16,000 MWD/MTU). An illustration of a Nuhoms system is shown in Figure B-4. The Nuhoms ${ }^{\circledR}$ system is further described in the following subsections.

B.2.2.1 Dry Shielded Canister. The DSC is the semi-shielded transfer and storage canister for the Nuhoms system. It provides the primary radioactive containment boundary for storage and the secondary boundary for initial transportation. The shielding, located at the top and bottom, is designed to supplement the HSM shielding. The canister has a 170.8 $\mathrm{cm}$ (67.25 in.) outside diameter and is $498 \mathrm{~cm}$ (196 in.) long. The internal DSC cavity length and diameter are $450.8 \mathrm{~cm}(177.5 \mathrm{in}$.$) and 167.6 \mathrm{~cm}(66.0 \mathrm{in}$.$) , respectively. Wall$ thickness is $1.59 \mathrm{~cm}(0.625 \mathrm{in}$.). The DSC is sealed by welding the shielding lid to the MSB body, vacuum drying the contents, and refilling with helium.

B.2.2.2 Horizontal Storage Module. The HSM is a shielded, ventilated, precast concrete structure placed on a concrete basemat. The HSM is designed in accordance with ACl-349 Code (ACl 1989). The HSM can provide multiple storage positions in a "single-in-line" configuration or in double "back-to-back" line configuration. Single units measure approximately $2.9 \mathrm{~m}(9.7 \mathrm{ft})$ in width by $5.5 \mathrm{~m}(18.1 \mathrm{ft})$ in length by $4.5 \mathrm{~m}(15$ $\mathrm{ft}$ ) in height. The DSC is inserted horizontally into the opening in the front of the HSM using patented transfer equipment. It is supported on rails attached to a steel support structure within the HSM. Once the DSC is placed within the HSM, the shielded access door is tack welded into position.

B.2.2.3 Transfer Casks. The Nuhoms" system has both an onsite transfer and an offsite transportation cask available. Both are capable of holding a standard DSC. The offsite transportation cask is essentially the onsite transfer cask with stainless steel substituted for carbon steel, impact limiters, and redundant top cover plate seals. Small additional changes are being made to incorporate the puncture, fire, and radiation dose limits required by 10 CFR 71. Also required for loading the DSC into the HSM are the cask support skid, transporter trailer, and ramming apparatus that positions and pushes the DSC into the HSM. 
Figure B-4. Vectra's Nuhoms ${ }^{\circ}$ SNF Storage System.
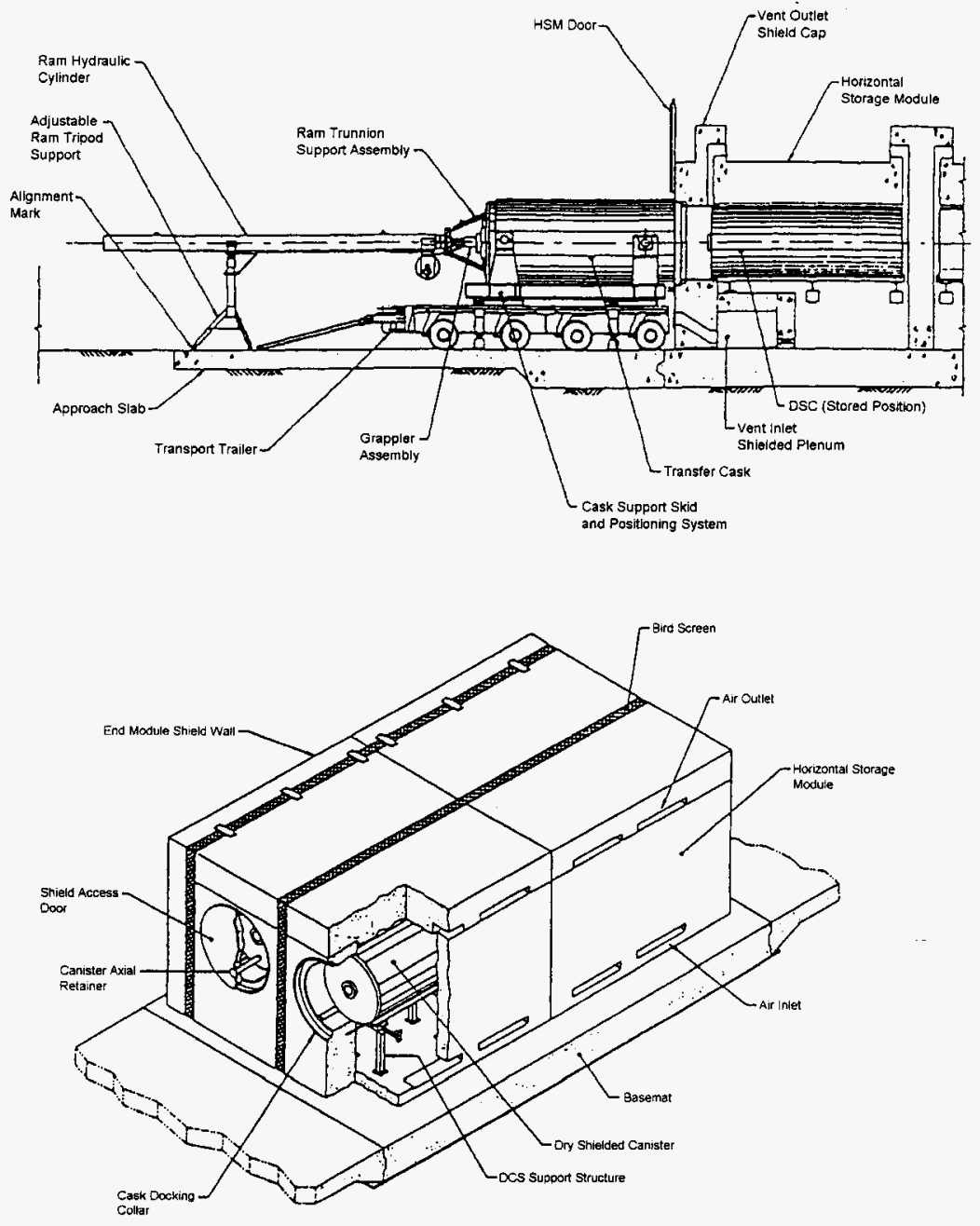
B.2.2.4 Advantages and Disadvantages. Advantages to the Nuhoms ${ }^{\circ}$ system are discussed in the following.

- The Nuhoms system is a proven technology with systems operating by Carolina Power and Light Company and Duke Power Company. Several units are also being purchased by DOE for storage of Three Mile Island fuel assemblies at the Idaho National Engineering Laboratory.

- Individual canisters, although provided with shielding, do not require their own individual shielding. During transfer, the cask into which the DSC is inserted provides the shielding and during storage, the HSM provides the shielding. This concept provides considerable economic benefit since as few as one transfer or transport cask is required.

- If desired, an offsite transportation cask (10 CFR 71) could be purchased instead of the onsite-only transfer cask to provide greater flexibility.

- Since the Nuhoms system comes with a road and/or rail transporter specifically designed for their transfer cask, they would not need to be procured separately.

- Only one heavy lift crane movement (rail to road transporter) would be required since the DSC is pushed horizontally from the transfer cask into the HSM using a Nuhoms supplied hydraulic ram.

Disadvantages to the Nuhoms" -24 system are discussed in the following.

- The standard Nuhoms" HSM is designed for a seismic, horizontal peak ground acceleration of $0.25 \mathrm{~g}$. Depending on the safety class, critical damping factor, site location, and frequency range of the facility, the HSM may require a custom design for location on the Hanford Site.

- The Nuhoms ${ }^{\circ}$ system requires an extensive collection of transfer equipment (transfer cask, loading ram, road and rail transporters) that, if purchased, would require an expenditure of up to $\$ 1$ million. This transfer equipment would probably have no other use at the Hanford Site unless other Nuhoms ${ }^{\circ}$ systems were procured.

- $\quad$ "The experience at the Oconee Plant (Duke Power) with the onsite transfer cask shows it to be somewhat labor intensive to load with doses of up to 1.2 rem personnel dose per transfer (Monthey and Bergsman 1994)."

B.2.2.5 Cost and Schedule Estimates. The cost for an individual PWR DSC is estimated to be $\$ 250,000$. The estimated purchase price for transfer equipment, including transfer cask, skid, lifting yoke, ramming system, and positioning trailer is less then \$1 million. Increase this to $\sim \$ 1.5$ million for a cask fabricated to meet $10 \mathrm{CFR} 71$ requirements. The estimated cost for the HSM is $\$ 125,000$ for each unit. The concrete storage pad needed for the HSMs is estimated to be $\$ 150,000$. Therefore, the cost for transfer (discussed in Section B.4) and storage of all 72 PWR-2 Shippingport fuel assemblies using Vectra's 
Nuhoms system is estimated to be $\$ 2.4$ million. This would increase the total cost for retrieval, transport, and storage of the fuel assemblies to $\$ 5.4$ million, including contingency. This total cost is summarized in Table B- 3 at the end of this appendix.

While there seems to be a considerable number of items to be completed before fuel transfers can start, including the construction of the HSM, all of these items can be address simultaneously. If a transfer cask needs to be fabricated, the total manufacturing schedule would be approximately one year. If the transfer equipment is to be leased, this manufacturing schedule can be reduced to six months. The actual transfer of the PWR-2 fuel assemblies from $T$ Plant to the interim storage area is estimated to take four months including one training cask and three loaded casks. A complete schedule of PWR-2 fuel assembly fuel retrieval using aboveground storage containers is shown in Figure B-5 at the end of this appendix.

\section{B.3 FUEL ASSEMBLY LOADING AT T PLANT}

The use of a commercial storage cask would require a similar retrieval process of the PWR-2 fuel assemblies from the T Plant storage pool as stated in Section 7.0. The PWR-2 fuel assemblies will be loaded dry into an open transfer cask within the railroad tunnel in a similar manner to the T Plant Canister loading mentioned in previous sections. The cask and basket lids would need to be removed and reinserted using the 45 ton bridge crane hoist and either manually bolted and/or welded. Both the VSC and the Nuhoms" systems can hold up to 24 PWR-2 fuel assemblies. The cask lid would need to be temporarily replaced on the cask during non-loading periods until loading can be completed. In addition, the fuel assemblies would also need to be vacuum dried, the basket lids welded shut, and the internal space inerted before leaving the T Plant tunnel.

\section{B.4 TRANSPORT FROM T PLANT TO INTERIM STORAGE AREA}

Because of the weight of the transfer and storage casks (greater than 100 tons). they are usually transported using rail for long distances and by specially built transporters for short distances. Primarily because of the high cost of improving the access road and ramp leading to the $T$ Plant railroad tunnel, it is recommended that a railroad truck be used for the initial loading and transport of the transfer cask. The use of rail transport would allow the cask to be transported to within a half mile of the 200 Area ISA or within $60 \mathrm{~m}$ $(200 \mathrm{ft})$ of the PFP storage area. The operations fee for use of a locomotive is $\$ 525 /$ hour. Each transfer is estimated to take one eight hour day.

The Nuhoms" system comes with specially designed railroad and/or road transporters. The Nuhoms ${ }^{\circ}$ transfer cask and cradle can be easily transferred between the two using a 150 to 200 ton heavy lift crane or the use of "jacking towers.' The Nuhoms" road transporter and ramming system is designed to mate with the HSMs and will allow the DSC to be transferred within the HSM unit without the use of a crane. 
Fig 8-5 PWR-2 FUEL ASSEMBLIES REMOVAL (STORAGE IN ABOVEGROUND STORAGE CASKS) Summary Schedule

\begin{tabular}{|c|c|c|c|c|c|c|c|c|c|c|c|c|c|c|c|c|c|c|c|}
\hline \multirow[b]{2}{*}{10} & \multirow{2}{*}{ Task Name } & \multirow[b]{2}{*}{ Days } & \multirow[b]{2}{*}{ Start } & \multicolumn{3}{|c|}{96} & \multicolumn{4}{|c|}{97} & \multicolumn{4}{|c|}{98} & \multicolumn{4}{|c|}{99} & \\
\hline & & & & 4 & 7 & 10 & \begin{tabular}{l|l}
1 & 1 \\
\end{tabular} & 4 & 7 & 10 & 1 & 4 & 7 & 10 & 1 & 4 & \begin{tabular}{l|l}
7 & 10 \\
\end{tabular} & 10 & \\
\hline 1 & Project Task Documentation & $248 d$ & $10 / 1 / 96$ & & & & & & & & & & & & & & & & \\
\hline 2 & Issue Project Task Authorization & 34d & $10 / 1 / 96$ & & & $\mathbf{E}$ & & & & & & & & $\vdots$ & & & & : & \\
\hline 3 & Produce Project QA Plan & 27d & $1 / 9 / 97$ & & & & ש & & & & & & & & & & & & \\
\hline 4 & Preliminary Hazards Analysis & $100 d$ & $1 / 2 / 97$ & & & & & & & & & & & & & & & & \\
\hline 5 & Fuel Assembly Characterization Report & $40 \mathrm{~d}$ & $5 / 23 / 97$ & & & & & & & & & & & & & & & & \\
\hline 6 & SNF Technical Data Package & $40 d$ & $7 / 17 / 97$ & & & & & & & : & & & & & & & & & \\
\hline 7 & Safety Basis Documentation & $517 \mathrm{~d}$ & $1 / 2 / 97$ & & & & & & & & & & & & & & & & \\
\hline 8 & T Plant ISB (Addendum) & $517 d$ & $1 / 2 / 97$ & & & & & & & & & & & & & & & & \\
\hline 9 & SARP (Addendum) & 517d & $1 / 2 / 97$ & & & & & & & & & & & & & & & & \\
\hline 10 & CSB SAR (Addendum) & $547 d$ & $1 / 2 / 97$ & & & & & & & & & & & & & & & & \\
\hline 11 & Criticality Evaluation & $205 d$ & $1 / 2 / 97$ & & & & & & & & & & & & & & & & \\
\hline 12 & ALARA Plan & 205d & $1 / 2 / 97$ & & & & & & & & & & & & & & & : & \\
\hline 13 & Environmental Compliance Documentation & $175 d$ & $1 / 2 / 97$ & & & & & & & & & & & & & & & & \\
\hline 14 & Environmental Assessment & $175 d$ & $1 / 2 / 97$ & & & & & & & & & & & & & & & $\vdots$ & \\
\hline 15 & CSB Notice of Construction & $130 d$ & $1 / 2 / 97$ & & & & & & & & & & & & & & & & \\
\hline 16 & Cultural Resources Review & $10 \mathrm{~d}$ & $1 / 2 / 97$ & & & - & & & & & & & & & & & & & \\
\hline 17 & New Equipment (Design, Build, Test) & $200 d$ & $3 / 31 / 97$ & & & & & & & & & & & & & & & & \\
\hline 18 & Primary and Secondary Grapplers & 200d & $3 / 31 / 97$ & & & & & & & & & & & & & & & & \\
\hline 19 & 3-Ton Hoist & $175 d$ & $3 / 31 / 97$ & & & & & & & & & & & & & & & & \\
\hline 20 & Cask Lid Grappler & $60 d$ & $3 / 31 / 97$ & & & & & & & & & & & & & & & & \\
\hline 21 & Grappler Stand & 200d & $3 / 31 / 97$ & & & & & & & & & & & & & & & & \\
\hline 22 & Basket Lid Grappler & 60d & $3 / 31 / 97$ & & & & & & & & & & & & & & & & \\
\hline 23 & Storage Cask/Module & $200 d$ & $3 / 31 / 97$ & & & & & & & & & & & & & & & & \\
\hline 24 & Fuel Assembly Storage Canister & 2000 & $3 / 31 / 97$ & & & & & & & & & & & & & & & & \\
\hline 25 & Storage Pad & $200 d$ & $3 / 31 / 97$ & & & & & & & & & & & & & & & & \\
\hline 26 & Transport Route/Equipment & 261d & $10 / 16 / 98$ & & & & & & & & & & & & & & & & \\
\hline 27 & Transport Cask \& Equipment (Leased) & 2610 & $10 / 16 / 98$ & & & & & & & & & & & & & & & & \\
\hline 28 & Railroad Locomotive Rental (Periodic) & 261d & $10 / 16 / 98$ & & & & & & & & & & & & & & & & \\
\hline 29 & Prep. of Operational Documentation & 190d & $1 / 2 / 98$ & & & & & & & & & & & & & & & & \\
\hline 30 & Training Manuals & $100 \mathrm{~d}$ & $1 / 2 / 98$ & & & & & & & & & & & & & & & & \\
\hline 31 & Operational Procedures & $190 \mathrm{~d}$ & $1 / 2 / 98$ & & & & & & & & & & & & & & & & \\
\hline 32 & Health Physics Procedures & 20d & $1 / 2 / 98$ & & & & & & & - & & & & & & & & & \\
\hline 33 & Start-up Activities & 291d & $5 / 1 / 98$ & & & & & & & & & & & & & & & & \\
\hline 34 & ....Start-up Documentation (ATP) & $120 d$ & $5 / 1 / 98$ & & & & & & & & & & & & & & - & & \\
\hline 35 & Manufacture Simulated Fuel Assemblies & 90d & $5 / 1 / 98$ & & & & & & & & & & & & & & & & \\
\hline 36 & Start-up testing (Non-Radioactive) & $30 \mathrm{~d}$ & $10 / 16 / 98$ & & & & & & & & & & $=$ & & & & & & \\
\hline 37 & T Plant Training & $20 d$ & $12 / 21 / 98$ & & & & & & & & & & & $\cdot$ & & & & & \\
\hline 38 & 200 ton Crane $\&$ Road Transp. Training & tod & $1 / 15 / 99$ & & & & & & & & & & & . & & & & 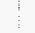 & \\
\hline 39 & Operational Readiness Review (ORR) & $30 d$ & $1 / 28 / 99$ & & & & & & & & & & & & $=$ & & & & \\
\hline 40 & Start-up (Fill First Cask) & $30 \mathrm{~d}$ & $5 / 3 / 99$ & & & & & & & & & & & & & 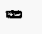 & & & \\
\hline 41 & SNF Removal Activities & $90 d$ & $6 / 14 / 99$ & & & & & & & & & & & & & & & & \\
\hline 42 & Operations at T Plant & 90d & $6 / 14 / 99$ & & & & & & & & & & & & & & 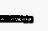 & & \\
\hline 43 & Transportation to Storage Pad & $90 d$ & $6 / 14 / 99$ & & & & & & & & & & & & & & & 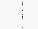 & \\
\hline 44 & Operations at Storage Pad & $90 d$ & $6 / 14 / 99$ & & & & & & & & & & & & & & & & \\
\hline 45 & D\&D Activities & 40d & $11 / 1 / 99$ & & & & & & & & & & & & & & & & \\
\hline 46 & Remove Pool Water from T Plant & $40 d$ & $11 / 1 / 99$ & & & & & & & & & & & $\vdots$ & & & & - & \\
\hline 47 & Remove Ion Exchange Column & $40 d$ & $11 / 1 / 99$ & & & & & & & & & & & & & & & שמ & \\
\hline 48 & Task Complete & od & $12 / 24 / 99$ & & & & & & & & & & & & & & & $\bullet$ & \\
\hline
\end{tabular}


Sierra Nuclear's VCC or transfer cask would require a modified railroad car for loading in T Plant and transfer to the storage site vicinity. From there it would need to be transferred from the railroad car to a road transporter using a heavy lift crane. Once the cask has been transported to the concrete storage pad, it would again need to be transferred from the road transporter to the pad using a heavy lift crane.

Neil F. Lampson was contacted concerning the rental of heavy lift cranes and the use of their Goldhofer transporter. They recommended the use of a 200 ton crane for the transfer of $120+$ ton casks. The monthly rental of this type of crane is $\$ 13,000 / \mathrm{month}$ with initial assembly and final disassembly charges of $\$ 17,000$ each. If small, assist cranes are required for assembly or disassembly, they would cost $\$ 3,500 /$ day. Short, interim transfers of the crane within the Hanford Site were estimated to cost $\$ 12,000$ per assembly or disassembly. The crane requires three personnel loperator, oiler, and flagger) to operate with an hourly rate of $\$ 65$. The Goldhofer transporter and tractor rental is $\$ 20,000 /$ month and requires five personnel to operate, again at $\$ 65 /$ hour/person.

Lampson may need to provide some engineering support for any required modifications to the transporter to transport the casks. This service would be at $\$ 75 /$ hour/person. All operators would require one day for training and to complete badging requirements at a cost of $\$ 50 /$ hour/person.

\section{B.5 OFFSITE TRANSPORT AND REPOSITORY ACCEPTANCE REQUIREMENTS}

Although all the storage cask systems listed in Table B-1 meet the 10 CFR 72 requirements for storage, only some of them have a transportation cask that meets the 10 CFR 71 requirements for offsite transport. The Nuhoms system has an approved transportation cask and transporter for an additional expense. The VSC system can only be used for onsite storage and transfer. However, since initially the casks will only need to be transported within the Hanford Site, there is no need to meet the 10 CFR 71 requirements. But, in the future the fuel assemblies will need to be transported offsite to the national repository for permanent disposal. The chosen storage cask will need to have its SNF off-loaded and transferred to an approved transport cask. Both the Nuhoms and the VSC systems are equipped with a removable storage container or basket that will promote ease of transferal to a transportation cask.

The acceptance requirements for receipt of SNF at the proposed high-level national repository at Yucca Mountain have not been defined. The requirements will probably include storage container dimensions, dose rates, heat rates, and radionuclide content. Except for storage container dimensions, it is assumed that the PWR-2 fuel assemblies will fall within acceptance requirements because of its similarity to commercial SNF. Since the acceptance requirements are unknown, the SNF may need to be off-loaded and placed into an appropriate container for repository storage. This transferal may be performed at the Hanford Site or at the national repository. 
TABLE B-2. PWR-2 FUEL ASSEMBLIES REMOVAL FROM T PLANT COST ESTIMATE - VSC STORAGE

\begin{tabular}{|c|c|c|c|c|c|c|c|c|}
\hline PROJECT ACTIVITIES & $\begin{array}{l}\text { Duration } \\
\text { (Days) }\end{array}$ & FTE & $\begin{array}{c}\text { Trade } \\
\text { Indicator }\end{array}$ & Labor & Material & $\begin{array}{c}\text { Total } \\
\text { Estimated } \\
\text { Cost }\end{array}$ & $\begin{array}{c}\text { Contingency } \\
\text { Variation }\end{array}$ & $\begin{array}{l}\text { High End } \\
\text { Cost } \\
\text { For Item }\end{array}$ \\
\hline & & & & & & & & \\
\hline PROJECT DOCUMENTATION & & 0.0 & & $\$ 0$ & $\$ 0$ & $\$ 30,000$ & & $\$ 33,000$ \\
\hline & & & & & & & & \\
\hline SAFETY BASIS DOCUMENTATION & & 0.0 & & $\$ 0$ & $\$ 0$ & $\$ 265,000$ & & $\$ 397,500$ \\
\hline & & & & & & & & \\
\hline ENVIRONMENTAL COMPLIANCE & & 0.0 & & $\$ 0$ & $\$ 0$ & $\$ 102,000$ & & $\$ 152,200$ \\
\hline & & & & & & & & \\
\hline PREP. OF OPERATIONAL DOCUMENTS & & 4.0 & & $\$ 109,054$ & $\$ 3,000$ & $\$ 112,054$ & & $\$ 134,465$ \\
\hline FUEL ASSEMBLY CHARACTERIZATION & & 0.0 & & $\$ 0$ & $\$ 0$ & $\$ 100,000$ & & $\$ 120,000$ \\
\hline & & & & & & & & \\
\hline NEW EQUIPMENT & & 4.0 & & $\$ 32,451$ & $\$ 1,551,000$ & $\$ 1,769,451$ & & $\$ 2,050,019$ \\
\hline & & & & & & & & \\
\hline START-UP ACTIVITIES & & 66.0 & & $\$ 509,328$ & $\$ 4,240$ & $\$ 523,568$ & & $\$ 583,317$ \\
\hline TRANSPORT ROUTE/EOUIIPMENT & & & & m & & & & \\
\hline & & 0.0 & & $\$ 0$ & $\$ 644,000$ & $\$ 644,000$ & & $\$ 728,400$ \\
\hline SNF REMOVAL ACTIVITIES & & 30.0 & & $\$ 621,692$ & $\$ 52,200$ & $\$ 673,892$ & & $\$ 798,854$ \\
\hline & & & & & & & & \\
\hline DECOMMISSIONING ACTIVITIES & & 19.0 & & $\$ 47,948$ & $\$ 5,040$ & $\$ 120,988$ & & $\$ 143,578$ \\
\hline & & & & & & & & \\
\hline TOTAL & & 123.0 & & $\$ 1,320,474$ & $\$ 2,259,480$ & $\$ 4,340,954$ & & $\$ 5,141,333$ \\
\hline TOTAL ESTIMATED COST & & & & & & $\$ 4,340,954$ & & \\
\hline TOTAL HIGH END COST & & & & & & & $( + ) \longdiv { 1 8 \% }$ & $\$ 5,141,333$ \\
\hline
\end{tabular}

TOTAL ESTIMATED COST IS ASSUMED TO BE THE INDICATED HIGH END COST. THIS IS THE NOMINAL COST PLUS A $18 \%$ CONTINGENCY ALLOWANCE FOR PROJECT UNCERTAINTIES.

NOTES:

- Fully Burdened Labor Rates in FY96 Dollars

Exempt - $\$ 52.43$

Bargaining Unit - $\$ 48.29$

Offsite Contractors - $\$ 65.00$

- Dollars have NOT been escalated for outyears. 
TABLE B-3. PWR-2 FUEL ASSEMBLIES REMOVAL FROM T PLANT COST ESTIMATE - NUHOMS STORAGE

\begin{tabular}{|c|c|c|c|c|c|c|c|c|}
\hline PROJECT ACTIVITIES & $\begin{array}{l}\text { Duration } \\
\text { (Days) }\end{array}$ & FTE & $\begin{array}{c}\text { Trade } \\
\text { Indicator }\end{array}$ & Labor & Material & $\begin{array}{c}\text { Total } \\
\text { Estimated } \\
\text { Cost }\end{array}$ & $\begin{array}{c}\text { Contingency } \\
\text { Variation }\end{array}$ & $\begin{array}{l}\text { High End } \\
\text { Cost } \\
\text { For ltem }\end{array}$ \\
\hline & & & & & & & & \\
\hline PROJECT DOCUMENTATION & & 0.0 & & $\$ 0$ & $\$ 0$ & $\$ 30,000$ & & $\$ 33,000$ \\
\hline SAFETY BASIS DOCUMENTATION & & 00 & & & & & & \\
\hline SAFEIY BASIS DOCUMENIATION & & 0.0 & & $\$ 0$ & $\$ 0$ & $\$ 265,000$ & & $\$ 397,500$ \\
\hline & & & & & & & & \\
\hline ENVIRONMENTAL COMPLIANCE & & 0.0 & & $\$ 0$ & $\$ 0$ & $\$ 102,000$ & & $\$ 152,200$ \\
\hline PREP. OF OPERATIONAL DOCU. & & 40 & & & & & & \\
\hline & & & & & $\$ 3,000$ & $\$ 112,054$ & & $\$ 134,465$ \\
\hline FUEL ASSEMBLY CHARACTERIZATION & & 0.0 & & $\$ 0$ & $\$ 0$ & $\$ 100,000$ & & $\$ 120,000$ \\
\hline 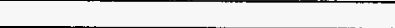 & & & & & & & & \\
\hline NEW EQUIPMENT & & 4.0 & & $\$ 32,451$ & $\$ 1,296,000$ & $\$ 1,514,451$ & & $\$ 1,789,519$ \\
\hline & & & & & & & & \\
\hline START-UP ACTIVITIES & & 57.0 & & $\$ 497,888$ & $\$ 4,240$ & $\$ 512,128$ & & $\$ 570,733$ \\
\hline & & & & & & & & \\
\hline TRANSPORT ROUTE/EQUIPMENT & & 0.0 & & $\$ 0$ & $\$ 1,167,500$ & $\$ 1,167,500$ & & $\$ 1,304,250$ \\
\hline & & & & 9507070 & 450 & & & \\
\hline SNF REMOVAL ACTIVITIES & & 21.0 & & $\$ 587,372$ & $\$ 52,200$ & $\$ 639.572$ & & $\$ 761,102$ \\
\hline DECOMMISSIONING ACTIVITIES & & 19.0 & & $\$ 47,948$ & $\$ 5,040$ & $\$ 120,988$ & & $\$ 143,578$ \\
\hline & & & & & & & & \\
\hline TOTAL & & 105.0 & & $\$ 1,274,714$ & $\$ 2,527,980$ & $\$ 4,563,694$ & & $\$ 5,406,347$ \\
\hline TOTAL ESTIMATED COST & & & & & & $\$ 4,563,694$ & & \\
\hline TOTAL HIGH END COST & & & & & & & $(+) 18 \%$ & $\$ 5,406,347$ \\
\hline
\end{tabular}

TOTAL ESTIMATED COST IS ASSUMED TO BE THE INDICATED HIGH END COST. THIS IS THE NOMINAL COST PLUS A $18 \%$ CONTINGENCY ALLOWANCE FOR PROJECT UNCERTAINTIES.

NOTES:

Fully Burdened Labor Rates in FY96 Dollars

Exempt - $\$ 52.43$

Bargaining Unit - $\$ 48.29$

Offsite Contractors - $\$ 65.00$

Dollars have NOT been escalated for outyears. 


\section{APPENDIX C}

SAFETY BASIS FOR INTERIM CASK STORAGE

C-1 


\section{CONTENTS}

C.0 SAFETY BASIS FOR INTERIM CASK STORAGE $\ldots \ldots \ldots \ldots \ldots \ldots \ldots \ldots$

C. 1 T PLANT OPERATIONS SAFETY ANALYSIS $\ldots \ldots \ldots \ldots \ldots \ldots \ldots \ldots \ldots$

C. 2 TRANSPORTATION OPERATIONS SAFETY ANALYSIS $\ldots \ldots \ldots \ldots \ldots \ldots \ldots . . . . .$.

C.3 INTERIM STORAGE OPERATIONS SAFETY ANALYSIS

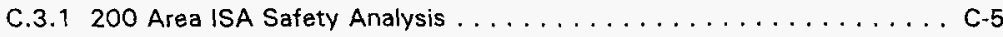

C.3.2 PFP Storage Area Safety Analysis . . . . . . . . . . . . . C-5 


\section{C.0 SAFETY BASIS FOR INTERIM CASK STORAGE}

This appendix identifies the safety documentation requirements for the cask storage of PWR-2 fuel assemblies described in Appendix B. It estimates the costs and timescale for the production of safety documentation required for T Plant operations. However, the cost of safety documentation for transportation and CSB operations are not part of the scope of this appendix. The information presented is based on Section 9.0 which discusses the primary safety basis alternatives for the preferred storage option within the CSB.

The transfer of the PWR-2 fuel assemblies from T Plant to an aboveground interim storage location has been divided into the following three sequential operational phases.

1. T Plant operations

2. Transportation operation

3. Interim storage operations

Safety analysis, to the extent needed, will be separately performed for each of these phases. The safety analysis process will start with a USO evaluation. If it is determined that a USO does not exist, the safety analysis required might only be that required to support the USO evaluation. If it is determined that a USQ does exist, an amendment package to the safety authorization basis documentation will be required that covers all the necessary safety analysis required to obtain DOE approval.

In this appendix, each of the three operational phases are assessed to estimate the safety analysis required and an estimates is made for the cost and time required to perform the T Plant analysis and produce safety documentation.

\section{C.1 T PLANT OPERATIONS SAFETY ANALYSIS}

The current SABD for T Plant does not cover removal of the PWR-2 fuel assemblies from the water pool in which they are presently stored. The interim storage option of cask storage, will require the removal of the PWR-2 fuel assemblies from the water pool. The USO evaluation of this option will show that a USO exists for the T Plant operation. This will result in the need for the preparation of an amendment package to the current SABD.

The primary safety analysis documentation for $T$ Plant is identified in Section 9.1. From a safety analysis standpoint, the option being considered here involves essentially the same operations in T Plant, (i.e., fuel assembly removal from the pool and placement into a cask located in an adjacent cell) as the CSB storage option described in section 7 . The safety analysis requirements will thus be similar. T Plant operational differences related to the two options that could potentially necessitate changes in the primary safety analysis requirements to assure coverage by secondary storage safety analysis include:

1. The capacity (and related design differences) of the transportation cask.

2. The mode of transportation on which the cask is located.

3. The design of the cask seal. 
For the CSB storage vault option, the same cask used to transport the $\mathrm{K}$ Basin spent nuclear fuel to the CSB would be used for transporting the PWR-2 fuel assemblies. This cask can accommodate four fuel assemblies. For the cask storage option, typical NRC approved casks would be used that can hold up to 24 PWR fuel assemblies. In either case, however, the basic operations in T Plant will be essentially the same and the potential bounding accidents would also likely be the same. Thus, the T Plant safety analysis requirements identified in Section 9.0 are applicable to cask storage and no change in the requirements is expected as a result of this difference.

Because of the differences in the cask weights, cask storage may have to use a rail car to carry the cask in and out of the T Plant. For CSB vault storage, the use of a road transporter is planned exclusively. This difference has no impact on the T Plant safety analysis requirements. Thus, the applicability of CSB vault storage requirements to aboveground cask storage will not change as a result of this difference.

In both options, operations could potentially involve personnel reentering the loading area to complete the cask seal. In both cases it is assumed that insertion of shield plugs associated with the transportation package will reduce the radiation dose rates to acceptable levels. Acceptable levels will be confirmed before reentry (see Section 7.1.8.). The difference in the cask sealing operation for the two options is not expected to impact the safety analysis requirements. Thus, the applicability of CSB storage requirements to cask storage will not change as a result of this difference.

Based on the above discussions, it is expected that the same safety analysis requirements will apply to both CSB and cask storage. Consequently, the estimated cost and time required to prepare the SABD amendment package for aboveground cask storage is expected to remain the same as for CSB storage. These estimates are:

1. Amendment Package Preparation Cost: $\$ 110,000$.

2. Elapsed Time to Complete Document: five months.

3. Time for DOE approval: three months.

The schedule will remain the same as for CSB storage.

\section{C.2 TRANSPORTATION OPERATIONS SAFETY ANALYSIS}

The transportation safety analysis requirements (TSAR) for both CSB vault storage and cask storage are expected to be essentially the same. Both options will be using a transport cask that has been approved for transporting SNF at Hanford. For CSB storage, the use of the K Basin SNF transport cask with a modified K Basin MCO is planned. For cask storage, the typical commercially available casks being considered include:

1. The VSC System produced by the Sierra Nuclear Corporation; and

2. The Nuhoms Dry Storage/Transfer System produced by Vectra, Incorporated.

These casks will have a TSAR, will have met the requirements for onsite transport, and will have received an NRC Certificate of Compliance. These casks will have an internal basket capable of holding 24 standard PWR assemblies and can comfortably accommodate the PWR-2 fuel assemblies. 
Since there are only 72 PWR-2 fuel assemblies, only three trips will be required (versus 18 trips for CSB storage). For both options, a SARP will be required to show that the transportation operation is safe for the PWR-2 content and for conditions specific to the Hanford Site.

The CSB storage option safety analysis to be included in the SARP is identified in Section 9.1.4.2. It is expected that similar analysis will be required for cask storage. The major operational difference will be the likely requirement in cask storage to offload the transport cask from a rail car to a road transporter. In addition to the safety analysis requirements identified for CSB storage, the off-loading operation will require additional tiedown analysis.

\section{C.3 INTERIM STORAGE OPERATIONS SAFETY ANALYSIS}

The following two locations are considered for aboveground cask storage:

1. 200 Area ISA next to the CSB; and

2. PFP pad storage within the protected area.

\section{C.3.1 200 Area ISA Safety Analysis.}

A 200 Area ISA is presently planned for storing Category IV-D SNF. The ISA will probably be contiguous to the CSB. According to McCormack (1996), SNF addressed to be stored in casks at the 200 Area ISA will include:

1. FFTF Category IV-E SNF;

2. Neutron Radiography Facility TRIGA SNF;

3. 200 Area Low Level Burial Grounds TRIGA SNF; and

4. 300 Area Light Water Reactor SNF.

The safety analysis required for the 200 Area ISA will likely be in the form of an amendment to the CSB SAR. This would be performed for the SNF listed previously above. If cask storage is implemented and the 200 Area ISA is chosen as the location, the most effective and efficient course for preparing the safety analysis documentation is to add the PWR-2 SNF to those listed and make it part of the amendment package planned for these materials.

\section{C.3.2 PFP Storage Area Safety Analysis}

Considering physical protection requirements, the PWR-2 fuel assemblies will decay to lower radiation levels by about 2004, changing them from Category IV to Category II. Since the 200 Area ISA is not currently intended for use as a Category II storage site, the PFP protected area, which qualifies as a Category II storage location, is being considered as a contingency site for storing the PWR-2 fuel assemblies. The PFP is currently storing LAMPRE SNF and plans to store eight casks containing slightly irradiated non-Category IV FFTF SNF. 
A USO evaluation performed by PFP personnel concluded that a USO did not exist for storing FFTF SNF at the PFP. In support of this USO was as assessment showing that the FFTF SNF loaded storage cask meets safe storage requirements. Changes to the PFP SAR are planned during the normal yearly SAR update. From discussions with PFP personnel, it is expected that a USO evaluation of the storage of the PWR-2 loaded casks at the PFP will also conclude that a USQ does not exist. Most of the necessary support to the USQ will be available in the cask TSAR, an NRC document that provides the basis for $N R C$ approval of the storage cask and shows the cask meets 10 CFR 72 requirements. In addition, site specific support analyses might be needed that include a criticality assessment since the PWR-2 casks will probably be located in close proximity to the FFTF casks. Site specific analysis might also address the ALARA aspects of the storage and any safety impact the storage may have on PFP safety. Amendment to the PFP SAR for the PWR-2 storage would be accomplished during the SAR yearly update. 


\section{APPENDIX D}

\section{DRAWING LIST}

D-1 


\section{D.0 DRAWING LIST}

\begin{tabular}{|c|c|c|c|}
\hline $\begin{array}{l}\text { Drawing } \\
\text { Number }\end{array}$ & Drawing Title & Sheet & Date \\
\hline $911 \mathrm{~B} 241$ & Bolt - Fuel Assembly PWR-2 & 1 & 1963 \\
\hline $971 \mathrm{~F} 381$ & $\begin{array}{l}\text { Bottom Extension Bracket - Blanket PWR-2 Product } \\
\text { Dwg. }\end{array}$ & 1 & 1961 \\
\hline $911 \mathrm{~F} 381$ & $\begin{array}{l}\text { Bottom Extension Bracket - Blanket PWR-2 Product } \\
\text { Dwg. }\end{array}$ & 2 & 1961 \\
\hline $911 F 888$ & $\begin{array}{l}\text { Top Extension Bracket - Blanket PWR-2 Product } \\
\text { Drawing }\end{array}$ & 1 & 1963 \\
\hline $911 \mathrm{~F} 888$ & $\begin{array}{l}\text { Top Extension Bracket - Blanket PWR-2 Product } \\
\text { Drawing }\end{array}$ & 2 & 1963 \\
\hline $911 \mathrm{~F} 888$ & $\begin{array}{l}\text { Top Extension Bracket - Blanket PWR-2 Product } \\
\text { Drawing }\end{array}$ & 3 & 1963 \\
\hline $916 \mathrm{~F} 902$ & PWR-2 Fluxwell Blanket Ass'Y Assembly Dwg. & 1 & 1963 \\
\hline $916 \mathrm{F902}$ & PWR-2 Fluxwell Blanket Assembly Dwg. & 2 & 1963 \\
\hline $916 \mathrm{~F} 902$ & PWR-2 Fluxwell Blanket Assembly Dwg. & 3 & 1963 \\
\hline $918 \mathrm{~F} 509$ & $\begin{array}{l}\text { PWR-2 Blanket Assembly Modification Top Extension } \\
\text { Bracket }\end{array}$ & 1 & 1963 \\
\hline $918 \mathrm{~F} 509$ & $\begin{array}{l}\text { PWR-2 Blanket Assembly Modification Top Extension } \\
\text { Bracket }\end{array}$ & 2 & 1963 \\
\hline $921 J 962$ & Blanket Fuel Assemblies PWR 2 & 1 & 1963 \\
\hline $921 \mathrm{~J} 962$ & Blanket Fuel Assemblies PWR 2 & 2 & 1963 \\
\hline $921 J 987$ & PWR-2 Blanket Fuel Cluster Product Drawing & 1 & 1963 \\
\hline $921 J 987$ & PWR-2 Blanket Fuel Cluster Product Drawing & 2 & 1963 \\
\hline $922 \mathrm{~F} 432$ & $\begin{array}{l}\text { PWR-2 Blanket Assembly Modification Variable Orifice } \\
\text { Unit }\end{array}$ & 1 & 1963 \\
\hline $922 \mathrm{~F} 432$ & $\begin{array}{l}\text { PWR-2 Blanket Assembly Modification Variable Orifice } \\
\text { Unit }\end{array}$ & 2 & 1963 \\
\hline$H-1-81534$ & $\begin{array}{l}\text { TN-WHC Cask Transportation System Assembly } \\
\text { Drawing }\end{array}$ & - & 1996 \\
\hline H-1-81535 & $\begin{array}{l}\text { TN-WHC Cask Transportation System Assembly and } \\
\text { Parts List }\end{array}$ & 1 & 1996 \\
\hline$H-1-81535$ & $\begin{array}{l}\text { TN-WHC Cask Transportation System Assembly and } \\
\text { Parts List }\end{array}$ & 2 & 1996 \\
\hline$H-1-81535$ & TN-WHC Cask Transportation System Lid & 4 & 1996 \\
\hline$H-1-81555$ & $\begin{array}{l}\text { Approx. Weights \& Dimensions for TN-WHC K Basin } \\
\text { Cask Transport Trailer Concept Design }\end{array}$ & 1 & 1996 \\
\hline$H-2-32990$ & Hook Clearance Bridge Crane & 1 & 1962 \\
\hline $\mathrm{H}-2-70818$ & $\begin{array}{l}\text { Piping Arrangement Plan, Section \& Elevation for Ion } \\
\text { Exchange System }\end{array}$ & 1 & 1977 \\
\hline$H-2-70819$ & Ion Exchange Colurnn & - & 1977 \\
\hline
\end{tabular}




\begin{tabular}{|c|c|c|c|}
\hline $\begin{array}{l}\text { Drawing } \\
\text { Number }\end{array}$ & Drawing Title & Sheet & Date \\
\hline $\mathrm{H}-2-70820$ & Ion Exchange System Handling Tools and Equipment & + & 1977 \\
\hline $\mathrm{H}-2-71233$ & PWR-2 Grappler Assembly & 1 & 1977 \\
\hline $\mathrm{H}-2-71233$ & PWR-2 Grappler Details & 2 & 1977 \\
\hline $\mathrm{H}-2-71233$ & PWR-2 Grappler Details & 3 & 1977 \\
\hline $\mathrm{H}-2-71233$ & PWR-2 Grappler Details & 4 & 1977 \\
\hline $\mathrm{H}-2-71234$ & PWR 2 Grappler Uncoupling Tool Assembly \& Details & 1 & 1977 \\
\hline $\mathrm{H}-2-72447$ & PWR-2 Core Blank Test Calibration & 1 & 1978 \\
\hline $\mathrm{H}-2-72876$ & PWR Core 2 Blanket Storage Rack M-160 Cask & 1 & 1978 \\
\hline $\mathrm{H}-2-72963$ & Auxiliary Grappler Assembiy \& Details & 1 & 1978 \\
\hline $\mathrm{H}-2-72963$ & Auxiliary Grappler Assembly \& Details & 2 & 1978 \\
\hline$H-2-74620$ & Auxiliary Grappler Assembly \& Details M-160 & 1 & 1978 \\
\hline$H-2-74620$ & Auxiliary Grappler Assembly \& Details M-160 & 2 & 1978 \\
\hline $\mathrm{H}-2-74620$ & Auxiliary Grappler Assembly \& Details M-160 & 3 & 1978 \\
\hline$H-2-826303$ & MCO Shell Assembly & 2 & $1995 ?$ \\
\hline $\mathrm{H}-2-826303$ & $\begin{array}{l}\text { MCO Bottom Conditioning Chamber Assembly and } \\
\text { View }\end{array}$ & 3 & $1995 ?$ \\
\hline $\mathrm{H}-2-826303$ & MCO Shell Assembly Alternative Fabrication & 4 & $1995 ?$ \\
\hline $\mathrm{H}-2-826303$ & MCO Shield Plug Assembly Plan View & 5 & $1995 ?$ \\
\hline $\mathrm{H}-2-826303$ & $\begin{array}{l}\text { MCO Shield Plug Assembly Sections, Views, Quick } \\
\text { Connectors \& Grapple Pocket }\end{array}$ & 6 & $1995 ?$ \\
\hline $\mathrm{H}-2-826303$ & $\begin{array}{l}\text { MCO Shield Plug Assembly Section and Views } \\
\text { (Rupture Disk \& HEPA Filter) }\end{array}$ & 7 & $1995 ?$ \\
\hline$H-1-X X X X X X$ & Multi Canister Overpack General Assembly & 2 & 1996 \\
\hline$H-1-X X X X X X$ & Multi Canister Overpack Canister Assembly \& Details & 3 & 1996 \\
\hline$H-1-X X X X X X$ & Multi Canister Overpack Plug Assembly \& Details & 4 & 1996 \\
\hline$H-1-X X X X X X$ & Multi Canister Overpack Draw Tube Assy \& Details & 5 & 1996 \\
\hline$H-1-X X X X X X$ & Multi Canister Overpack Details & 6 & 1996 \\
\hline $\mathrm{H}-2-88633$ & Structural Concrete Sect $1 \& 2$, Tunnel Detail & 8 & 1994 \\
\hline $\mathrm{H}-2-88633$ & Structural Concrete Sect $1 \& 2$, Tunnel Detail & 12 & 1994 \\
\hline
\end{tabular}


This page intentionally left blank. 


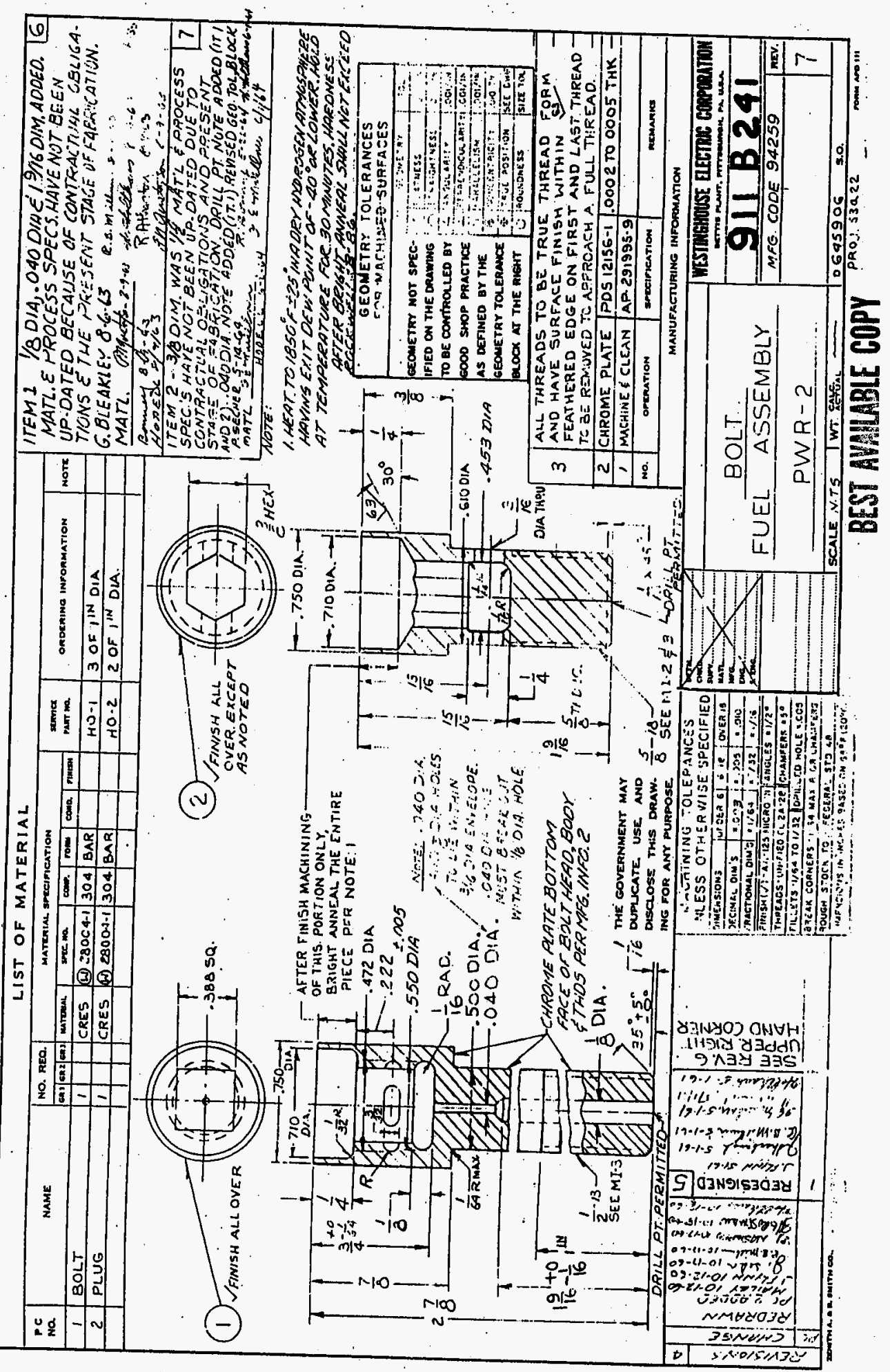


THIS PAGE INTENTIONALLY

LEFT BLANK 


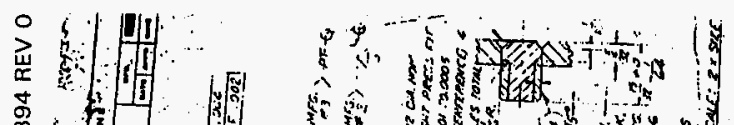

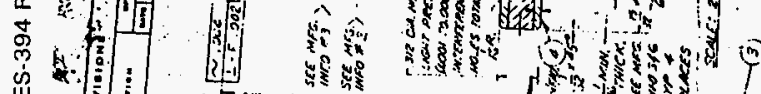

(a)

on

: 1

s

14 (1)

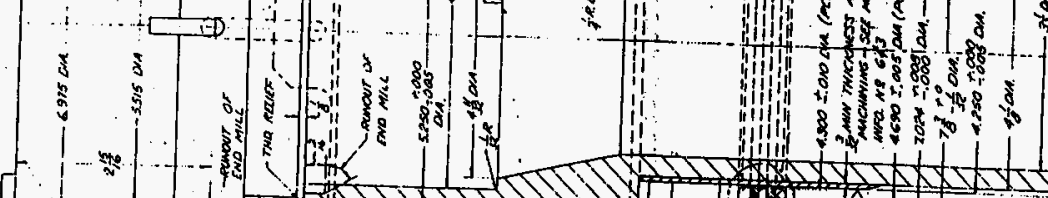

(2)

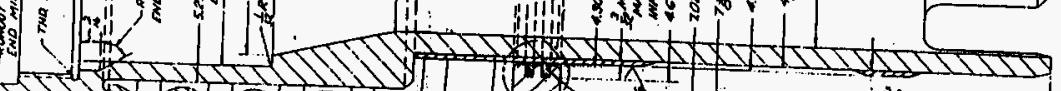

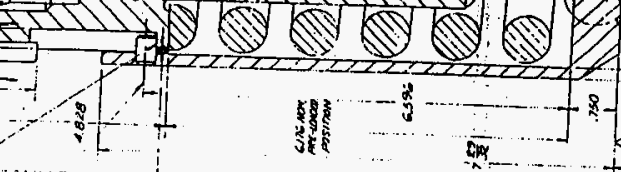

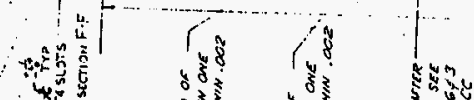

$2+\frac{1}{4}$

$r+4$

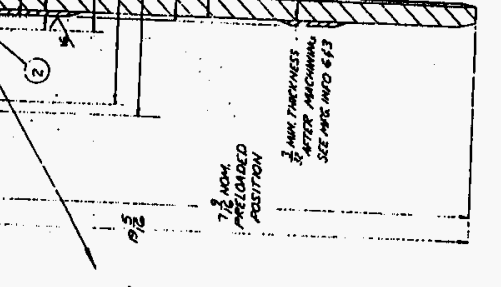

密

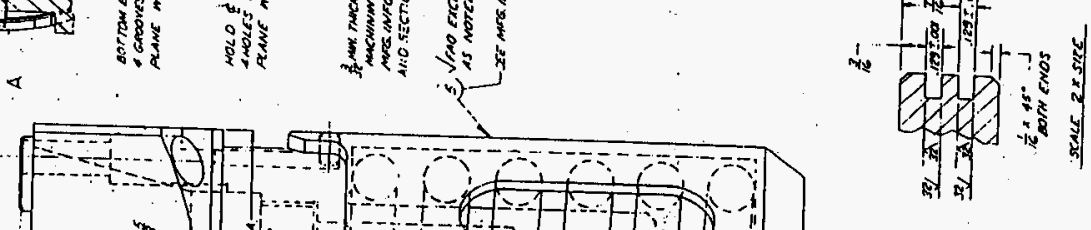

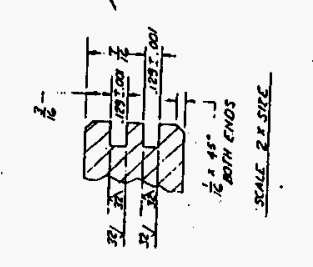

읭
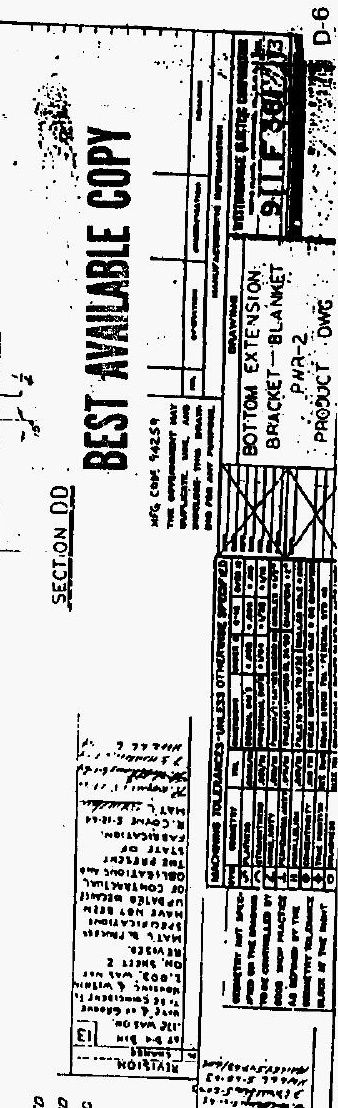

i

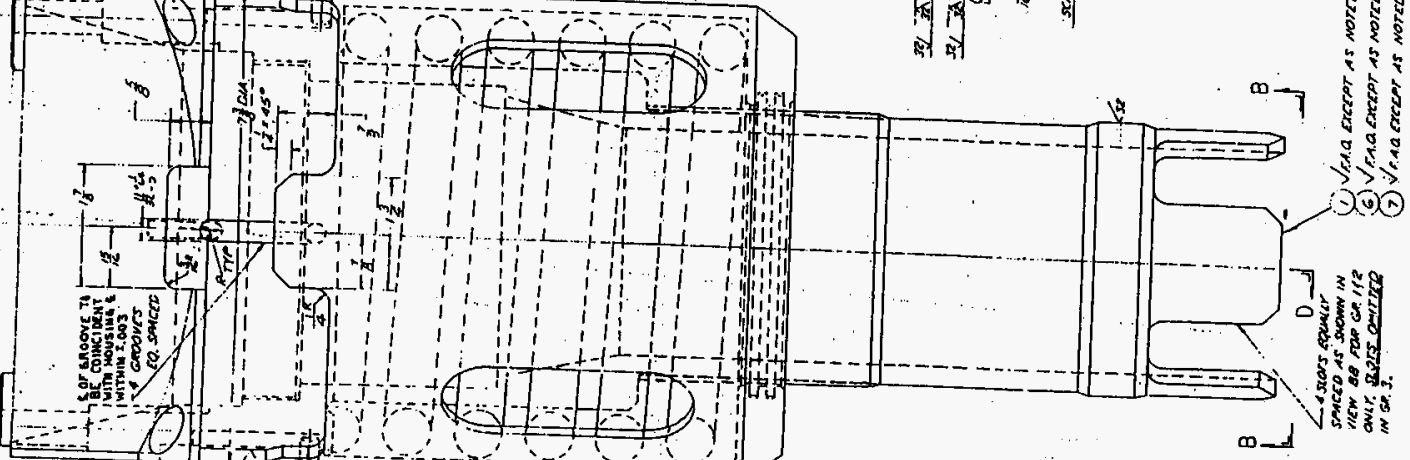
L.

का

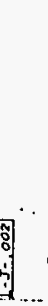

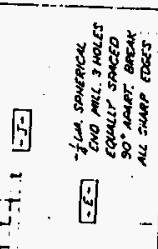
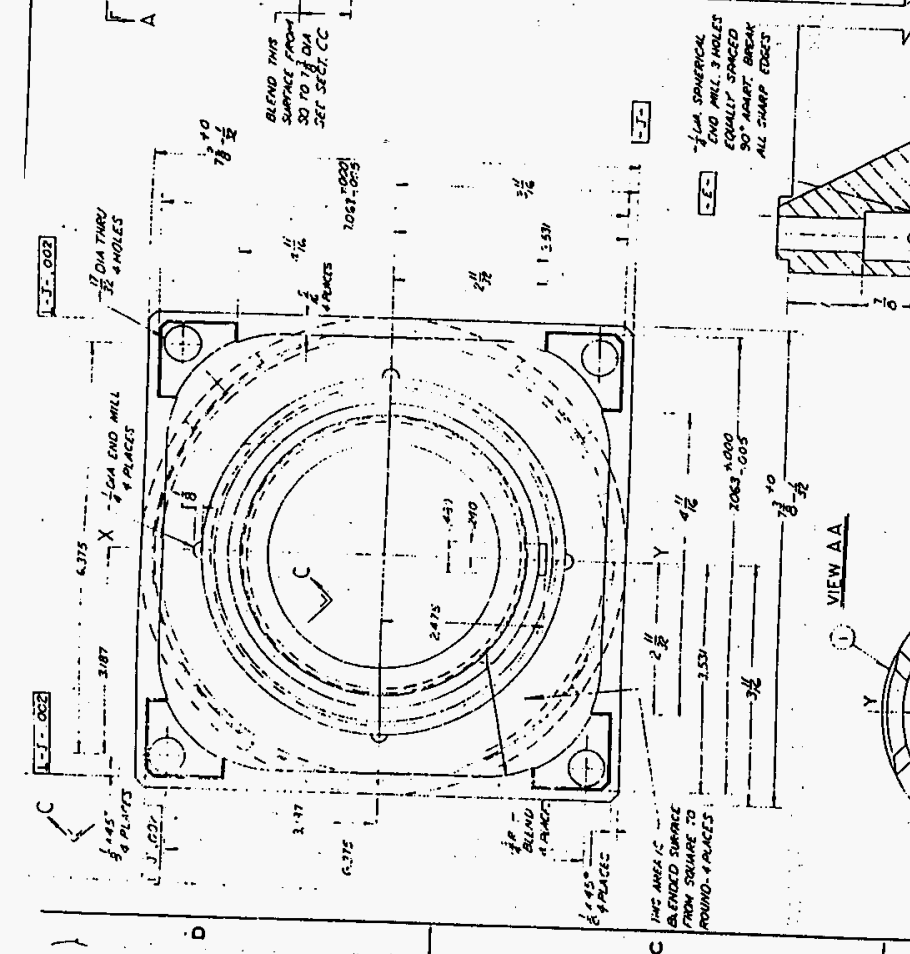

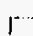
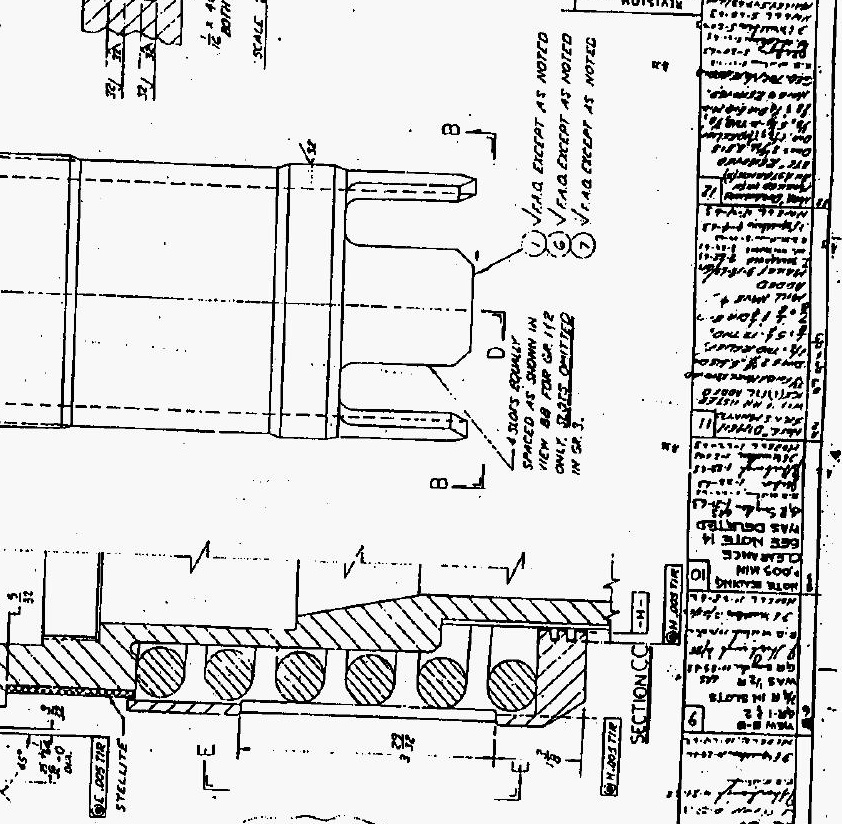

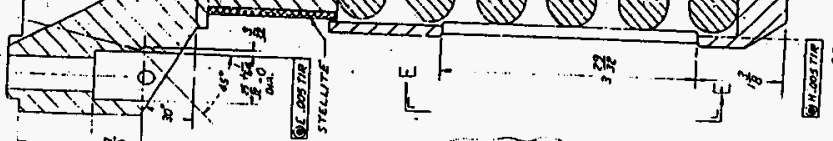

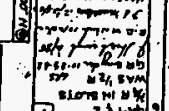

(1)

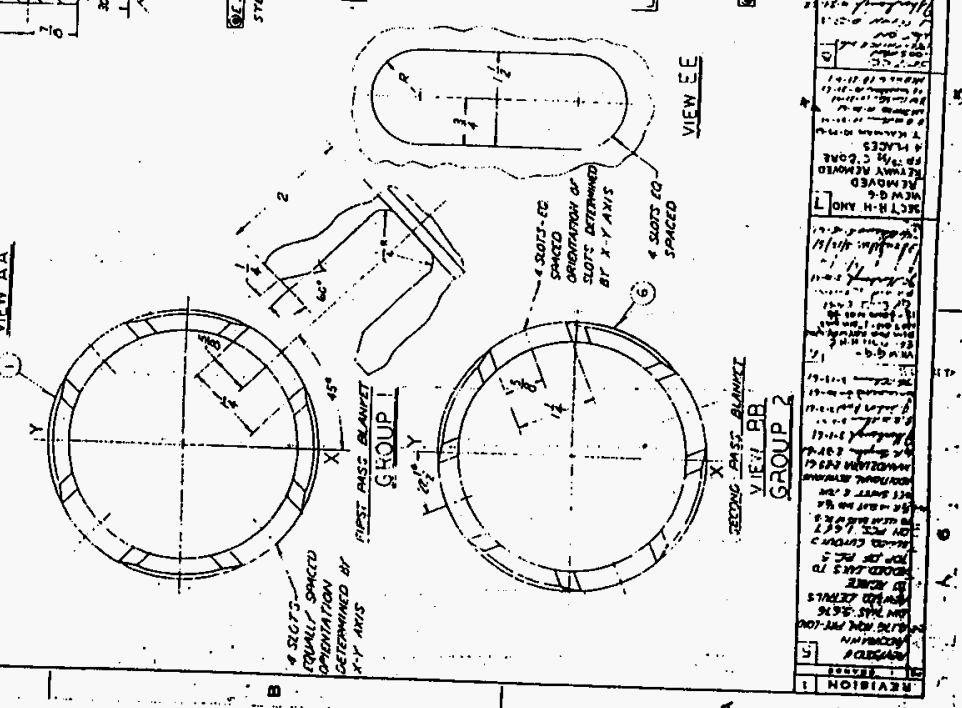


THIS PAGE INTENTIONALLY LEFT BLANK 
THIS PAGE NNTENTIONALLY LEFT BLANK 


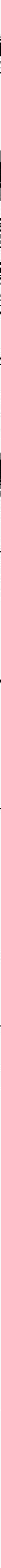


THIS PAGE INTENTIONALLY

LEFT' BLANK 


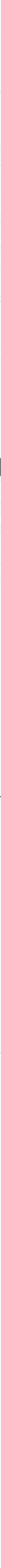


THIS PAGE INTENTIONALLY LEFT BLANK 
THIS PAGE INTENTIONALLY LEFT BLANK 
WHC-SD-WM-ES-394 REV O

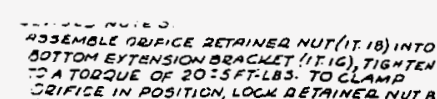

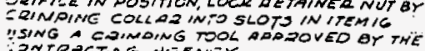

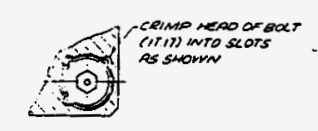

$\frac{\text { SECTION } 39}{\text { gixioces }}$

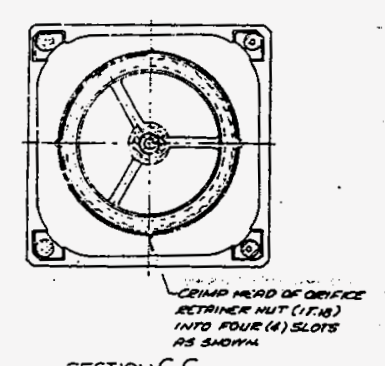

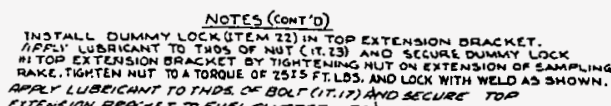

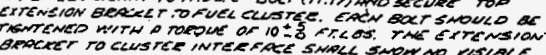

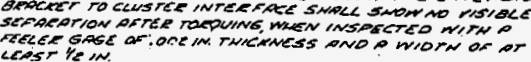

secrionc-c

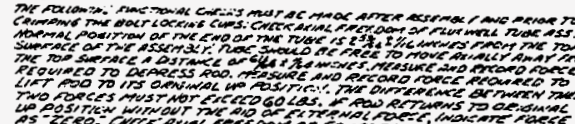

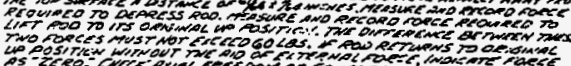

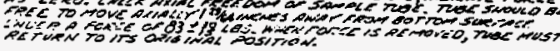
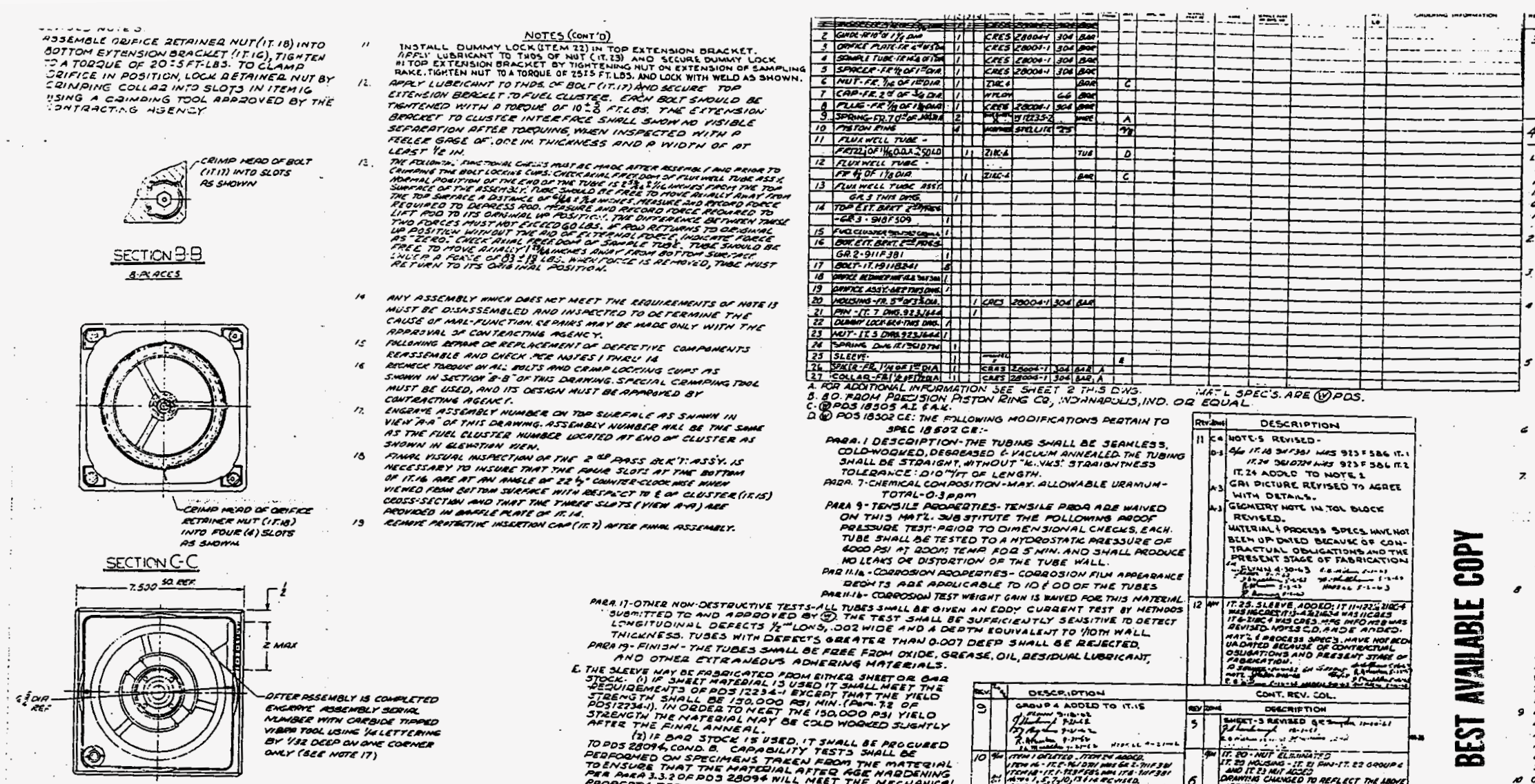

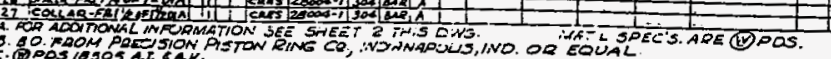

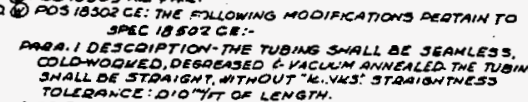

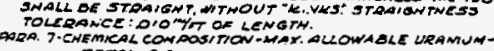

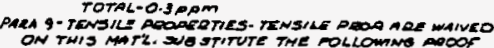

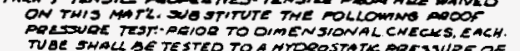

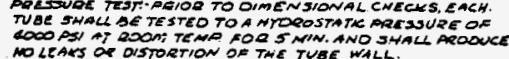

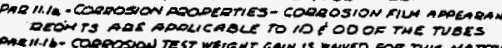

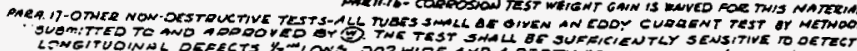

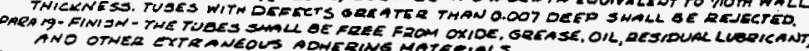

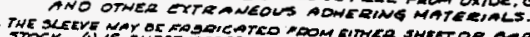

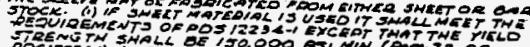

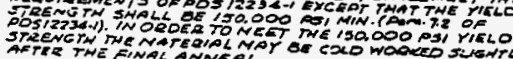

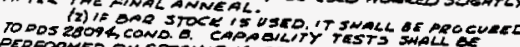

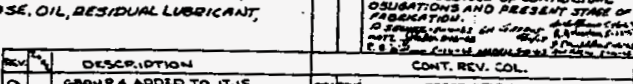

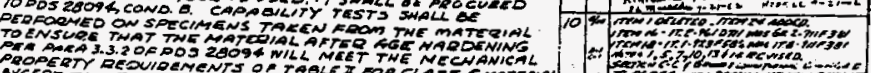

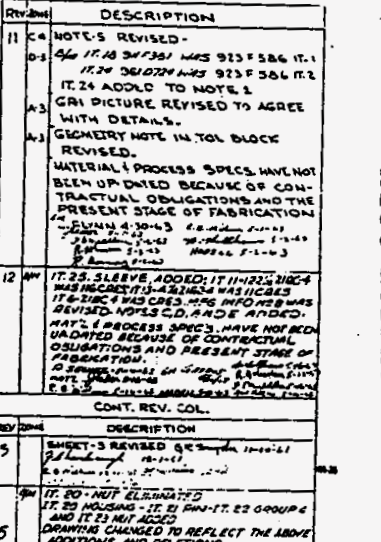
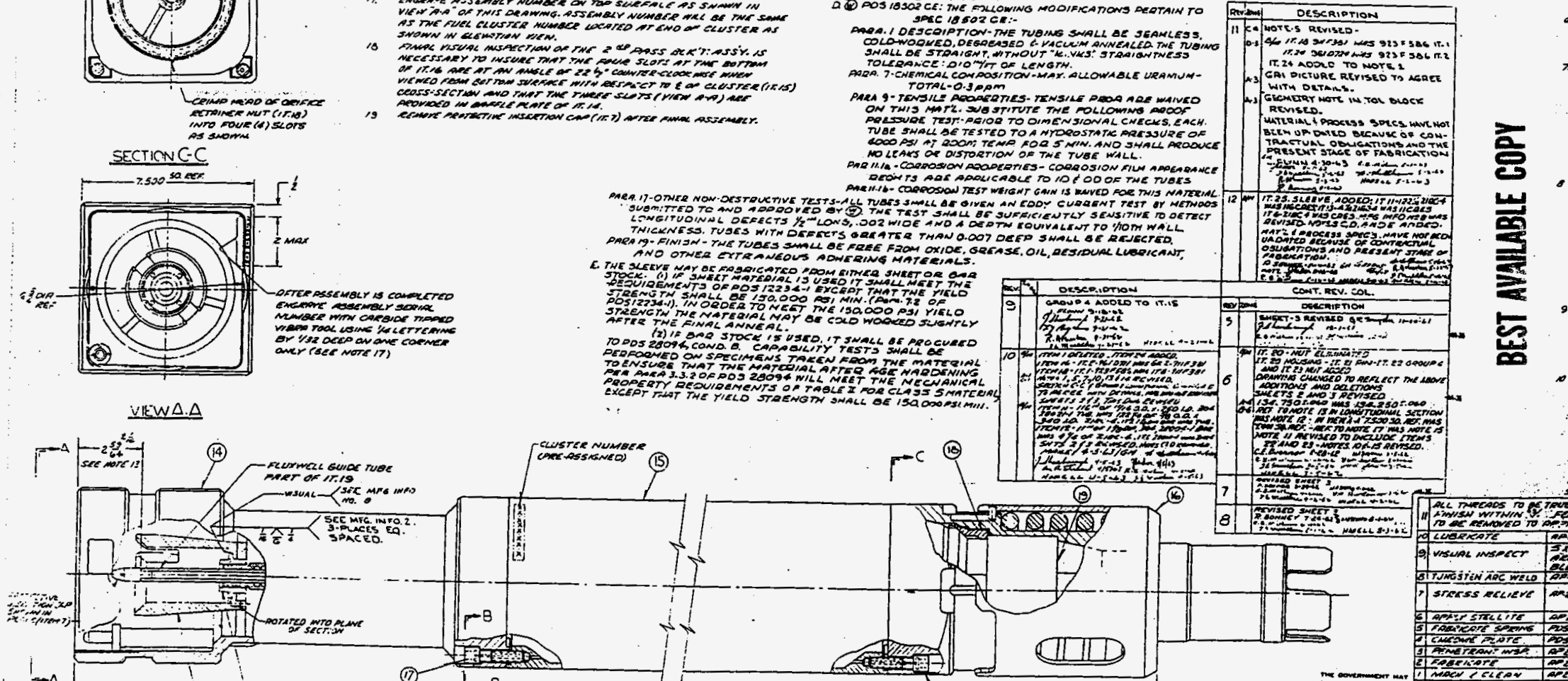

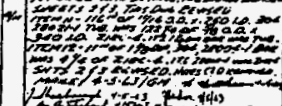

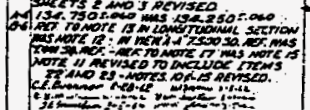
(7) NIIID (8) 7 .

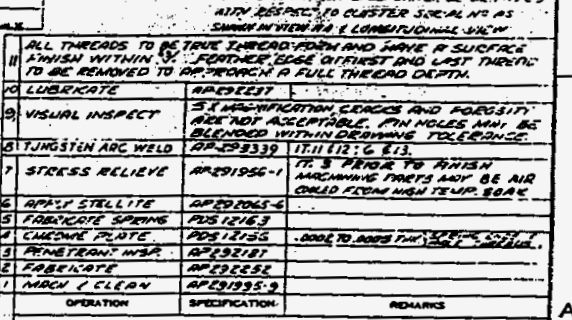

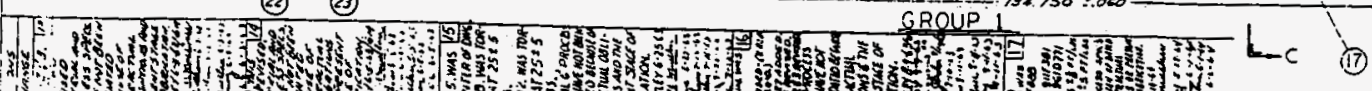

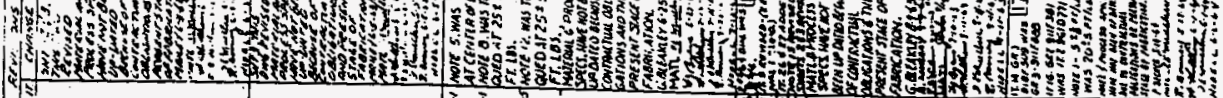


THIS PAGE INTENTIONALLY LEFT BLANK 
THIS PAGE INTENTIONALLY LEFT BLANK 
WHC-SD-WM-ES-394 REV 0
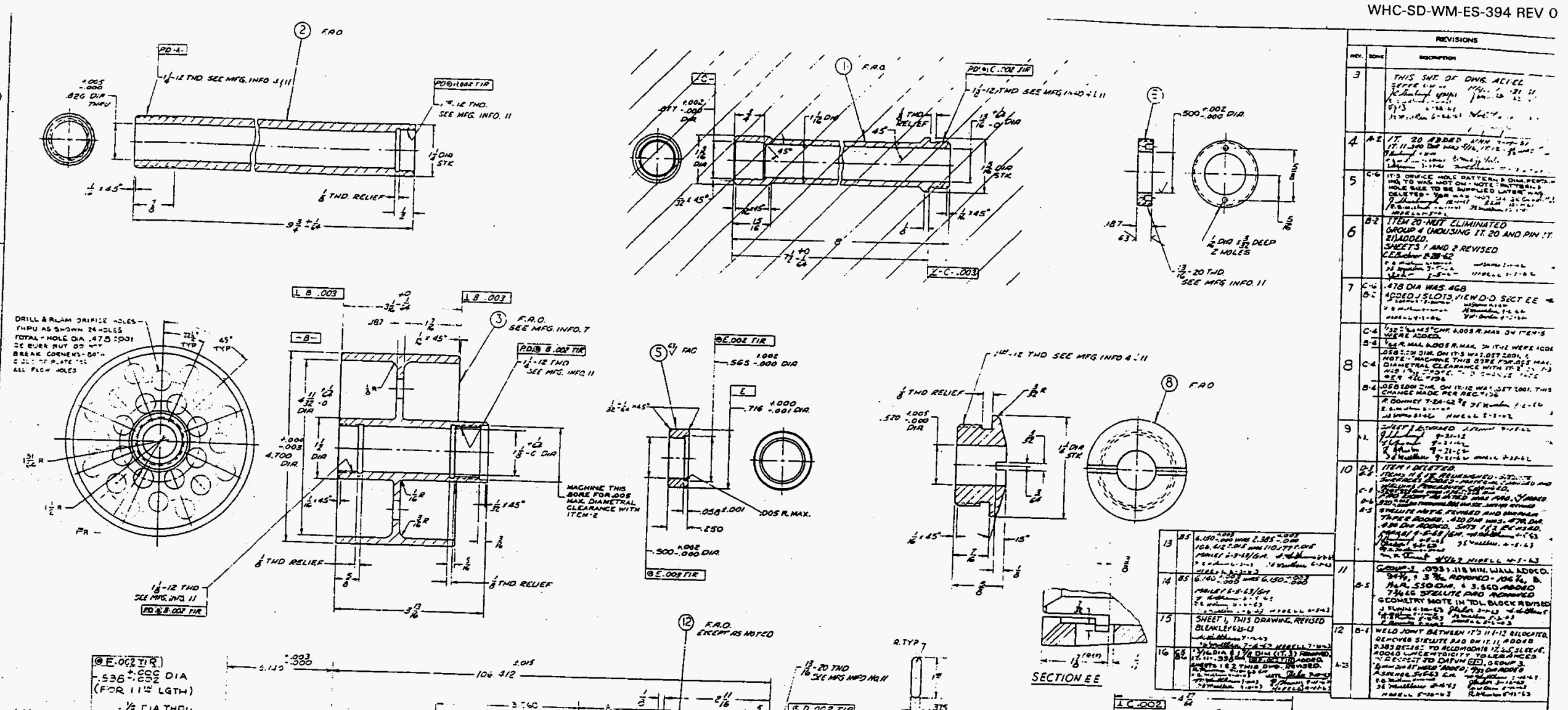

8

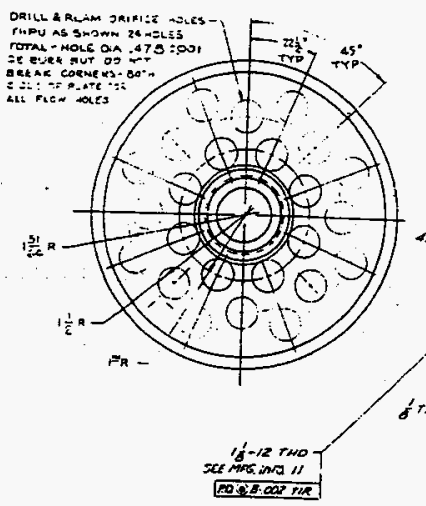

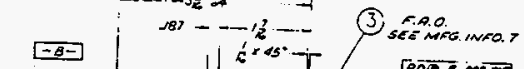

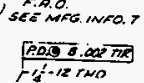

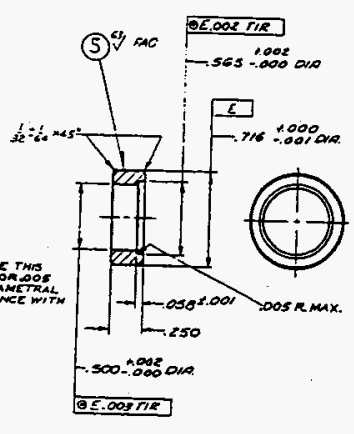

बE. OCTEI

(12) simeos wored

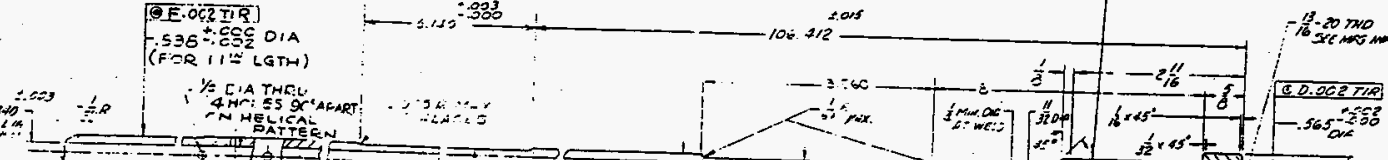

等

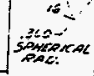

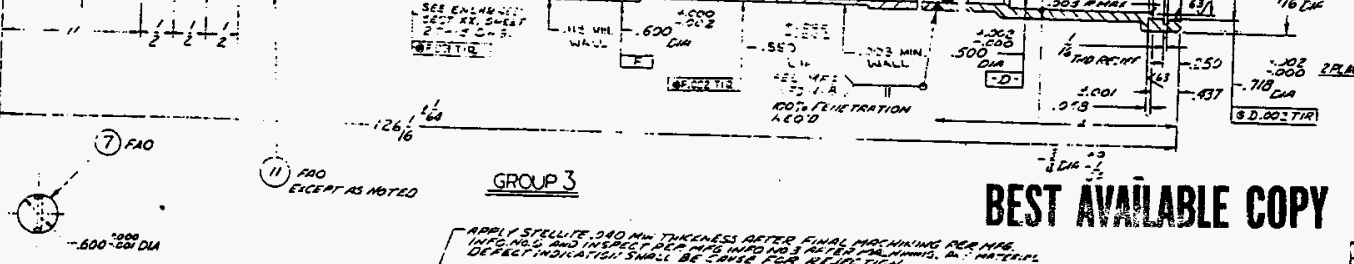
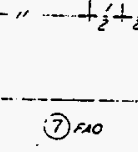

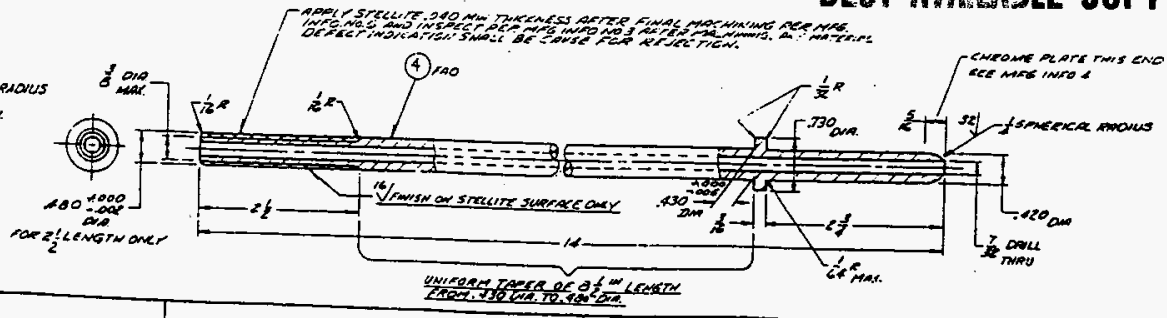

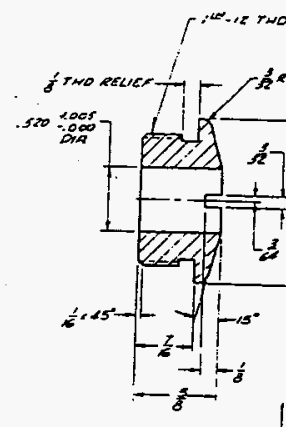

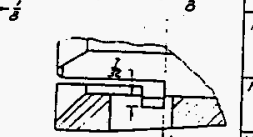

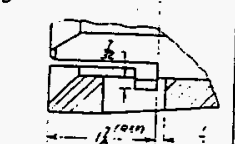
SECTIONEE
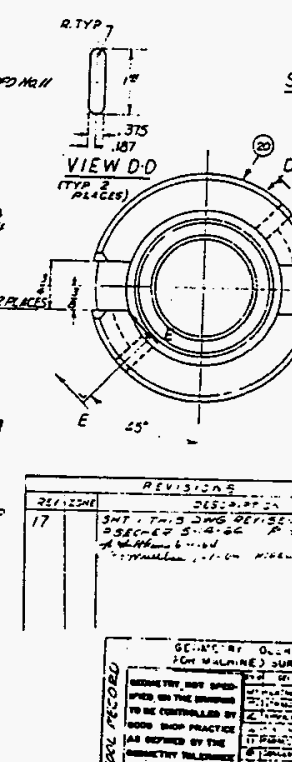

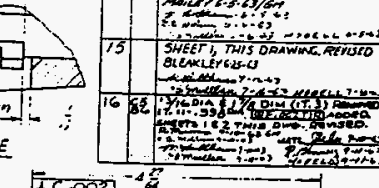

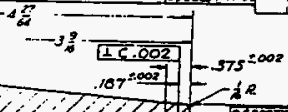

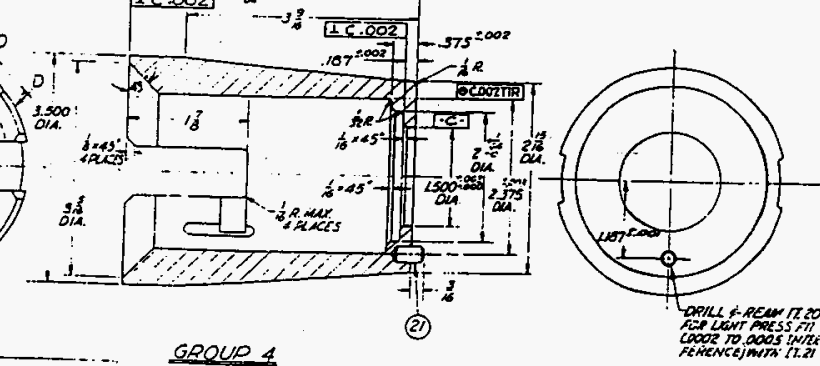

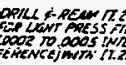

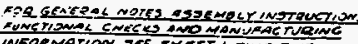

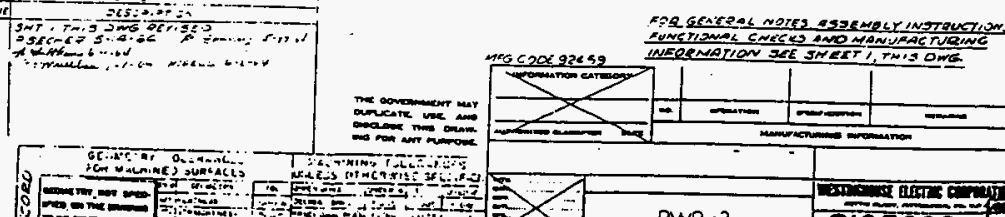


THIS PAGE INTENTIONALLY LEFT BLANK 


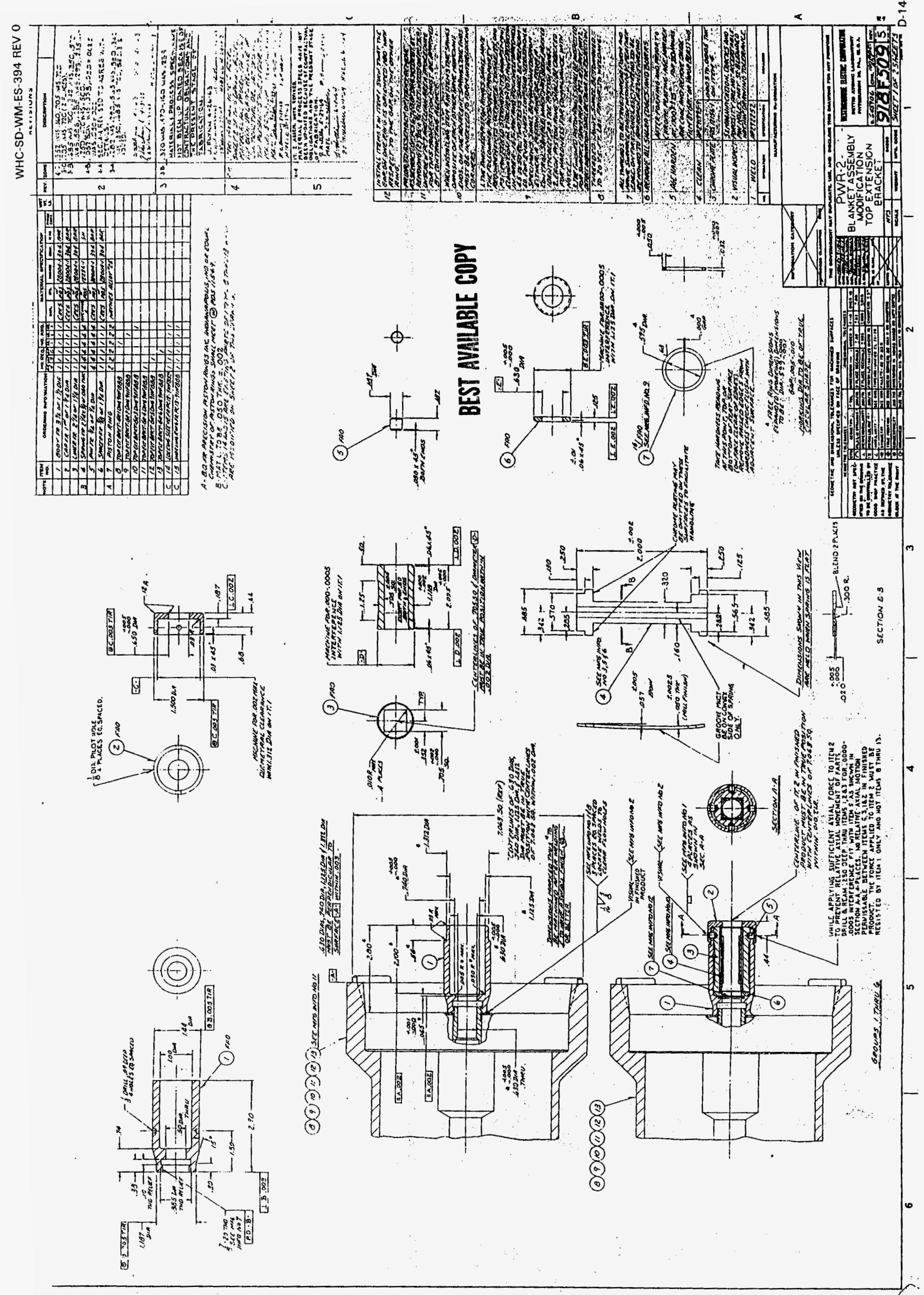


THIS PAGE INTENTIONALLY LEFT BLANK 


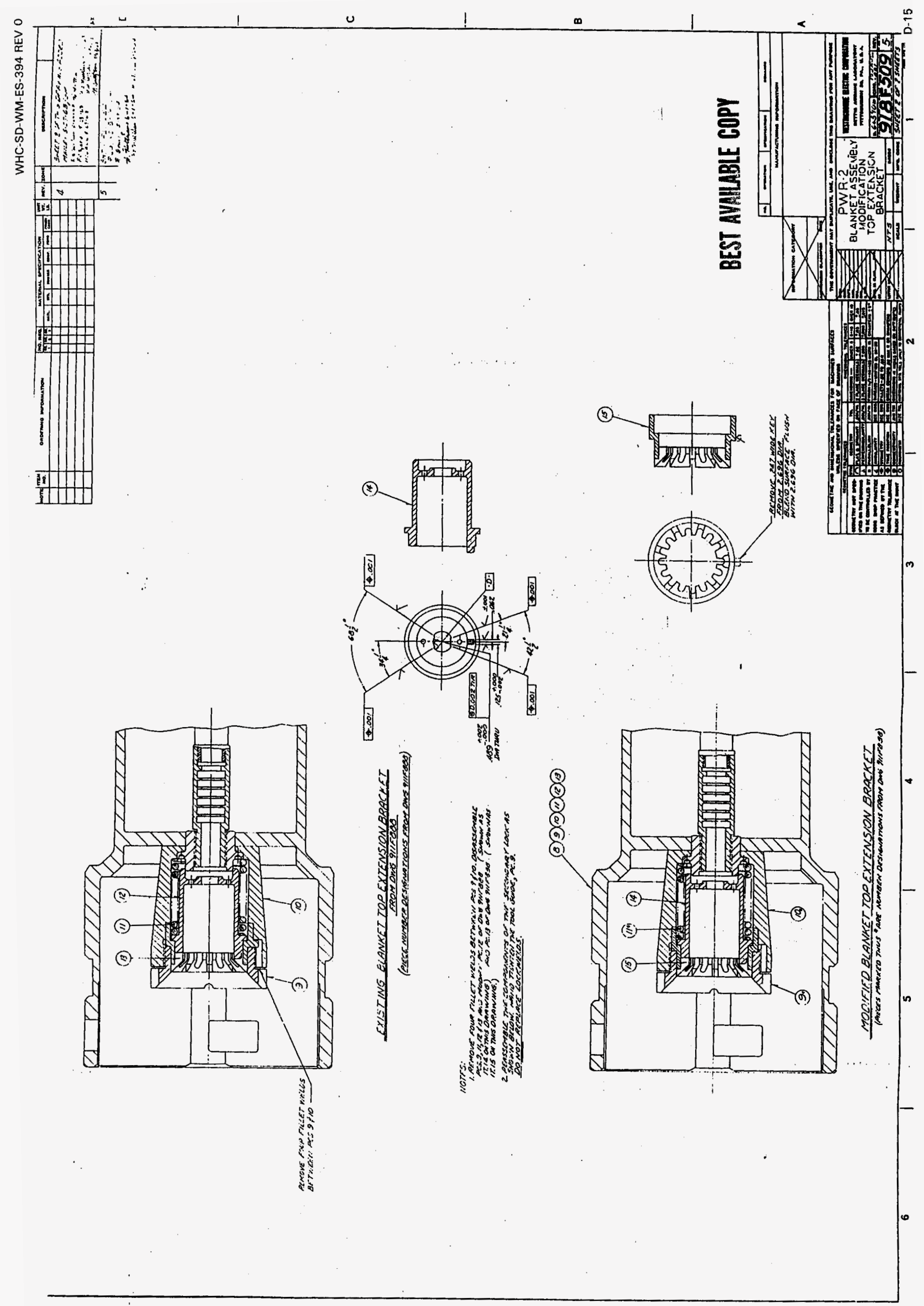


THIS PAGE NNTENTIONALLY LEFT BLANK 
$--7,50030$. REE

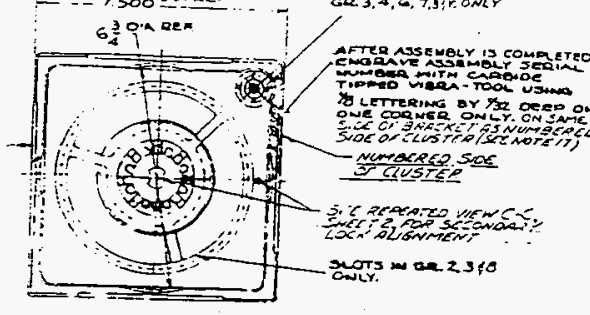

VIENC-C

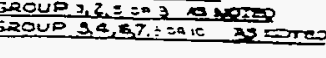
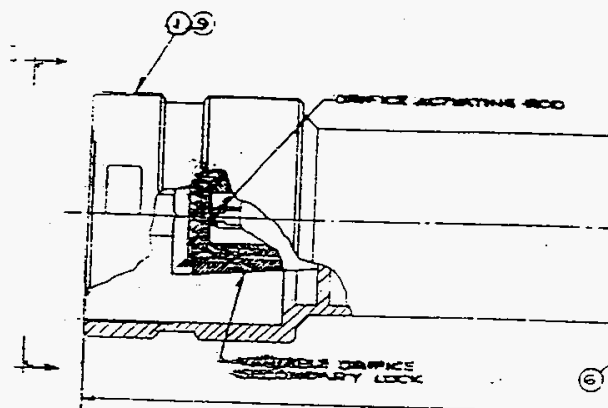

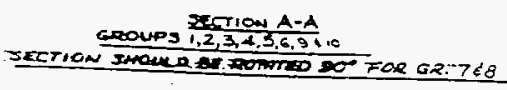

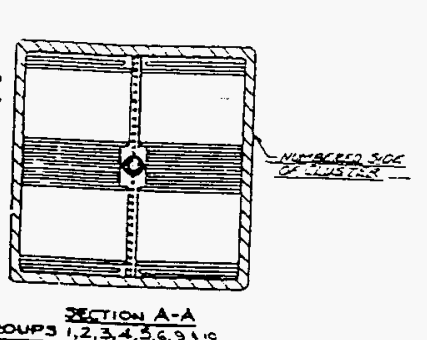

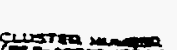

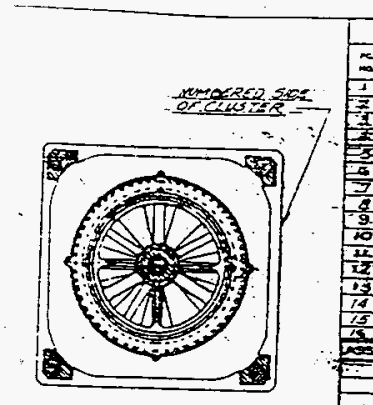

gexperses.

WHC-SD-WM-ES-394 REV 0

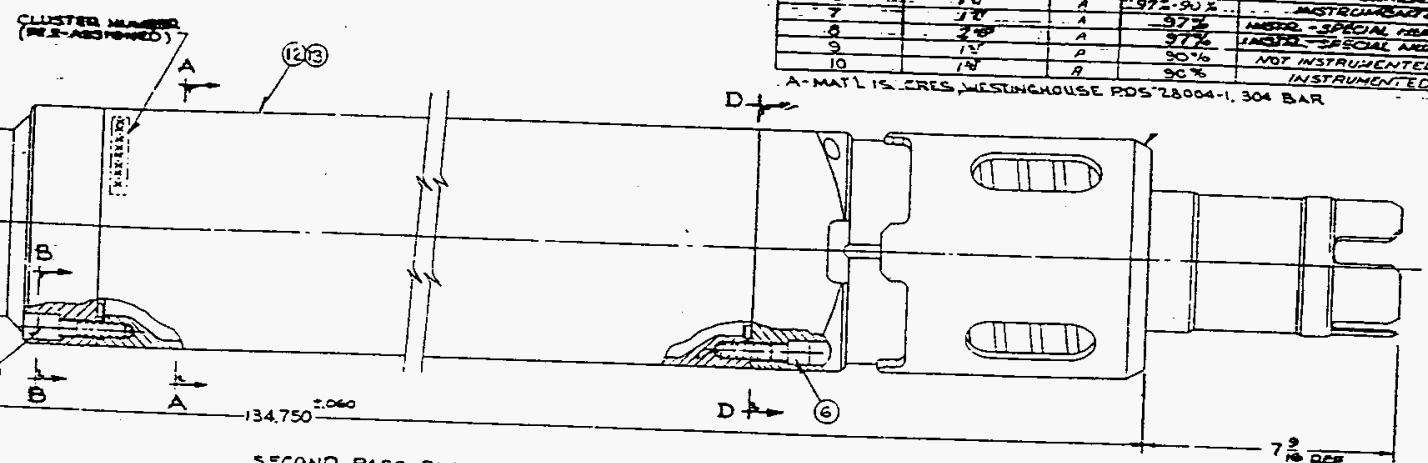

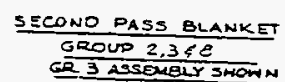
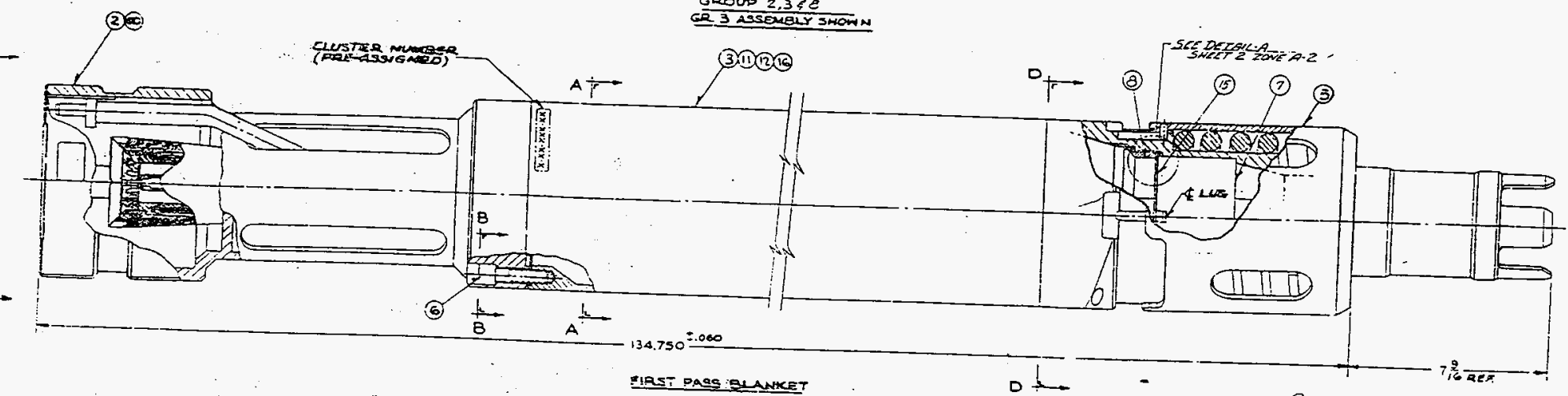

P1QST PAgS OUANKET

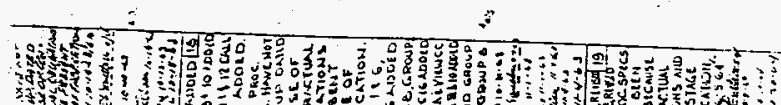

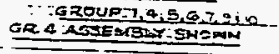

(6)

3.3.

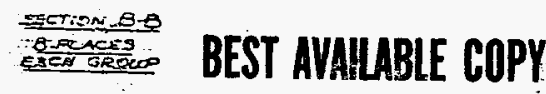

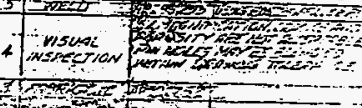

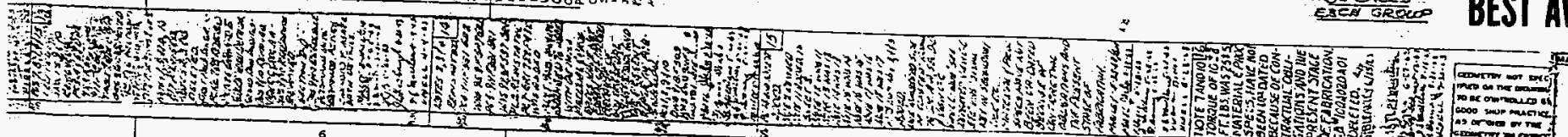

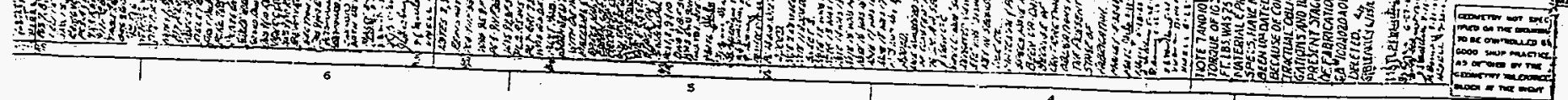

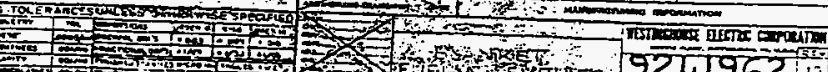

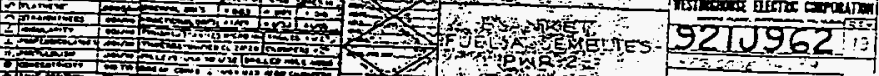


THIS PAGE INTENTIONALLY LEFT BLANK 
WHC-SD-WM-ES-394 REV O

1

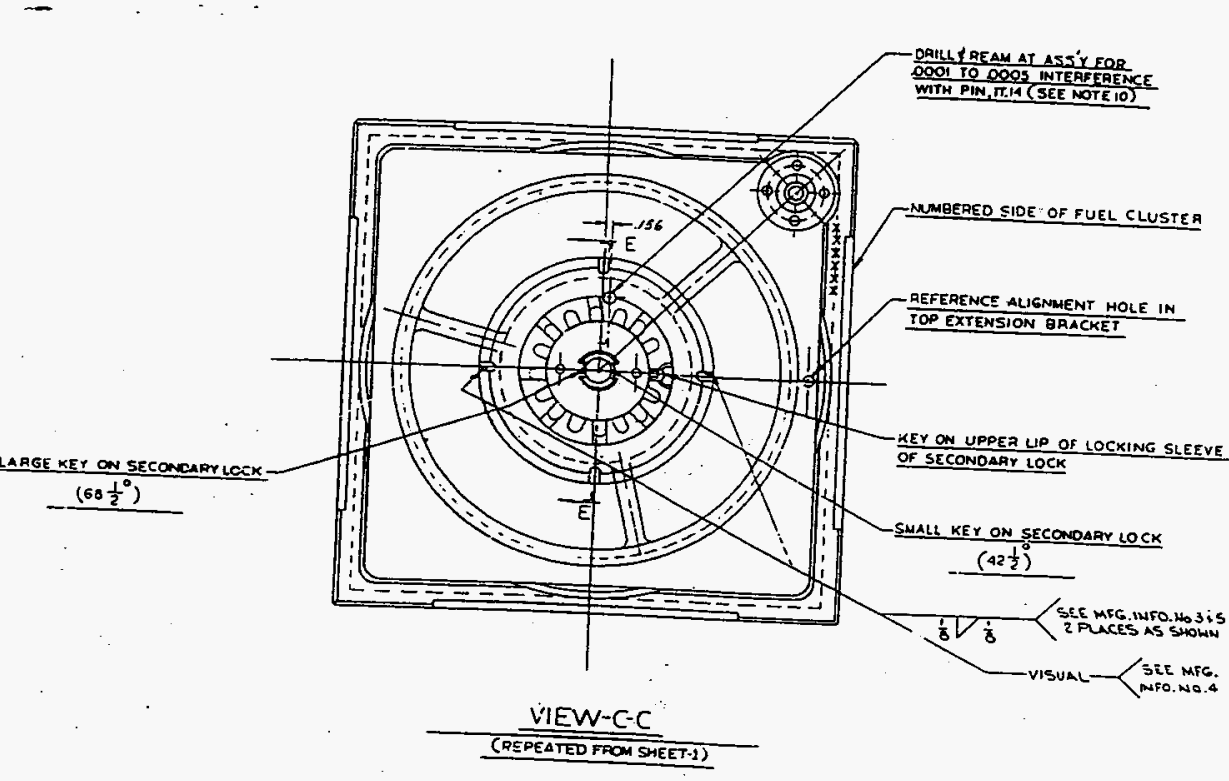

DAMPING RING INSTALLATION PROCEOURE
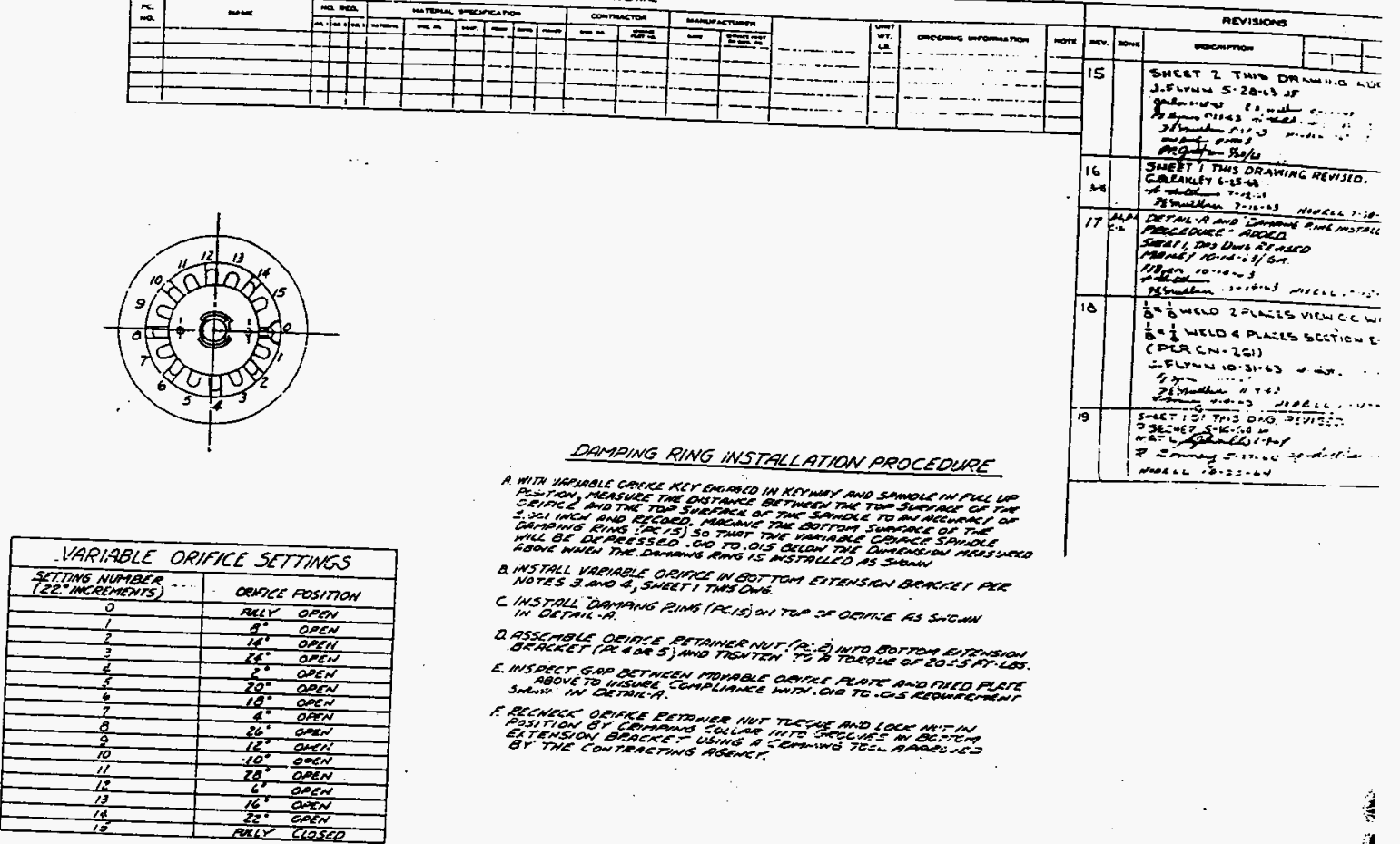

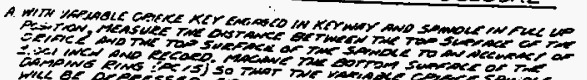

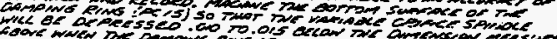

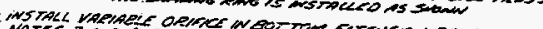

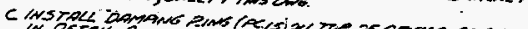

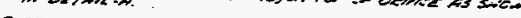

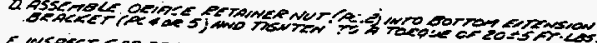

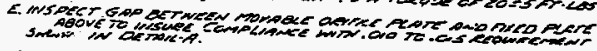

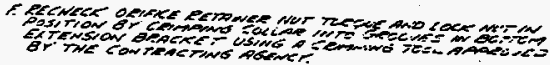

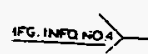

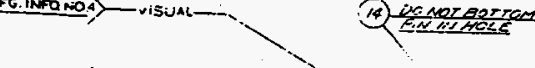

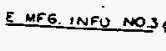

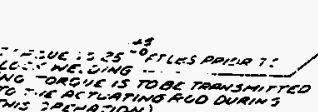

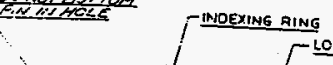

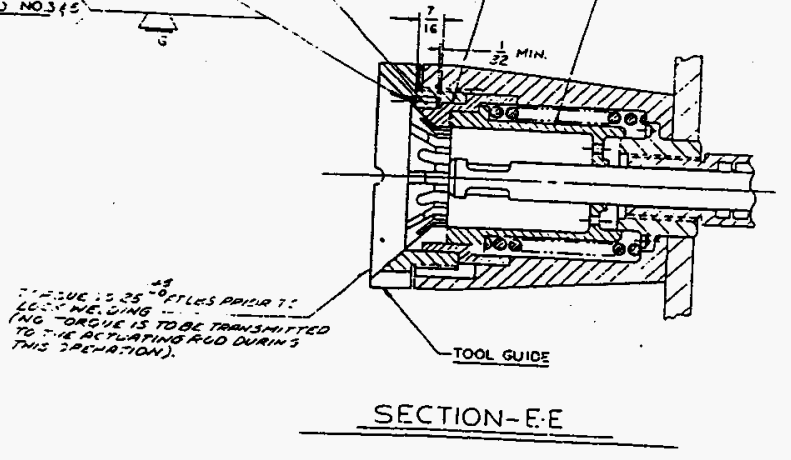

SECONDARY LOCK ALGGNMENI

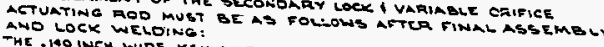
MUST Buex wibe xer on the u

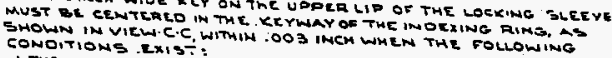

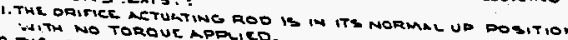

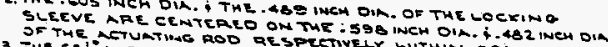

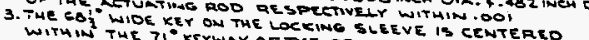

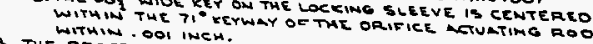

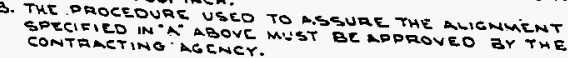

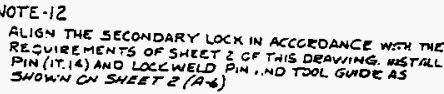

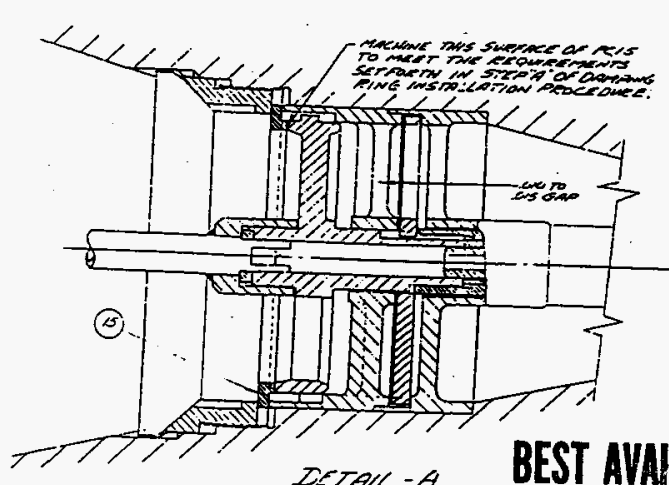

DETAL-A

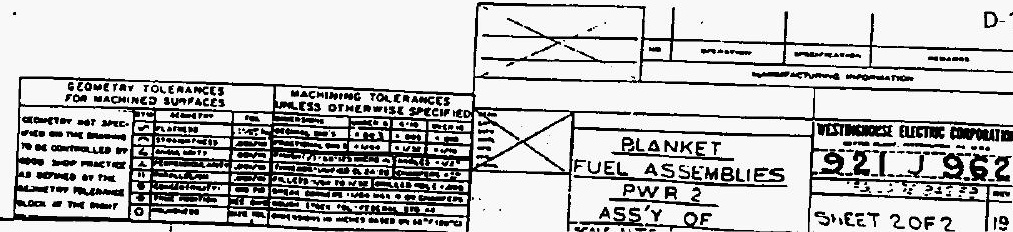


THIS PAGE INTENTIONALLY LEFT BLANK 


\section{THIS PAGE INTENTIONALLY}

LEFT BLANK 
THIS PAGE INTENTIONALLY LEFT BLANK 


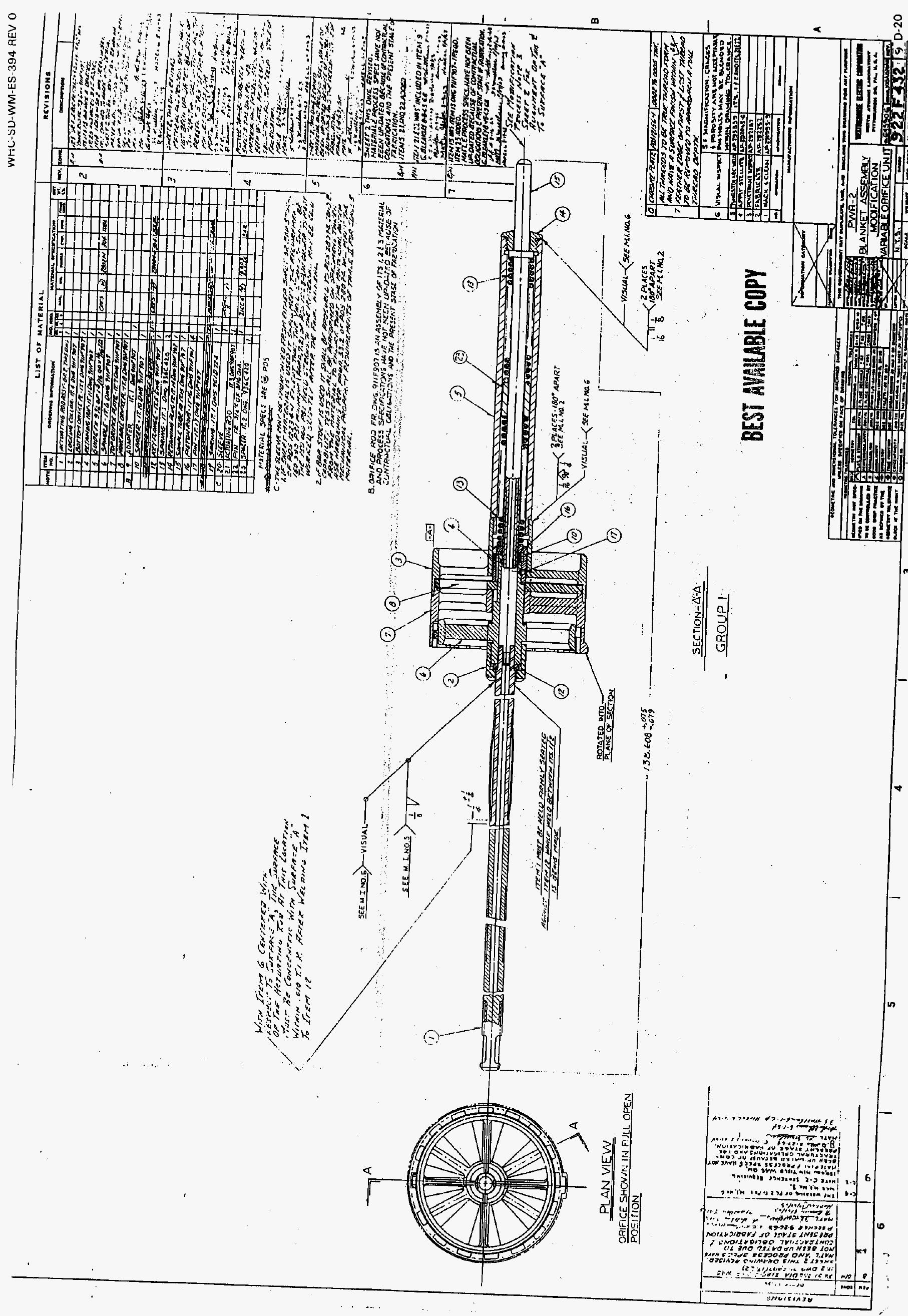


THIS PAGE INTENTIONALLY LEFT BLANK 


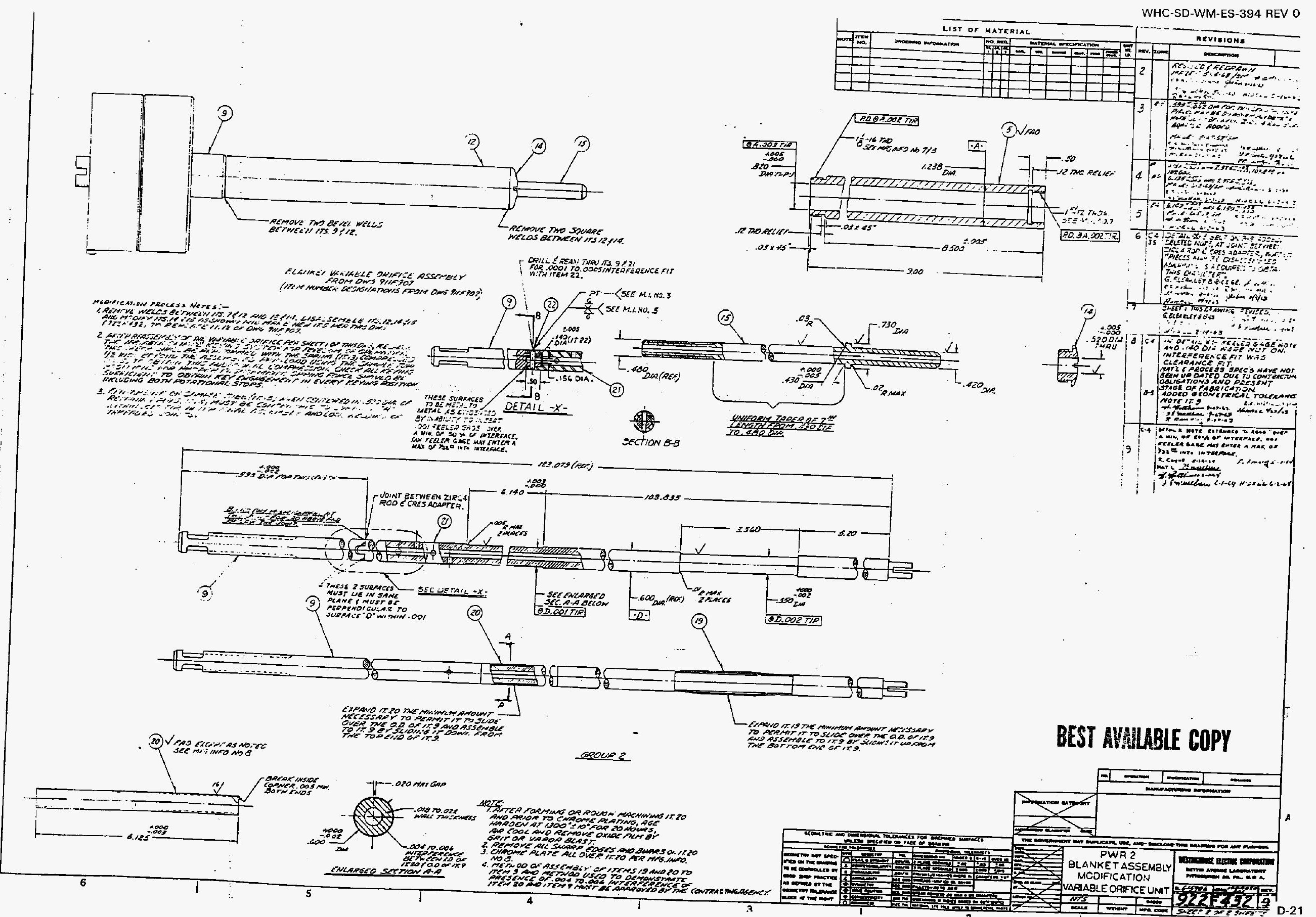


THIS PAGE INTENTIONALLY

LEFT BLANK 


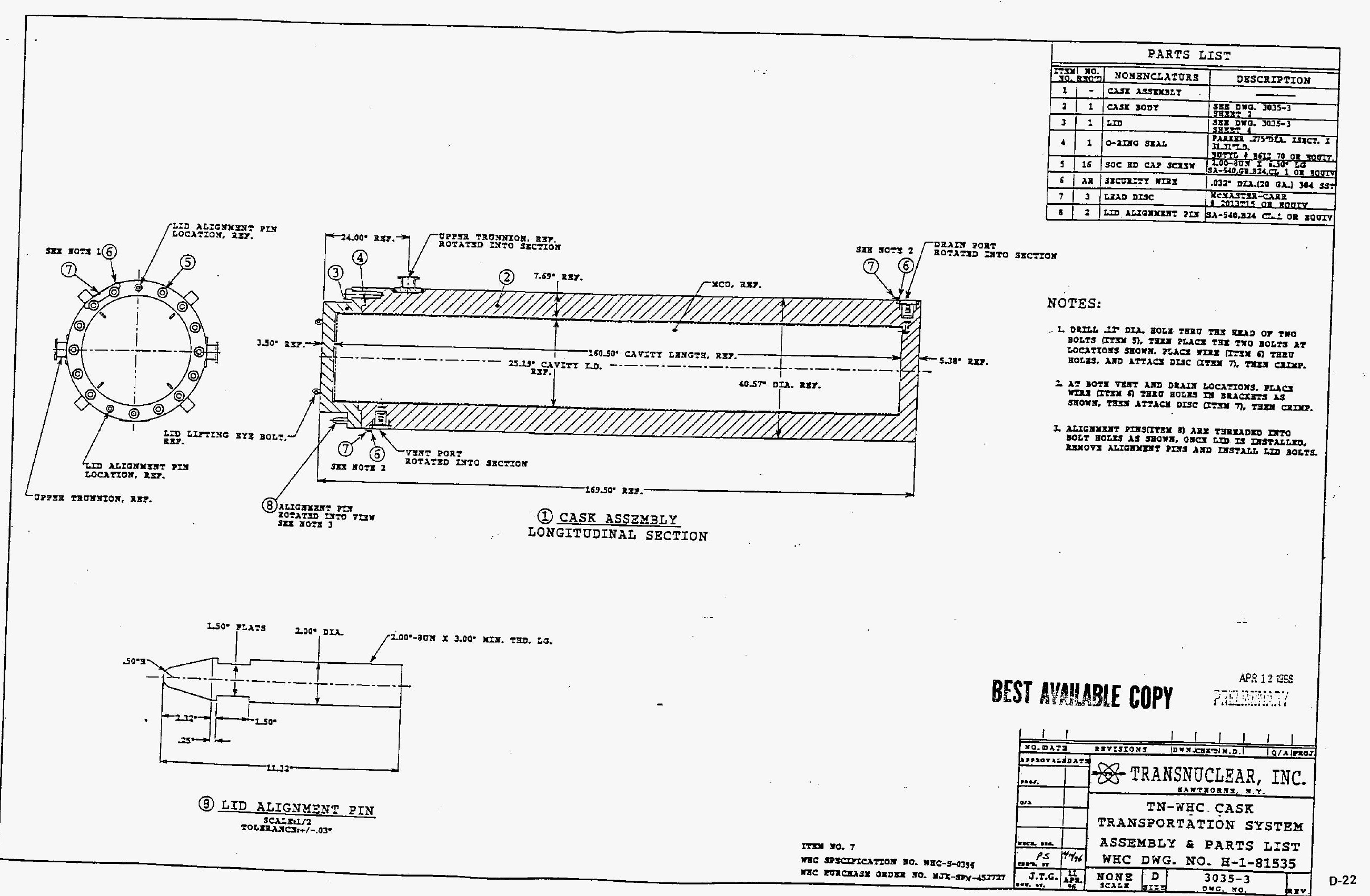


THIS PAGE INTENTIONALLY LEFT BLANK 





THIS PAGE INTENTIONALLY

\section{LEFT BLANK}




\section{PARTS LIST}

\begin{tabular}{|c|c|c|c|c|}
\hline \multirow{2}{*}{\multicolumn{3}{|c|}{ 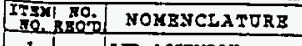 }} & \multirow{2}{*}{ DESCRIPTION } & \multirow{2}{*}{ MATBRIA } \\
\hline & & & & \\
\hline 2 & 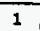 & LID & & \\
\hline 3 & 6 & IYI BOLY & 1.56 & \\
\hline
\end{tabular}

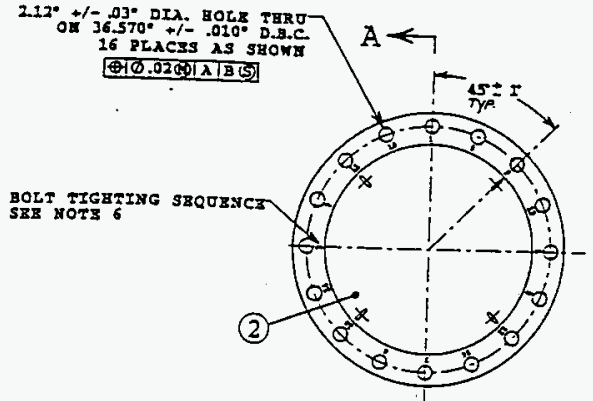

$A \leftarrow$

IOP VIEW

(1) LID ASSEMBLY

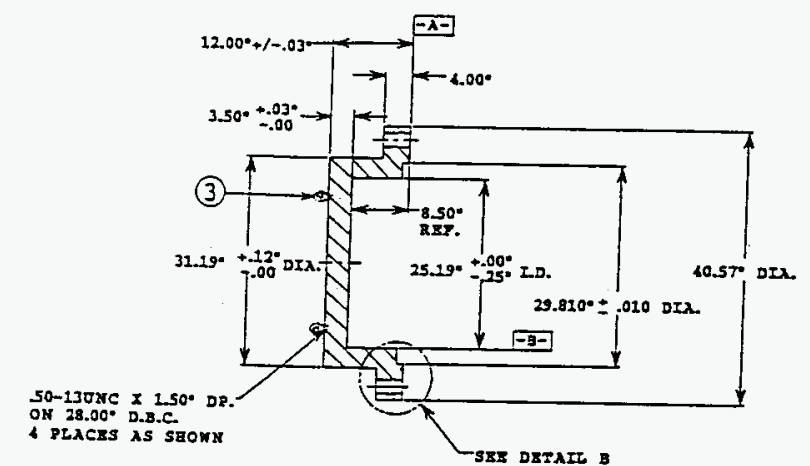

SECTION A-A

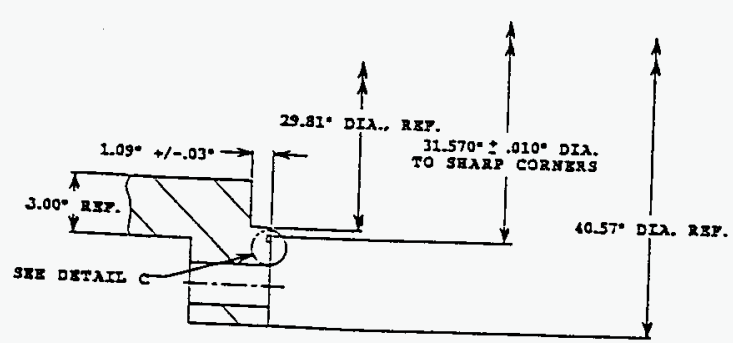

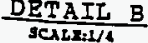

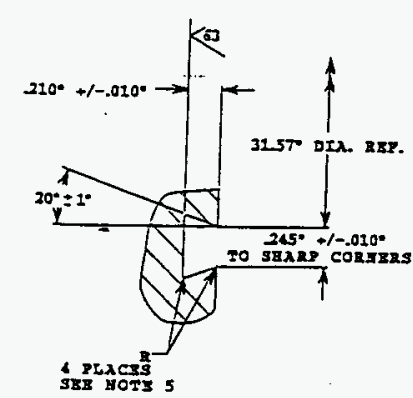

$\frac{\text { DETAIL } C}{\text { SCALE:1/2 }}$

\section{NOTES:}

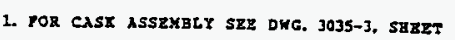

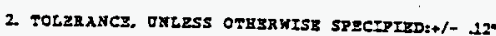

1. REYOVE ALL BORRS E MBLD SPLATTER AND BREAX ALL SHARI ZDGZS.

4. SJRPACZ PINISB, UNLESS OTHERWISE SPECTrizD: 125/

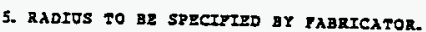

6. TEXT SIzB 50* aTGB, EMGRaved IATO LID.

7. PAsRicitor EAS OPTION TO OSB SA-240, TYPE 304

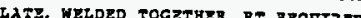

\section{BEST AVALABLE COPY}
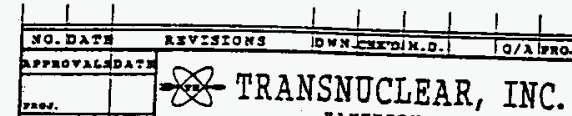

\section{TN-WHC CASR} TRANSPORTATION SYSTEM

ITEM xo. 7 IID

$\frac{P S}{20 / 46}$ WHC DWG. NO. H-1-81535 
THIS PAGE INTENTIONALLY

LEFT BLANK 


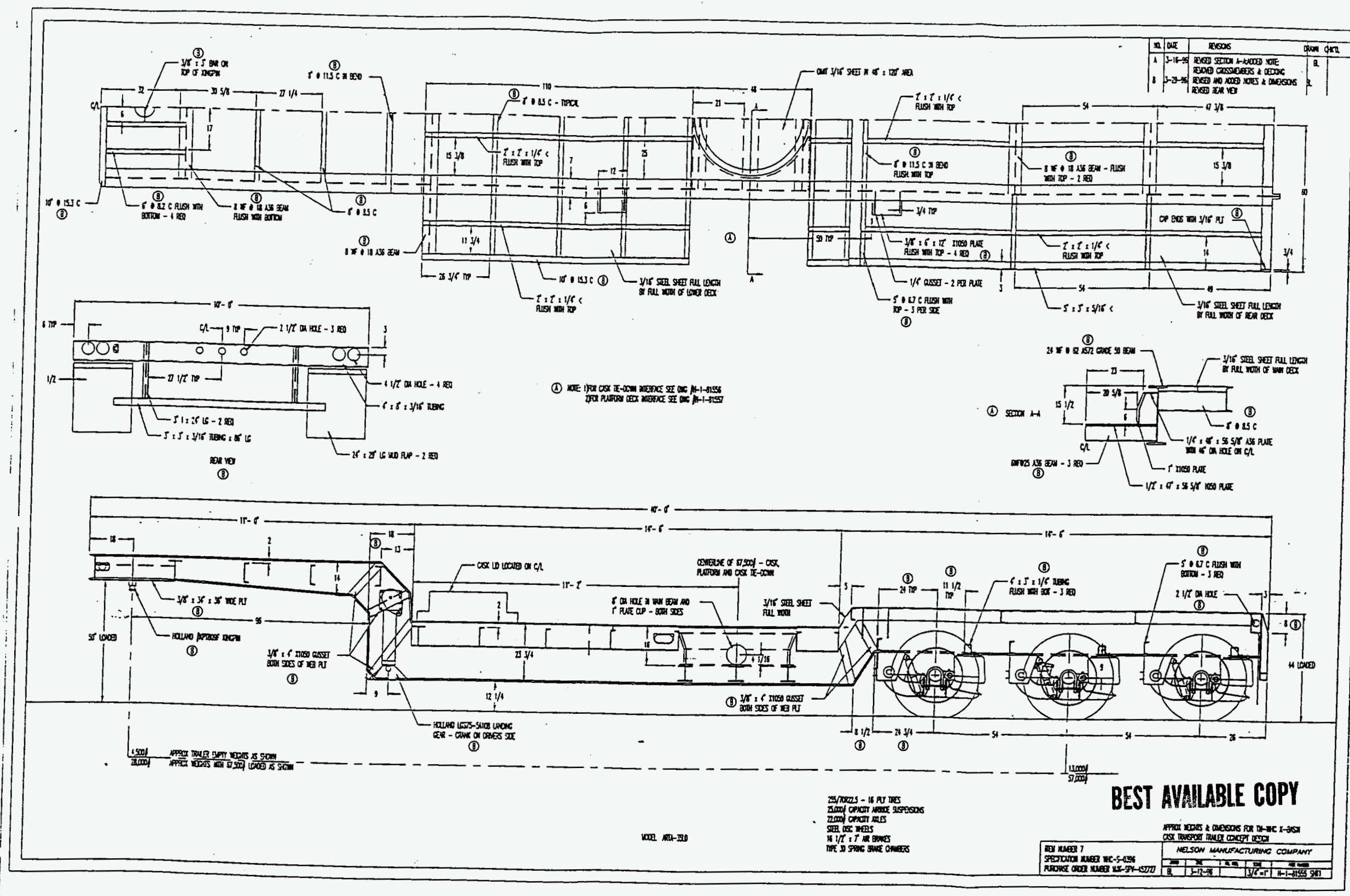


THIS PAGE INTENTIONALLY LEFT BLANK 


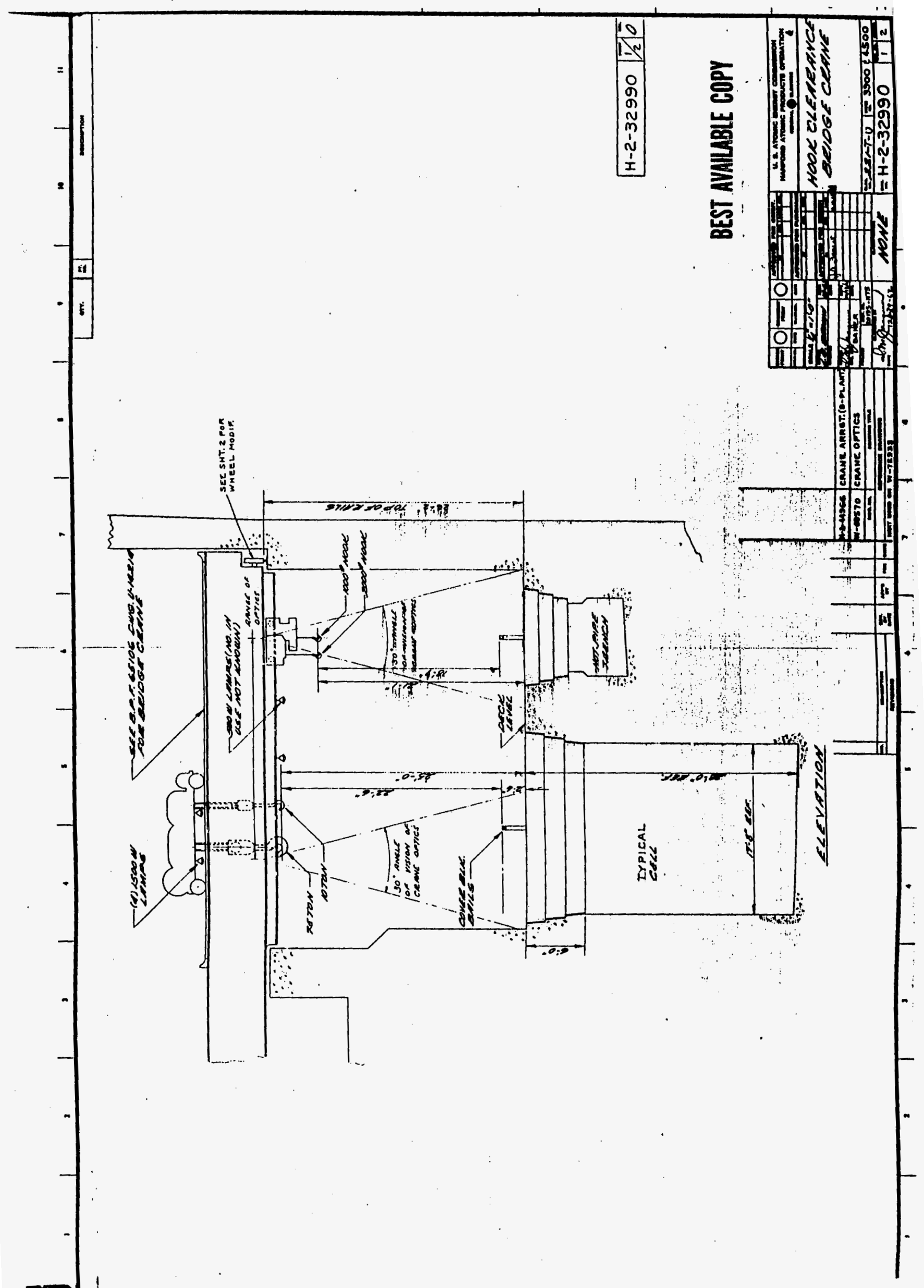


THIS PAGE INTENTIONALLY LEFT BLANK 


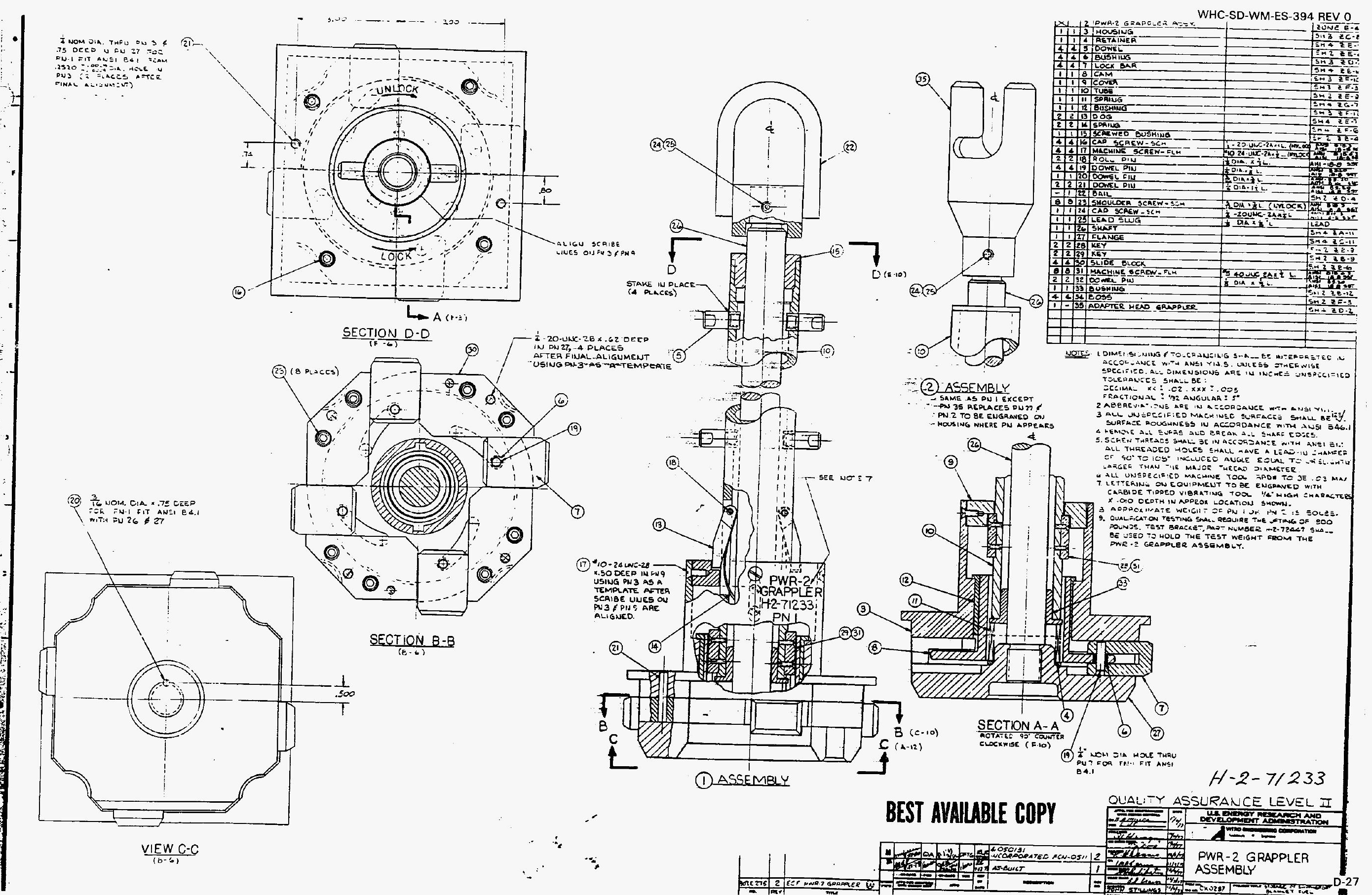


THIS PAGE INTENTIONALLY

LEFT BLANK 


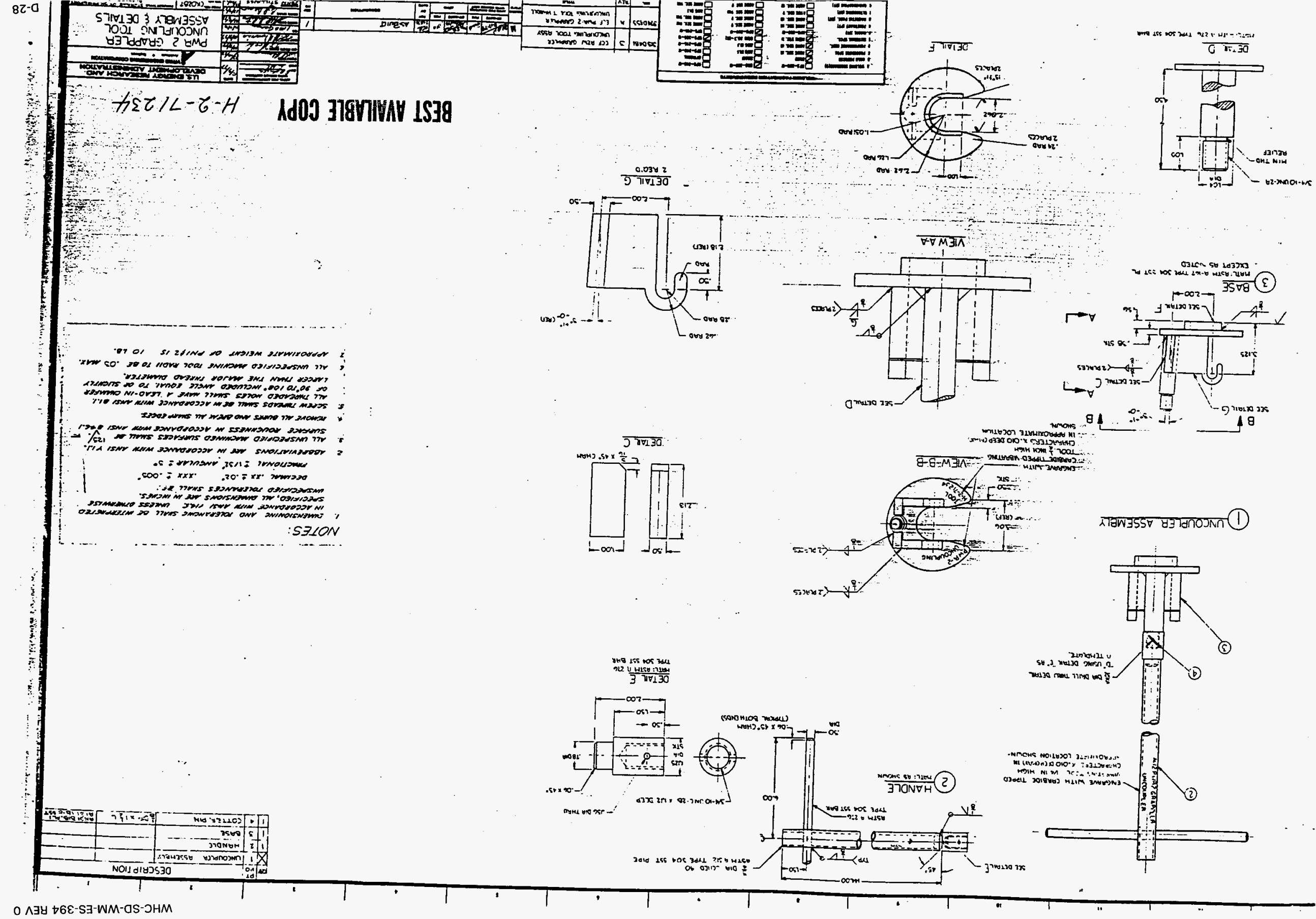


THIS PAGE INTENTIONALLY LEFT BLANK 


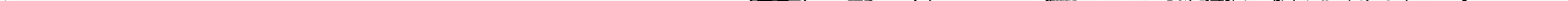


THIS PAGE INTENTIONALLY LEFT BLANK 


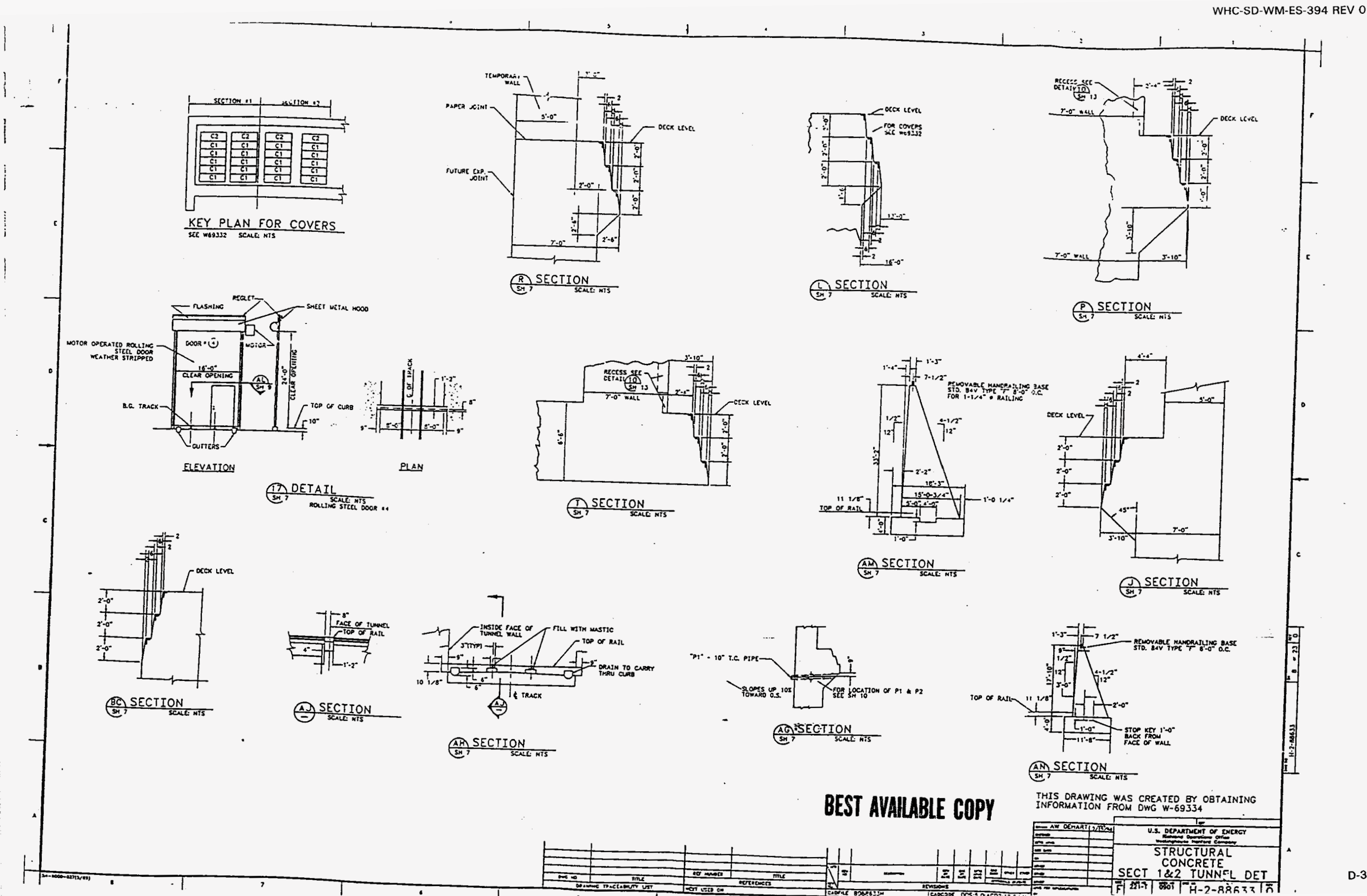

BEST AVALABLE COPY

IHIS DRAWING WAS CREATEO BY OBTAINING
INFORMATION FROM OWG W-69334

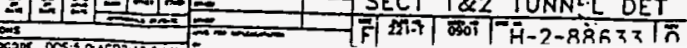


THIS PAGE INTENTIONALLY LEFT BLANK 


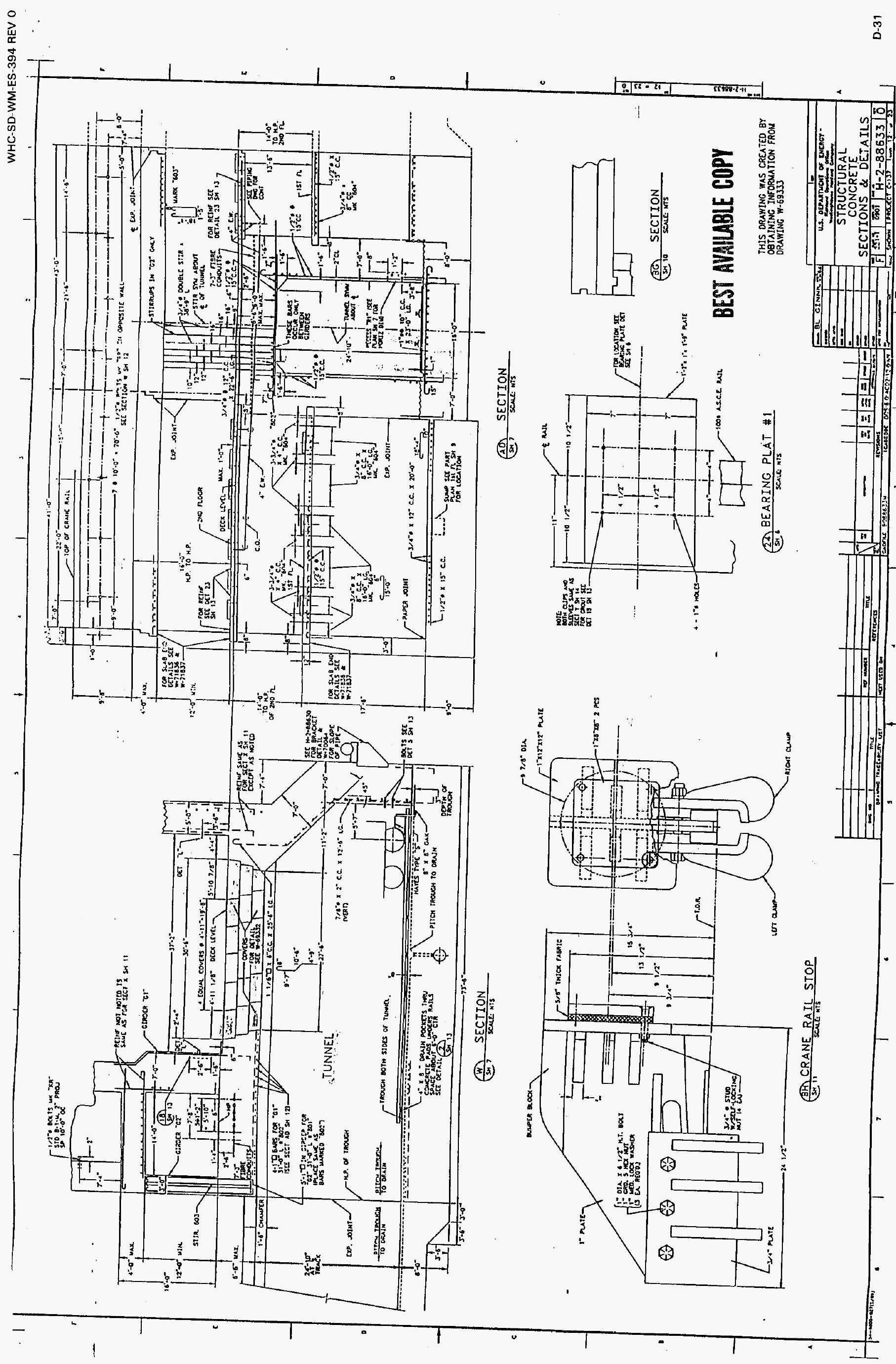


THIS PAGE INTENTIONALLY LEFT BLANK 


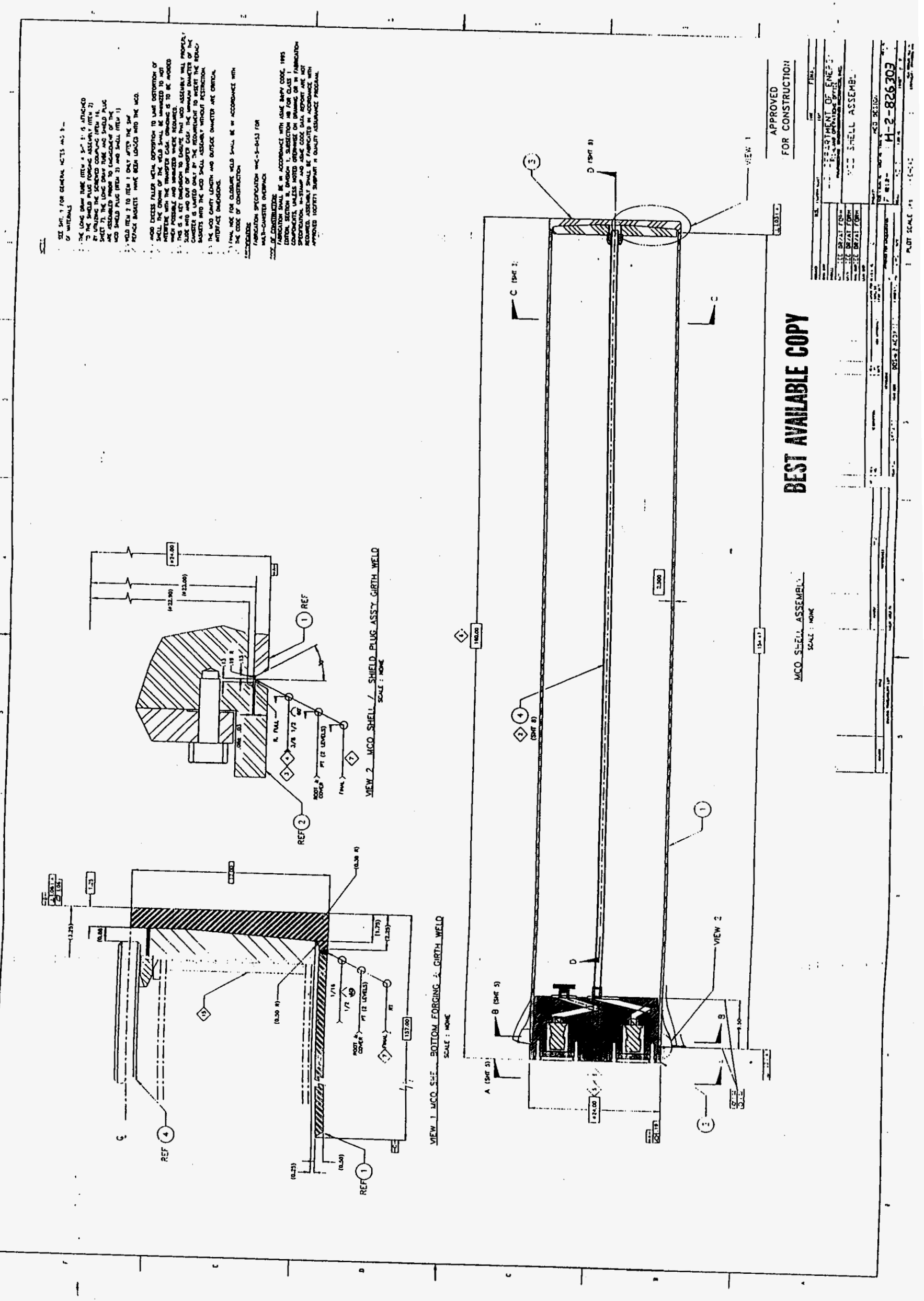


THIS PAGE INTENTIONALLY LEFT BLANK 


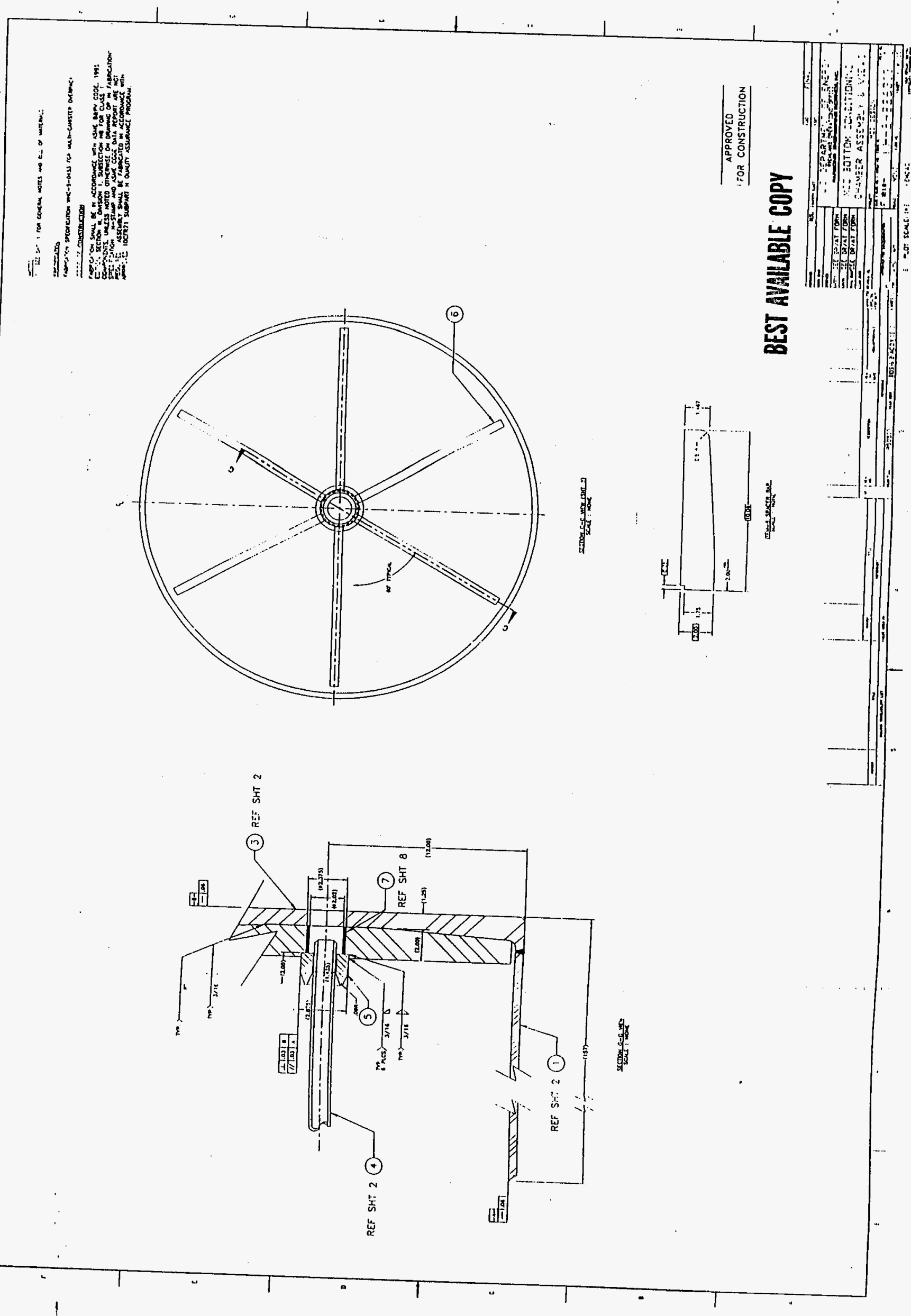


THIS PAGE INTENTIONALLY LEFT BLANK 
THIS PAGE INTENTIONALLY LEFT BLANK 


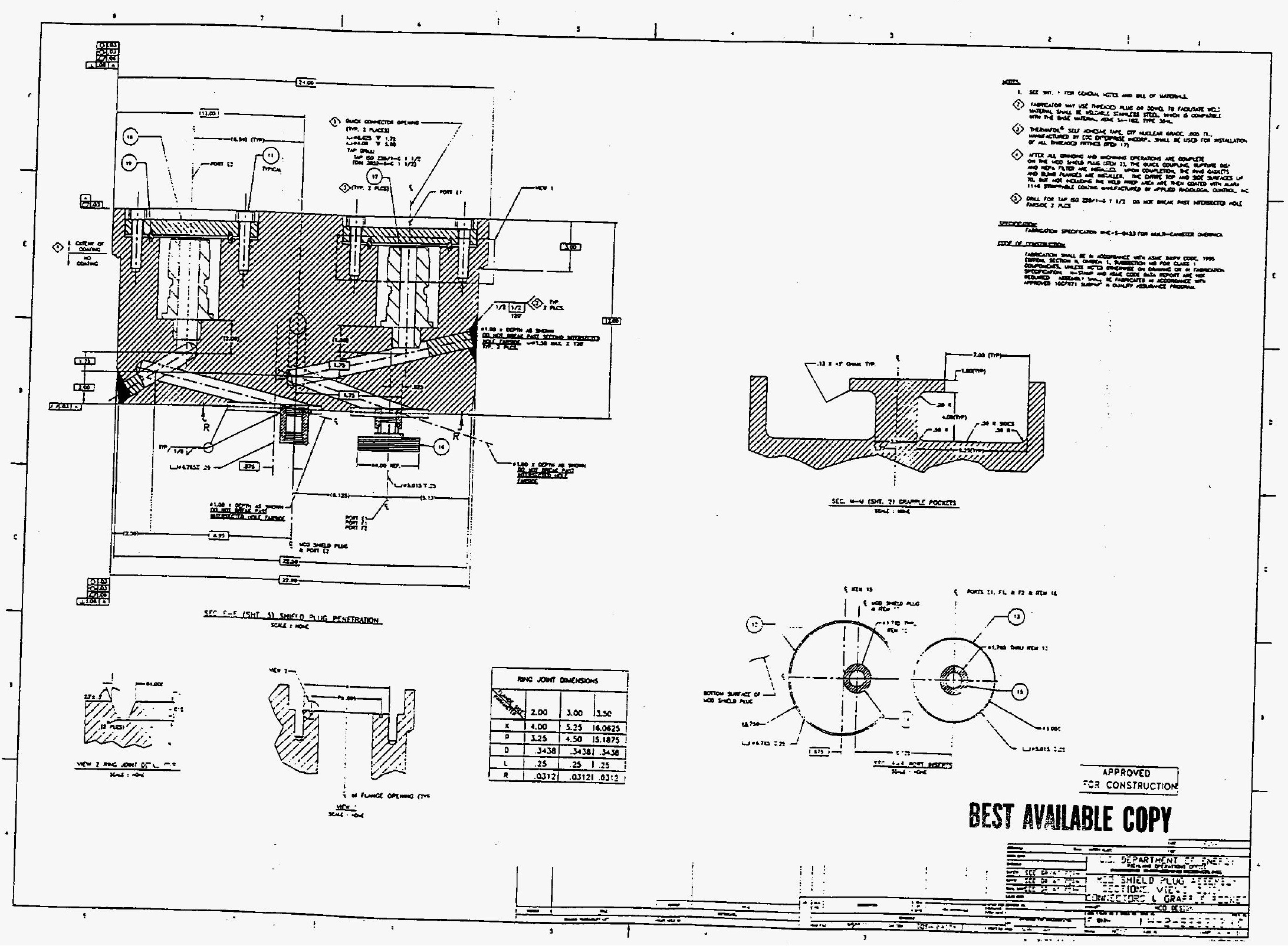


THIS PAGE INTENTIONALLY LEFT BLANK 

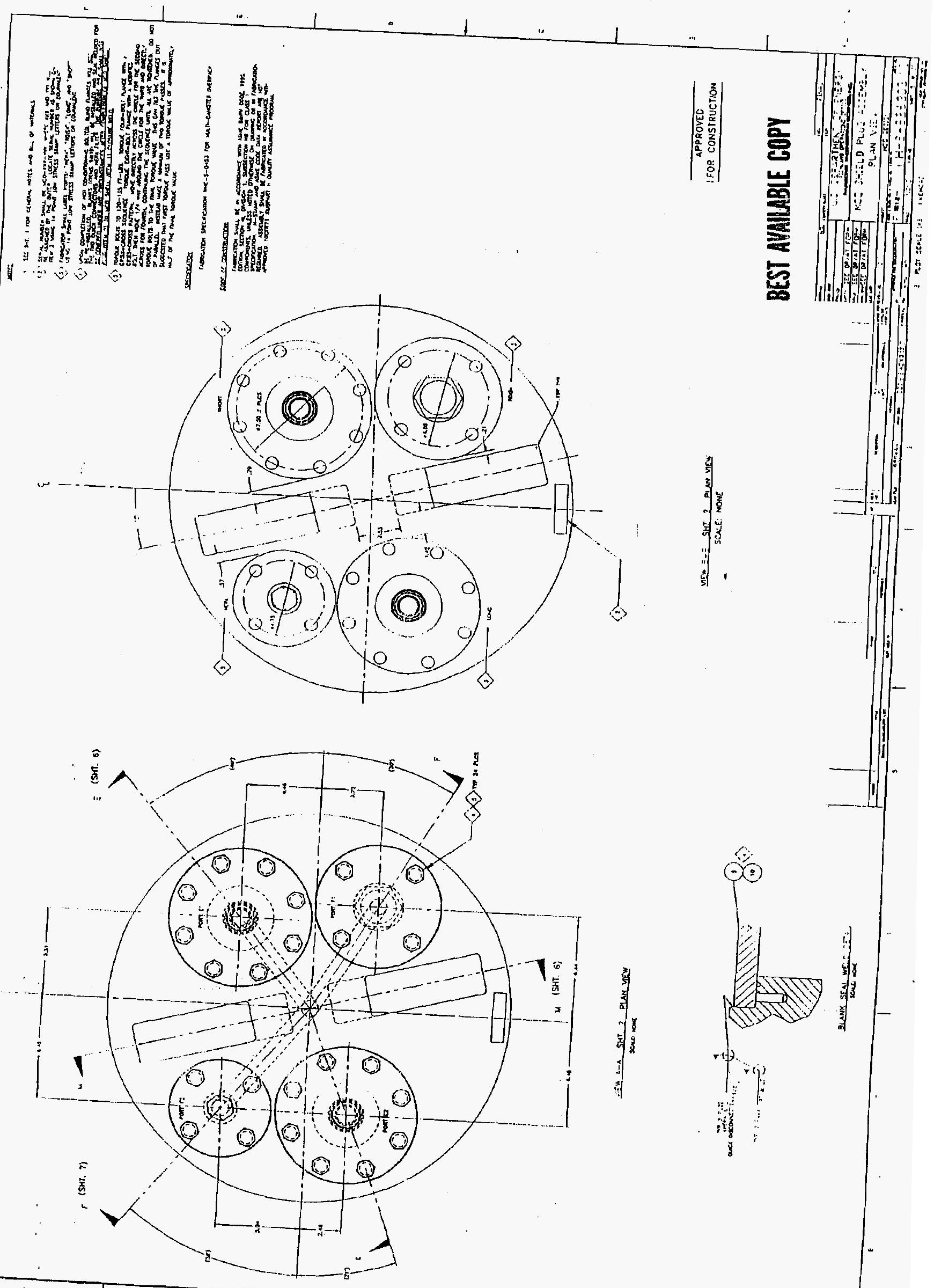

電 
THIS PAGE INTENTIONALCY

LEFT BLANK 

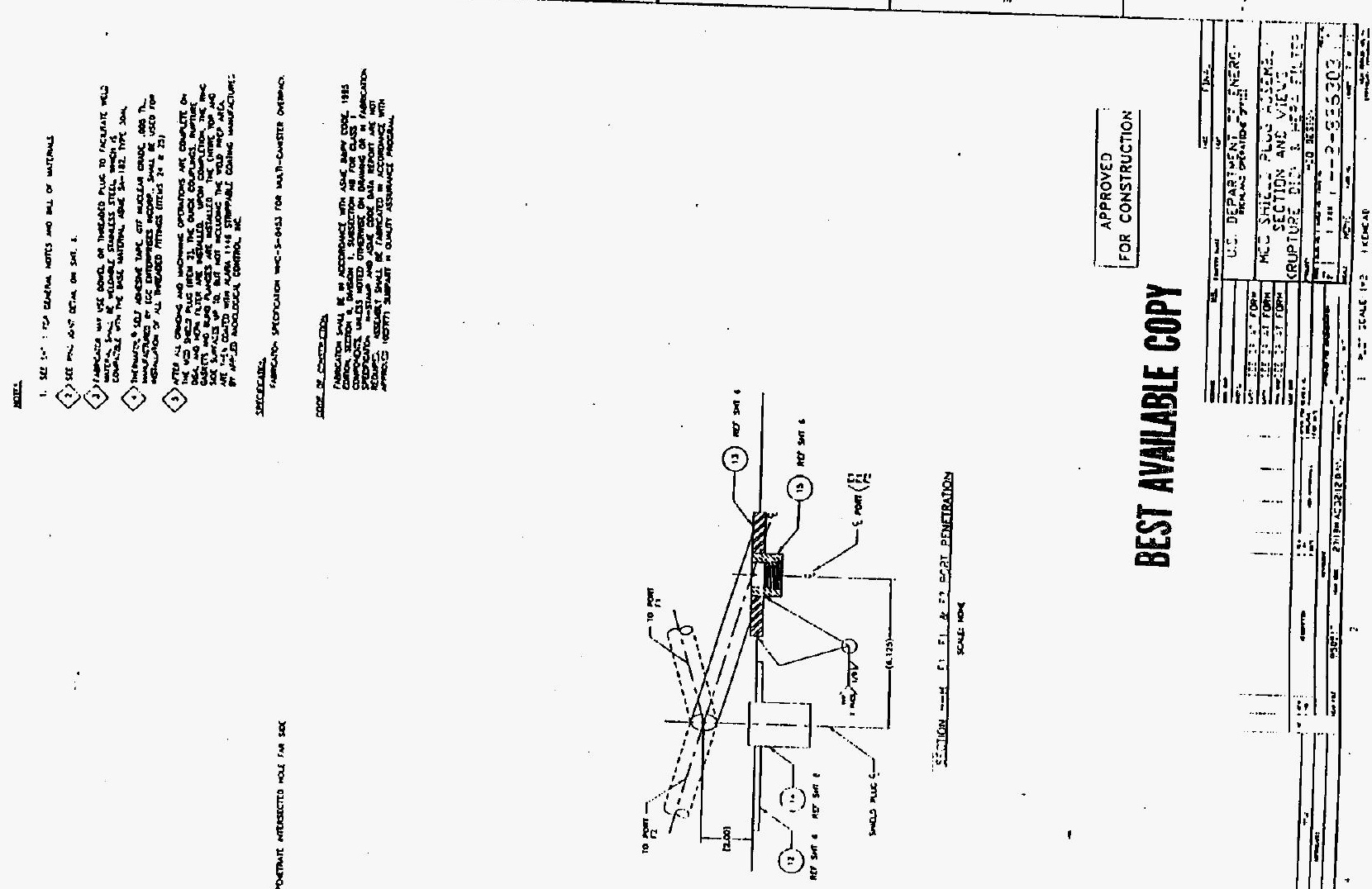

$-\infty \diamond \diamond \diamond$ मो मा

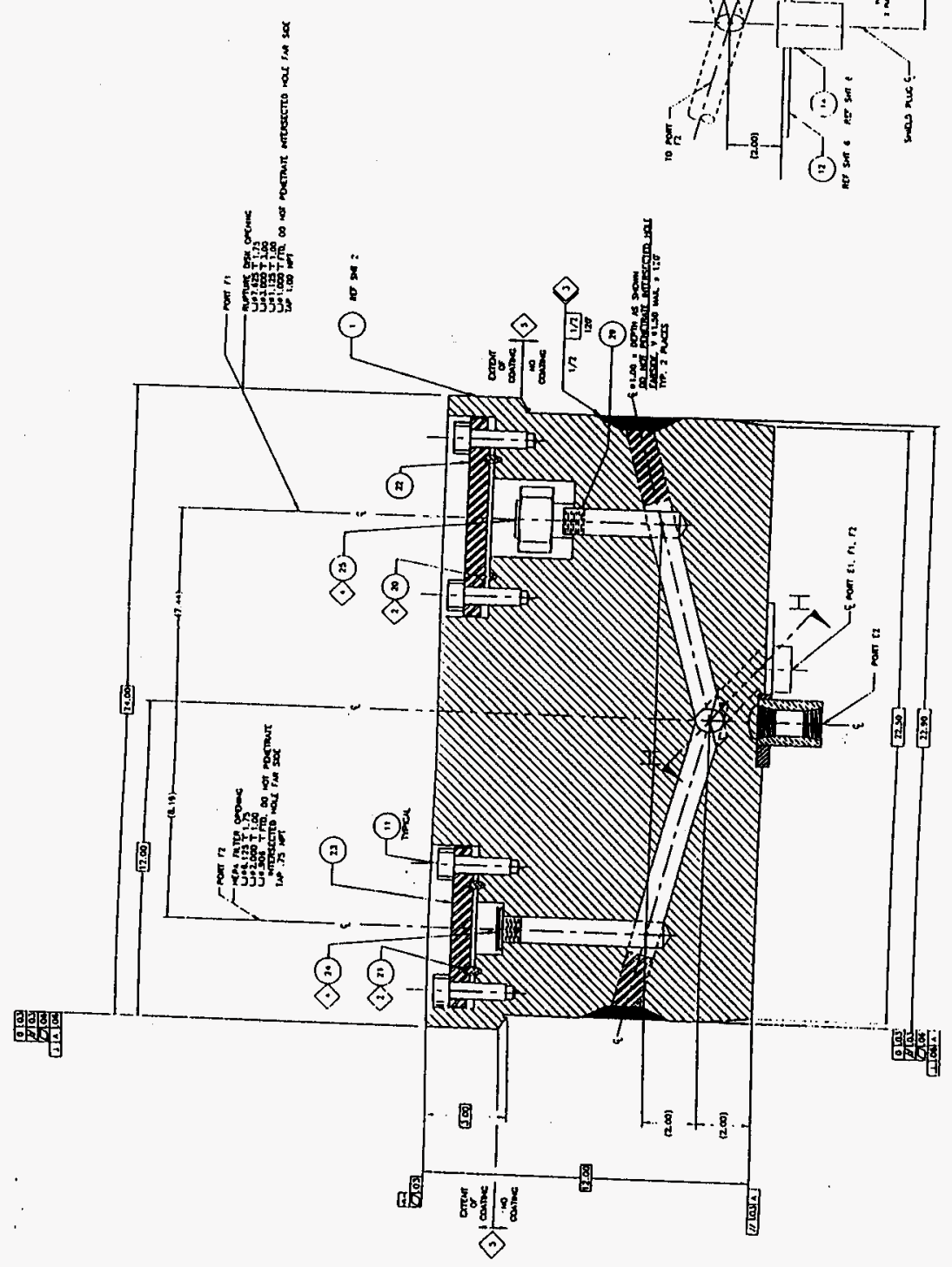


THIS PAGE NTENTIONALLY LEFT BLANK 


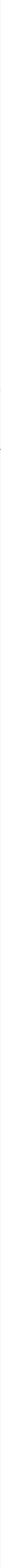


THIS PAGE INTENTIONALLY LEFT BLANK 
THIS PAGE INTENTIONALLY LEFT BLANK 


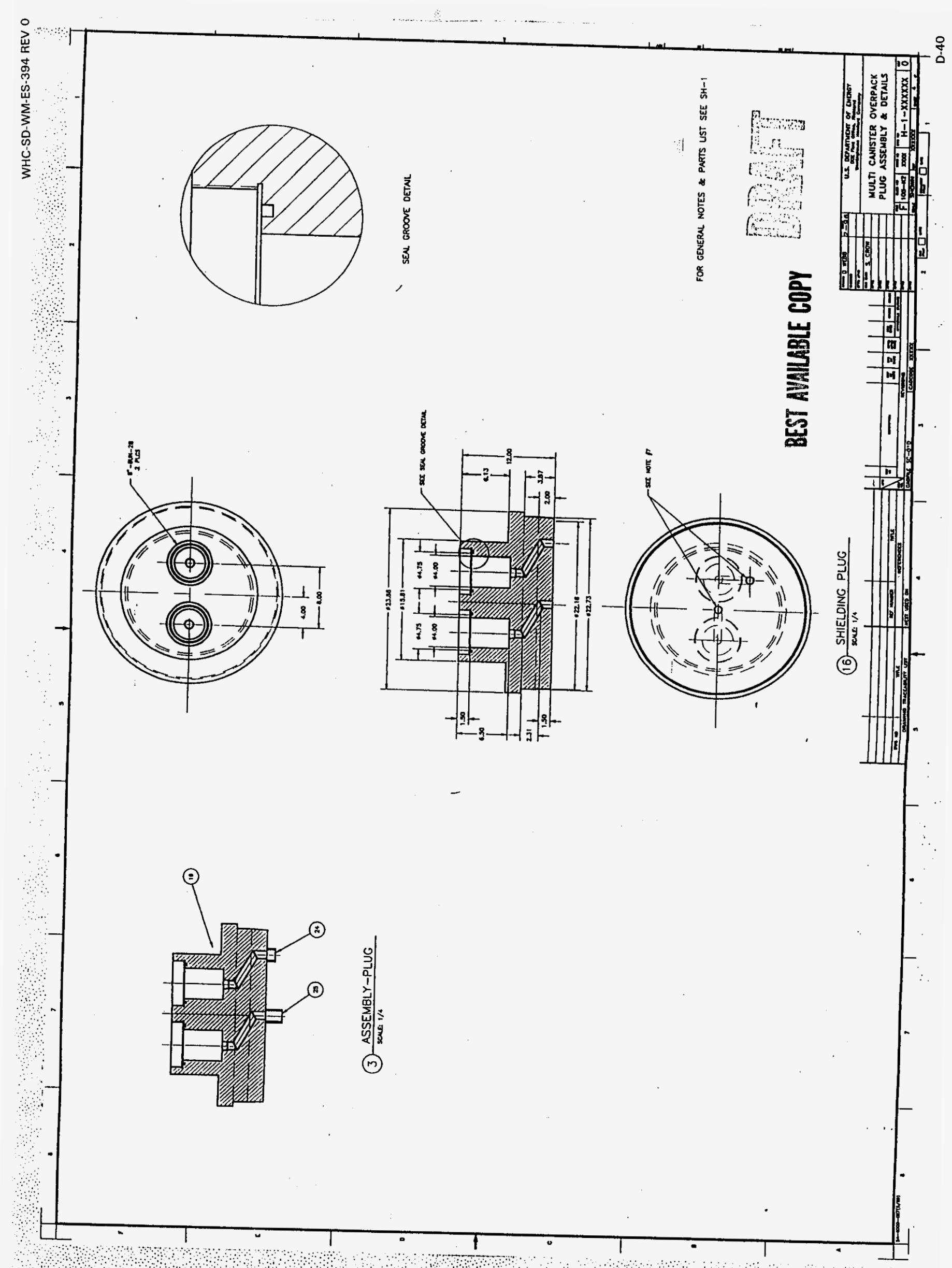


THIS PAGE INTENTIONALLY

LEFT BLANK 


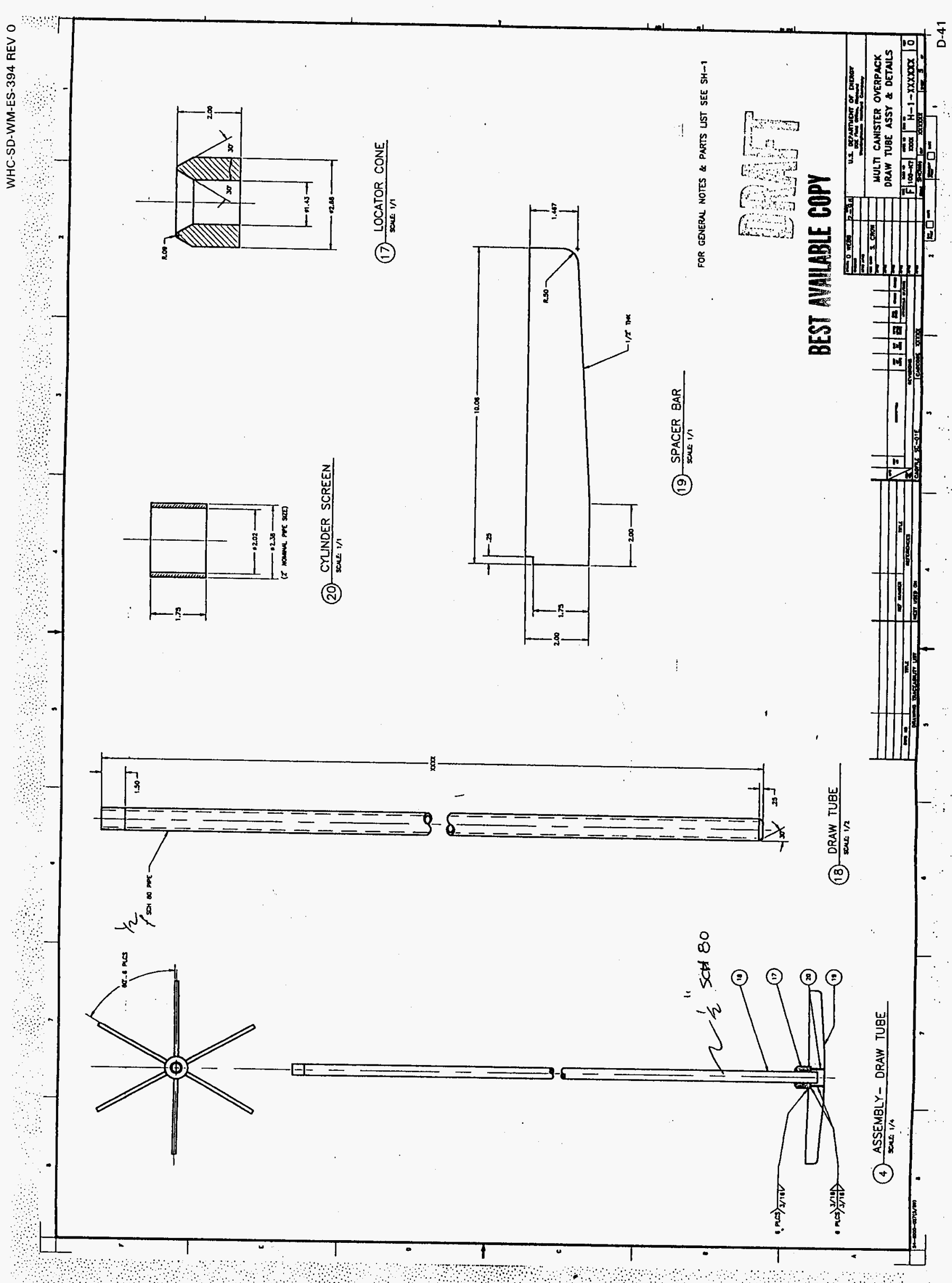


THIS PAGE INTENTIONALLY LEFT BLANK 


\section{DISTRIBUTION SHEET}

\begin{tabular}{|c|c|c|c|c|c|}
\hline \multirow{2}{*}{$\begin{array}{l}\text { To } \\
\text { Distribution }\end{array}$} & \multirow{2}{*}{\multicolumn{3}{|c|}{$\begin{array}{l}\text { From } \\
\text { T Plant Engineering }\end{array}$}} & \multicolumn{2}{|l|}{ Page 1 of 1} \\
\hline & & & & \multicolumn{2}{|c|}{ Date $9 / 26 / 96$} \\
\hline \multicolumn{3}{|l|}{ Project Title/Work Order } & & \multicolumn{2}{|c|}{ EDT No. 615201} \\
\hline \multicolumn{3}{|c|}{$\begin{array}{l}\text { Removal Plan for Shippingport Pressurized Water Reactor } \\
\text { Core 2/A33LP }\end{array}$} & & \multicolumn{2}{|l|}{ ECN No. } \\
\hline Name & MSIN & $\begin{array}{c}\text { Text } \\
\text { With All } \\
\text { Attach. }\end{array}$ & Text Only & $\begin{array}{c}\text { Attach./ } \\
\text { Appendix } \\
\text { Only }\end{array}$ & $\begin{array}{l}\text { EDT/ECN } \\
\text { Only }\end{array}$ \\
\hline A. B. Carlson (3) & R3-86 & $x$ & & & \\
\hline T. L. Erickson (2) & $T 3-28$ & $x$ & & & \\
\hline W. J. Geuther & $T 3-28$ & $x$ & & & \\
\hline R. F. Guercia (3) & $\$ 7-55$ & $x$ & & & \\
\hline R. L. McCormack & R3-86 & $x$ & & & \\
\hline D. E. McKenney & $\mathrm{T} 3-01$ & $x$ & & & \\
\hline M. S. Wright & $\mathrm{T} 3-28$ & $x$ & & & \\
\hline Central Files & $A 3-88$ & $x$ & & & \\
\hline
\end{tabular}




\section{THIS PAGE INTENTIONALLY}

LEFT BLANK 